Florida International University FIU Digital Commons

\title{
Paleoenvironmental Implications of the Indidura Formation (Cenomanian/Turonian), Northeastern Mexico: a High Resolution Stratigraphic Study
}

Fabian Duque-Botero

Florida International University

DOI: $10.25148 /$ etd.FI08081513

Follow this and additional works at: https://digitalcommons.fiu.edu/etd

\section{Recommended Citation}

Duque-Botero, Fabian, "Paleoenvironmental Implications of the Indidura Formation (Cenomanian/Turonian), Northeastern Mexico: a High Resolution Stratigraphic Study" (2006). FIU Electronic Theses and Dissertations. 46.

https://digitalcommons.fiu.edu/etd/46 


\section{CHAPTER I}

\section{INTRODUCTION}

\subsection{A Review of the mid-Cretaceous Oceanic Anoxic Events}

Quantitative and qualitative studies of Cretaceous sediments around the Tethys realm allow the reconstruction of paleoclimatic and paleoceanographic conditions present during that time (Schlanger \& Jenkyns, 1976; Jenkyns, 1980; Arthur and Premoli Silva, 1982; Arthur et al., 1990). Indeed, it has been demonstrated that the evolution of the Cretaceous oceans includes series of Oceanic Anoxic Events (OAE's) particularly well recorded in the Tethys ocean from the Early Jurassic (Borrego et al., 1996) to the Cenomanian/Turonian (C/T) boundary time (Lamolda, 1978; Lamolda and Mao, 1999). These events are characterized by widespread deposition of black shales enriched in organic matter (Jenkyns, 1980; Bralower et al., 2002). Furthermore, the mid-Cretaceous sedimentary record includes at least five OAE's (Jenkyns et al. 1994; Leckie et al., 2002), which are associated in most cases with positive $\delta^{13} \mathrm{C}$ excursions that have been documented in the tests of planktonic, benthic foraminifera, marine carbonates and organic matter.

Several mechanisms have been proposed in attempts to explain the development of these organic-rich levels with positive $\delta^{13} \mathrm{C}$ excursions, including super productivity and expansion of the marine archaea (Kuypers et al. 2001), which could have led to the ${ }^{13} \mathrm{C}$ enrichment recorded during the "mid" Cretaceous. Nonetheless, the main controlling 
factor may also be related to excessive removal of ${ }^{12} \mathrm{C}$ from the marine waters because of kinetic isotopic fractionation, and the subsequent preservation of this isotopically light ${ }^{12} \mathrm{C}$ into living tissues of marine phytoplankton, hence the increased enrichment of ${ }^{13} \mathrm{C}$ in the ocean waters, because this isotope is preferentially not incorporated into the phytoplankton (Broecker, 1974). Sequestration of marine organic matter into sediments and enhanced preservation is thus a plausible mechanism for the relative enrichment of ${ }^{13} \mathrm{C}$ observed during the mid Cretaceous.

Mechanisms related to the positive $\delta^{13} \mathrm{C}$ excursions are still poorly understood, although several hypotheses have been debated to explain such events. Perhaps the circumstances that led to such unusual environmental conditions are related to several factors specific to that time, such as: [1] The "mid" Cretaceous was a period with extreme warm temperatures "greenhouse conditions" as reported from the tests of planktonic and benthic foraminifera (Huber et al., 2002). [2] Major plate tectonic reorganization that started in the Triassic continued through the Jurassic and Cretaceous (de Graciansky et al., 1984; Olsen, 1997), thereby leading many epicontinental areas to become prone to develop restricted circulation (Jenkyns, 1980; Arthur and Premoli Silva, 1982; Arthur et al., 1990). [3] The Middle Cretaceous is known as a period of enhanced oceanic crust production associated with outpouring of massive basaltic lavas or Large Igneous Provinces (LPI) that may have enhanced the supply of nutrients into the ocean (Larson, 1991; Sinton and Duncan, 1997; Kerr, 1998). [4] Increased volcanism may have contributed to an increase of atmospheric carbon dioxide believed to have been three to twelve (3-12) times higher than at present (Berner, 1992). [5] Increased atmospheric 
$\mathrm{CO}_{2}$ is hypothesized to have helped raise the already elevated sea level by further intensifying greenhouse conditions and creating an "ice free" world (Gale et al. 2002).

The combined effects of these different factors led to unusual environmental conditions in the overall structure of the surface and deep waters at that time, and particularly on the overall dissolved oxygen content, as inferred from the worldwide deposition of organicrich deposits (Jenkyns et al. 1994).

The present work covers the time interval of the Cenomanian/Turonian boundary associated with oceanic anoxic event number two (OAE-2). The sedimentary record of OAE-2 shows that perturbations that affected both existing deep-sea, and epicontinental environments were by far the most extensive, thus they are widely used as models to further our understanding of other mid-Cretaceous OAE's (Wignall, 1994). OAE-2 is also coincident with the extinction of numerous marine taxa e.g. mollusks and planktonic foraminifera (Harries and Kauffman, 1990; Leckie et al., 2002).

Northeastern Mexico sedimentary record shows that environmental conditions remained relatively constant as seen by the evidence of long lasting deposition of carbonate rich facies in a shallow epicontinental sea that covered the area since the Jurassic up to the Cretaceous. The sequence of the Indidura Formation at Parras de La Fuente also shows the overall trend of enriched organic matter in the rock sequence. As noted previously, both epicontinental seas and deep oceanic basins where affected by OAE's, but at Parras de La Fuente the lithologic characteristics indicate that conditions prone to organic 
carbon enrichment lasted about 4 million years. This dissertation therefore explores the link between the mechanisms behind the formation of organic-rich deposits and the factors that may have controlled the productivity and preservation of such materials in the sedimentary record of the Indidura Formation in the section at Parras de la Fuente.

\subsection{Productivity or Preservation, the models behind mid-Cretaceous black shales}

Preservation and/or productivity models have often been invoked to explain the widespread accumulation of organic-rich rocks during the Cretaceous.

The productivity model argues in favor of enhanced primary productivity that overcomes oxidation of organic matter OM (remineralization) through the water column. In presentday environments productivity is primarily controlled by upwelling of deep waters rich in biolimiting nutrients into well-oxygenated surface waters. Overabundance of organic matter produced at the surface and their export to the subsurface, where decay takes place causes an expansion and intensification of the oxygen minimum zone (OMZ) into the shelves, while the bottom waters may remain well oxygenated (Wilde and Berry, 1982; Wyrtki, 1962). In the case of the mid-Cretaceous events, several factors appear to have been conducive to intensify productivity during that time: strong vertical mixingupwelling supplemented by input of nutrients from rivers (Erbacher et al., 1996); increased volcanic activity (Sinton and Duncan, 1997; and Kerr, 1998). This model has been mainly applied to the Cretaceous Pacific Ocean where anoxia did not reach the deepest waters (Schlanger and Jenkyns, 1976). 
The preservation model on the other hand is based on a decrease of OM remineralization because of diminishing oxygen flux at the water-sediment interface. In present-day oceans perennial anoxic conditions favorable to OM preservation only occur in restricted areas of the ocean where basins are isolated to circulation of oxygenated deep waters e.g. Cariaco Basin (Yarincik et al., 2000). Based on Cretaceous paleoceanographic models, Barron (1983) suggested that minimal equator to pole thermal gradients should result in a decrease in the formation of oxygen-rich bottom waters. In addition, it has also been suggested that a thermohaline circulation mode of subtropical oxygen-poor warm deep waters was likely for the mid-Cretaceous ocean (Hay, 1988). Molecular chemical fossils or "biomarkers" found in C/T OAE2 bring corroborative evidence in support of such mechanisms as they suggest the presence of anoxygenic photosynthetic bacteria in deepsea sediments, which implies that anoxic conditions extended into the photic zone (Sinninghe Damste and Koster, 1998; Rau et al., 1987; Kuypers et al., 2004). These authors also found that $\mathrm{N}_{2}$ fixing cyanobacteria and archaea dominated the phytoplankton communities during the early to mid-Cretaceous.

\subsection{Methodology of the present work}

Based on current knowledge of factors that may control C-org-rich sediments, the present study of the Indidura Formation at Parras is the first attempt to unravel these relationships in the northeastern Mexican basin. Thus, through the use of petrography, geochemistry and biostratigraphy this study will further our understanding of the prevailing environmental and depositional conditions for northeastern Mexico as well as the 
sedimentary cycles and $\mathrm{C}_{\text {org }}$-rich events in the Indidura Formation. These findings may also be relevant to other sites elsewhere worldwide.

\section{$1.4 \quad$ Summary}

In chapters 2, 3 and 4 I present a general picture of the geology, stratigraphy and methodology used for the development of this research.

In chapter 5, I describe the stratigraphic sequence found at Parras de la Fuente, which is the main site used for detailed analyses that form the framework of this research.

Chapter 6 is a published article (Duque-Botero and Maurrasse, Journal of Iberian Geology, 2005), which recapitulates the concept of the Indidura Formation in terms of its sedimentologic and petrographic content. Rock sequences from the area that have been placed under the name Indidura Formation are compared in three areas in terms of their petrographic, $\mathrm{TOC} / \mathrm{CaCO}_{3}$ content and primary sedimentary structures, which revealed the facies changes present in the basin. The paper also shows for the first time the presence of cyanobacterial calcareous microspheroids as a primary component of the sedimentary sequence of the Indidura Formation near Parras de la Fuente. These sediments indicate environments at Parras where such that the primary laminae are perfectly preserved and benthic fossils are almost absent throughout the sequence.

The sedimentary sequences at the other sections of Las Delicias and La Casita show prevailing paleoenvironments with abundant benthic epifauna, planktonic and nektonic organisms, which contrast sharply with that found in the Sierra de Parras. 
Chapter 7 is an article submitted to Cretaceous Research (Duque-Botero and Maurrasse, submitted Dec. 2005, and accepted for publication, May 2006), which shows that the stratigraphic sequence found at Parras de la Fuente has well-defined rhythms at the decimetric to millimetric scales. Compositional differences found in the laminae are associated with varying abundance of microspheroids $(20-40 \mu \mathrm{m}$ in diameter) of cyanobacterial origin (Duque-Botero and Maurrasse, 2005). These results also show a direct correlation between the abundance of the cyanobacterial remains, the type of laminae present in the sediments, and the varying composition of the rock, as seen in the TOC and Carbonate contents. Laminae developed from varying magnitude of cyanobacterial blooms that prevailed throughout the unit. These facies imply unique paleogeographic and paleoceanic conditions that enhanced the intervening factors in the environment throughout deposition of the Indidura Formation at Parras de La Fuente.

Chapter 8 is an article submitted to the Society of Sedimentary Petrology Special Publication (Duque-Botero et al., submitted March 2006), which gives further supporting geochemical evidence of the paleoceanographic and paleogeochemical changes that took place during the deposition of the Indidura Formation. High values recorded for certain elements $(\mathrm{Mo}, \mathrm{V}$, and $\mathrm{Cr}$ ), further concur with the petrographic and SEM analyses that the sequence at Parras accumulated under dysoxic to anoxic conditions in which microbial communities were predominant. Stable isotope analyses and micropaleontologic nannofossil data allow for more accurate biostratigraphic positioning of the Parras sequence within the Upper Cenomanian CC10 zone through the Middle Turonian CC13 zone. These data thus substantiate that long lasting unusual conditions 
prevailed in that basin, and that the upper water masses where connected with the open ocean. The results show as well that the stable isotopes anomalies found elsewhere during the time span of the $\mathrm{C} / \mathrm{T}$ boundary event are present in the sediments of the Indidura Formation at Parras de La Fuente.

Chapter 9 is an article submitted to Earth and Planetarium Science Letters (DuqueBotero et al., sub. June 2006), which presents evidence on the origin of the paleoclimatic variations that acted as controlling mechanism during the deposition of the sedimentary sequence of the Indidura Formation. Continuous wavelet analysis (CWA) of laminae counts and grayscale of digital images shows that the stratigraphic sequence was affected by paleoclimatic forcing related to frequencies in the range of the Schwabe solar-cycles, indicating that the alternation of cyanobacterial microspheroid rich and poor laminae where the product of perennial blooms related to possible enhanced runoff. CWA of TOC and $\mathrm{CaCO} 3$ shows that quasi-periodic interbeds of the Indidura Formation formed at a periodicity of about $20 \mathrm{ka}$ (Precession cycle). Such variations may imply shift in trends of pluviosity that generated conditions favorable to sustained blooms of cyanobacteriainduced calcareous microspheroids. High bacterial productivity further decreased the oxygen levels and helped maintain dysoxic/anoxic waters, as recorded in these sediments over more than four million years. 


\subsection{References}

Arthur, M.A., Jenkyns, H.C., Brumsack, H.J., and Schlanger, S.O., 1990, Stratigraphy, geochemistry, and paleo-oceanography of organic carbon-rich Cretaceous sequences, in Ginsburg, R.N. and Beaudoin, B., eds., Cretaceous resources, events and rhythms; background and plans for research: Dordrecht-Boston, D. Reidel Publishing Company, p. 75-119.

Arthur, M.A. and Premoli Silva, I., 1982, Development of widespread organic carbonrich strata in the Mediterranean Tethys, in Schlanger, S.O. and Cita, M.B., eds., Nature and origin of Cretaceous carbon-rich facies: London, Academic Press Inc., p. 7-54.

Barron, E.S., 1983, A warm, equable Cretaceous; the nature of the problem: EarthScience Reviews, v. 19, p. 305-338.

Berner, R.A., 1992, Palaeo- $\mathrm{CO}_{2}$ and climate; discussion: Nature, v. 358, p. 114, 09.

Borrego, A.G., Hagemann, H.W., Blanco, C.G., Valenzuela, M., and Suarez de Centi, C., 1996, The Pliensbachian (Early Jurassic) "anoxic" event in Asturias, northern Spain; Santa Mera Member, Rodiles Formation: Organic Geochemistry, v. 25, p. 295-305.

Bralower, T.J., Premoli Silva, I., Malone, M.J., et al., 2002, Shipboard Scientific Party. Proceedings ODP, Initial Reports, 198: 1-84. Available from World Wide Web: http://www-odp.tamu.edu/publications/198 IR/198ir.htm.

Broecker, W.S., 1974, Chemical Oceanography: New York, N. Y., Harcourt Brace Jovanovich, Inc, p. -214.

de Graciansky, P.C., Deroo, G., Herbin, J.P., Montadert, L., Mueller, C., Schaaf, A., and Sigal, J., 1984, Ocean-wide stagnation episode in the Late Cretaceous: Nature, v. 308, p. 346-349.

Duque-Botero, F. and Maurrasse, F.J.-M.R., 2005, Cyanobacterial productivity, variations in the organic matter and facies of the Indidura Formation (Cenomanian-Turonian), Northeastern Mexico: Journal of Iberian Geology, v. 31, p. $87-100$.

Erbacher, J., Thurow, J., and Littke, R., 1996, Evolution patterns of radiolaria and organic matter variations; a new approach to identify sea-level changes in MidCretaceous pelagic environments: Geology, v. 24, p. 499-502.

Gale, A.S., Hardenbol, J., Hathway, B., James Kennedy, W., Young, J.R., and Phansalkar, V., 2002, Global correlation of Cenomanian (Upper Cretaceous) 
sequences: Evidence for Milankovitch control on sea level: Geology, v. 30, p. 291-294.

Harries, P.J. and Kauffman, E.G., 1990, Patterns of survival and recovery following the Cenomanian-Turonian (Late Cretaceous) mass extinction in the Western Interior Basin, United States, in Kauffman, E.G. and Walliser, O.H., eds., Extinction events in earth history. Lecture Notes in Earth Sciences 30: Berlin, SpringerVerlag, p. 277-298.

Hay, W.W., 1988, Paleoceanography; a review for the GSA Centennial: Geological Society of America Bulletin, v. 100, p. 1934-1956.

Huber, B.T., Norris, R.D., and MacLeod, K.G., 2002, Deep-sea paleotemperature record of extreme warmth during the Cretaceous: Geology, v. 30, p. 123-126.

Jenkyns, H.C., 1980, Cretaceous anoxic events; from continents to oceans: Journal of the Geological Society of London, v. 137, p. 171-188.

Jenkyns, H.C., Gale, A.S., and Corfield, R.M., 1994, Carbon- and oxygen-isotope stratigraphy of the English Chalk and Italian Scaglia and its palaeoclimatic significance: Geological Magazine, v. 131, p. 1-34.

Kerr, A.C., 1998, Oceanic plateau formation: a cause of mass extinction and black shale deposition around the Cenomanian-Turonian boundary?: Journal of the Geological Society, v. 155, p. 619-626.

Kuypers, M.M.M., Blokker, P., Erbacher, J., Kinkel, H., Pancost, R.D., Schouten, S., and Sinninghe Damste, J.S., 2001, Massive Expansion of Marine Archaea During a Mid-Cretaceous Oceanic Anoxic Event: Science, v. 293, p. 92-95.

Kuypers, M.M.M., van Breugel, Y., Schouten, S., Erba, E., and Sinninghe Damste, J.S., 2004, $\mathrm{N}_{2}$-fixing cyanobacteria supplied nutrient $\mathrm{N}$ for Cretaceous oceanic anoxic events: Geology, v. 32, p. 853-856.

Lamolda, M.A., 1978, Le passage Cenomanien-Turonien dans la coupe de Menoyo (Alaya, Alava). The Cenomanian-Turonian boundary in the Menoyo Section; Alaya, Alava: Cahiers de Micropaleontologie, p. 21-27.

Lamolda, M.A. and Mao, S., 1999, The Cenomanian-Turonian boundary event and dinocyst record at Ganuza (northern Spain): Palaeogeography, Palaeoclimatology, Palaeoecology, v. 150, p. 65-82.

Larson, R.L., 1991, Geological consequences of superplumes: Geology, v. 19, p. 963966. 
Leckie, R.M., Bralower, T.J., and Cashman, R., 2002, Oceanic anoxic events and plankton evolution: Biotic response to tectonic forcing during the midCretaceous: Paleoceanography, v. 17, p. 29.

Olsen, P.E., 1997, Stratigraphic record of the early Mesozoic breakup of Pangea in the Laurasia-Gondwana rift system: Annual Review of Earth and Planetary Sciences, v. 25, p. $337-401$.

Rau, G.H., Arthur, M.A., and Dean, W.E., 1987, ${ }^{15} \mathrm{~N} /{ }^{14} \mathrm{~N}$ variations in Cretaceous Atlantic sedimentary sequences: implication for past changes in marine nitrogen biogeochemistry: Earth and Planetary Science Letters, v. 82, p. 269-279.

Schlanger, S.O. and Jenkyns, H.C., 1976, Cretaceous oceanic anoxic events; causes and consequences: Geologie en Mijnbouw, v. 55, p. 179-184.

Sinninghe Damste, J.S. and Koster, J., 1998, A euxinic southern North Atlantic Ocean during the Cenomanian/Turonian oceanic anoxic event: Earth and Planetary Science Letters, v. 158, p. 165-173.

Sinton, C.W. and Duncan, R.A., 1997, Potential links between ocean plateau volcanism and global ocean anoxia at the Cenomanian-Turonian boundary: Economic Geology, v. 92, p. 836-842.

Wignall, P.B., 1994, Black shales: Oxford University Press, p. 127.

Wilde, P. and Berry, W.B.N., 1982, Progressive ventilation of the oceans; potential for return to anoxic conditions in the post-Paleozoic, in Schlanger, S.O. and Cita, M.B., eds., Nature and origin of Cretaceous carbon-rich facies: New York, Academic Press, p. 209-224.

Wyrtki, K., 1962, The oxygen minima in relation to ocean circulation: Deep-Sea Research, v. 9, p. 11-23.

Yarincik, K.M., Murray, R.W., Lyons, T.W., Peterson, L.C., and Haug, G.H., 2000, Oxygenation history of bottom waters in the Cariaco Basin, Venezuela, over the past 578,000 years: results from redox-sensitive metals (Mo, V, Mn, and Fe): Paleoceanography, v. 15, p. 593-604. 


\section{CHAPTER II}

\section{GEOGRAPHIC AND GEOLOGIC SETTING}

The study area is located in the broad geographic zone commonly referred to as northeastern Mexico, which comprises the states of Nuevo Leon, Coahuila de Zaragoza, Chihuahua, Tamaulipas (Figure 2- 1). The region is bounded on the north by the United States of America, on the south by the Sierra Madre Oriental and the coastal plain of the northern Gulf of Mexico, on the east by the Gulf of Mexico, and on the west by the Sierra Madre Oriental.

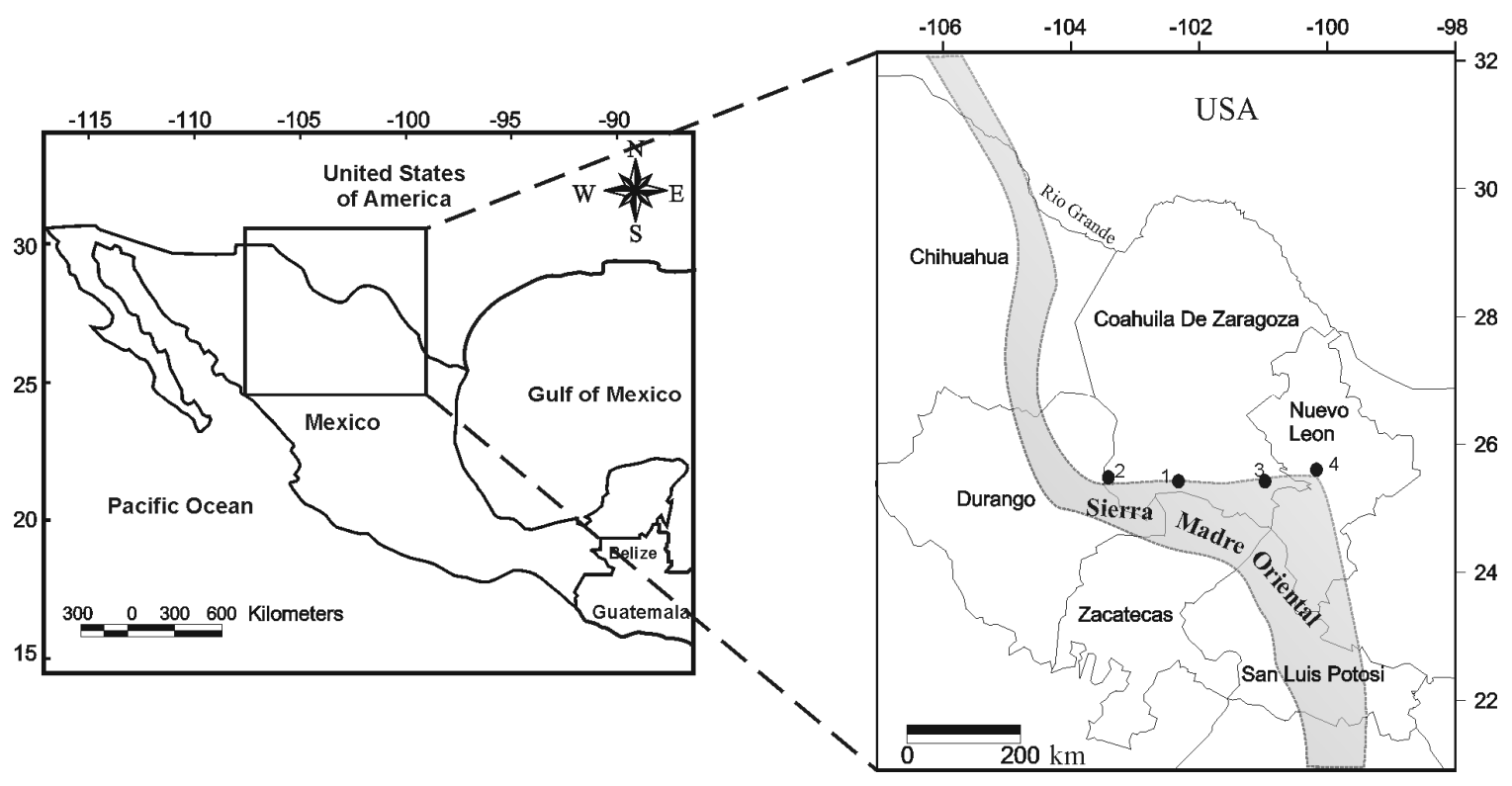

Figure 2- 1. Geographic map of northeastern Mexico. 1=Parras de la Fuente; $2=$ Torreon; $3=$ Saltillo; 4=Monterrey

The overall climate is typically arid to semi-arid in the western, northern and central parts, while the Sierra Madre Oriental and the Gulf of Mexico are humid to sub-humid. Temperature ranges from hot to warm during the summer and warm to cold during the 
winter (Moran-Zenteno, 1994). Overall dry conditions together with summer rains created excellent rock exposures along streams and dry gullies (Lopez-Ramos and Guerrero, 1981).

The study site is in the Sierra de Parras, which is at the southernmost part of the Mexican highland that extends from the Rio Grande south, west of Saltillo and Torreon. These mountains extend into the plains creating finger-like structures that are the remnant of ancient and active alluvial fans. The plains rise to about 1000 to 1500 meters above sea level, whereas the mountains reach from about 500 to 1200 meters above the plains. The Sierra de Parras forms the western part of the Sierra Madre Oriental Transverse where rock outcrops range from the Paleozoic to the Cenozoic, including a thick Mesozoic sedimentary sequence. Some volcanic cones and flows and intrusions are also found in these mountains, especially near the area of Las Delicias (INEGI, 1988).

Structurally, the northern portion of the Sierra Madre Oriental forms the Sierra Transverse and runs nearly east to west between Monterrey and Torreon. It is the northern expression of a thrust and fold belt considered as the southern extension of the western North American Cordillera (Tardy et al., 1975; Padilla y Sanchez, 1985; Quintero-Legorreta and Aranda-Garcia, 1985). In the Monterrey area the Sierra Madre Oriental changes direction toward the southeast (Figure 2.1) toward Tampico. The structural development of the Sierra Transverse is related to both salt tectonics and preexisting basement structures that appear to have controlled the extent of the Laramide deformational styles (Gray and Johnson, 1995; Tardy et al., 1975). 


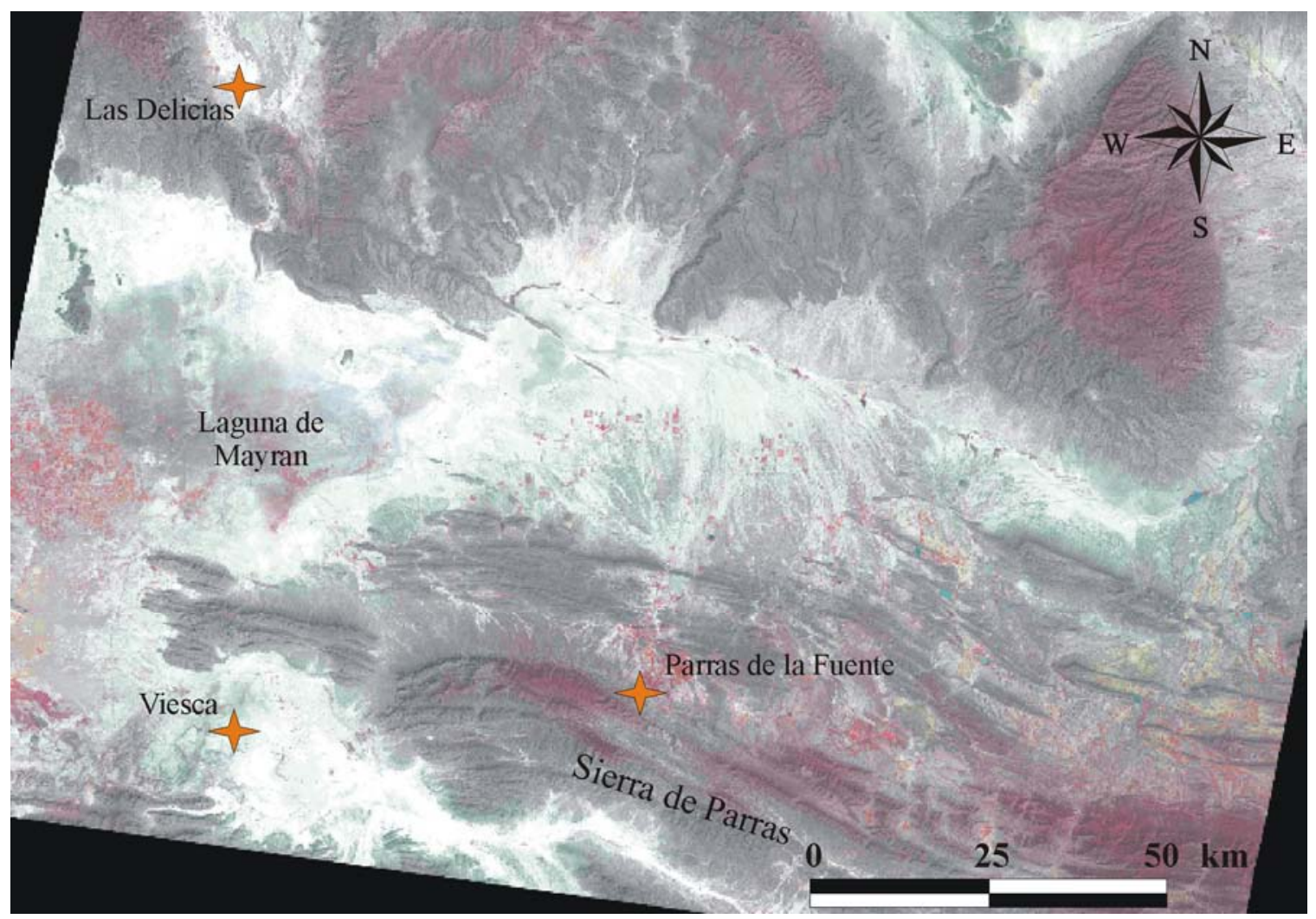

Figure 2- 2. Landsat 7 (bands 4-3-2) image of Central Coahuila state. Box marks the area near Parras de la Fuente, site of the present study. Main structural trend runs east-west. Mesozoic sediments are exposed in the Southern part of the area. Cenozoic alluvial and lake deposits of the Laguna de Mayran and Parras Basin cover most of the central area.

The present study investigates a Cenomanian-Turonian stratigraphic sequence in the Sierra de Parras, 2 kilometers west of the town of Parras de La Fuente in Coahuila State (Figure 2-2). The overall structure of the area consists of tight anticlinal folds and thrust with vergence toward the NE (Tardy, 1975). The Indidura Formation in this thrust zone is limited to the external part of the belt, including recumbent folds in the vicinity of Viesca, and usually appears in faulted contact with the Cupido Formation. Some intervals of the Indidura show strong shear development "schistosity" and microfolding, all these relationships are well observed and particularly well developed toward the Viesca area. In the Parras de La Fuente area folds have broader, less recumbent structures, and the 
contact with other underlying unit is concordant (Tardy et al., 1975; Padilla y Sanchez, 1982; INEGI, 1988). 


\subsection{References}

Gray, G.G. and Johnson, C.A. 1995, Structural and Tectonic Evolution of the Sierra Madre Oriental with Emphasis on the Saltillo-Monterrey Corridor, AAPG Annual Convention, Field trip excursion, p. 1-17.

INEGI, 1988, Carta Geológica Torreón, Instituto Nacional de Estadística Geografía e Informática: Hoja G13-9, Scale 1:25.000, 1 sheet.

Lopez-Ramos, E. and Guerrero, J.C., 1981, Paleogeografia y tectonica del Mesozoico de Mexico. Paleogeography and tectonics of the Mesozoic in Mexico: Revista Instituto de Geologia, v. 5, p. 158-177.

Moran-Zenteno, D., 1994, Geology of the Mexican Republic, Tulsa, American Association of Petroleum Geologists, $160 \mathrm{p}$.

Padilla y Sanchez, R. J., 1985, Las estructuras de la Curvatura de Monterrey, estados de Coahuila, Nuevo León, Zacatecas y San Luís Potosí. The structures of the Monterrey Arc; Coahuila, Nuevo Leon, Zacatecas, and San Luis Potosí, Revista Instituto de Gología, vol.6, no.1, p.1-20.

Quintero-Legorreta, O. and Aranda-Garcia, M., 1985, Relaciones estructurales entre el Anticlinorio de Parras y el Anticlinorio de Arteaga (Sierra Madre Oriental), en la región de Agua Nueva, Coahuila. Structural relations in the Parras and Arteaga anticlinoria (Sierra Madre Oriental), in the region of Agua Nueva, Coahuila, Revista Instituto de Geologia, vol.6, no.1, p.21-36.

Tardy, M., Longoria, J. F., Martinez-Reyes, J., Mitre S. L. M., Patiño A. M., Padilla y Sanches, R., Ramirez, C., 1975, General observations on the structure of the eastern Sierra Madre; the allochthon of the central Alta-Altiplano Chain, between Torreón, Coahuila and San Luis Potosi, Mexico, Revista - Instituto de Geología, no.1, p. 1-11. 


\section{CHAPTER III}

\section{STRATIGRAPHIC FRAMEWORK}

\subsection{General Stratigraphy}

The Cretaceous sedimentary sequences of northeastern Mexico have been generally grouped as a series of time equivalent stratigraphic units, named from oldest to youngest, Coahuilan, Comanchean and Gulfian series (Bishop, 1970). They indicate that the opening of the proto-Atlantic allowed the development of open marine connections with the Tethys, and epicontinental seas became established in the northeastern areas of present Mexico. These epicontinental seas were continually flooded as early as the Late Jurassic, and continued through the Cretaceous. This setting permitted the deposition of an almost continuous carbonate-rich sequence (Moran-Zenteno, 1994) and the dispersal of Tethyan and South American Biota in these areas by the Early Cretaceous

\subsubsection{The Coahuilan Series}

The name "Coahuila Group" was originally introduced by Imlay (1940) and referred to the Lower Cretaceous units that include the ammonite zone of Dufrenoyia texana sensu Imlay (op cit.) In the study area, the Coahuilan series is composed of three lithostratigraphic units named as the Taraises Formation, the Lower Tamaulipas Formation and the Cupido Formation. Humprey (1949) and Forgotson (1957) redefined the Coahuilan-Comanchean boundary to coincide with the onset of the base of La Peña 
Formation, thus making the boundary to correlate with a definite lithostratigraphic change.

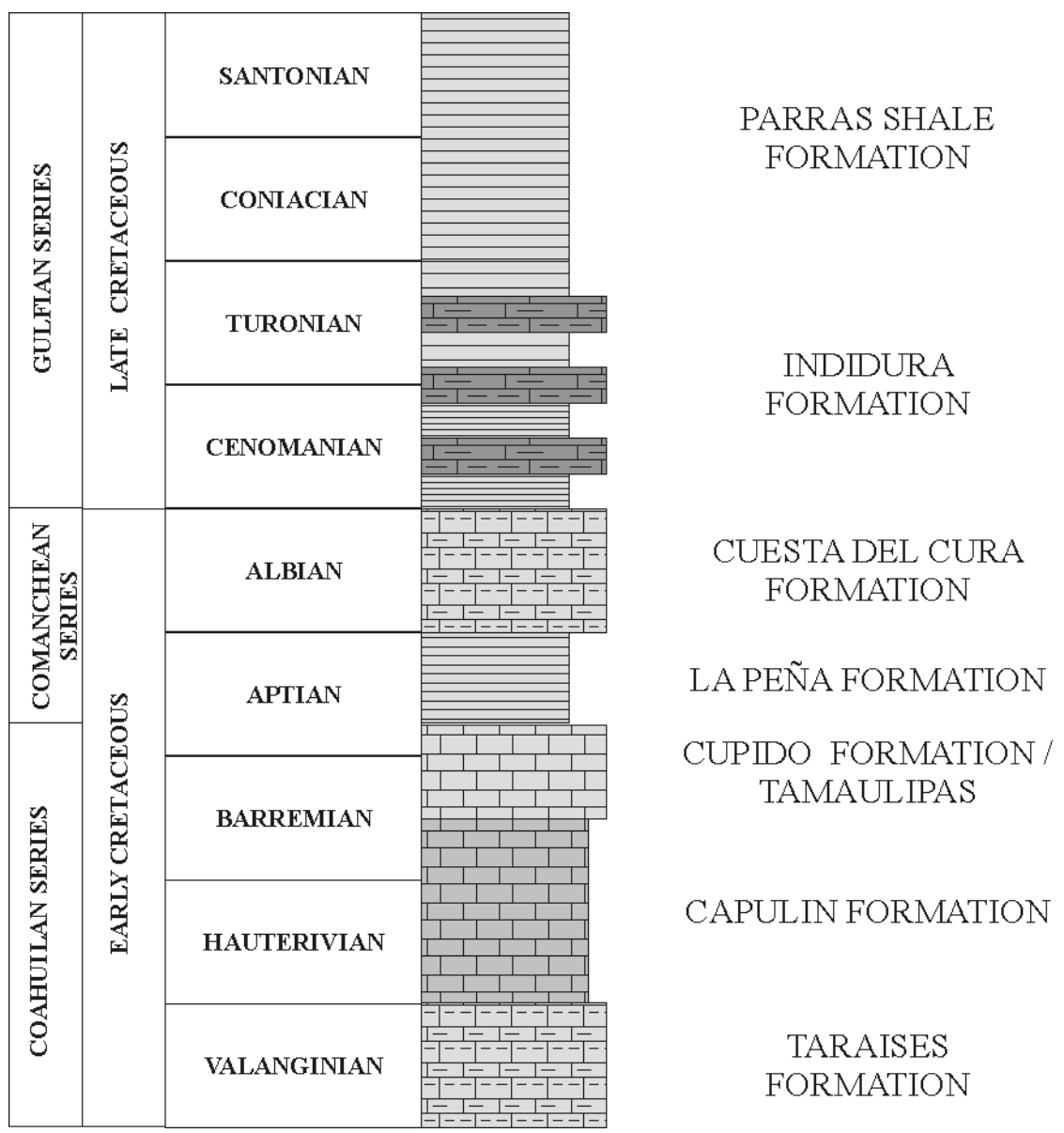

Figure 3- 1. Schematic generalized stratigraphic section of units outcropping near the Sierra de Parras. Nomenclature and ages follow the works of Imlay $(1936,1937,1940)$ and Bishop (1970). Units are not drawn to scale due to areal thickness variations.

\subsubsection{Comanchean Series}

The term was first used by Hill (1887) to define a sequence of Lower Cretaceous strata of central Texas, which also correlate with the following northeastern Mexico lithostratigraphic units: La Peña, Upper Tamaulipas, Aurora and Cuesta del Cura. Bishop 
(1970) defined the upper limit as the base of the Gulfian Series beginning on the top of the Cuesta del Cura Formation.

\subsubsection{Gulfian Series}

The term was introduced by Hill (1887) to all the Cretaceous rocks of Texas that unconformably lie above the Comanchean Series. These deposits are the youngest sedimentary units of the Cretaceous System of northeastern Mexico (Bishop, 1970). In northeastern Mexico, it includes the lithostratigraphic units of the Indidura, the Agua Nueva, and the San Felipe Formations, the Mendez and Parras shales, and the Difunta Group.

\subsection{Brief Nomenclature history of the Cretaceous units outcropping on the Sierra de Parras with emphasis on the Indidura Formation}

The stratigraphy of the Sierra de Parras near the town of Parras de la Fuente (Figure 3- 1) consists predominately of carbonate-rich units; from older to younger the units are the following.

The Valanginian Taraises Formation, is composed of calcareous shales and limestones, with levels rich in mollusks (Imlay, 1936). The Capulin Formation, (Humphrey and Diaz (2003) formerly referred to as Las Vigas Formation by Imlay (1936) who followed the work of Burrows (1910). The Capulin Formation is composed of fine- to medium- 
grained brown to yellowish brown calcareous sandstones and siliceous shaly, somewhat sandy limestones (Humphrey and Diaz, 2003). No diagnostic fossils have been found in the formation; nonetheless, based on its stratigraphic position, it may lie between the late Hauterivian and the early Barremian (Imlay, 1936; Humphrey and Diaz, 2003). The Cupido Formation (Imlay, 1937; Humphrey, 1949), overlies the Capulin Formation, and consists of dark gray to black massive limestones with rudists of Barremian age. During the Barremian to Aptian a distinctive facies accumulated toward the western part of the platform, and is known as the Tamaulipas Formation (Ross et al., 1981). It is composed of limestones and marls with fossils characteristic of deeper-water environments than those of the Cupido Formation. The La Peña Formation (Imlay, 1936; Humphrey, 1949) overlies the Cupido limestones and comprises marl/shale facies with abundant ammonites of Aptian age. The Aurora limestone (Imlay, 1940), overlies the La Peña Formation, and is composed of gray limestone beds that grade into thinly-bedded shaly limestones. Overlying the Aurora is the Cuesta del Cura Formation (Imlay, 1936, 1937), which is composed of gray shales and limestones with numerous chert stringers, and was assigned a late Albian age.

Kelly (1936 p. 1028-1029) defined the Indidura Formation, from outcrops at Las Delicias area, as composed in its lower part of "...imperfectly consolidated buff shales containing many crystals of selenite. A thin transitional zone of intercalated platy limestone and shale is included with the Indidura. The highest beds observed are imperfectly stratified buff shales containing numerous veinlets of selenite"; and he further added that "...the 
formation is about 100 feet thick and is divisible in three parts. The lower and upper divisions include the shale beds already mentioned. The middle division consists of interbedded rubbly, gray, pink and red argillaceous limestones, platy limestones and calcareous shale. Some fossils were collected from the lower division, but they are more numerous in the middle, where there are some fossiliferous horizons. Echinoidea, pelecypoda, and cephalopoda are the best represented classes". Shortly thereafter, Imlay (1936) applied the name Indidura Formation to rock sequences found in the rest of the Sierra Madre Oriental. Jones (1938) later reported that the fauna is of transitional character, and of Cenomanian-Turonian age.

In the Sierra de Parras region Imlay (1936) described the Indidura Formation as being in gradational contact with the infrajacent Cuesta del Cura Formation. The lower limit of the Indidura Formation in that region is marked by the appearance of gray shale beds immediately after the last chert stringer of the Cuesta del Cura Formation. Imlay (1936) estimated that the Indidura Formation in the Sierra de Parras had a maximum total thickness of about 1,900 $\mathrm{ft}(578 \mathrm{~m})$. Unlike the stratotype at Las Delicias, however, in this area the unit consists of intermittent black and gray shale beds up to $75 \mathrm{~cm}$ thick, and black to yellowish limestone beds up to $35 \mathrm{~cm}$ thick. The lowermost part of the Indidura Formation consists of an estimated 243 to 274 meters of powdery, and in places laminated, gray calcareous shales, with either lenses or thin intercalations of dark gray limestone beds. The middle part consists of an estimated 121 to 152 meters of finely laminated "salt and pepper" shales that alternate, particularly in the lower 20 meters, with sandy shales that contain lenses of brown selenite up to $80 \mathrm{~cm}$ thick. The uppermost part 
consists of 152 meters of platy, calcareous, gray shales and brown to light-gray shaly limestones with some intercalations of sandy shales including abundant selenite crystals. The uppermost segment of the Indidura Formation found in the Sierra de Parras area is in sharp contact with the overlying Parras Formation and is marked by the last appearance of a limestone bed. Imlay $(1936,1937)$ assigned a Cenomanian-Turonian age to the Formation exposed on the western part of the Sierras de Parras and suggested that it might range into the Lower Coniacian (Imlay op cit.). The suprajacent Parras Shale (Imlay 1936, Figure 3-1) is composed of black calcareous shale with interbedded dark gray siltstones; the scarcity of diagnostic fossils in this unit did not allow a direct determination of its age. 


\subsection{References}

Bishop, B.A., 1970, Stratigraphy of Sierra de Picachos and vicinity, Nuevo Leon, Mexico: The American Association of Petroleum Geologists Bulletin, v. 54, p. 1245-1270.

Burrows, R.H., 1910, Geology of northern Mexico: Boletin de la Sociedad Geologica Mexicana, p. 85-103.

Forgotson, J.M., Jr., 1957, Stratigraphy of Comanchean Cretaceous Trinity group [Gulf Coastal Plain]: Bulletin of the American Association of Petroleum Geologists, v. 41, p. 2328-2363.

Hill, R.T., 1887, The topography and geology of the Cross Timbers and surrounding regions in the northern Texas: American Journal of Science, v. 33, p. 291-303.

Humphrey, W.E., 1949, Geology of the Sierra de los Muertos area, Mexico (with descriptions of Aptian cephalopods from the La Pena Formation): Geological Society of America Bulletin, v. 60, p. 89-176.

Humphrey, W. E., Diaz, T., 2003, Jurassic and Cretaceous stratigraphy and tectonics of northeastern Mexico, Report of Investigation No. 267, Bureau of Economic Geology, The University of Texas at Austin, 152 p,+1 data CD.

Imlay, R.W., 1936, Evolution of the Coahuila Peninsula, Mexico; Part 4, Geology of the western part of the Sierra de Parras: Geological Society of America Bulletin, v. 47, p. 1091-1152.

Imlay, R.W., 1937, Geology of the middle part of the Sierra de Parras, Coahuila, Mexico: Geological Society of America Bulletin, v. 48, p. 587-630.

Imlay, R.W., 1940, Possible interoceanic connections across Mexico during the Jurassic and Cretaceous Periods: Proceedings on the Pacific Sciences Congress, v. 1, p. 423-427.

Jones, T.S., 1938, Geology of Sierra de la Pena and paleontology of the Indidura Formation, Coahuila, Mexico: Geological Society of America Bulletin, v. 49, p. 69-149.

Kelly, W.A., 1936, Evolution of the Coahuila Peninsula, Mexico; Part 2, Geology of the mountains bordering the valleys of Acatita and Las Delicias: Geological Society of America Bulletin, v. 47, p. 1009-1038.

Moran-Zenteno, D., 1994, Geology of the Mexican Republic, Tulsa, American Association of Petroleum Geologists, $160 \mathrm{p}$. 
Ross, M.A., Charleston, S., Smith, C.I., and Brown, J.B., 1981, Stratigraphy of the Tamaulipas Limestone, Lower Cretaceous, Mexico, in Charleston, S., Smith, C.I., and Brown, J.B., eds., Lower Cretaceous stratigraphy and structure, northern Mexico; field trip guidebook: Midland, TX, West Texas Geological Society, p. 43-57. 


\section{CHAPTER IV}

\section{METHODOLOGY}

\subsection{Field Methods and Data Collection Techniques}

A review of the literature on the geology of the area was carried out in order to determine both the principal structural characteristics and the position of the stratigraphic units found in the study area. The review was done in combination with field-base observations, together with aerial photographs, and Landsat 7 imagery.

\subsection{Measurement and Sampling of the Stratigraphic Succession}

The Sierra de Parras section investigated is located 3.23 kilometers west of the city of , Coahuila state; inside a canyon of an ephemeral stream that runs west of the Hacienda Perote. The geographical coordinates of the initial point of the section are $25^{\circ} 26^{\prime} 17.9^{\prime \prime}$ $\mathrm{N} ; 102^{\circ} 12^{\prime} 54.7^{\prime \prime} \mathrm{W}$, at an altitude of about 1580 meters. In order to gather precise field measurements of bed thickness the sedimentary sequence was described and measured at a centimeter to meter-scale intervals with the help of a Jacob's staff and measuring tape, in order to gather precise field measurements of bed thickness. Field descriptions of collected samples followed the guidelines proposed by Folk $(1959 ; 1962,1980)$. Position of each sample was recorded and numbered for further reference. The field descriptions included precise measurement of the different layers, which was an important aspect of the field data collection as it was critical to define variations in thicknesses, which was an 
essential part on showing frequencies or cyclicity patterns of repeated packets that may have a causal relationship with cycles that influenced sedimentary conditions.

Indicators of environmental conditions such as type of microfossils and macrofossils present, texture, primary structures: biogenic (bioturbation); lamination, marker horizons, subaqueous flows (cross-bedding, ripples, graded bed), were collected when present. These features, together with the unweathered color of the rock observed from fresh chips, were documented to asses the approximate prevalent conditions in the basin related to oxygenation levels and water column kinematics.

Secondary structures (compaction, concretions) were precisely recorded on the lithostratigraphic columns and photographed. These data gave indications of diagenetic patterns that were correlated with original conditions of sedimentation. Post depositional kinematic indicators such as joints, microfractures, and displaced layers were collected, as well, as they help in the understanding of the overall structural position of the sequence relative to the tectonic of the area, as well as providing their relative timing and development.

\subsection{Petrographic and Scanning Electron Microscope Analyses}

Laboratory descriptions of collected samples were classified following the guidelines proposed by Folk $(1959 ; 1962 ; 1980)$ for standard microscope, and Folk (1993) for electron microscope analysis. These descriptions provided a general idea of the bulk mineralogy, and preliminary elemental composition (JEOL 5900-LV Scanning Electron 
Microscope). These analytical data allowed further constraining of microfacies and mineralogical distributions throughout the stratigraphic section. SEM imaging provided observations of the intrinsic high-resolution sedimentological characteristics that helped to illustrate and confirm uncertainties of the sedimentary microstructures observed in standard petrographic microscopes.

\subsection{Micropaleontological Preparations}

Nannofossil slide preparation included several steps as follows: a clean sample of a milligram or less was obtained by carefully scraping the surface of the rock with a metal spatula on clean surfaces in order to avoid cross contamination. Scrapped material was then placed on a clean $(3 \times 1$ inch) glass slide with two to three drops of distilled water. The scrapped material was then gently smeared over the glass slide in order to avoid breaking the fragile microfossils, and then placed over a hot plate at medium heat or $70^{\circ} \mathrm{C}$ (for better adhesion of the Canada Balsam). The slide was heated for about 2 minutes until water evaporates, then a cover slip with Canada Balsam was gently placed on top to avoid any air bubbles. The slide was then left on the hot plate for 10 minutes to cure. The study of nannofossils was conducted in order to improve the biostratigraphic resolution obtained from the other paleontological methods. Nannofossil taxa were identified by Dr. Mihaela Melinte at the Geomar Institute of Sciences in Bucharest, Romania.

Samples prepared for coarse residues that include microfossils greater than 38 micrometer were treated with commercial solvents (e.g. varsol, kerosene), detergents 
(e.g. Alconox) and hydrogen peroxide $\left(\mathrm{H}_{2} \mathrm{O}_{2}\right)$ or a combination of these methods whenever appropriate for better disaggregating results. After the initial break-up, samples were thoroughly washed with tap water through a series of sieves $(150-38 \mu \mathrm{m})$ until the coarse residue was free of clay, and both silt particles and microfossils were loose. Dry coarse fraction was studied under a binocular microscope and SEM. The study of the foraminifera and radiolaria was carried out in an effort to characterize index taxa that may be helpful for biostratigraphy, as well as for overall compositional make up of the planktonic assemblages. Special attention was given to taxonomic successions and turnovers, and their possible correlation with organic carbon accumulation as observed in worldwide sections of the same age (Bralower et al., 1994 and references therein).

\subsection{Geochemical Analyses}

\subsubsection{Inorganic geochemistry}

\subsubsection{Carbon and Carbonate Content}

Analyses were conducted on all non-weathered samples using a Leco CR-412 analyzer. This method uses in general $0.025-0.5 \mathrm{~g}$ by weight of powdered sample per run. For the total carbon content (TC), samples were powdered with a micro-mill, desiccated below $50^{\circ} \mathrm{C}$ for 2 hours and stored until analysis is carried out. Each sample was weighed in duplicate in a combustion boat and run in the LECO CR-412 analyzer; which provides a print-out of the results with the percentage of TC in the sample. To obtain total organic carbon (TOC) the procedure is similar to the TC, except that after initial desiccation samples were placed in a furnace at $500^{\circ} \mathrm{C}$ to remove the organic carbon. The differences in weight percent obtained for the duplicate sample allowed the calculation of the 
percentage of organic carbon present in the sample by subtracting from the TC value. To obtain the $\mathrm{CaCO}_{3}$ value, the results for were subtracted from the previously obtained $\mathrm{CaCO}_{3}=\mathrm{TC}-(\mathrm{TOC} * 8.33)$, the 8.33 factor corresponds to the mass ratio of the $\mathrm{C}$ atom per molecule of $\mathrm{CaCO}_{3}$.

\subsubsection{Major Elements and Trace Metals}

Sample preparation to determine trace metals used the EPA method 3050b (USEPA, 1996), which involves partial digestion of the rock in strong acids that allows extraction of the trace metals related to its organic matter. Acids used for the analyses were trace metal grade, the water was distilled and deionized, and $\mathrm{H}_{2} \mathrm{O}_{2}$ was optima grade. The procedure for major and trace element analyses was as follows: 1 gram of sample was digested in $10 \mathrm{ml}$ of $1: 1 \mathrm{HNO}_{3}$ at $95^{\circ} \mathrm{C}$ for 10 minutes, with addition of $5 \mathrm{ml}$ of $1: 1$ $\mathrm{HNO}_{3}$ until no more brown fume was released. The treated sample was left on the hot plate at $95^{\circ} \mathrm{C}$ until all liquid acid evaporates; then $2 \mathrm{ml}$ of water and $3 \mathrm{ml}$ of $\mathrm{H}_{2} \mathrm{O}_{2}$ were added to the dry residue, with continuous addition of $1 \mathrm{ml}$ of $\mathrm{H}_{2} \mathrm{O}_{2}$ until bubbling subsided. The residue was covered and heated for 2 hours at the same temperature, and then $10 \mathrm{ml}$ of 1:1 HCL were added and allowed to reflux for 15 minutes. After this process the sample was filtered and diluted to volume $(100 \mathrm{cc})$ with distilled/deionized water. The resulting solutions were analyzed with a Jobin Yvon JY 70 Type III Inductively Coupled Plasma Atomic Emission Spectrophotometer (ICP-AES) for $\mathrm{Na}, \mathrm{Ca}$, $\mathrm{Fe}, \mathrm{Mn}, \mathrm{Mg}, \mathrm{Mo}, \mathrm{V}, \mathrm{Cr}, \mathrm{Cu}, \mathrm{Ni}$, and $\mathrm{Zn}$ ) with an estimated precision of $\pm 5 \%$ for major elements, and $\pm 7 \%$ for trace metals. 


\subsubsection{Stable Isotopes on C Organic}

Stable isotope analyses of Carbon were carried out on the organic fraction with a Finnigan Delta C EA-IRMS (with TC/EA). For the stable isotope analyses, the technique used $0.1-90 \mathrm{mg}$ of powdered rock per run. Each sample was treated with $\mathrm{HCl}$ to remove carbonate fraction and sulphur present in the rock. Oxidation was induced at temperatures between 850 and $1000^{\circ} \mathrm{C}$ in a stream of oxygen, or in the presence of a $\mathrm{CuO}$ catalyst. Ratios obtained were compared repeatedly with a laboratory reference gas under identical conditions and values are presented as a deviation of the PDB "Peedee Belemnite" standard.

\subsubsection{Organic Geochemistry}

\subsubsection{Biomarkers}

Analyses were conducted on rock samples with at least $100 \mathrm{mg}$ of organic carbon. The rock powder was weighed and extracted in dichloromethane for 24 hours in a Soxhlet apparatus, where a known quantity of internal standard squalene was added. The extract obtained was concentrated through rotary-evaporation under vacuum at $30^{\circ} \mathrm{C}$; the extract was then saponified with $25 \mathrm{ml}$ of $1 \mathrm{~N} \mathrm{KOH}$ to separate the acids from the neutral lipid fractions (Jaffe et al., 2001). After elution with hexane, the hydrocarbon fraction was analyzed with a GC/MS on a HP 6890 GC interfaced to an HP 5973 quadrupole scanning mass spectrometer. A 5\% phenyl methylsilicon bonded phase (J \& W DB-5MS) fused silica capillary column $(30 \mathrm{~m} \times 0.25 \mathrm{~mm}$ i.d. $\times 0.25 \mathrm{um}$ film thickness $)$ was used for the separation. The GC oven was programmed to hold initial temperature of $40^{\circ} \mathrm{C}$ for $1 \mathrm{~min}$, and then ramped at a rate of $6^{\circ} \mathrm{C} / \mathrm{min}$ to a final temperature of $300^{\circ} \mathrm{C}$ held for $20 \mathrm{~min}$. 
Chromatograms of the results were analyzed and identified by comparison with the Wiley275 mass spectra library.

\subsection{Spectral Analyses}

Image methodology used in this dissertation involves image analysis together with time series analysis techniques (e.g. wavelet analysis and spectral analysis) in order to determine the continuity and periodicities that are tied to two-age frequency domains (e.g. decadal, Milankovitch). The program used to analyze the datasets was AutoSignal v.1.7 by SYSTAT, which allowed resolving both Fourier analysis and Continuous wavelet transforms CWT. I followed Patterson et al., (2004) by using a scaling ratio of 10 , which has shown good resolution in the periodicity domain, as well as "zero padding" at the beginning and end of the data series to reduce edge effects. Data were standardized to a mean $=0$ and detrended. The final representation diagram in the time-frequency domain is known as a scalogram. Data is represented in the time series as gray scale intensities, thickness and TOC \%.

Here a continuous wavelet analysis CWT, and spectral analysis were carried out to the datasets to quantify the presence of cyclicity, and bandwidth dependent relations between the different time-series. Continuous wavelet transforms CWT as discussed by (Patterson et al., 2004) are mathematical correlation functions that break the data into smaller series frequency components as functions of time, and then each of the frequencies are individually analyzed at a resolution appropriate to its time-scale (Graps, 1995). This 
approach was originally described and developed by Fourier (1822), where he described that any function can be approximated by a superposition of sines and cosines.

However CWT was chosen over the Fourier analysis because CWT transform has the advantage of performing analyses to both the time and the frequency domains. The CWT uses as well a variable size window, an important characteristic that allows CWT to recognize high-frequency changes or cycles present in sedimentary sequences (Patterson et al., 2004) and enhances its geological application. The continuous wavelet transforms (CWT) process further permits to observe data at different frequency scales, making it particularly useful in geosciences (Graps, 1995).

\subsubsection{Data for Spectral Analysis of $\mathrm{TOC} / \mathrm{CaCO}_{3}$}

Data used for the spectral analysis combined stratigraphic position and bed thickness with TOC variation obtained from the total organic carbon analyses performed on the LECO CR-412 as discussed previously in section 4.5.1.1.

\subsubsection{Data for Spectral Analyses of Thin Sections}

In order to carry out spectral analyses of micro-scale variations in the sediment, images were acquired in TIFF-format and then edited with COREL PHOTO PAINT image

processing software. Thin sections were scanned and digitized at a resolution of 500 pixel/cm, resulting in about 3000 linear pixel/thin section. Photomicrographs were used at a resolution of 1000 pixels $/ \mathrm{cm}$ on the whole thin section in order to measure individual laminae, and to identify mineralogical and compositional variations. ERDAS Image 8.7 
was then used to generate gray-scale values measured in strips perpendicular to the lamination. These values were recorded on a spreadsheet, and by interpolating gray scale values from adjacent pixels they were further corrected for extreme gray-values caused by small calcite veins, foraminifers and other large particles. 


\subsection{References}

Bralower, T.J., Arthur, M.A., Leckie, R.M., Sliter, W.V., Allard, D.J., and Schlanger, S.O., 1994, Timing and paleoceanography of oceanic dysoxia/anoxia in the late Barremian to early Aptian (Early Cretaceous): Palaios, v. 9, p. 335-369.

Folk, R.L., 1959, Practical petrographic classification of limestones: Bulletin of the American Association of Petroleum Geologists, v. 43, p. 1-38.

Folk, R.L., 1962, Spectral subdivision of limestone types: Memoir 1 - American Association of Petroleum Geologists, p. 62-84.

Folk, R.L., 1980, Petrology of sedimentary rocks: Austin, TX, Hemphill Publ. Co., p. 184.

Folk, R.L., 1993, SEM imaging of bacteria and nannobacteria in carbonate sediments and rocks: Journal of Sedimentary Petrology, v. 63, p. 990-999.

Fourier, J.B.J., 1822, Theorie analytique de la chaleur: Paris, F. Didot, p. 639.

Graps, A., 1995, An Introduction to Wavelets: IEEE Computational Science and Engineering, v. 2, p. 50-61.

Jaffe, R., Mead, R., Hernandez, M.E., Peralba, M.C., and DiGuida, O.A., 2001, Origin and transport of sedimentary organic matter in two subtropical estuaries: a comparative, biomarker-based study: Organic Geochemistry, v. 32, p. 507-526.

Patterson, D.T., Prokoph, A., Wright, C., Chang, A.S., Thomson, R.E., and Ware, D.M., 2004, Holocene Solar Variability and Pelagic Fish Productivity in the NE Pacfic: Palaeontologia Electronica, v. 7, p. 17-http://palaeoelectronica.org/2004 1/fish2/issue 1 04.htm.

U.S. Environmental Protection Agency, 1996, Test methods for evaluating solid waste, SW 846, 3d ed.: Washington, Office of Solid Waste and Emergency Response, USEPA, $3500 \mathrm{p}$. 


\section{CHAPTER V}

\section{LITHOSTRATIGRAPHY}

The following field work was carried out in January of 2003, at a locality west of the Hacienda de Perote Parras de la Fuente (Coahuila de Zaragoza), NE Mexico. The study focused essentially on rocks of the Indidura Formation that crop out along a gully adjacent to the hacienda (Figure 5-1) where an excellent transect of the Formation was easily accessible. Detailed field observations and sampling along that transect provided essential data for all the subsequent petrographical, geochemical and cyclicity analyses that I used for sedimentological and paleoecological interpretations. The results also further our understanding on existing processes during the deposition of the sedimentary sequence broadly placed under the name of Indidura Formation in northeastern Mexico.

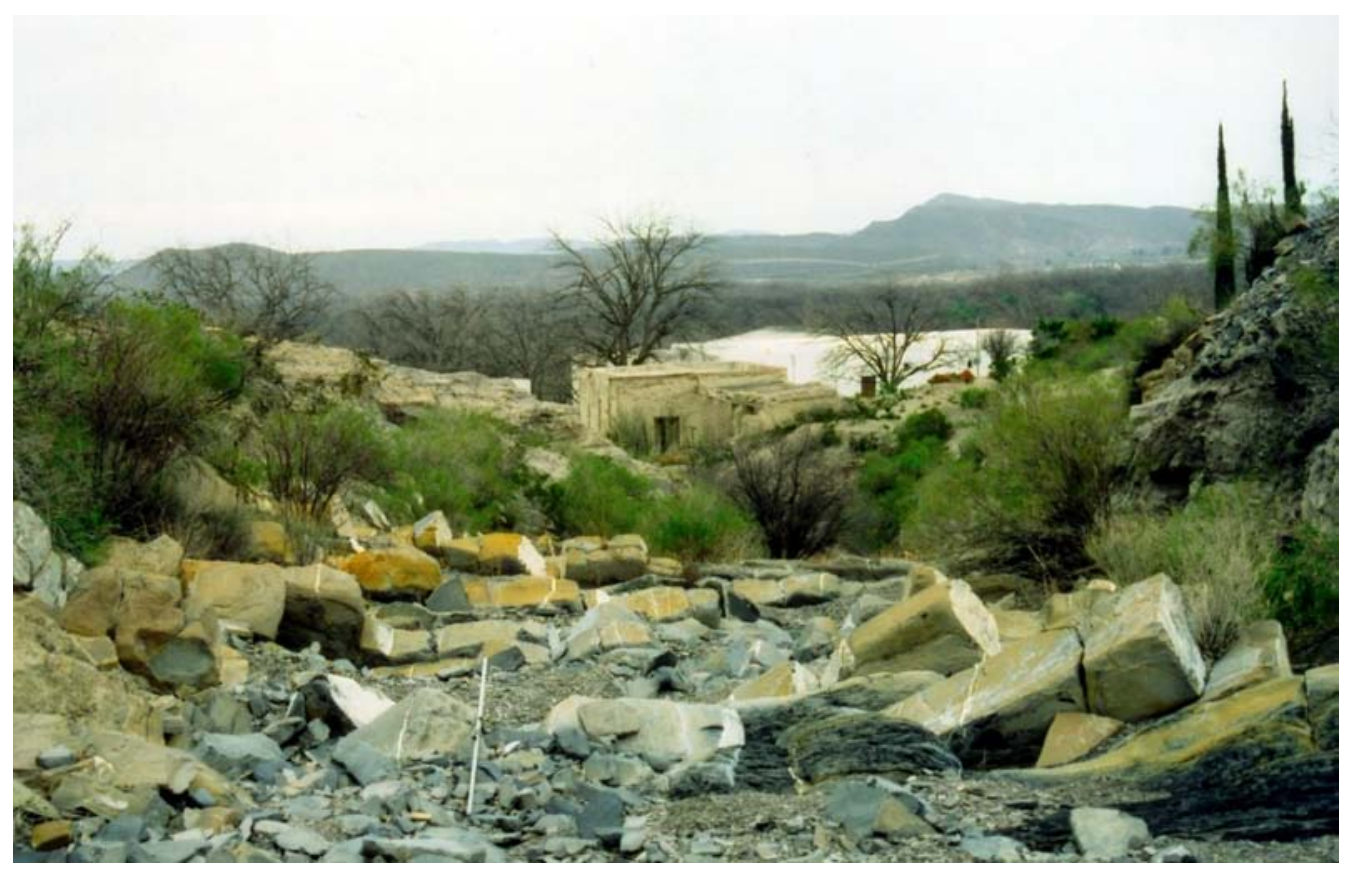

Figure 5- 1. Panoramic view of the section west of Parras de la Fuente, the Hacienda de Perote is in the foreground. 


\subsection{Field-scale description of the unit at the Hacienda de Perote.}

Precise localization of the stratigraphic section at the Hacienda de Perote is given by the GPS coordinates of $25^{\circ} 26^{\prime} 17.9^{\prime \prime} \mathrm{N}$; $102^{\circ} 12^{\prime} 54.7^{\prime \prime} \mathrm{W}$, which is about 3.23 kilometers west of town hall of Parras de la Fuente. The study site is accessed through the Hacienda's property into the deep gully situated just north of the main house. The stream valley runs north-south, and is characterized by a slope close to $15^{\circ}$, and the stratigraphic sequence was measured along 207 meters of a section on the northern limb of an anticline just above the plains. The excellent exposure along the gully floor and banks allowed for a good observation and description of the sedimentary sequence. Although there are some intervals covered with slope wash, no major offsets (e.g. thrust faults) were observed to

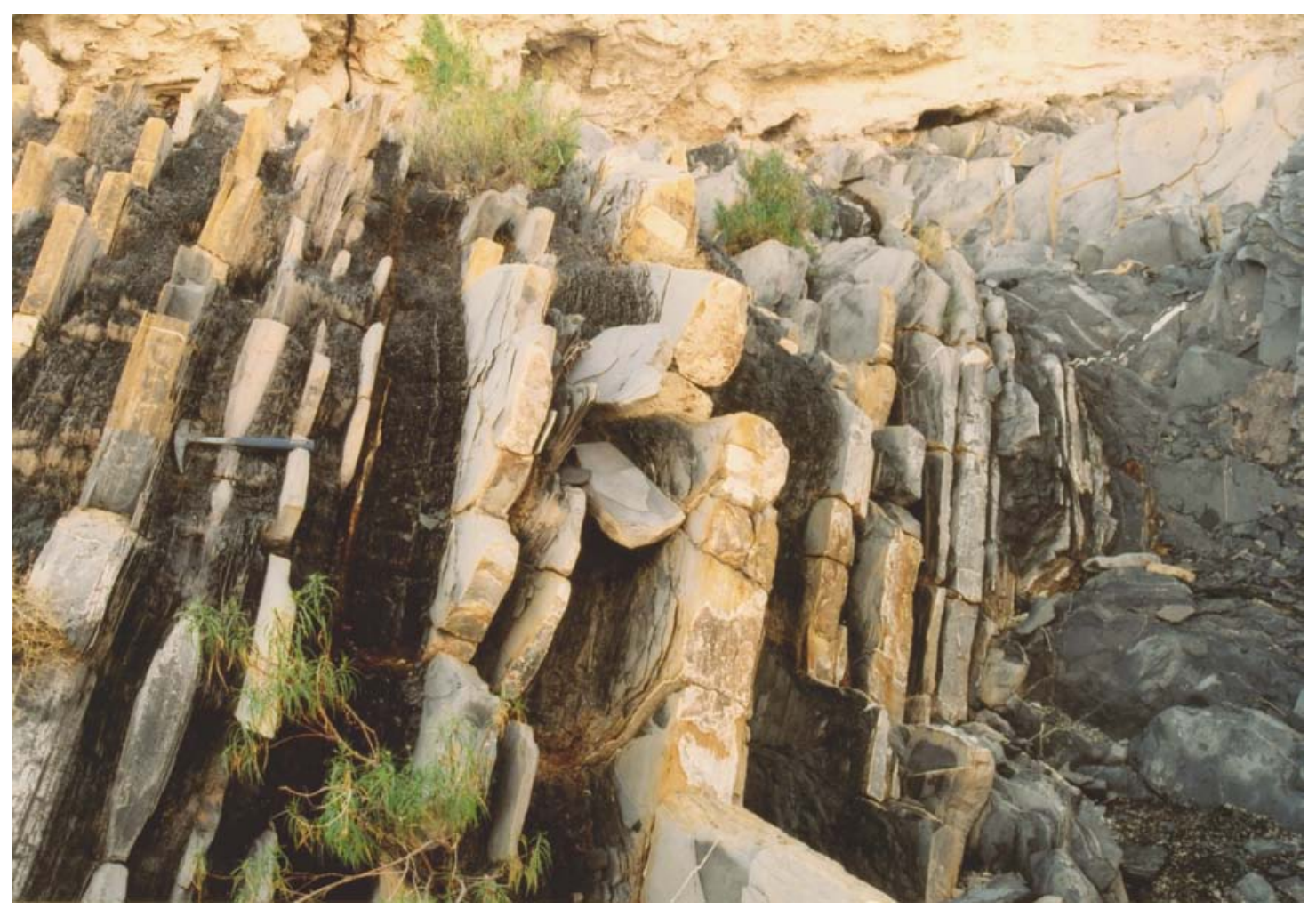

Figure 5- 2. Typical intercalations of the middle part of the Indidura Formation, hammer is $33 \mathrm{~cm}$ long. 
disrupt the normal succession (Figure 5-6). The studied section would correspond to the middle part of the Indidura Formation found in the Sierra de Parras sensu Imlay (1936).

Overall, the sedimentary sequence found at the Hacienda de Perote consists of interbedded packages of light olive-gray (5Y6/1) and brownish-black to olive-black (5YR2/1 - 5Y2/1) marlstone arranged in thin $(\mathrm{ca} .5 \mathrm{~cm})$ to very thick $(\mathrm{ca} .200 \mathrm{~cm})$ beds; and brownish-black to olive-black (5YR2/1 - 5Y2/1) marly biocalcilutites arranged in thin $(\mathrm{ca} .8 \mathrm{~cm}$ ) to very thick $(\mathrm{ca} .100 \mathrm{~cm}$ ) beds as shown in Figure 5- 2. A salient characteristic of the measured section is that the different layers have a greater thickness in the lower $100 \mathrm{~m}$ of the stratigraphic succession, where the marly biocalcilutites beds have an average thickness of $50 \mathrm{~cm}$ and the marlstones beds of $1.5 \mathrm{~m}$. The average

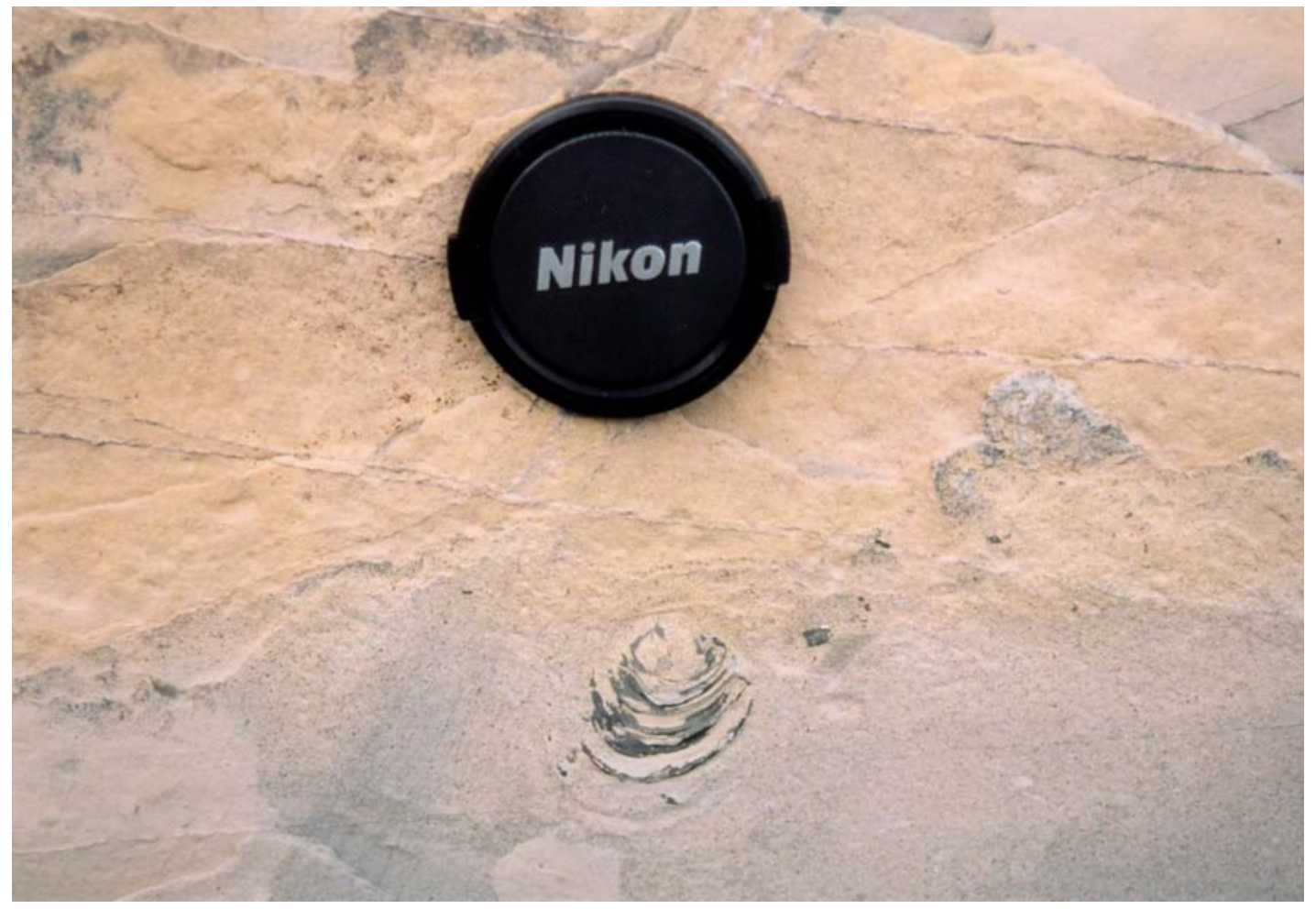

Figure 5-3. Some scarce and small Inoceramus labiatus? are found occasionally in the sequence. 
thickness decreases in the superjacent $70 \mathrm{~m}$, where the marly biocalcilutite and marlstone beds are about $15 \mathrm{~cm}$ and $50 \mathrm{~cm}$, respectively. Also, the beds show a highly repetitive and regular arrangement.

The uppermost 50 meters of the section shows recurrent thickening of the beds similar to the first part of the measured sequence, with an average thickness of $50 \mathrm{~cm}$ for the marly biocalcilutite and of $1.5 \mathrm{~m}$ for the marlstone beds. Thus, the facies succession shows an upward bed thinning that extends to about $140 \mathrm{~m}$ where the bed thickness decreases to an average of $10 \mathrm{~cm}$ for both lithologies, and then starts to slowly increase again until the end of the measured section.

The sequence at the Hacienda de Perote is monotonous as it contains no apparent macrofossils, except for occasuional and very rare Inoceramus labiatus? (Figure 5- 3), and ammonites. Primary sedimentary structures related to hydrodynamic conditions are well preserved and readily observed at the outcrop scale because the sediment is generally not bioturbated, although sporadically some beds do show ichnofossils (Figure 5- 4). e.g. Thallasinoides.

At the outcrop scale all beds exhibit primary internal sedimentary structures that consist of even-parallel to wavy-parallel laminae; curved-parallel laminae are observed at some levels, but they never become the predominant type of internal lamination observed in the section. Marly biocalcilutites beds, specially the ones that occur above the first $90 \mathrm{~m}$ of the measured section show better-defined laminae than the marlstones beds, although all 
units in the measured sequence are internally laminated. Marlstone compromises more than $60 \%$ of the measured interval with the marly biocalcilutites completing the rest. Close observation of contact surfaces between beds shows that most of the contacts are rather sharp, although a diagenetic evolution of the carbonate inside the different lithologies may have enhanced the bed boundaries as observed in other carbonate-rich sequences (Einsele and Ricken, 1991).

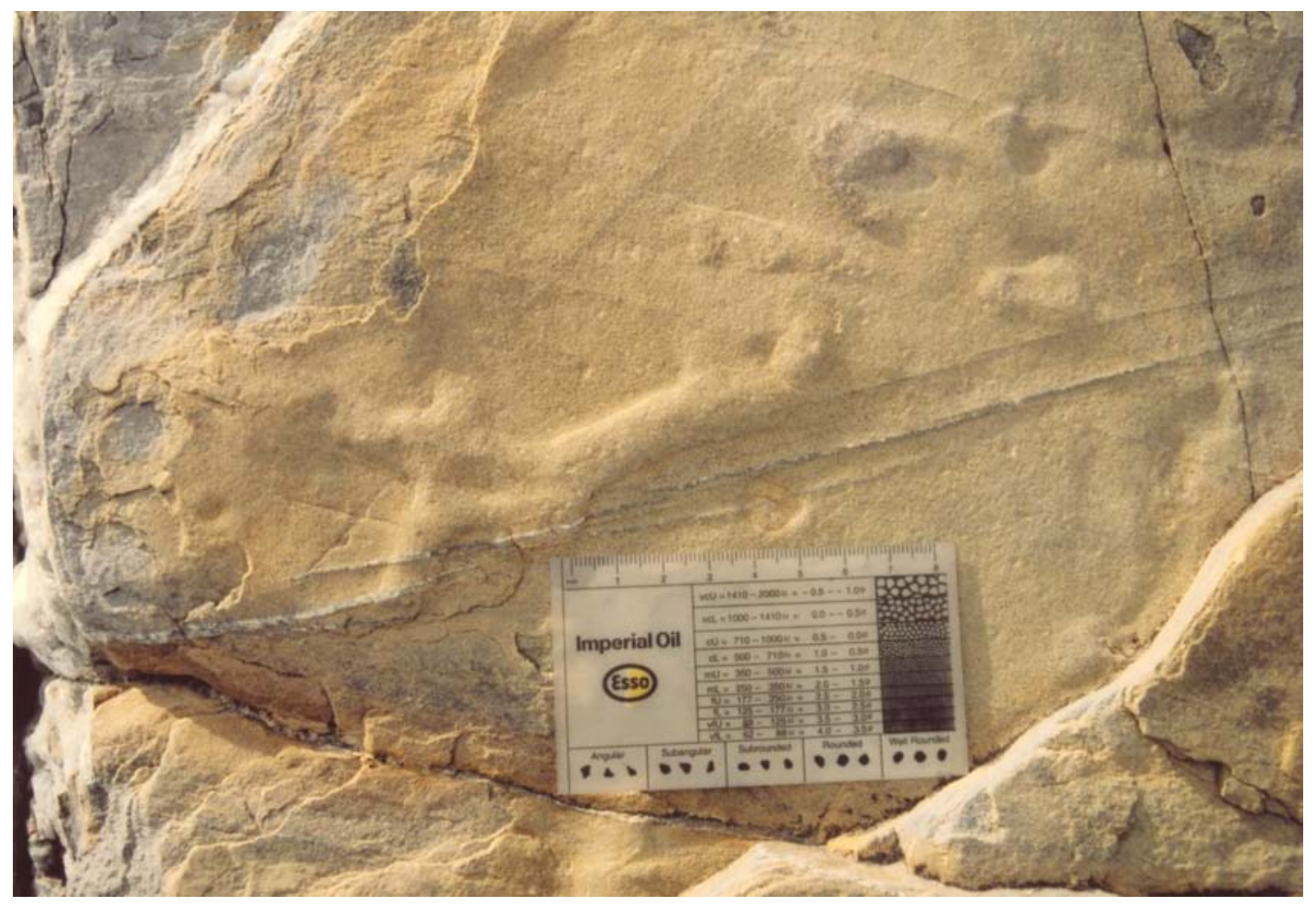

Figure 5- 4. Ichnofossils, possibly of the ichnogenus Thallasinoides are found on some of the marly biocalcilutites beds.

All together, the most striking characteristic of these beds is the presence of persistent dark and light parallel laminae 1 to $2 \mathrm{~mm}$ thick. When observed with the hand-lens laminae can be easily discerned, and with a thorough observation reveals that laminae are continuous over most of the length of the hand samples (ca. $10 \mathrm{~cm}$ ). The typical 
arrangement of laminae shows continuous laminasets through the beds, and they have a quasi-periodic arrangement (Figure 5- 5).

\subsection{Microscopic observations}

Detailed examination under plane and cross-polarized light microscope allowed furthering the identification of the microfossils, microstructures of the internal laminae, and qualitative composition of the minerals observed in thin sections.

The polarizing microscope reveals even parallel to wavy-parallel micro-laminae composed primarily of calcareous objects in the shape of microspheroids that are either individual grains, or aggregates of calcite rhombohedra of 1-3 $\mu \mathrm{m}$. The microspheroids range in size between 5 and $100 \mu \mathrm{m}$, with a median size of $20 \mu \mathrm{m}$, and are discernible as multiple-crystal calcite-filled structures. The microscopic structures of the laminae further indicate that they are formed of quasi-periodic occurrence of dark and light subunits forming couplets reminiscent of deposits described as "varves", although there is no apparent petrogenetic relationship with that type of sediment. Micro-laminae are more distinct in the highly laminated marly calcilutite beds than in the marlstone beds, because laminae are created by the varying abundances of microspheroids as seen in thin sections (Figure 7- 4, Figure 8-4). Light laminae are composed of greater than $95 \%$ of "microspheroids" (Figure 8- 4). The groundmass, or finer components, make up less than $5 \%$ in the light laminae, whereas it is dominant in the dark ones where microspheroids become less abundant $(<10 \%)$. Although microspheroids are the dominant carbonate components of the sediments, the darker laminae also include scattered planktonic 


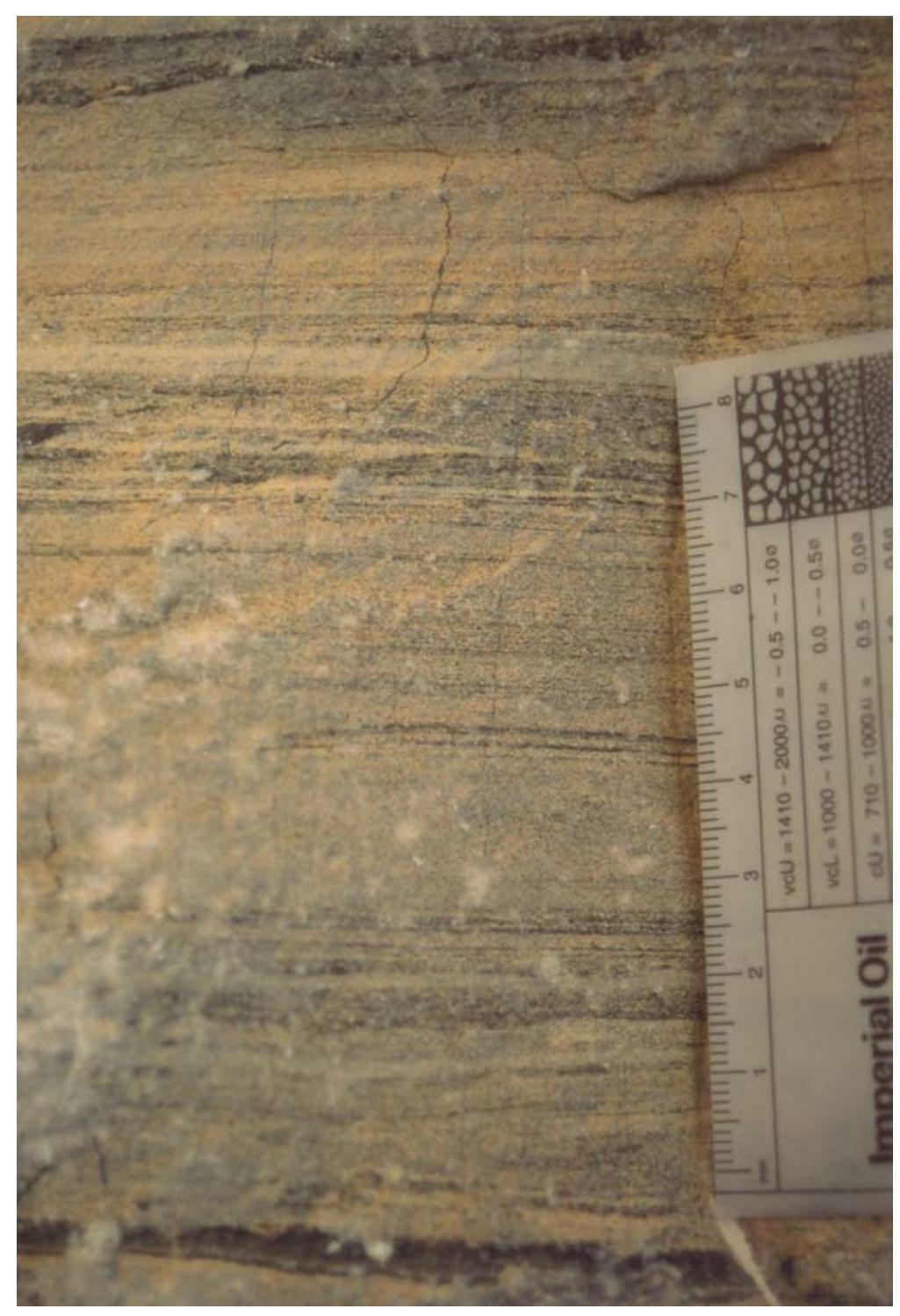

Figure 5- 5. Conspicuous laminae are the primary sedimentary features readily observed in the unit, these features are typically arranged in couplets that range from sub-millimeter to millimeter scale.

foraminifera (mainly heterohelicids and double keeled forms), and scarce radiolarians (spumelarids). Undifferentiated clay-size particles together with organic matter make up the rest of the dark laminae. On the whole, dispersive framboidal pyrite occurs as aggregates up to $5 \%$ of the bulk sediment, while diagenetic pyrite cubes make up less 
than $2 \%$. Microsparite constitutes the main conspicuous cement, although cementation by clay minerals cannot be ruled out and is out of the scope of the research.

\begin{abstract}
Although at the macroscopic scale laminae exhibit an apparent lateral continuity, when observed under the microscope it becomes clear that laminae are discontinuous, since they occur as uneven discrete units with pinch and swell structures within a fine-grained calcareous matrix.
\end{abstract}




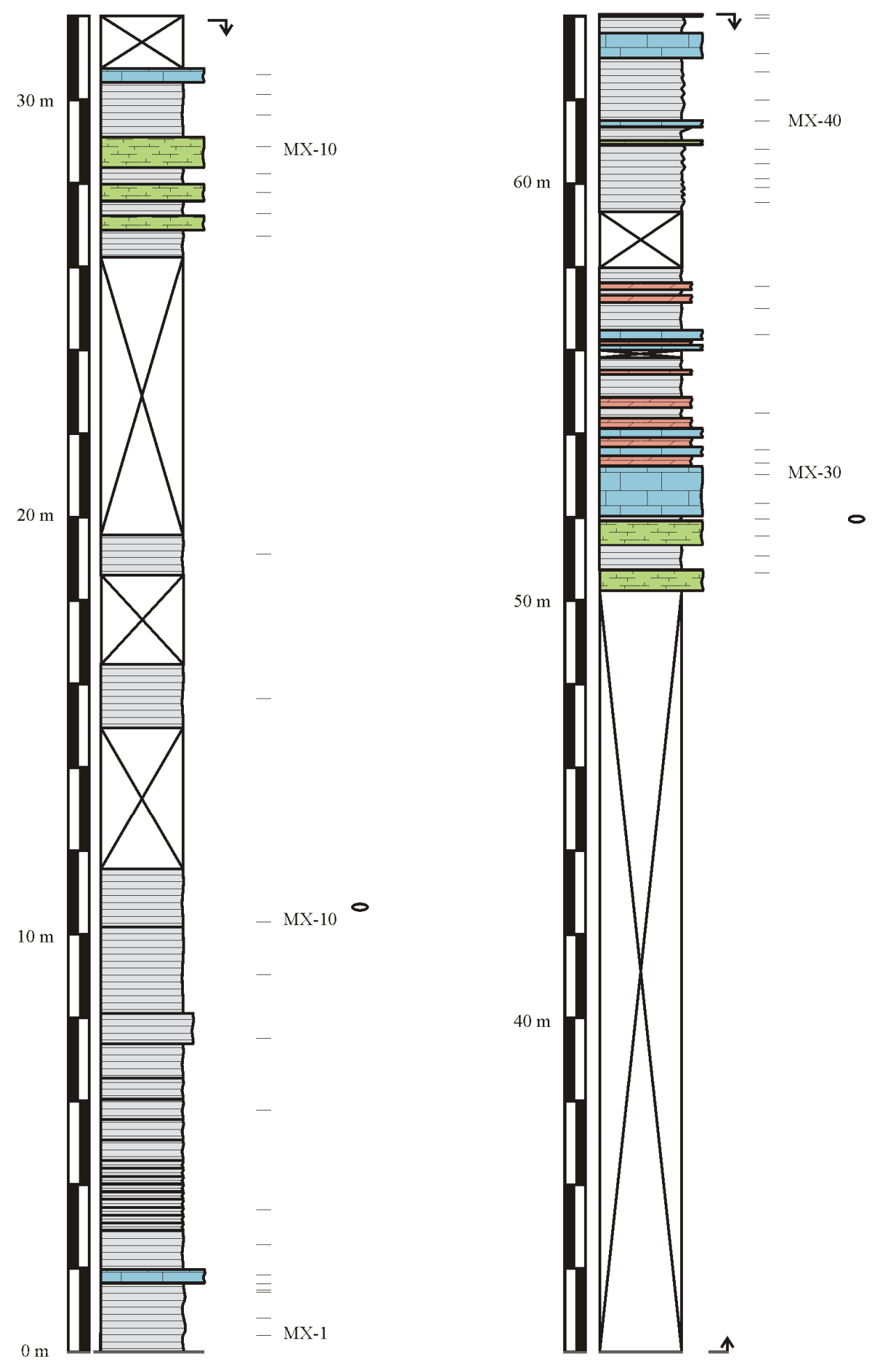

Figure 5- 6. Stratigraphic section of the Indidura Formation west of Parras de la Fuente at the Hacienda de Perote. 

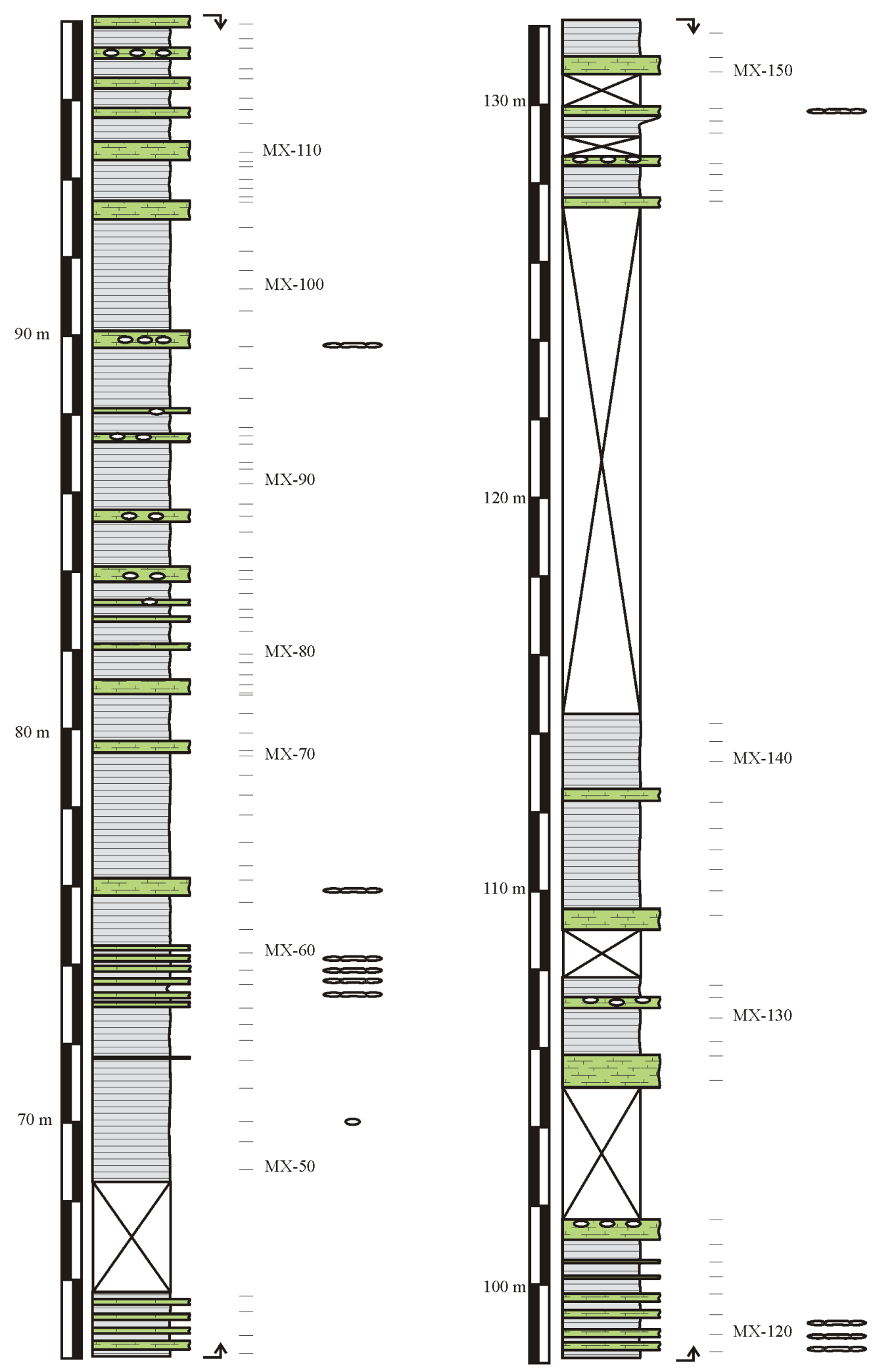

Figure 5- 6. Stratigraphic section of the Indidura Formation west of Parras de la Fuente at the Hacienda de Perote (continued). 

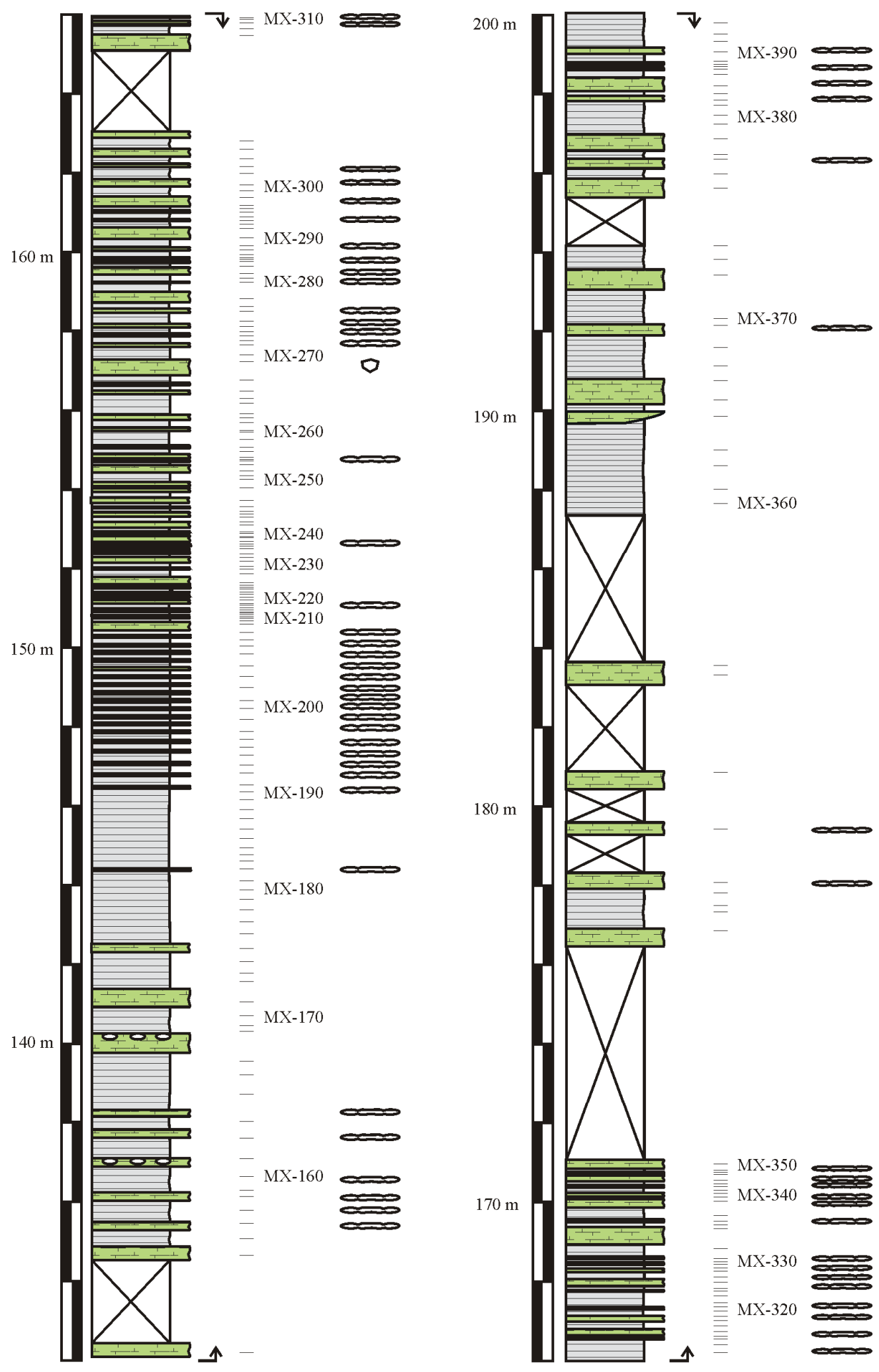

Figure 5- 6. Stratigraphic section of the Indidura Formation west of Parras de la Fuente at the Hacienda de Perote (continued). 

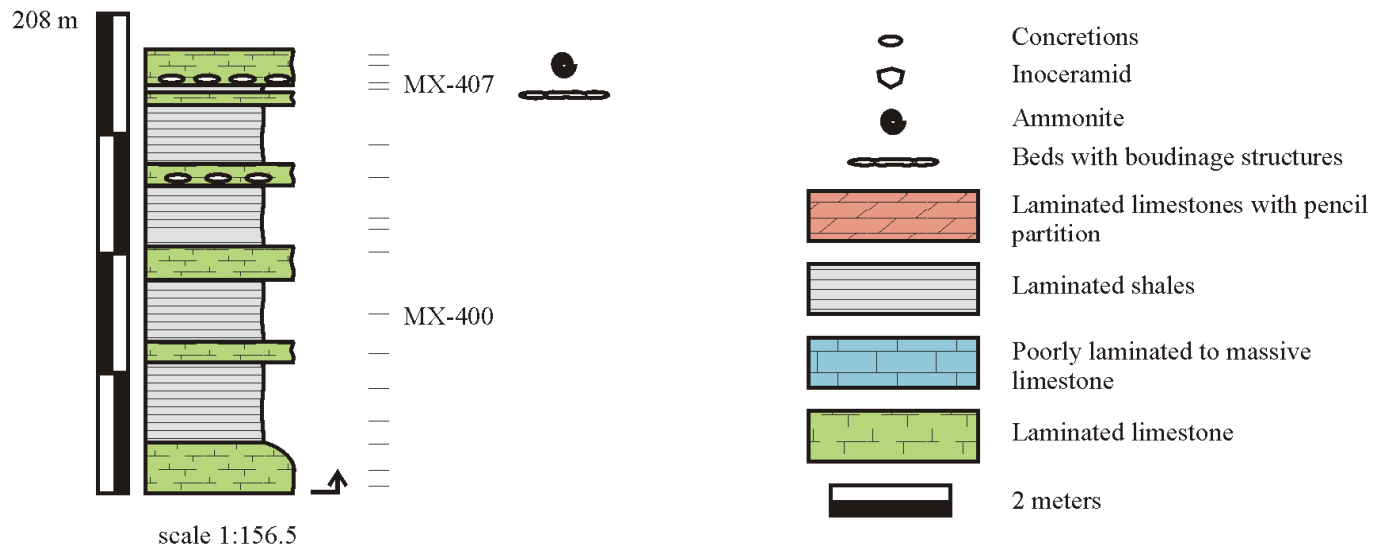

Figure 5- 6. Stratigraphic section of the Indidura Formation west of Parras de la Fuente at the Hacienda de Perote (continued). 


\subsection{References}

Einsele, G. and Ricken, W., 1991, Limestone-marl alternations; an overview, in Einsele, G., Ricken, W., and Seilacher, A., eds., Cycles and events in stratigraphy: Berlin, Springer Verlag, p. 23-47. 


\title{
CHAPTER VI
}

\section{Cyanobacterial Productivity, Variations in the Organic Carbon, and Facies of the Indidura Formation (Cenomanian-Turonian),} Northeastern Mexico

\author{
Fabian Duque-Botero $^{\mathrm{a}}$ and Florentin J-M.R. Maurrasse ${ }^{\mathrm{a}}$ \\ ${ }^{a}$ Florida International University, Department of Earth Sciences \\ Published in Journal of Iberian Geology (31), 85-98, 2005
}

\subsection{Abstract}

Rock sequences of Cenomanian-Turonian age commonly assigned to the Indidura Formation in northeastern Mexico (Coahuila State) show distinct facies indicative of significant spatial variability over the carbonate platform. Three stratigraphic sections were selected to characterize these differences.

Las Delicias section (stratotype) is composed of $10-30 \mathrm{~cm}$ thick beds of very-pale orange biocalcirudites, without internal primary structures. Allochems consist of abundant echinoderms, pelecypods, ammonites, and fewer planktonic foraminifera. Total carbonate $\left(\mathrm{CaCO}_{3}\right)$ varies between $48 \%$ and $94 \%$, and total organic carbon (TOC) between $0.7 \%$ and $1.5 \%$.

La Casita Canyon section, southeast of Las Delicias, consists of 3-30 cm thick interbeds of pale yellowish brown biocalcilutites and olive gray shales. Hand specimens show no 
apparent depositional internal structures, whereas abundant bioturbation appears in thin sections. Allochems consist of sparse fragments of planktonic foraminifera and radiolaria concentrated in burrows. Total carbonate $\left(\mathrm{CaCO}_{3}\right)$ varies between $0.8 \%$ and $59.3 \%$, whereas TOC fluctuates between $0.17 \%$ and $5.8 \%$.

In contrast, the Sierra de Parras section, south of Las Delicias and west of La Casita, includes a sequence with well defined rhythms. They consist of 8-200 cm thick beds of light olive gray and brownish black, to olive black shales; and 5-100 $\mathrm{cm}$ thick marly biocalcilutites. Both facies exhibit similar internal structures arranged in nearly evenparallel "varve-like" dual lamination ( $<3 \mathrm{~mm}$ thick). Microscopically, they include few planktonic foraminifera scattered in the dark laminae. Epifaunal remains include only sporadic pelecypods (Inoceramus). Total carbonate $\left(\mathrm{CaCO}_{3}\right)$ content varies from $43 \%$ to $78.3 \%$, while TOC is relatively high between $7.3 \%$ and $24.3 \%$, more often higher than 20\%. Microfacies in the Parras area reveal compositional differences in the laminae associated with varying abundance of microspheres or "micro-ooids" that we attribute to be of cyanobacterial origin. Laminae developed from fluctuating cycles of calcareous cyanobacteria blooms, which remained dominant throughout the sequence. $\mathrm{C}_{\text {organic-rich }}$ black shales and limestones of the Parras region further document unique paleoceanographic conditions, which were also characterized by strong dysoxic/anoxic bottom conditions and rhythmical production of cyanobacteria. These conditions contrast sharply with prevailing paleoenvironments recorded at Las Delicias and La Casita where benthic epifauna, planktonic and nektonic organisms were able to thrive. Assuming that 
these facies are coeval, microfacies and TOC analyses of these rocks further demonstrate distinct spatial differences between these areas.

\subsection{Introduction}

Evolution of Cretaceous oceans includes several episodes of Oceanic Anoxic Events (OAEs) that are particularly well recorded in Corganic-rich sediments around the Tethys from the Early Jurassic (Borrego et al., 1996) up to the Cenomanian/Turonian (C/T) boundary time (Lamolda, 1978; Lamolda and Mao, 1999). Geochemical studies of Cretaceous sediments around the Tethyan realm led to further quantitative interpretations of the paleoclimatic and paleoceanographic conditions at that time (Schlanger and Jenkyns, 1976; Jenkyns, 1980; Arthur and Premoli-Silva 1982; Arthur et al., 1990). Oceanic Anoxic Events (OAEs) are characterized by extensive preservation of organic carbon associated with widespread accumulation of "black shales" (Jenkyns, 1980; Bralower et al., 2002). The $\mathrm{C} / \mathrm{T}$ interval is not only widely associated with deposition of black shales during the Oceanic Anoxic Event designated as OAE2, also known as the "Bonarelli Event", but it is also characterized by the extinction of numerous taxa (Harries and Kauffman, 1990).

As recorded elsewhere, sediments deposited in the shallow epicontinental seas that extended over northeastern Mexico also indicate that general conditions of sedimentation favored the preservation of organic carbon from the Jurassic to the Cretaceous. As for plausible causes of such unusual preservation of Corganic-rich compounds in the lower Aptian (OAE 1b) of the La Peña Formation of northeastern Mexico, Barragan (2000) and 
Barragan and Maurrasse (2000) proposed that oxygen depletion caused an enhancement of the oxygen minimum zone due to an increase in oceanic water temperature related to tectonovolcanic effects associated with the Pacific super-plume events, which produced excess heat flux at that time. Their interpretation is compatible with Tatsumi et al., (1998) inference that elevated temperatures, as well as changes in ocean chemistry, oceanic circulation and sea level, were all factors that played a major role in oxygen depletion events during the mid-Cretaceous hypoxic conditions. Hence, the net result of the superplume events associated with the lower Aptian (OAE 1b) is distinguished by a general enhancement of the oxygen minimum level in the Tethyan realm and epicontinental seas where there was an increase in TOC, (up to $20+\%$ ), in the La Peña Formation, for instance. The patterns of occurrence/disappearance of the benthic fauna (Barragan, 2000; Barragan and Maurrasse, 2000) further corroborate the anoxic conditions coincident with OAE $1 \mathrm{~b}$.

In the present work we discuss the different facies commonly assigned to the Indidura Formation, and focus special attention to sediments in the Parras Mountains, a rock sequence from northeastern Mexico (Figure 6 - 1), which covers the C/T boundary, a time also known to include a significant Oceanic Anoxic Event. With still many unanswered questions concerning the Corg-rich Cretaceous sediments of that time, the present work presents geochemical and petrographic analyses that will shed further light on our understanding of the sedimentary cycles and Corg-rich events of the Indidura Formation (Duque-Botero and Maurrasse, 2002a,b). We also present evidence of the role played by cyanobacteria in the biological-sedimentological processes that were 
significant in the formation of Corg-rich deposits in northeastern Mexico, and perhaps similar processes may be applicable elsewhere in the geological record

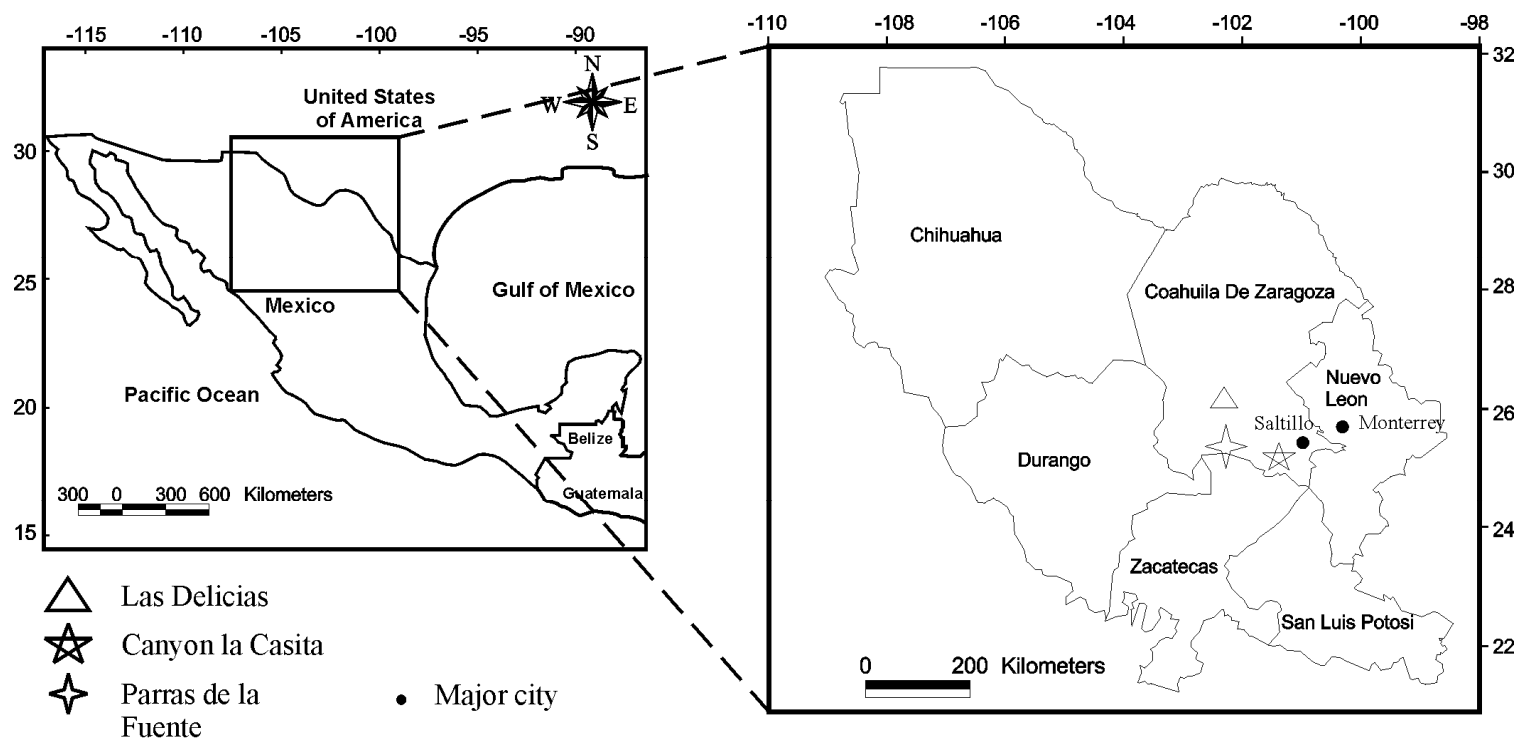

Figure 6 - 1. Map of Mexico showing the location of the study region in relation to northeastern Mexico. Close up of the region with localization of the three stratigraphic sections.

\subsection{Physical Stratigraphy of the Study Area}

It has long been recognized that Cretaceous rocks of northeastern Mexico indicate that complex and lasting shallow-platform environments were established over the area since at least the Valanginian (Imlay, 1936). The general stratigraphy (Figure 6 - 2) includes the following predominately calcareous units: The Taraises Formation composed of calcareous shales and fossiliferous limestones with intervals rich in mollusks (Imlay, 1936). The type locality may include Berriasian to lower Hauterivian strata (Humphrey and Diaz, 2003). The Capulin Formation (Humphrey and Diaz, 2003), formerly referred to as Las Vigas Formation by Imlay (1936) following the work of Burrows (1910). The formation is composed "principally of fine- to medium-grained brown to yellowish brown calcareous sandstones and siliceous, shaly somewhat sandy limestones" 
(Humphrey and Diaz, 2003). According to Humphrey and Diaz (2003) the formation does not include diagnostic fossil to allow its time stratigraphic correlation. Nonetheless, based on its stratigraphic position, they suggest that it may lie between the late
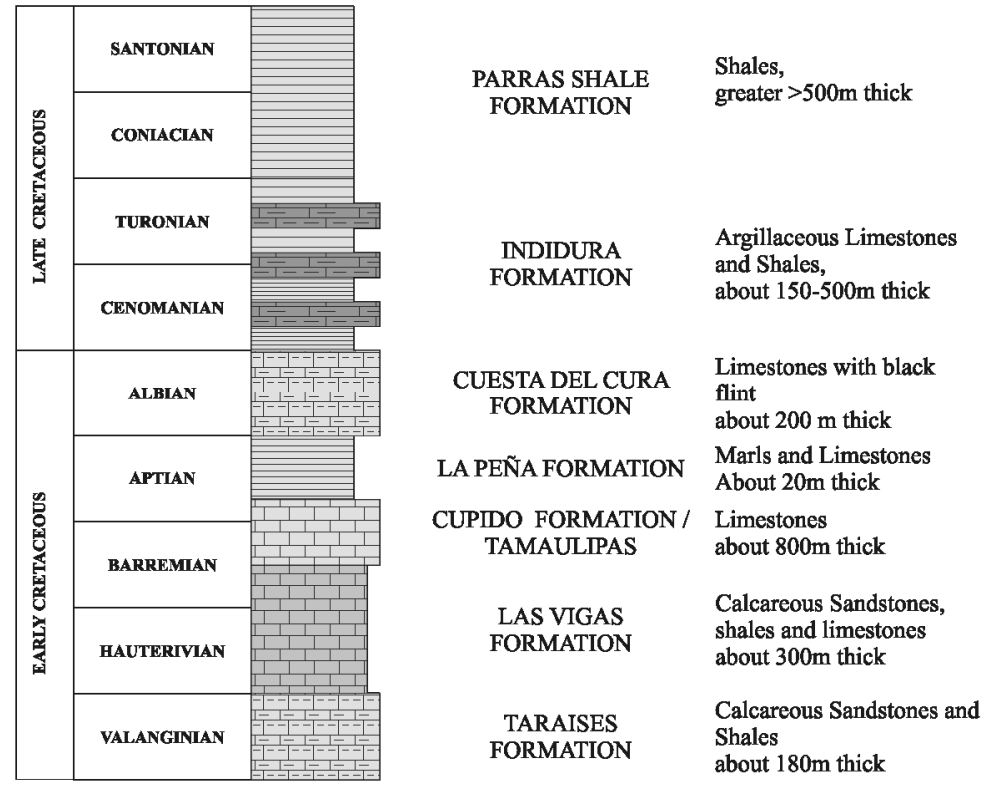

Figure 6 - 2. Generalized stratigraphic section (not drawn to scale due to lateral variations in thickness) of northeastern Mexico showing the main units present in the western part of the Sierra de Parras; data compiled from Imlay $(1936,1937)$.

Hauterivian and the early Barremian. The Cupido Formation (Imlay, 1937; Humphrey, 1949), overlies the Capulin Formation, and consists of dark gray to black limestones with rudists assigned to the Barremian. Deeper-water limestones and marls of Barremian to Aptian ages occur westward of the platform, and are commonly referred to as the Tamaulipas Formation (Ross et al., 1981). The La Peña Formation (Imlay, 1936, sensu Humphrey, 1949) overlies the Cupido limestones and comprises marl/shale facies with ammonites of Aptian age. They are succeeded by gray Aurora limestones (Imlay, 1940), grading into thinly-bedded, shaly limestones, gray shales and numerous chert stringers described as the Cuesta del Cura Limestone (Imlay, 1936, 1937) of late Albian age. The 
latter is overlain by the sedimentary sequence of the Indidura Formation, named and described by Kelly (1936) in the Las Delicias area of western Coahuila State. Kelly (1936, p. 1028-1029) defined the Indidura Formation as composed in its lower part of “...imperfectly consolidated buff shales containing many crystals of selenite. A thin transitional zone of intercalated platy limestone and shale is included with the Indidura. The highest beds observed are imperfectly stratified buff shales containing numerous veinlets of selenite"; he further added that "...the formation is about 100 feet thick and is divisible in three parts. The lower and upper divisions include the shale beds already mentioned. The middle division consists of interbedded rubbly, gray, pink and red argillaceous limestones, platy limestones and calcareous shale. Some fossils were collected from the lower division, but they are more numerous in the middle, where there are some fossiliferous horizons. Echinoidea, pelecypoda, and cephalopoda are the best represented classes". Shortly thereafter, Imlay (1936) further expanded the name Indidura Formation to rock sequences in the rest of the Sierra Madre Oriental. Jones (1938) later reported the fauna as of transitional character, and of Cenomanian-Turonian age.

According to Imlay (1936), the Indidura Formation of the Parras area is in gradational contact with the Cuesta del Cura Formation, and is marked by the appearance of gray shale beds. In that area, the Indidura Formation was estimated to reach a maximum thickness of 1,900 ft (578 m), and consists of interbedded black and gray shale (up to 75 $\mathrm{cm}$ ), with black to yellowish limestone (up to $35 \mathrm{~cm}$ ). The lowermost part of the Indidura Formation consists of an estimated 243 to 274 meters of powdery, and in places laminated, gray calcareous shales, with thin intercalations of dark gray limestones beds 
that are either lenticular or continuous. The middle part consists of an estimated 121 to 152 meters of finely laminated "salt and pepper" shales that alternate, particularly in the lower 20 meters, with sandy shales that contain lenses of brown selenite up to $80 \mathrm{~cm}$ thick. The uppermost part consists of 152 meters of platy, gray calcareous shales and brown to light-gray shaly limestones with some intercalations of sandy shales that contain abundant selenite crystals. The uppermost section of the rocks assigned to the Indidura Formation in the Sierra de Parras area is in sharp contact with the overlying Parras Formation. Based on its fossil content, Imlay $(1936,1937)$ assigned a CenomanianTuronian age to the Indidura Formation in the western part of the Sierras de Parras, and suggested that it might include Lower Coniacian. The Parras Shale (Imlay 1936,1937) is composed of black calcareous shale with interbedded dark gray siltstone, its age is uncertain due to the scarcity of diagnostic fossils.

\subsection{Samples and Laboratory Methods}

Samples of rock sequences attributed to the Indidura Formation were collected from three sections in the Sierra Madre Oriental, NE Mexico. These sites are found 1) in the Sierra de Las Delicias "the stratotype area" (Kelly, 1936); 2) in the canyon la Casita (Imlay 1936); and 3) near the town of Parras de la Fuente, Coahuila (Duque-Botero and Maurrasse, 2002b), see Figure 6 - 2 for localities. Thin sections were prepared, described, and characterized with the help of a polarized light microscope using Folk's (1980) classification scheme. Polished rock slabs and thin sections were acid etched following the technique described by Folk (1993), and were analyzed for imaging and semiquantitave chemical analysis with a SEM JSM-5900-LV. Samples were later 
described for intrinsic sedimentological characteristics and microstructures that are not observable with standard petrographic microscopes. Analyses for carbon/carbonate content were conducted on fresh samples using a LECO CR-412 analyzer, and results are presented as carbon percent $\mathrm{C}(\%)$ for dry weight bulk sample.

\subsection{Data and Results}

\subsubsection{Sedimentary and petrographic descriptions}

\subsubsection{Las Delicias (type locality area)}

As observed at the type locality selected by Kelly (1936), at the field scale the Indidura Formation is composed of interbeds of very-pale orange (10YR8/2) biocalcirudites and marls 10-30 cm thick. Macrofossils include abundant ammonites, echinoderms and pelecypods. The beds are rather stuctureless (Figure $6-3 \mathrm{~A}, \mathrm{~B}$ ), both at the macroscopic as well as the microscopic scales. Total obliteration of kinematically produced aqueous primary structures is consistent with high aerobic levels in the water column and within the upper part of the sedimentary column as attested by the rich epifauna (Brenchley and Harper, 1998).

Petrographically, calcite makes up an average of $80 \%$ of the main constituent with values as high as $93 \%$. Other minor constituents include pyrite cubes $(<8 \%)$, and rounded glauconite grains. Microsparite is the chief cement with less than $10 \%$ of the total rock groundmass recrystallized into sparry calcite. Benthic and planktonic foraminifera comprise no more than $5 \%$ of the total fossil assemblage. Most macrofossils and microfossils are filled with recrystallized sparry calcite (Figure 6 - 3 B,C). 


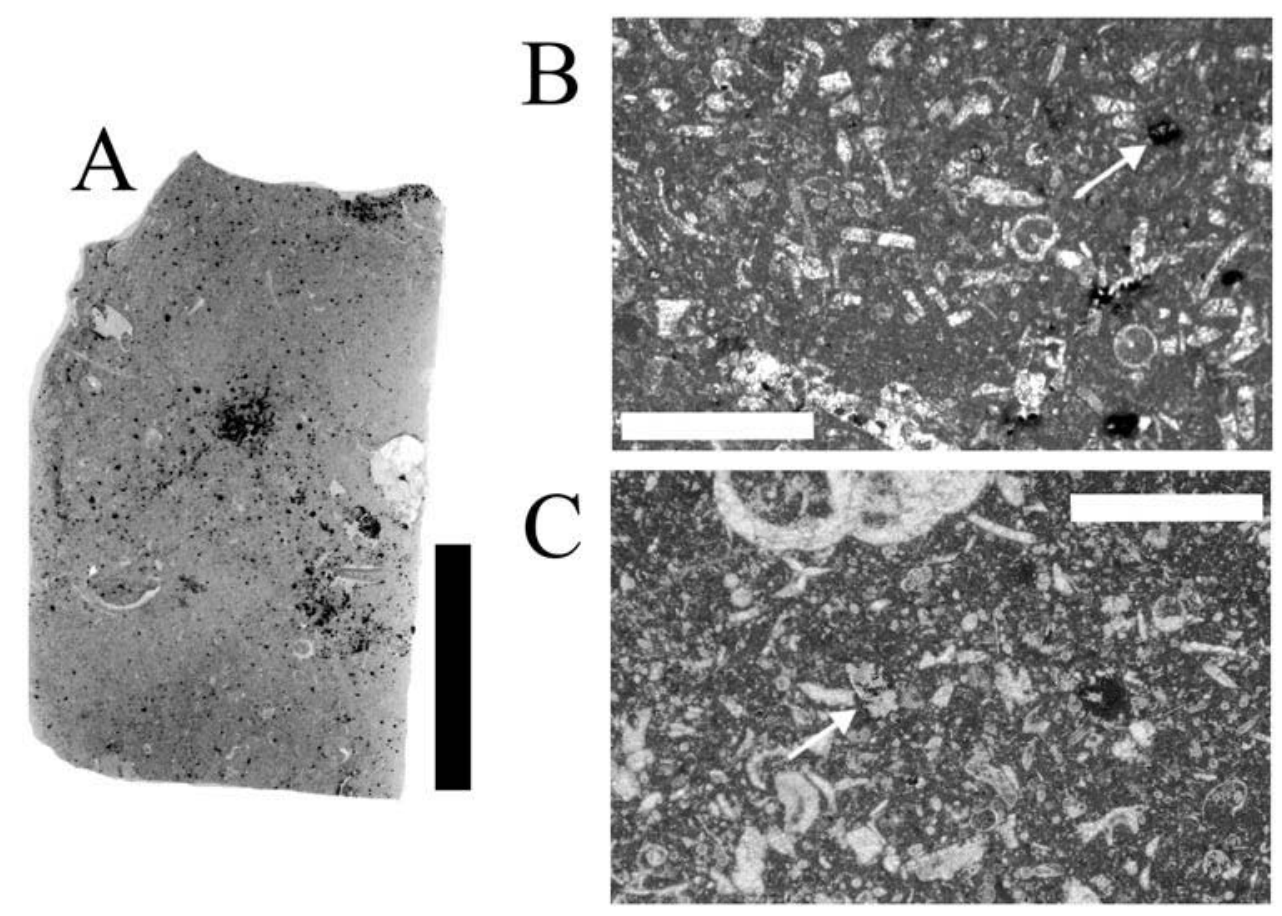

Figure 6 - 3. A) Petrographic thin section from Las Delicias: showing no primary sedimentary structures. Abundant fragments of echinoderms, gastropods and pelecypods molds are observed (scale bar $=1.5 \mathrm{~cm})$. B and C) Biocalcirudite microphotographs (plain light). Microsparite is the predominant cement, recrystallized echinoderm and gastropod molds make up most of the rock. Arrow in (B) points to pyrite grains, in (C) to glauconite grains (B and C scale bar $=500 \mu \mathrm{m}$ ).

\subsubsection{La Casita Canyon}

Rocks assigned to the Indidura Formation at the La Casita canyon are composed of 3 to $30 \mathrm{~cm}$-thick interbeds of pale yellowish brown (10YR6/2) biocalcilutites and olive gray (5Y3/2) shales. Macroscopically the beds exhibit no internal lamination. Closer observation reveals extensive burrowing (Figure 6 - 4 A) that may have obliterated any primary subaqueous structures that could have been associated with sedimentation. Although no benthic fossils were found, such biogenically induced isotropic fabric is consistent with aerobic bottom waters (Brenchley and Harper, 1998) that allowed epibenthos and inbenthos colonization with subsequent destruction of initial laminae. 
Petrographically, clay minerals are the dominant constituents, with an average of $68 \%$ and a maximum of $98 \%$. Carbonate components can reach values up to $50 \%$ of the rock, as recrystallized foraminifera and calcitized radiolarians, which are concentrated in burrow-filling structures (Figure 6 - 4 B,C), and micrite is the main cement.
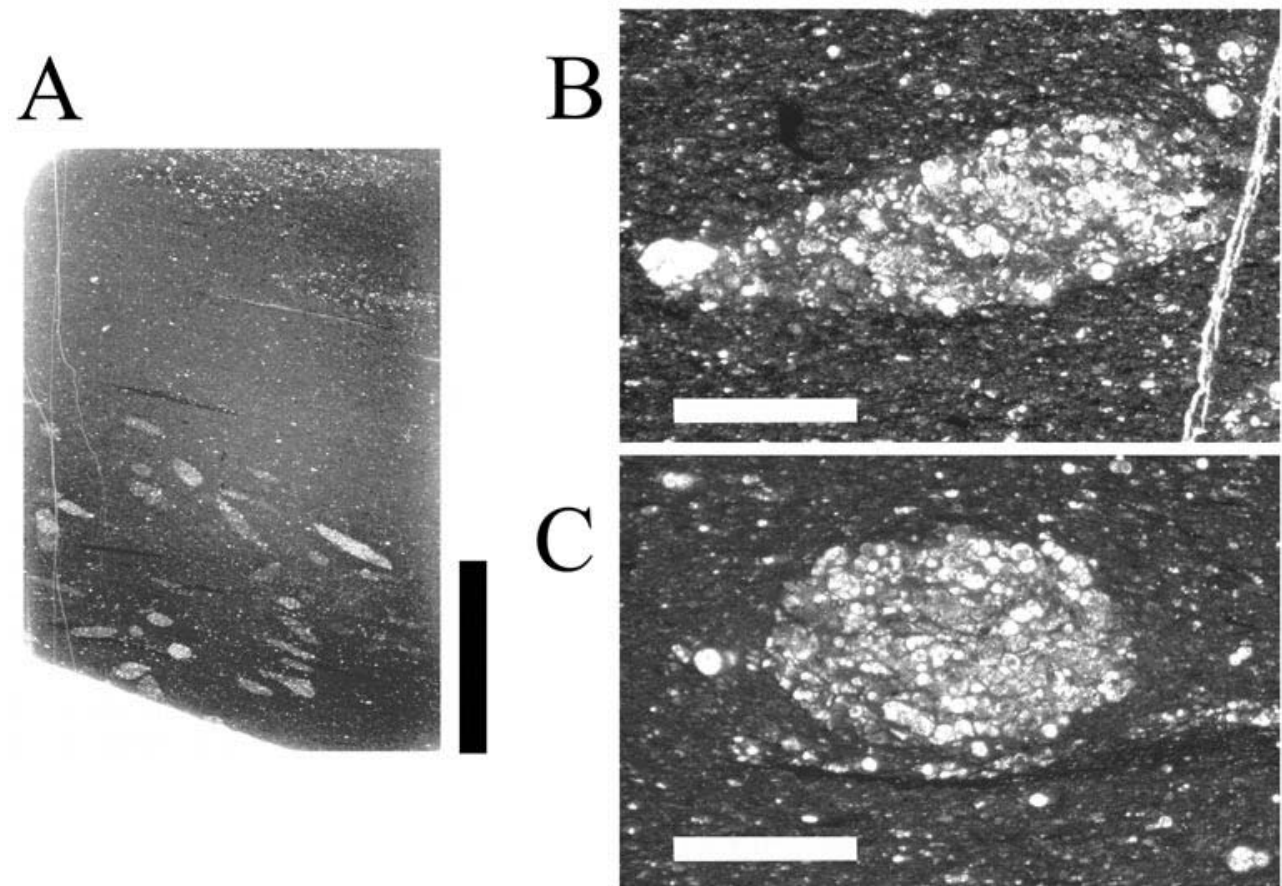

Figure 6 - 4. A) Petrographic thin section from La Casita: no laminations or original internal features are observed, small burrows $<2 \mathrm{~mm}$ in diameter are seen (scale bar $=1.5 \mathrm{~cm}$ ). B and C) Biocalcilutite microphotographs (plain light). Filled burrows contain planktonic foraminifera and few radiolarians. Some microfossils are scattered outside burrows (B and C scale bar $=500 \mu \mathrm{m}$ ).

\subsubsection{Parras de la Fuente area}

At a locality west of the town of Parras de la Fuente, in the northwestern flank of the Sierra de Parras (GPS coordinates; $\left.25^{\circ} 26^{\prime} 17.9^{\prime \prime} \mathrm{N} ; 102^{\circ} 12^{\prime} 54.7^{\prime \prime} \mathrm{W}\right)$; the sequence referred to as the Indidura Formation consists of interbedded light olive gray (5Y6/1) and brownish black to olive black (5YR2/1 - 5Y2/1) calcareous shales (5-200 cm thick), and marly biocalcilutites $(8-100 \mathrm{~cm}$ thick $)$. At the field-scale, the sequence is monotonous and 
contains only scarce inoceramids and few ammonites, and both types of rocks reveal the presence of continuous and persistent 1-2 mm thick fine laminae (Figure $6-5 \mathrm{~A}$ ). At the microscopic scale, petrographic studies of the thin sections reveal that laminae are formed by intercalation of even-parallel to wavy-parallel, light and dark sub-units that resemble varve deposits. Light laminae are mainly composed of calcite-filled "microooids" or "microspheres" between 5 and $100 \mu \mathrm{m}$ with a median size of $40 \mu \mathrm{m}$ (Figure 6 $5 \mathrm{~B}, \mathrm{C})$. These granular components are less abundant in the dark laminae that also include few scattered planktonic foraminifera, and scarce radiolarians. In addition to the microspheres, the main components of the matrix include 30 to $50 \%$ undifferentiated
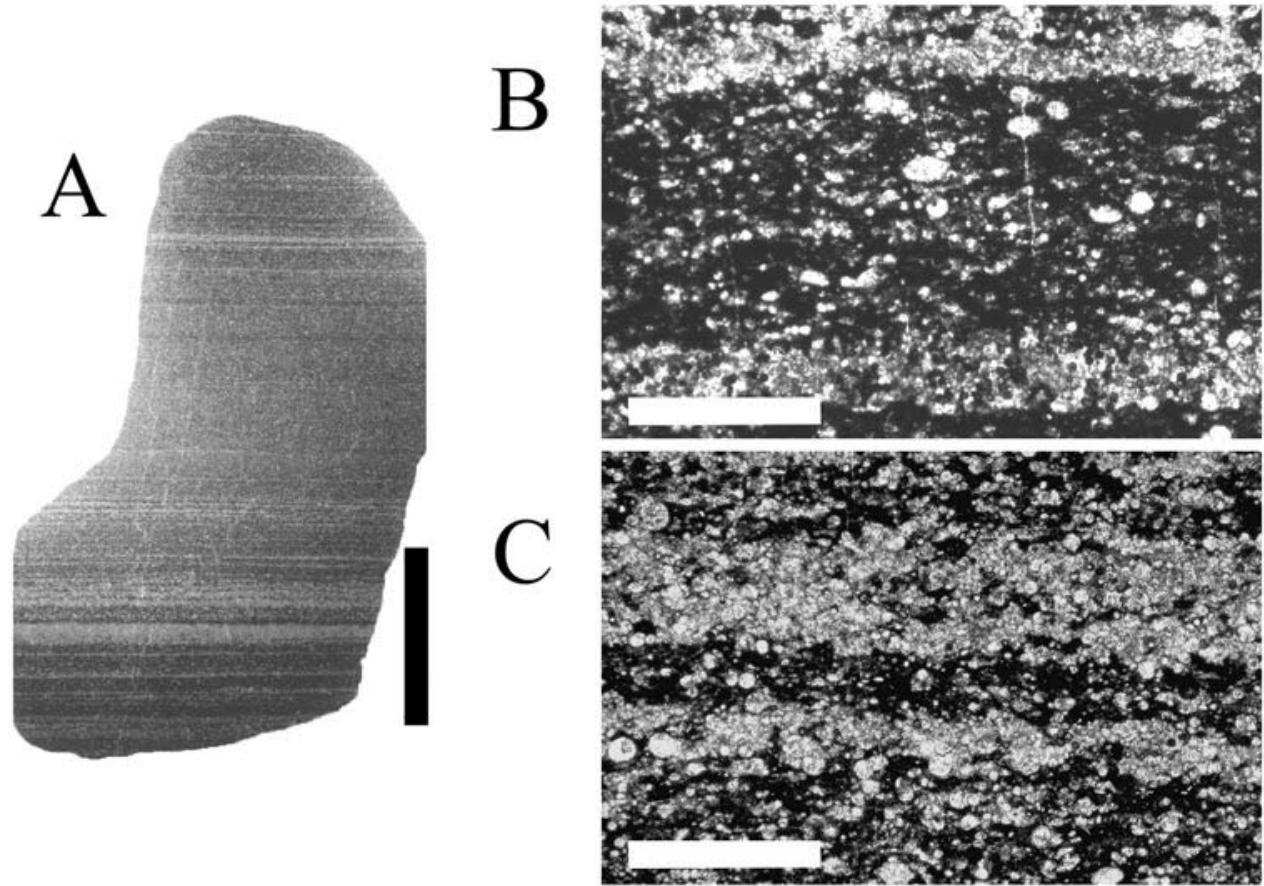

Figure 6 - 5. A) Petrographic thin section from Parras area: conspicuous parallel laminations clearly form couplets that resemble 'varves'. Laminae are even-parallel and are classified as very thin laminae $<3 \mathrm{~mm}$ (scale bar $=1.5 \mathrm{~cm}$ ). B and C) Biocalcilutite microphotographs (plain light), laminations at this magnification when compared with the macro level are not continuous, but instead they form a wavy pattern that is characterized by lower to higher concentration of 'microspheres' (B and C scale bar $=500 \mu \mathrm{m})$. 
clay-size particles, up to $5 \%$ scattered framboidal pyrite aggregates, and microsparite is the main cement, although microsparite is found in microfractures.

Microscopic observations also reveal that the conspicuous laminae observed at the macroscopic scale are in fact not continuous; they occur as uneven discrete units with pinch and swell structures. The types of structures associated with the "microspheres" are similar to those shown by Kazmierczak and Kempe (1992), Kazmierczak et al. (1996), Tribovillard (1998), Kazmierczak and Altermann (2002), and Tribovillard et al. (2000) that have been interpreted to be of bacterial origin.

\subsubsection{Scanning Electron Microscope (SEM) descriptions}

Backscatter and secondary electron imaging of samples from Parras de la Fuente corroborate and further define the microstructures observed in the petrographic analyses. As stated previously, lamination does not occur in samples of either Las Delicias or the La Casita sites. The shales and biocalcilutites from the Parras area are predominately composed of distinct microspheres that are consistently spherical, semi-spherical and ovoid in shapes (Figure 6 - $6 \mathrm{H} \mathrm{-} \mathrm{M).} \mathrm{They} \mathrm{occur} \mathrm{as} \mathrm{scattered} \mathrm{individuals,} \mathrm{and} \mathrm{in}$ aggregate strings of microspheres (Figure $6-6 \mathrm{~B}, \mathrm{~F}$ ). Most of the microspheres regularly exhibit a 3 to $5 \mu \mathrm{m}$-thick rim of microcrystalline calcite reminiscent of a "test".

Microspheres are made up of single or multiple crystals of sparry calcite aggregates that are analogous to the internal structures of strings of attached cells described by Gobulic and Campbell (1981), and to cell-like structures (Kazmierczak and Krumbein, 1983; 

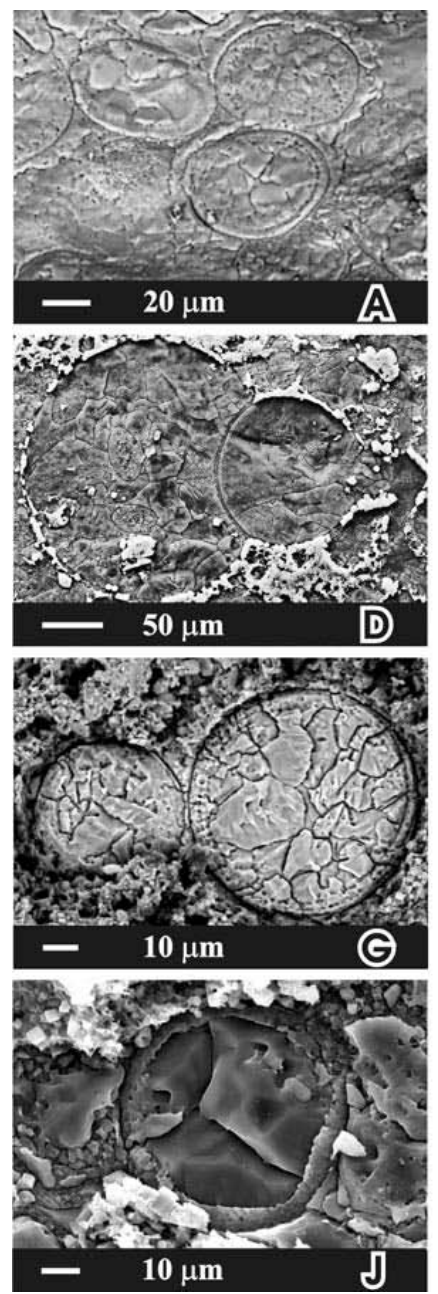
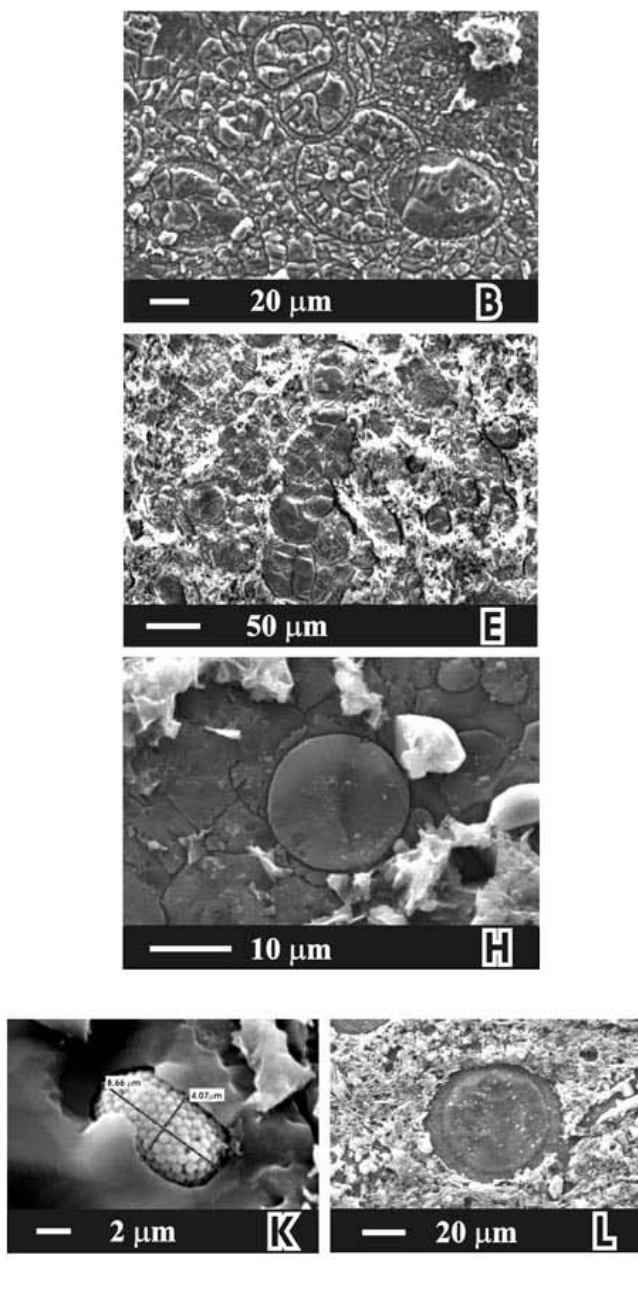
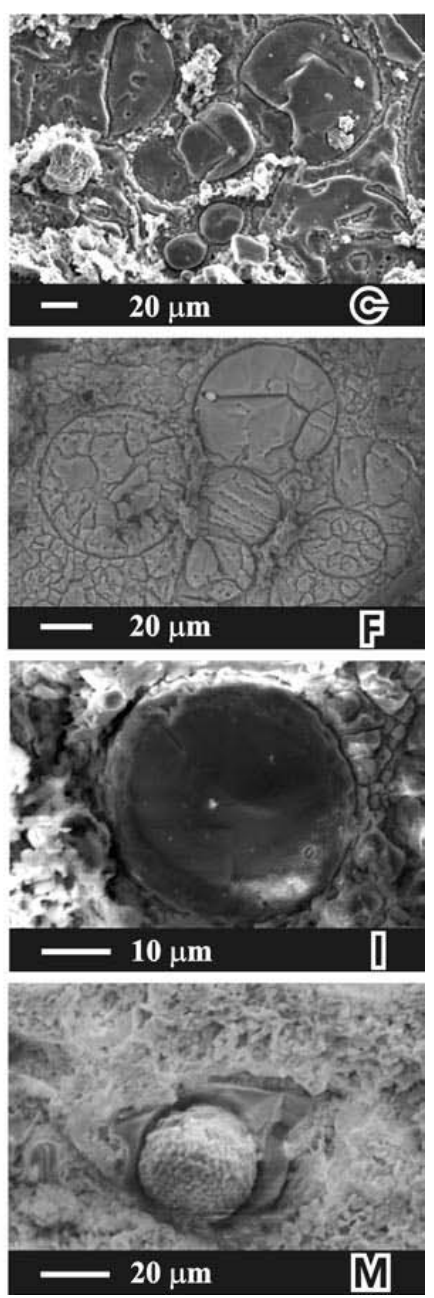

Figure 6 - 6. Scanning Electron Microscope images. High magnification allows us to show that microspheres have spherical (A, C, D, G, H, I, J, L), semispherical and ovoid shapes (B, C, E), and consistently exhibit a 3 to $5 \mu \mathrm{m}$ rim of microcrystalline calcite that is reminiscent of a test. Microspheres are made up of single $(\mathrm{C}, \mathrm{H}, \mathrm{I}, \mathrm{L})$ or multiple crystals of sparry calcite $(\mathrm{A}, \mathrm{B}, \mathrm{D}, \mathrm{E}$, $\mathrm{F}, \mathrm{G}, \mathrm{J})$ and are found isolated $(\mathrm{H}, \mathrm{I}, \mathrm{J}, \mathrm{L})$ or as aggregates that resemble strings of attached cells (A, B, C, D, E, F, G). K and M are pyrite framboids. $\mathrm{K}$ is a close up of a pyrite framboid found inside $\mathrm{L}$ (arrow), and $\mathrm{M}$ is a framboid in the matrix.

Kazmierczak and Altermann, 2002) interpreted to be the result of the calcification of

living cyanobacteria. Some of these strings may resemble heterohelicid planktonic

foraminifera in edge view, but we rule out this possibility because the shell structure is

different, and it is unlikely that biserial foraminifers would consistently orientate in such

a way as to have only the edge view exhibited in both SEM and petrographic images. 
SEM semi-quantitative EDS analyses of samples from Parras de la Fuente and Canyon la Casita supports the petrographic observation of a high clay content of these sites. Data for the Canyon la Casita shows a high silica and aluminum content in the matrix (Figure 6 - 7). The observed pattern is characteristic of minerals of clastic origin and most probably of the clay group, consistent with the EDS analysis of high silica and aluminum. The matrix at Parras de la Fuente is composed mainly of microcrystalline calcite and minor amounts of framboidal pyrite (Figure 6-8).
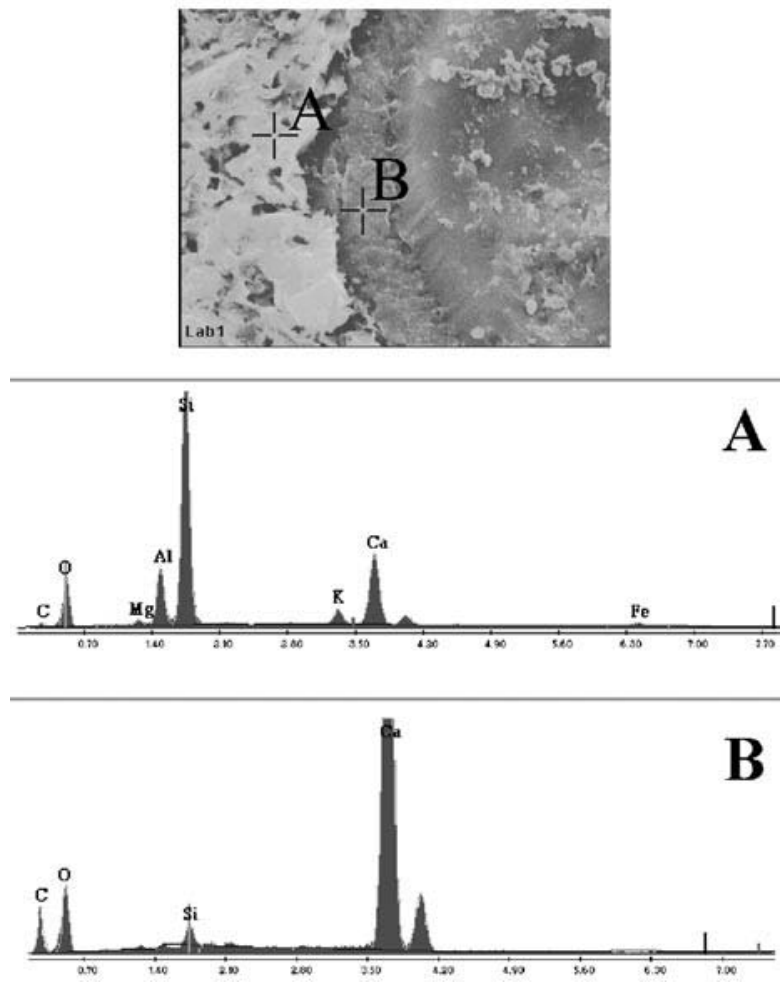

Figure 6 - 7. SEM-EDS image and semi-quantitative chemical analysis from Parras de la Fuente. Matrix (A) analysis shows higher abundance of silica, aluminum, potassium and iron when compared to 'microspheres' (B). 


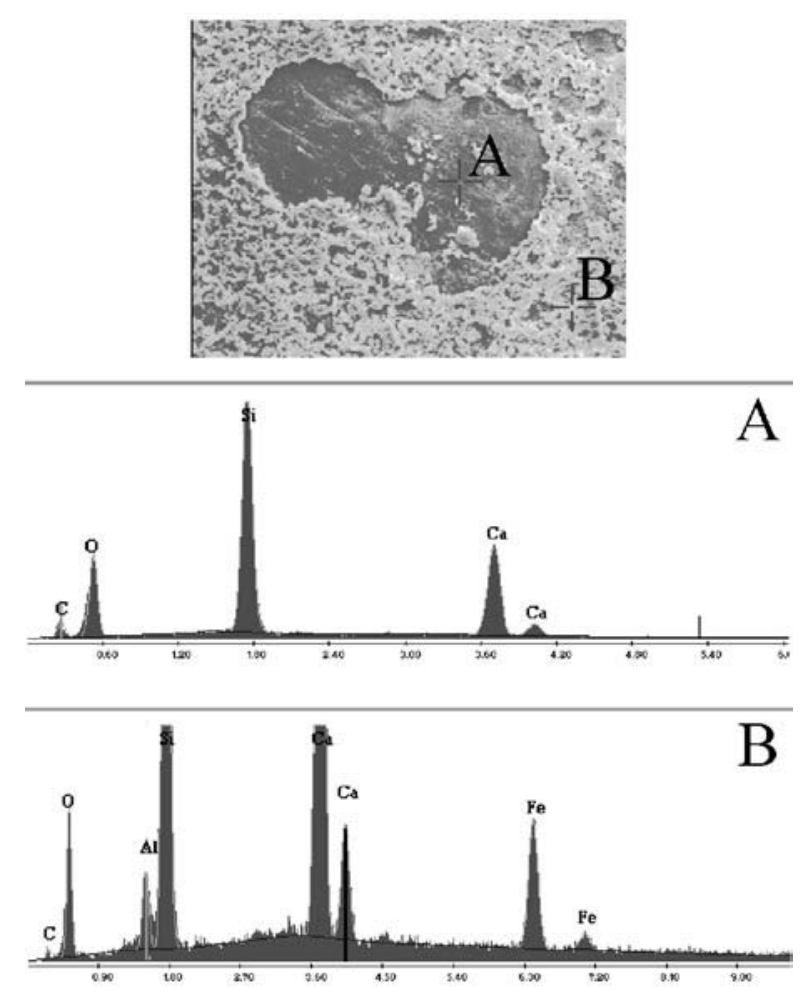

Figure 6 - 8. SEM-EDS image from Canyon la Casita. Foramifer (A) analysis shows high abundance of silica indicating silicification. Matrix (B) shows silica, aluminum and iron being abundant in the matrix; the latter two are not present inside microfossils.

\subsubsection{Carbon/Carbonate analysis}

Samples from the three sections were analyzed for their relative percentages of organic and inorganic carbon, and the results are presented as percentage (\%) of total dry weight of the bulk sample (Table 6-1). The data clearly show strong and marked differences in the carbon/carbonate contents between the three areas (Figure 6 - 9).

Results from Las Delicias (stratotype area) yield carbonate percentages that vary between 48 and $90 \%$, and TOC between 0.73 and $1.9 \%$, while the non-carbonate fraction ranges from 4.5 to $50 \%$ (Figure 6 - 9, Table 6- 1). These values are consistent with the petrographic observation of high carbonate content. Relatively low TOC is also in 
agreement with our previous inference of a well-oxygenated bottom that not only sustained a rich benthic fauna that homogenized the sediments, but also caused oxidation of organic matter and enhanced microbial degradation (Andersen and Kristensen 1992).

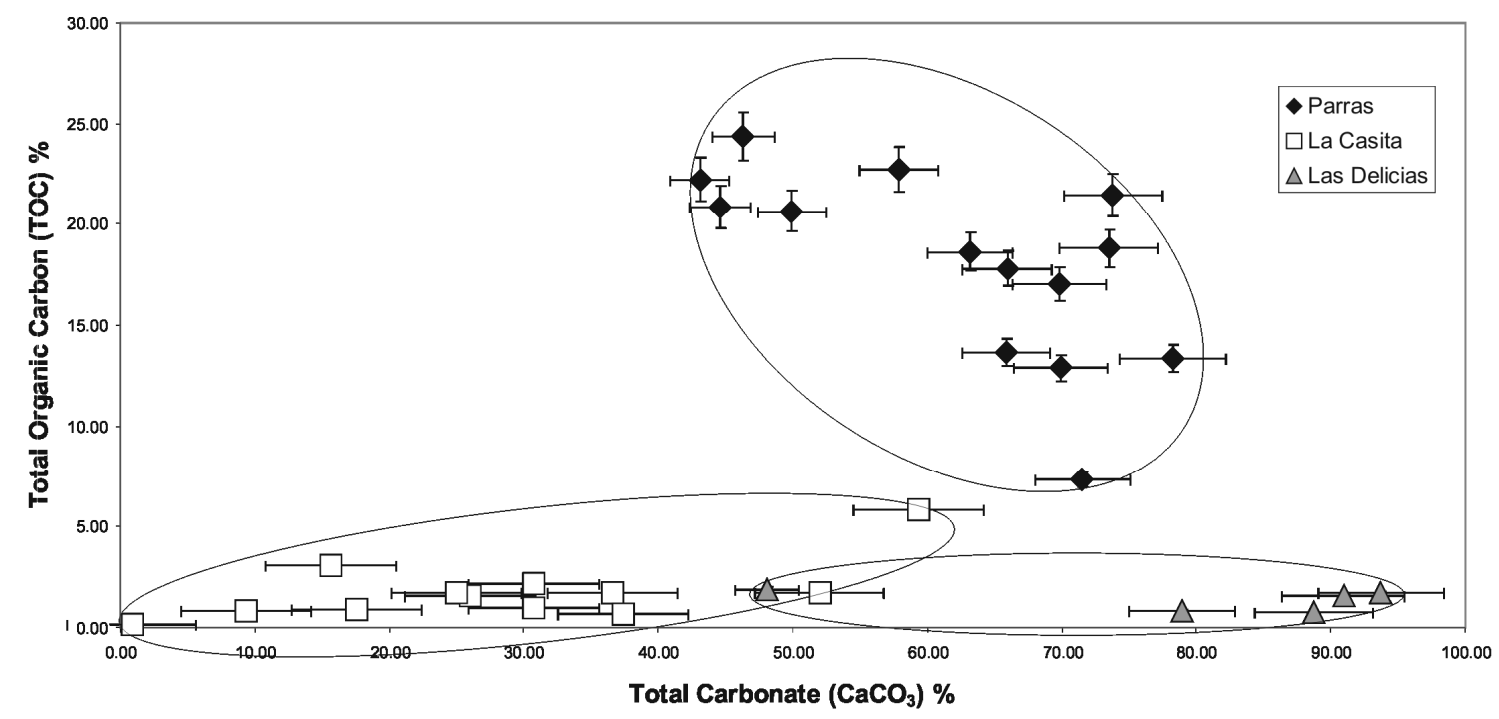

Figure 6 - 9. Total Organic Carbon (TOC) and Total Carbonate $\left(\mathrm{CaCO}_{3}\right)$ contents. Samples from the three sections show distinct proportions indicating that environmental conditions greatly differed over the accumulation area. High TOC values correlate with low bioturbation as see in Figure 6.5 , while lower values are associated with distorted primary sedimentary structures and burrowing (Figs. 6.3 and 6.4).

Results from Canyon la Casita yield carbonate percentages that vary between 0.8 and $59.3 \%$, and TOC between 0.1 to $5.8 \%$, but most consistently below $2 \%$. As deduced from the TC values shown in Table 6- 1, the non-carbonate fraction ranges from 34.8 to 98.9\%. Since TOC values vary independently from total non-carbonate fraction, they imply that the influx of terrigenous supply did not control the preservation of the organic matter (Canfield, 1992). Although total carbonate has been affected by diagenesis, as shown by the calcified radiolarian tests, TOC values being weakly covariant with the carbonate content suggest that the triggering factors that controlled carbonate producers 
also affected the total biomass production that caused enhanced organic carbon accumulation and/or preservation.

\begin{tabular}{|c|c|c|c|c|}
\hline & Sample & Total Carbon (wt\%) & Total Carbonate $\quad\left(\mathrm{wt}^{2} \% \mathrm{CaCO}_{3}\right)$ & TOC (wt\%) \\
\hline \multirow{14}{*}{ Parras de la Fuente } & MXF-1 & 27.40 & 43.08 & 22.23 \\
\hline & MXF-2A & 15.95 & 71.55 & 7.36 \\
\hline & MXF-2C & 26.18 & 44.60 & 20.83 \\
\hline & MXF-3 & 21.55 & 65.90 & 13.64 \\
\hline & MXF-4A & 22.78 & 78.29 & 13.38 \\
\hline & MXF-4B & 21.27 & 69.92 & 12.88 \\
\hline & MXF-5 & 29.95 & 46.32 & 24.39 \\
\hline & MXF-6 & 25.41 & 69.82 & 17.03 \\
\hline & MXF-7 & 25.73 & 65.96 & 17.81 \\
\hline & MXF-8 & 30.30 & 73.80 & 21.44 \\
\hline & MXF-N-14 & 27.64 & 73.48 & 18.82 \\
\hline & MXF-N-15 & 26.19 & 63.16 & 18.61 \\
\hline & MXF-N-16 & 26.64 & 49.94 & 20.65 \\
\hline & MXF-N-18 & 29.68 & 57.87 & 22.74 \\
\hline \multirow[t]{12}{*}{ Canyon La Casita } & MXF-N-1 & 7.98 & 51.97 & 1.74 \\
\hline & MXF-N-2 & 4.73 & 26.04 & 1.61 \\
\hline & MXF-N-3 & 4.94 & 15.69 & 3.06 \\
\hline & MXF-N-4 & 0.28 & 0.84 & 0.18 \\
\hline & MXF-N-5 & 1.95 & 9.37 & 0.83 \\
\hline & MXF-N-7 & 6.11 & 36.63 & 1.71 \\
\hline & MXF-N-8 & 4.70 & 30.74 & 1.01 \\
\hline & MXF-N-9 & 4.74 & 25.00 & 1.74 \\
\hline & MXF-N-10 & 3.02 & 17.61 & 0.91 \\
\hline & MXF-N-11 & 5.87 & 30.73 & 2.18 \\
\hline & MXF-N-12 & 12.98 & 59.31 & 5.86 \\
\hline & MXF-N-13 & 5.13 & 37.38 & 0.64 \\
\hline \multirow[t]{5}{*}{ Las Delicias } & MXF-N-20 & 10.30 & 78.89 & 0.83 \\
\hline & MXF-N-21 & 7.68 & 48.08 & 1.91 \\
\hline & MXF-N-24 & 12.98 & 93.74 & 1.73 \\
\hline & MXF-N-25 & 11.39 & 88.73 & 0.74 \\
\hline & MXF-N-26 & 12.51 & 90.97 & 1.59 \\
\hline
\end{tabular}

Table 6- 1. Carbon analysis values are expressed as carbon percent $\mathrm{C}(\%)$ for dry weight bulk sample, except in the central column where carbonate percentages of each sample are indicated ( $\mathrm{TOC}=$ Total organic carbon).

Results from Parras de la Fuente area yield high carbonate percentages with values varying between $43 \%$ and $78.3 \%$, a much higher range than those observed at Canyon la Casita, but within the range of values observed at Las Delicias. TOC values are also the 
highest out of the three areas, with values between 7.3 and $24.9 \%$, and commonly higher than 20\%. The non-carbonate fraction varies between 4.7 and 34.6\% (Figure 6 - 9, Table 6- 1) and independently from the TOC values, as discussed for the site at la Casita. The high TOC values coincide with sedimentary facies with minimum bioturbation, and therefore where laminae and original fabric are preserved.

\subsection{Discussion and Conclusions}

Assuming coevality of the facies between the different sites at Las Delicias (type area), Canyon la Casita and Parras de la Fuente, their high variability in sediment type, faunal content and TOC, underscores non-uniform environmental conditions over the Mexican Platform.

Comparison of the TOC values versus all other constituents from the areas studied shows great variation in the Corganic contents ( $7.3 \%$ to $24.9 \%$ at Parras) that can be interpreted to be the result of differences in oxygenation level, productivity and preservation of the organic matter. Based on the macrofaunal composition of the facies that occurs at Las Delicias, it is evident that waters at that site remained more oxygenated. Thus, the lower TOC values $(0.73-1.9 \%)$ in that area may be indicative of higher oxic level and faster degradation of organic matter that may have been produced. Although we cannot preclude that organic production was effectively lower, conditions conducive to degradation of organic matter may have been further enhanced by metazoan benthos bioturbation, which can stimulate microbially mediated decomposition reactions (Andersen and Kristensen, 1992). 
The sedimentary sequence studied at Parras has been commonly assigned to the Indidura Formation, but our study provides further evidence to corroborate previous suggestions (Imlay, 1938) that lateral correlation with the stratotype at La Delicias remains unclear because the two types of facies are quite different. In fact, their lateral continuity is undocumented in either area, and this issue was raised by Imlay (1938, p. 1692) who noted that “...Comparing the highly fossiliferous Indidura formation in central Coahuila with the un-fossiliferous so-called Indidura formation in areas off-shore from the Coahuila Peninsula, the question arises as to whether they should be recognized by the same name." This discrepancy between the facies is further supported by the results of our work showing that various parameters such as field-scale observable rock characteristics, microfacies, as well as organic carbon, and carbonate contents show fundamental dissimilarities usually associated with lithostratigraphic units of next higher rank to formation (NACSN, 1983). Thus, as compared to the type area, usage of the term "Indidura Formation" in the Parras Mountains is for practical purpose, and is therefore in a broad sense (sensu lato) based on precedence, until the issue is further addressed in our ongoing investigation. By analogy with structures previously reported to be bacterially generated, microgranules that make up the main constituents of the laminae in the sequence at Parras are interpreted to represent deposits produced by bacterial activities that accumulated as bacterial mats. In fact, the laminae are identical to sedimentary laminae described by Schieber (1986), O'Brien and Slatt (1990) and O'Brien (1996) in Paleozoic shales, and associated rocks. The presence of very few inoceramids, the absence of other benthic organisms, and low level of bioturbation throughout the sequence at the Parras site are corroborative evidence that dysoxic to anoxic bottom 
water prevailed within the time interval studied. Differences between the sites are interpreted to be related to paleogeophysiographic irregularities of the Mexican Platform, and associated differences in paleoceanographic conditions that controlled variabilities in the sedimentary record.

In fact, sedimentary and fossil structures similar to those identified in the Parras sediments can be equated to fossilized counterparts of present cyanobacterial and microbial communities (Tribovillard, 1998; Tribovillard et al., 2000). Similarly, differential accumulation rates of the bacterial masses gave rise to pinch and swell structures (Schieber, 1986). The scarcity or consistent absence of both planktonic and benthic fauna also indicates competitive exclusion caused by perennial dominance of bacterial colonies throughout the water column.

Perhaps, in addition to special local physiographic factors inherent to the Mexican Platform, upward flux of nutrients that sustained high cyanobacterial productivity for such extended period may have been influenced by global forcing factors associated with the overall warm and equable climates that prevailed at these times. Warmer global temperatures would certainly increase evaporation, and given the proper regional physiographic conditions would consequently induce generation of thermohaline warm saline bottom water (WSBW), which in turn increased upwelling. Such mechanism can enhance higher productivity, and maximize the storage of mass quantities of organic matter in worldwide events (Jenkyns et al., 1994; Norris et al., 2001). 
We conclude that close analogs to such microbial production are those of planktonic blooms of calcifying cyanobacteria (Robbins and Blackwelder, 1992; Robbins et al., 1997; Yates and Robbins 1998, 2001), and non-calcifying cyanobacteria (Carpenter and Romans, 1976; Carpenter, 1983) reported as common occurrences in present oceans. In the Indian Ocean, for instance, differences in stratification of the near-surface waters caused by the monsoon periods control the alternant of nitrate-limited cyanobacterial blooms versus normal phytoplankton productivity (Devassy et al., 1978; Sen Gupta and Naqvi, 1984). When phytoplanktons are able to thrive they limit bacterial colonies, which then become more dispersed. We believe that a similar cyclic production of picoplankters may explain the presence of dark laminae 'cyanobacterial rich' (anoxic conditions) and light laminae 'cyanobacterial poor' (dysoxic conditions). In addition, unusually high bacterial productivity may explain enhanced oxygen depletion recorded in the depositional environment of the Parras area, where relatively low-oxygen concentrations that existed in the "Mid" Cretaceous oceans (Tatsumi et al. 1998) would further exacerbate the conditions in that area as compared to the other sites.

Another factor to consider is the possible role played by iron in these environments, as experiments by Coale et al. (1996) have demonstrated that primary productivity can be highly affected by the introduction of even small quantities of Fe into the upper water column, causing oceanic phytoplankton blooms. The pattern of TOC fluctuation in the area studied suggests that a similar influence may have played an important role during the accumulation of the Corganic-rich sediments on the northeastern Mexican basin at that time. Several scenarios can be considered to provide likely sources for Fe, e.g. wind- 
blown particles, enhanced hydrothermal activity, and riverine input. We believe that a wind-blown provenance is less likely, because of the limited areal extent of deserts during the Cretaceous, as attest only few occurrences of eolian deposits (China, Canada, Africa and Brazil). Such record is compatible with expected global response to warm and equable climates during "green house conditions" (Loope et al., 1998; Bird, 1984).

Enhanced hydrothermal activity can be a relevant factor at that time, which corresponds to increased sea floor spreading activity, as well as emplacement of the latest stages of Large Igneous Provinces (LIP's) such as the Ontong Java and Caribbean plateaus (Sinton and Duncan, 1997; Kerr, 1998). Thus, increasing flux of iron in the ocean waters may have permitted large-scale phytoplankton blooms in areas where Fe acted as a biolimiting nutrient. In such cases, intensified supply of organic matters and decomposition through the water column would also intensify oxygen consumption, hence reducing available $\mathrm{O}_{2}$, conditions that will be optimum for generation of Corg-rich deposits. Although this is a likely process that may have contributed to the cyanobacterial blooms, it does not explain the cyclical lamination and larger-scale interbeds observed in the Indidura Formation (s.1).

Riverine input that may reflect a seasonal component seems the most likely triggering mechanism to explain the high frequency of changes recorded by the laminae. As observed in present environments, periodic influx of fresh water rich in clays, dissolved iron and other nutrients, could have induced conditions in the "Mid Cretaceous" where cyanobacteria were able to thrive almost at the exclusion of all other organisms. In 
particular, the situation of the basin associated with the facies at Parras would have been comparable to patterns of riverine iron influx and its critical role in the accumulation of sapropels in the Mediterranean Sea. In the latter case, the pattern fluctuated as the head and catchments areas of the Nile shifted due to changes in the position of the Intertropical Convergence Zone (Krom et al., 2002). By analogy, paleogeographic conditions in the Gulf of Mexico/ Northeastern Mexico region may have been conducive to similar periodic incursions of iron-rich or iron-poor riverine waters in the existing basin associated with the Mexican Platform. In combination with a fortuitous nitrogen limitation, these fluctuating iron supplies could have created favorable conditions for periodically enhanced cyanobacterial blooms that produced high concentrations of Corg-rich detritus. Consequently, low dissolved $\mathrm{O}_{2}$ further allowed alternating accumulation of Corganicrich sediments in a recurrent mode that generated the sedimentary features or varve-like laminae and beds couplets observed in the succession of the Indidura Formation (s.l) at Parras.

\subsection{Acknowledgements}

We thank José Guadalupe López-Oliva for invaluable assistance and expertise in the field in November of 2002. F.M. also acknowledges field assistance from Ricardo BarragánManzo for an earlier reconnaissance work in the area. Many thanks to Barbara Maloney at the Florida International University Center for Analytical Electron Microscopy (FCAEM), for her assistance and collaboration with SEM images and analyses, and Diane Pirie for her graciousness and patience in keeping the CR-412 Carbon Analyzer in working condition. The manuscript benefited from the careful reviews of N. P. 
Tribovillard, C.R.C. Paul and an anonymous reviewer, as well as from editing and comments of M. A. Lamolda. This work was partially supported by the Glenn A. Goodfriend Memorial funds, and other private sources. Special thanks to the people of Murcia and Caravaca who supported the Conference on Bioevents, and provided financial assistance to attend the conference in Caravaca. 


\subsection{References}

Andersen, F.O. and Kristensen, E., 1992, The Importance of Benthic Macrofauna in Decomposition of Microalgae in Coastal Marine Sediment: Limnology and Oceanography, v. 37, p. 1392-1403.

Arthur, M.A., Jenkyns, H.C., Brumsack, H.J., and Schlanger, S.O., 1990, Stratigraphy, geochemistry, and paleo-oceanography of organic carbon-rich Cretaceous sequences, in Ginsburg, R.N. and Beaudoin, B., eds., Cretaceous resources, events and rhythms; background and plans for research: Dordrecht-Boston, D. Reidel Publishing Company, p. 75-119.

Arthur, M.A. and Premoli Silva, I., 1982, Development of widespread organic carbonrich strata in the Mediterranean Tethys, in Schlanger, S.O. and Cita, M.B., eds., Nature and origin of Cretaceous carbon-rich facies: London, Academic Press Inc., p. 7-54.

Barragan, R., 2000, Ammonite biostratigraphy, lithofacies variations, and paleoceanographic implications for Barremian-Aptian sequences of northeastern Mexico Ph.D. Dissertation: Florida International University, 277 p.

Barragan-Manzo, R. and Maurrasse, F.J., 2000, Transition Cupido-La Pena Formations in Northeastern Mexico: Enhanced apparent depth due to anoxic conditions, EOS Transactions AGU, 81 (48), Fall Meeting Supplement p. A115-A116.

Bird, E.C.F., 1984, Dune calcarenite and shore platforms at Cape Otway, Victoria: Victorian Naturalist, v. 101, p. 74-79.

Borrego, A.G., Hagemann, H.W., Blanco, C.G., Valenzuela, M., and Suarez de Centi, C., 1996, The Pliensbachian (Early Jurassic) "anoxic" event in Asturias, northern Spain; Santa Mera Member, Rodiles Formation: Organic Geochemistry, v. 25, p. 295-305.

Bralower, T.J., Premoli Silva, I., Malone, M.J., et al. 2002, Shipboard Scientific Party. Proceedings ODP, Initial Reports, 198: 1-84. Available from World Wide Web: http://www-odp.tamu.edu/publications/198 IR/198ir.htm.

Brenchley, P.J. and Harper, D.A.T., 1998, Palaeoecology; ecosystems, environments and evolution: London, Chapman \& Hall, p. 402.

Burrows, R.H., 1910, Geology of northern Mexico: Boletin de la Sociedad Geologica Mexicana, p. 85-103.

Canfield, D.E., 1992, Organic matter oxidation in marine sediments, in Wollast, R., Mackenzie, F.T., and Chou, L., eds., N, P and S biochemical cycles and global 
change, Melreux, NATO advanced research workshop on Interactions of C: Berlin, Springer-Verlag, p. 333-363.

Carpenter, E.J., 1983, Physiology and ecology of marine planktonick Oscillatoria (Trichodesmium): Marine Biology Letters, v. 4, p. 69-85.

Carpenter, E.J. and Romans, K., 1976, Marine Oscillatoria (Trichodesmium): explanation for aerobic nitrogen fixation: Science, v. 191, p. 1278-1280.

Coale, K.H., Tanner, S., Chavez, F.P., Ferioli, L., Sakamoto, C., Rogers, P., Millero, F., Steinberg, P., Nightingale, P., Cooper, D., Cochlan, W.P., Landry, M.R., Constantinou, J., Rollwagen, G., Trasvina, A., Kudela, R., Johnson, K.S., Fitzwater, S.E., and Gordon, R.M., 1996, A massive phytoplankton bloom induced by an ecosystem-scale iron fertilization experiment in the equatorial Pacific Ocean: Nature, v. 383, p. 495-501.

Devassy, V.P., Bahattathiri, P.M.A., and Qasim, S.Z., 1978, Trichodesmium phenomenon: Indian Journal of Marine Sciences, v. 7, p. 168-186.

Duque-Botero, F. and Maurrasse, F.J.-M.R., 2002a, Spatial and Temporal Variations of the Indidura Formation (Cenomanian-Turonian) in Northeastern Mexico, Coahuila State: Eos Transactions AGU, v. 83(47), Fall Meeting Supplement, Abstract PP11A-0306.

Duque-Botero, F. and Maurrasse, F.J., 2002b, Microbial (cyanobacteria?) induced sediments from the Cretaceous of northeastern Mexico: Abstracts with Programs Geological Society of America, v. 34, p. 16.

Folk, R.L., 1980, Petrology of sedimentary rocks: Austin, TX, Hemphill Publ. Co., p. 184.

Folk, R.L., 1993, SEM imaging of bacteria and nannobacteria in carbonate sediments and rocks: Journal of Sedimentary Petrology, v. 63, p. 990-999.

Golubic, S. and Campbell, S.E., 1981, Biogenically formed aragonite concretions in marine Rivularia, in Monty, C., ed., Phanerozoic stromatolites; case histories: Berlin, Federal Republic of Germany (DEU), Springer-Verlag, p. 209-229.

Harries, P.J. and Kauffman, E.G., 1990, Patterns of survival and recovery following the Cenomanian-Turonian (Late Cretaceous) mass extinction in the Western Interior Basin, United States, in Kauffman, E.G. and Walliser, O.H., eds., Extinction events in earth history. Lecture Notes in Earth Sciences 30: Berlin, SpringerVerlag, p. 277-298.

Humphrey, W. E., Diaz, T., 2003, Jurassic and Cretaceous stratigraphy and tectonics of northeastern Mexico, Report of Investigation No. 267, Bureau of Economic Geology, The University of Texas at Austin, 152 p,+1 data CD. 
Humphrey, W.E., 1949, Geology of the Sierra de los Muertos area, Mexico (with descriptions of Aptian cephalopods from the La Pena Formation): Geological Society of America Bulletin, v. 60, p. 89-176.

Imlay, R.W., 1940, Neocomian faunas of northern Mexico: Geological Society of America Bulletin, v. 51, p. 117-190.

Imlay, R.W., 1938, Studies of the Mexican geosyncline: Geological Society of America Bulletin, v. 49, p. 1651-1694.

Imlay, R.W., 1937, Geology of the middle part of the Sierra de Parras, Coahuila, Mexico: Geological Society of America Bulletin, v. 48, p. 587-630.

Imlay, R.W., 1936, Evolution of the Coahuila Peninsula, Mexico; Part 4, Geology of the western part of the Sierra de Parras: Geological Society of America Bulletin, v. 47, p. 1091-1152.

Jenkyns, H.C., 1980, Cretaceous anoxic events; from continents to oceans: Journal of the Geological Society of London, v. 137, p. 171-188.

Jenkyns, H.C., Gale, A.S., and Corfield, R.M., 1994, Carbon- and oxygen-isotope stratigraphy of the English Chalk and Italian Scaglia and its palaeoclimatic significance: Geological Magazine, v. 131, p. 1-34.

Jones, T.S., 1938, Geology of Sierra de la Pena and paleontology of the Indidura Formation, Coahuila, Mexico: Geological Society of America Bulletin, v. 49, p. 69-149.

Kazmierczak, J. and Altermann, W., 2002, Neoarchean Biomineralization by Benthic Cyanobacteria: Science, v. 298, p. 2351.

Kazmierczak, J., Coleman, M.L., Gruszczynski, M., and Kempe, S., 1996, Cyanobacterial key to the genesis of micritic and peloidal limestones in ancient seas: Acta Palaeontologica Polonica, v. 41, p. 319-338.

Kazmierczak, J. and Kempe, S., 1992, Recent cyanobacterial counterparts of Paleozoic Wetheredella and related problematic fossils: Palaios, v. 7, p. 294-304.

Kazmierczak, J. and Krumbein, W.E., 1983, Identification of calcified coccoid cyanobacteria forming stromatoporoid stromatolites: Lethaia, v. 16, p. 207-213.

Kelly, W.A., 1936, Evolution of the Coahuila Peninsula, Mexico; Part 2, Geology of the mountains bordering the valleys of Acatita and Las Delicias: Geological Society of America Bulletin, v. 47, p. 1009-1038. 
Kerr, A.C., 1998, Oceanic plateau formation: a cause of mass extinction and black shale deposition around the Cenomanian-Turonian boundary?: Journal of the Geological Society, v. 155, p. 619-626.

Krom, M.D., Stanley, J.D., Cliff, R.A., and Woodward, J.C., 2002, Nile River sediment fluctuations over the past $7000 \mathrm{yr}$ and their key role in sapropel development: Geology, v. 30, p. 71-74.

Lamolda, M.A., 1978, Le passage Cenomanien-Turonien dans la coupe de Menoyo (Alaya, Alava). The Cenomanian-Turonian boundary in the Menoyo Section; Alaya, Alava: Cahiers de Micropaleontologie, p. 21-27.

Lamolda, M.A. and Mao, S., 1999, The Cenomanian-Turonian boundary event and dinocyst record at Ganuza (northern Spain): Palaeogeography, Palaeoclimatology, Palaeoecology, v. 150, p. 65-82.

Loope, D.B., Dingus, L., Swisher, C.C., III, and Minjin, C., 1998, Life and death in a late Cretaceous dune field, Nemegt Basin, Mongolia: Geology, v. 26, p. 27-30.

Norris, R.D, Kroon, D., Klaus, A., 2001, Introduction: Cretaceous-Paleogene climatic evolution of the western North Atlantic, results from ODP Leg 171B, Blake Nose. in: Kroon, D., Norris, R.D., Klaus, A., eds., Proceedings Ocean Drilling Project, Scientific Results, 171B: 1-11. Available from World Wide Web: http://wwwodp.tamu.edu/publications/171B SR/171bsr.htm.

North American Commission on Stratigraphic Nomenclature (NACSN), 1983, North American Stratigraphic Code: AAPG Bulletin, v. 67, p. 841-875.

O'brien, N.R., 1996, Shale lamination and sedimentary processes, in Kemp, A.E.S., ed., Palaeoclimatology and Palaeoceanography from Laminated Sediments: Geological Society of America, p. 23-36.

O'brien, N.R. and Slatt, R.M., 1990, Argillaceous rock atlas: New York, Springer-Verlag, p. -141 .

Robbins, L.L. and Blackwelder, P.L., 1992, Biochemical and ultrastructural evidence for the origin of whitings: A biologically induced calcium carbonate precipitation mechanism: Geology, v. 20, p. 464-468.

Robbins, L.L., Tao, Y., and Evans, C.A., 1997, Temporal and spatial distribution of whitings on Great Bahama Bank and a new lime mud budget: Geology, v. 25, p. 947-950.

Ross, M.A., Charleston, S., Smith, C.I., and Brown, J.B., 1981, Stratigraphy of the Tamaulipas Limestone, Lower Cretaceous, Mexico, in Charleston, S., Smith, C.I., and Brown, J.B., eds., Lower Cretaceous stratigraphy and structure, northern 
Mexico; field trip guidebook: Midland, TX, West Texas Geological Society, p. 43-57.

Schieber, J., 1986, The possible role of benthic microbial mats during the formation of carbonaceous shales in shallow mid-Proterozoic basins: Sedimentology, v. 33, p. $521-536$.

Schlanger, S.O. and Jenkyns, H.C., 1976, Cretaceous oceanic anoxic events; causes and consequences: Geologie en Mijnbouw, v. 55, p. 179-184.

Sen Gupta, R. and Naqvi, S.W.A., 1984, Chemical oceanography of the Indian Ocean, north of the equator: Deep-Sea Research, v. 31, p. 671-705.

Sinton, C.W. and Duncan, R.A., 1997, Potential links between ocean plateau volcanism and global ocean anoxia at the Cenomanian-Turonian boundary: Economic Geology, v. 92, p. 836-842.

Tatsumi, Y., Shinjoe, H., Ishizuka, H., Sager, W.W., and Klaus, A., 1998, Geochemical evidence for a mid-Cretaceous superplume: Geology, v. 26, p. 151-154.

Tribovillard, N., Trentesaux, A., Trichet, J., and Defarge, C., 2000, A Jurassic counterpart for modern kopara of the Pacific atolls:: lagoonal, organic matter-rich, laminated carbonate of Orbagnoux (Jura Mountains, France): Palaeogeography, Palaeoclimatology, Palaeoecology, v. 156, p. 277-288.

Tribovillard, N.P., 1998, Cyanobacterially generated peloids in laminated, organic-matter rich, limestones; an unobtrusive presence: Terra Nova.The European Journal of Geosciences, v. 10, p. 126-130.

Yates, K.K. and Robbins, L.L., 2001, Microbial lime-mud production and its relation to climate changes, in Gerhard, L.C., Harrison, W., and Hanson, B.M., eds., Geological perspectives of global climate change: Tulsa, American Association of Petroleum Geologists, p. 267-283.

Yates, K.K. and Robbins, L.L., 1998, Production of carbonate sediments by a unicellular green alga: American Mineralogist, v. 83, p. 1503-1509. 


\title{
CHAPTER VII
}

\section{Role of Cyanobacterial in Corg-rich deposits: an example from The Indidura Formation (Cenomanian-Turonian), northeastern Mexico}

\author{
Fabian Duque-Botero and Florentin J-M. R. Maurrasse \\ Submitted to Cretaceous Research, Dec 312005 \\ Accepted for publication May 2006
}

\subsection{Abstract}

We present evidence of accumulation of calcareous cyanobacterial "microspheroids" as predominant components of the Cenomanian-Turonian Indidura Formation of northeastern Mexico. The unit at Parras de la Fuente includes a sequence of limestones and marls with well-defined light-dark rhythms at the decimetric to millimetric scale, in which $\mathrm{CaCO}_{3}$ and total organic carbon vary between $43-78 \%$ and $0.3-3.6 \%$, respectively.

A distinctive feature of the section is the presence of abundant millimeter-scale microlaminae arranged in nearly even-parallel white and dark gray "varve like" dual lamination less than $3 \mathrm{~mm}$ thick, in which the darker units contain scattered planktonic foraminifera and radiolaria, whereas the lighter microlaminae are dominated by calcitic microspheroids $(20-40 \mu \mathrm{m})$. The white laminae are evidently the result of recurring cycles of calcareous cyanobacterial blooms, possibly associated with fluvial dilution of surface waters. 
The organic carbon-rich laminated marlstones and laminated biocalcilutites of the Indidura Formation document paleoceanographic conditions favorable to unusual cyanobacterial productivity cycles that were also characterized by strong dysoxic/anoxic bottom conditions.

\subsection{Introduction}

Recent studies of the Jurassic (Tribovillard, 1998) and Cretaceous (Kenig et al., 2001) systems from the Jura Mountains (France) and Cretaceous Western Interior Seaway (USA), and northeastern Mexico (Duque-Botero and Maurrasse, 2005) have shown that cyanobacteria can account for large proportions of marine organic matter. Arguments in favor of cyanobacteria as the main contributors to the Precambrian and Paleozoic rocks are also presented by Pratt (1984, 2001), Kazmierczak et al. (1996), Arp et al. (2001). Riding (2002) further argued that benthic cyanobacterial communities are the main constituents of calcium carbonate of Paleozoic and Precambrian carbonate sediments, while Ehrlich (1998) emphasized the idea that grazing pressure may explain the absence of cyanobacterial and bacterial deposits (micrite mud suppliers) in sedimentary sequences younger than Paleozoic, thereby causing a reduction in the preservation of calcium carbonate $\left(\mathrm{CaCO}_{3}\right)$ as a byproduct of photosynthesis. On the other hand, Arp et al. (2001) believed that the decrease in preservation of bacterial deposits during the Phanerozoic was directly controlled by changing concentrations of dissolved $\mathrm{CO}_{2}$ and $\mathrm{Ca}^{+}$ions in the ocean, and argued that precipitation is recorded only in restricted environments. 
In present-day marine environment, structures such as cyanobacterial S-layer are identified as nucleation sites for $\mathrm{CaCO}_{3}$ development (Schultze-Lam et al., 1992). Robbins and Blackwelder (1992) also demonstrated that the formation of whitings offshore Bahamas is related to cyanobacteria-induced precipitation of carbonate. Induced precipitation of calcite by aerobic and anaerobic bacteria, and cyanobacteria has been noted in both aquatic and terrestrial environments (Krumbein, 1974; Morita, 1980; Thompson and Ferris, 1990; Merz-Priess, 1992; Braissant et al., 2003).

Studies of Cretaceous sediments around the Tethys realm revealed that the mid Cretaceous was a time when unique paleoclimatic and paleoceanographic conditions (Schlanger and Jenkyns, 1976; Jenkyns, 1980; Arthur et al., 1990) favored unusual blooms of these prokaryotes. It is also known from the geological record that multiple and large igneous provinces (LIP's) formed from the outpouring of millions of cubic kilometers of basaltic magmas into the Cretaceous oceans (Larson, 1991; Sinton and Duncan, 1997; Kerr, 1998). Thus, emplacement of LIP's enhanced these conditions by their effects on both atmospheric and oceanic circulations due to increase in water volume by thermal expansion, and increased green house gases into the atmosphere (Brumsack, 2006). Indeed, the consequences of these major disturbances left their hallmarks in the geochemical, paleontological and sedimentological records in both deepocean and epicontinental-sea deposits of that time. Some of these major disruptions named “Oceanic Anoxic Events" (OAE's) are characterized by extensive preservation of organic carbon associated with widespread accumulation of "black shales" (Jenkyns, 1980). The Cenomanian/Turonian boundary interval was specifically influenced by such 
an event, termed the "Bonarelli Event" or OAE2 (Harries and Kauffman, 1990; Leckie et al. 2002).

Of special interest are the results of biomarker studies of Cretaceous OAE's that indicate a change in the type of organic matter produced and preserved during the anoxic intervals characterized by an increase or expansion of Bacteria-Archea-Cyanobacteria compounds (Kuypers et al., 2004; Dumitrescu and Brassell, 2005). We provide further sedimentological and petrographic evidence of cyanobacteria as the main constituents of the carbonate fraction in the Cenomanian/Turonian deposits of the Sierra Madre Oriental, Coahuila State, NE Mexico (Figure 7- 1). Sedimentary cycles of the Indidura Formation also allow a better understanding of the role that cyanobacteria played in the sedimentological processes that led to significant formation of Corg-rich deposits in that region.

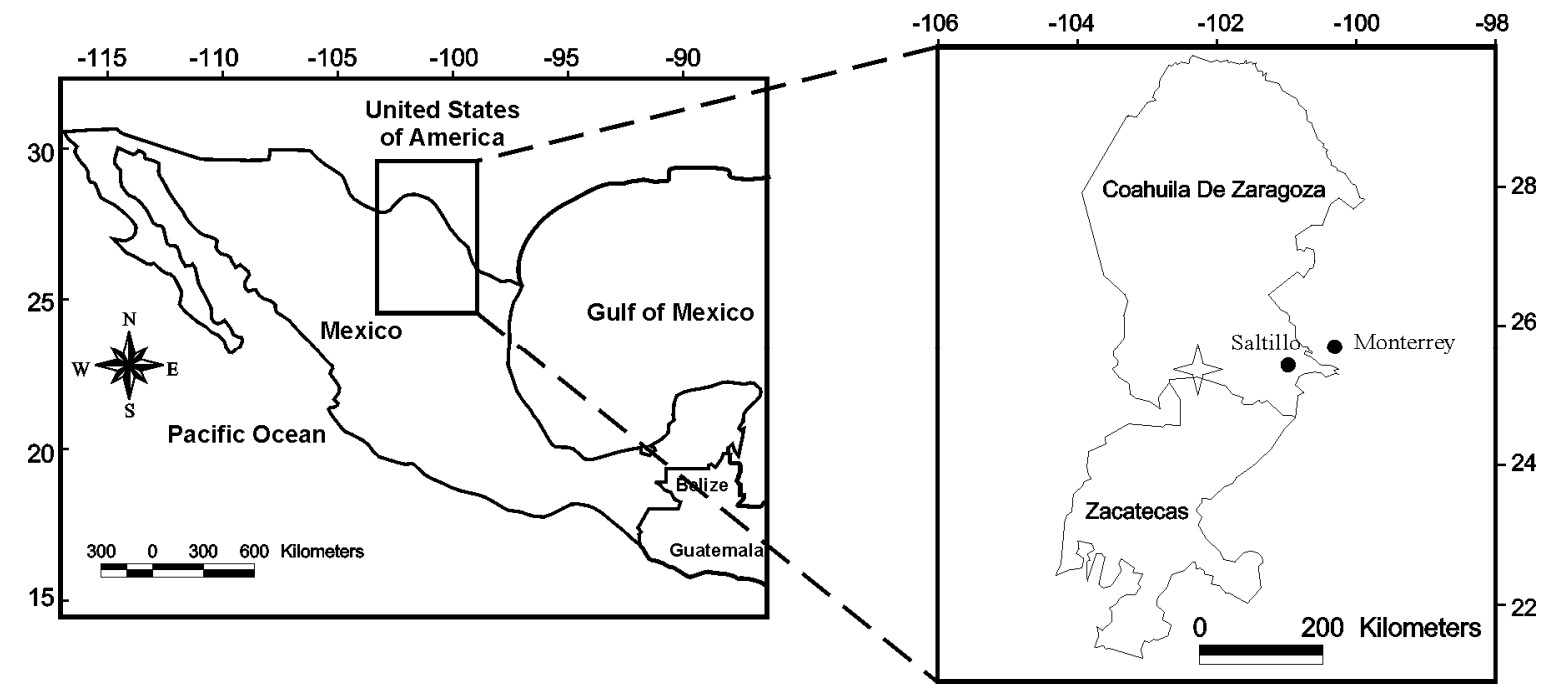

Figure 7- 1. Map showing location of the study area. 


\subsection{Stratigraphic Framework}

Cretaceous rocks of northeastern Mexico indicate that complex and lasting platform environments were established over the area since at least the Valanginian. As reviewed by Imlay (1936), who studied the stratigraphy of the Sierra Madre Oriental in the area of Saltillo-Torreon, the sedimentary sequence known as Indidura Formation was named and described by Kelly (1936) in the Las Delicias area of western Coahuila State (Figure 7- 1). Imlay (1936) expanded the name Indidura Formation (Figure 7-2) to rock sequences in the rest of the Sierra Madre Oriental, including the Parras area where the site studied is located. The Indidura Formation in the Parras area (Imlay, 1936) shows a transitional contact with the subjacent Cuesta del Cura Formation, which includes chert

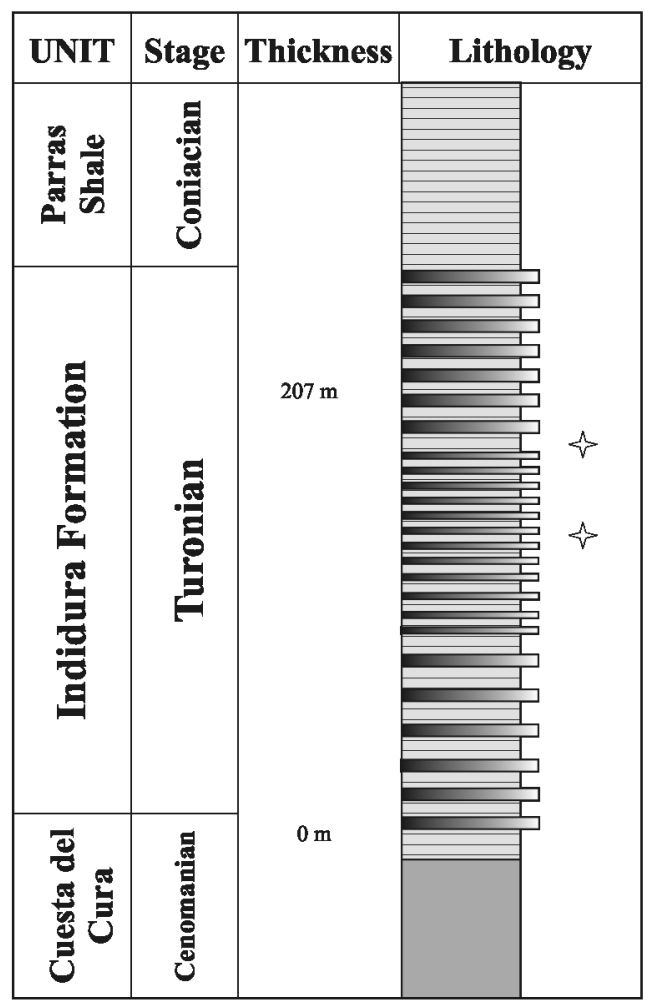

Figure 7- 2. Generalized stratigraphic section near Parras de la Fuente. The stars indicate the intervals where samples illustrated in the thin sections and SEM images come from. 
beds. It is also gradational with the superjacent Parras Shale (Figure 7-2) marked by the last appearance of limestone beds (Imlay, 1936).

Rocks referred to as the Indidura Formation in the study area consist of about 580 meters of distinctive interbeds of black and gray shale, up to $75 \mathrm{~cm}$ thick, with yellowish black limestone, up to $35 \mathrm{~cm}$ thick (Figure 7- 3). The lower part consists of 278 meters of laminated, gray, friable calcareous shales, interbedded with thick, dark-gray lenticular calcilutite. The middle part of the unit consists of 152 meters of finely laminated shales intercalated with sandy shales, with occasional secondary lenses of brown selenite up to $80 \mathrm{~cm}$ thick. The uppermost part consists of 150 meters of platy, gray calcareous shales and brown to light-gray shaly calcilutites with some intercalations of sandy shales that may also contain abundant selenite crystals. A Cenomanian-Turonian age has been assigned to the series based on ammonites (Jones, 1938) and planktonic foraminifers (Caron and Tardy, 1971).

\subsection{Samples and Laboratory Methods}

Samples were collected from sites at Sierra de Las Parras near the town of Parras de la Fuente, Coahuila (Figure 7- 1), GPS coordinates of $25^{\circ} 26^{\prime} 17.9^{\prime \prime} \mathrm{N} ; 102^{\circ} 12^{\prime} 54.7^{\prime \prime} \mathrm{W}$. We analyzed thin sections for standard petrographic studies, including microstructures and intrinsic sedimentological characteristics. Polished rock slabs, and thin sections were acid etched for imaging analyses with a SEM JSM-5900-LV to determine semiquantitative chemical composition. Organic Carbon/Carbonate contents were measured on fresh samples using a LECO CR-412 analyzer, and results are presented as carbon 


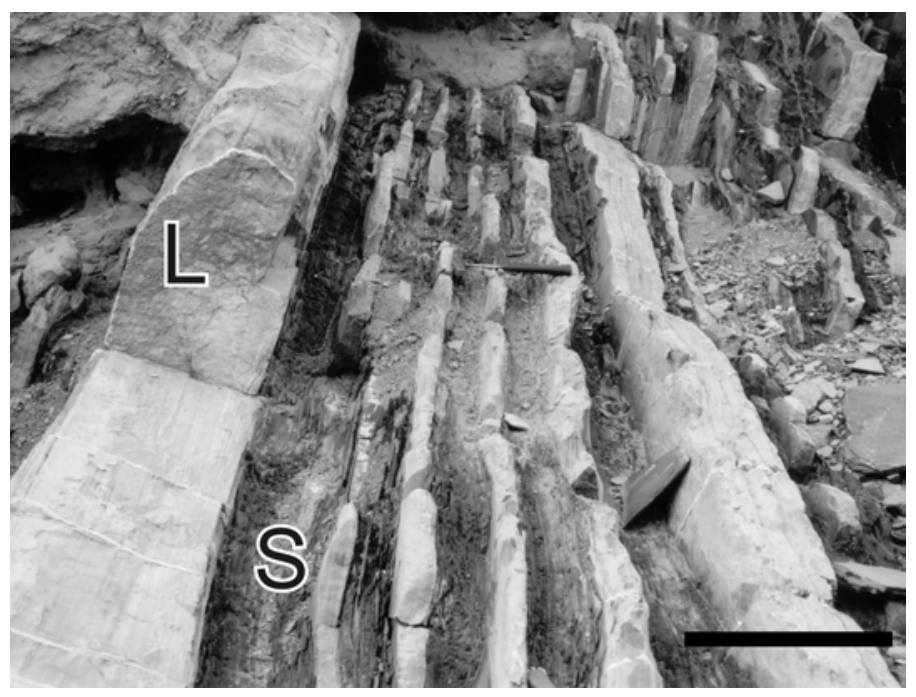

Figure 7- 3. Photograph showing typical intercalations of fine laminated calcilutites (L) and laminated marlstones $(\mathrm{S})$ from the middle part of the Indidura Formation, scale bar $=33 \mathrm{~cm}$.

percent C (\%) of dry bulk weight. Color codes follow the Geological Society of America Rock Color Chart.

\subsection{Localities and Petrographic Description}

At close examination of the field scale, the sequence consists of interbedded light olivegray $(5 \mathrm{Y} 6 / 1)$ and brownish-black to olive-black (5YR2/1 - 5Y2/1) marlstone (thin to very thick ca. 5 to $200 \mathrm{~cm}$ ), and shaly calcilutite (thin to very thick, ca. 8 to $100 \mathrm{~cm}$ ). Overall, the sequence is monotonous, containing no apparent macrofossils except for very rare Inoceramus labiatus? and ammonites. Shaly calcilutite beds make up more than $70 \%$ of the sequence, while the marlstone layers comprise only about $30 \%$. The most striking characteristic of these beds is the presence of persistent dark and light parallel laminae (1 to $2 \mathrm{~mm}$-thick). Microscopically, the laminae are formed of quasi-periodic occurrence of even parallel to wavy-parallel, dark and light sub-units forming couplets reminiscent 
of deposits described as "varves", although they have no petrogenetic relationship. These micro-laminae are more distinct in the highly laminated calcilutite beds than in the shaly marlstone. These differences can be related to the abundance of microspheroids as seen in thin sections (Figure 7-4). Light laminae are composed of (>95\%) single- or multiplecrystal calcite-filled "microspheroids" either as individual grains or in aggregates (calcite rhombohedra of 1-3 $\mu \mathrm{m}$ ) ranging in size between 5 and $100 \mu \mathrm{m}$, with a median size of 20 $\mu \mathrm{m}$ (Figure 7- 5). The groundmass, or the finer components, is less than $5 \%$ in the light laminae, whereas it is dominant in the dark ones where microspheroids become less abundant $(<10 \%)$. Dark laminae also include scattered planktonic foraminifera (mainly heterohelicids and double keeled forms), and scarce radiolarians (spumelarids); they include 30 to $50 \%$ undifferentiated clay size particles together with organic matter. On the whole, dispersive framboidal pyrite occurs as aggregates up to $5 \%$ of the bulk sediment, while diagenetic pyrite cubes are found in less than $2 \%$. The main conspicuous cement throughout is composed of microsparite, although cementation by clay minerals cannot be ruled out. The thin section analysis reveals that the laminae that are apparently continuous at the macroscopic scale are in fact discontinuous, because they occur as uneven discrete units with pinch and swell structures within a fine grained calcareous matrix, including clay size particles and organic matter (Figure 7- 4).

\subsection{SEM Analyses}

Scanning electron microscopy of samples from Parras de la Fuente further characterizes the microstructures observed in the petrographic analyses. Both shaly calcilutite and 

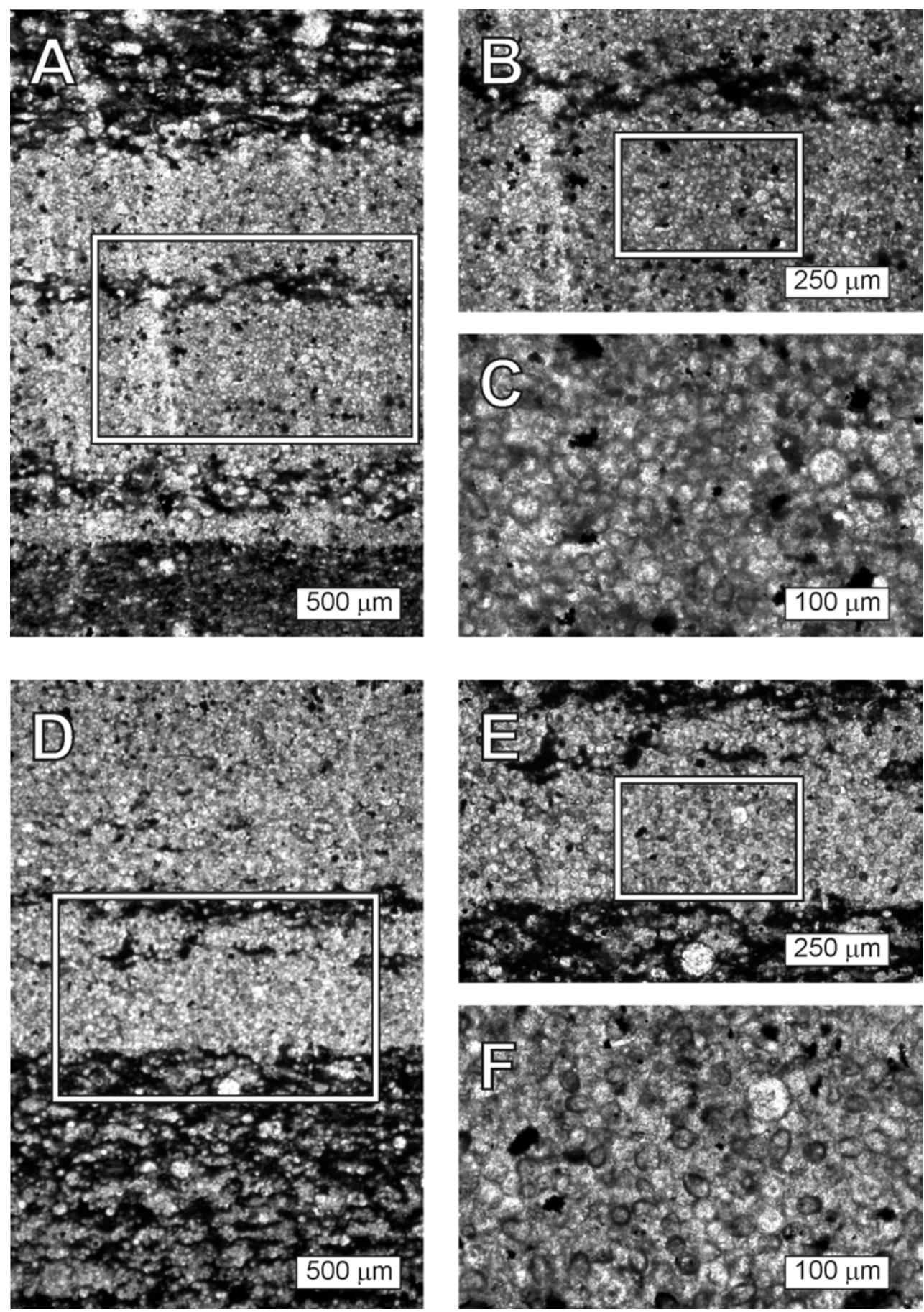

Figure 7- 4. Thin sections (A, D) of highly laminated calcilutite: conspicuous parallel laminations clearly form couplets that resemble "varves". These are even-parallel very thin laminae $<3 \mathrm{~mm}$, with pinch and swell structures. B and E correspond to magnifications of A, D respectively, microspheroids from a close framework with some pockets of organic matter in between. $\mathrm{C}$ and $\mathrm{F}$ are close-ups of $\mathrm{B}$ and $\mathrm{E}$ respectively, all microspheroids have a size between 20-40 $\mu \mathrm{m}$, but are consistently around $25 \mu \mathrm{m}$; note that in most microspheroids have a coating and shape that resemble Precambrian cyanophyte. All scales inside figures. 
marlstone layers are predominately composed of unequivocal microspheroids with consistent spherical, semi-spherical, and ovoid shapes, with a size range of ca. to 20$50 \mu \mathrm{m}$ (Figure 7- $5 \mathrm{~A}-\mathrm{L}$ ). These forms can occur as scattered spheroids, or in aggregates of microspheroid strings (Figure 7- $5 \mathrm{~L}$ ), and consistently exhibit a 3 to $5 \mu \mathrm{m}$-thick rim of microcrystalline calcite, comparable to a "test". However, the absence of a true organized microcrystalline structure even in the largest of the microspheroids rules out any relationship to the tests of other fossil groups (e.g., foraminifera, calcareous dinoflagelates, calcispheres, etc.). Furthermore, although some of the strings may resemble cross-section of the peripheral view of biserial planktonic foraminifera (e.g., heterohelicids), the wall structure observed in planktonic foraminifera always shows an orderly array of the crystals, while the "microspheroids" observed in SEM images show a random wall structure. In addition, the morphology presented by the orientation of the strings is consistently the same, it is highly unlikely that all biserial foraminifera found in multiple samples would uniformly orientate in such a way as to have only the peripheral view exhibited in both SEM and petrographic images. The microspheroid tests are composed of multiple crystals of calcite and are analogous to the internal structures revealed by strings of attached cells described by Golubic and Campbell (1981) and to cyanobacterial structures (Kazmierczak and Krumbein, 1983; Kazmierczak and Altermann, 2002; Braissant et al. 2003; Brehm et al. 2004). Some of the microspheroids (Figure 7- 5 A, B, D, F) show original micro-calcite crystals $(<2 \mu \mathrm{m})$, while others have been recrystallized (Figure 7- 5 C). Furthermore, EDS analysis of the microcrystalline rim shows an excess of carbon, which is attributed to the organic-rich extracellular polymeric secretion (EPS) rich membranes that act as a nucleation center for 

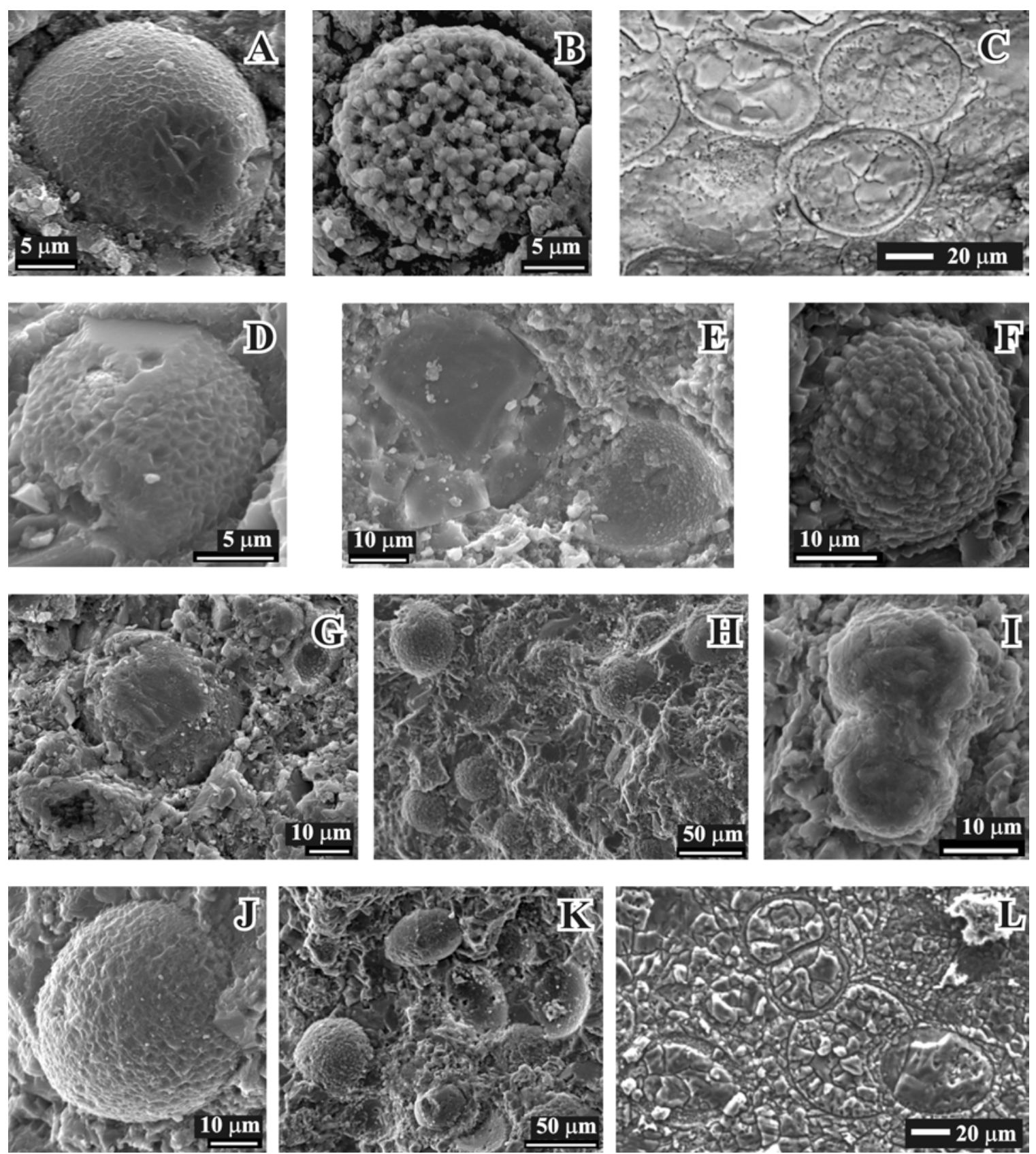

Figure 7- 5. SEM images showing different shapes of microspheroids : spherical (all images), semispherical and ovoid (I,K,L). Only those on (C and L) exhibit a 3 to $5 \mu \mathrm{m}$ rim of microcrystalline calcite that is reminiscent of a test. Microspheroids are made up of single crystal (A,D,E,I,L) or multiple crystals of sparry calcite (B,C,E,F,H,J,K,L); they are found isolated (A,B,D,E,F,G,H,J,K) or as aggregates that resemble strings of attached cells (C,E,H,I,L). All scales inside the figures. 
the precipitation of carbonate minerals. This feature is also observed under the petrographic microscope as a dark envelope covering the microspheroids (Figure 7-4). SEM semi-quantitative EDS analyses of samples from the Indidura Formation supports the petrographic observation indicating high clay content in sediments where the matrix is composed mainly of microcrystalline calcite and minor amounts of framboidal pyrite.

\subsection{TOC/TIC}

Results of the carbon/carbonate analyses are presented as percentages (\%) of total dry weight of organic and inorganic carbon in the bulk sample. As shown in Figure 7- 6, there is a strong contrast, and marked tendency between the different lithologies.

The samples yield high carbonate values that vary between $43 \%$ and $78.3 \%$, and TOC content that fluctuates between $0.3 \%$ and $3.6 \%$, most commonly higher than $1.6 \%$. The non-carbonate fraction varies between $4.7 \%$ and $34.6 \%$ (Figure 7- 6) TOC and $\mathrm{CaCO} 3$ values from the different facies show that these organic-rich sediments vary in both organic carbon and carbonate contents. Higher TOC (\%) and lower $\mathrm{CaCO} 3(\%)$ are consistently found in the less laminated shaly marlstone beds, while a reverse trend is observed for the highly laminated biocalcilutite layers where microspheroids are prevalent.

The maximum carbonate and organic carbon fractions show an increasing trend toward the middle of the section, which corresponds to the level where microspheroids increase to more than $50 \%$ of the laminated calcilutites, and about $20 \%$ of the marls. Subtraction 
of the carbonate content from the total carbon percentage shows that the laminated biocalcilutites have more organic matter than the marls, which suggests a dilution of the organic matter by the cyanobacterial microspheroids.

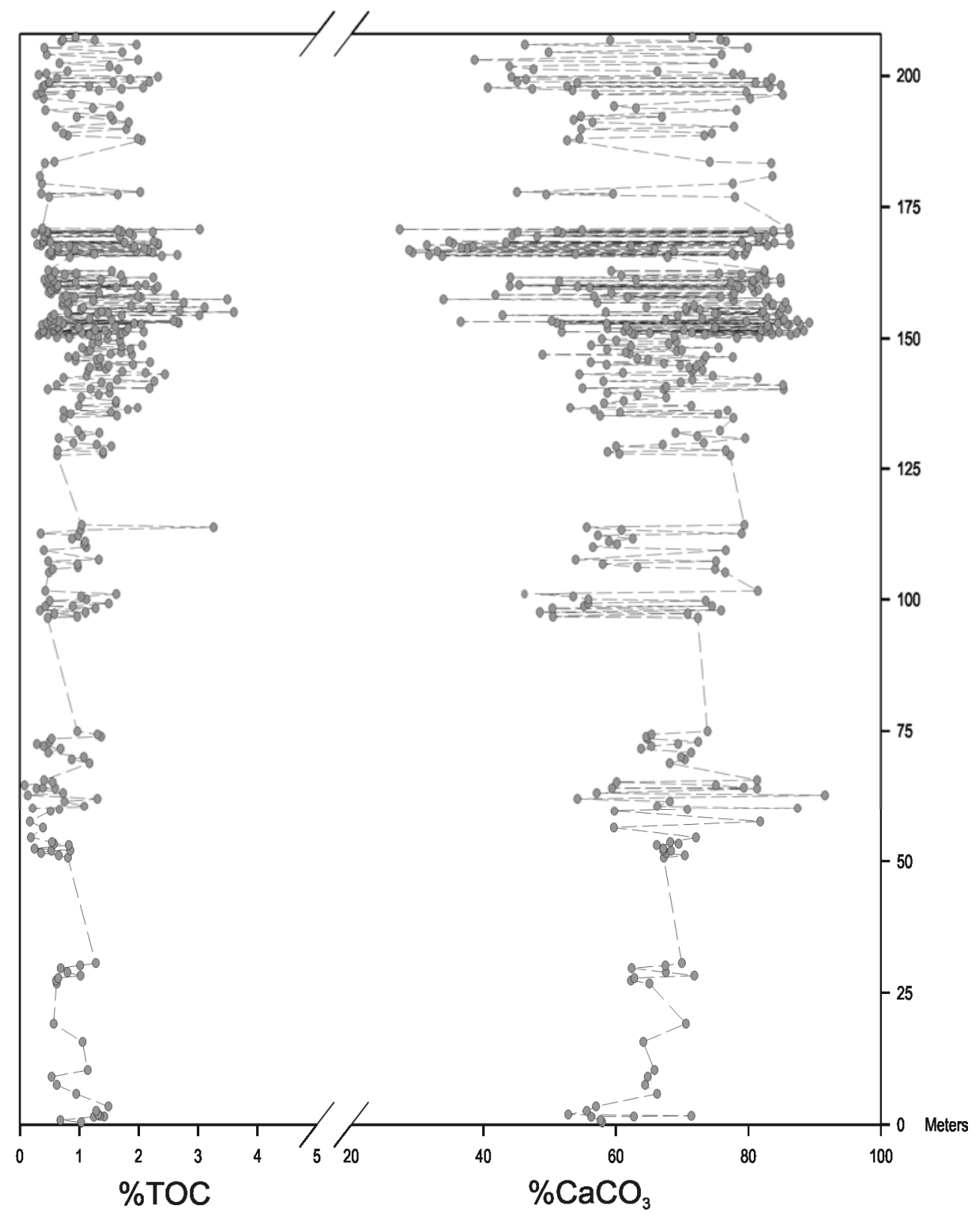

Figure 7- 6. TOC and Total Carbonate vs. stratigraphic distance. High values of TOC correlate with samples where "microspheroids" were found. In addition, these correspond to zones with low bioperturbation and laminated marls Fig. 8.3c and highly laminated calcilutites see Fig. 8.3b. 


\subsection{Discussion and Conclusions}

Sedimentary structures associated with microspheroids that dominate the Parras deposits (Figure 7- 3) assigned to the Indidura Formation are here identified as fossilized counterparts of present-day cyanobacterial and microbial communities (Tribovillard, 1998; Tribovillard et al., 2000). Indeed, structures associated with these types of "microspheroids" in fine-grained sediments have been previously shown by Kazmierczak and Kempe (1992), Kazmierczak et al. (1996), Tribovillard (1998), Kazmierczak and Altermann (2002), Tribovillard, et al. (2000), Giralt et al. (2001) and Braissant et al. (2003) to represent the product of bacterial/cyanobacterial-induced precipitates.

Similarly, the laminae in Figure 7- 4 represent deposits related to bacterial activities that formed mats like those described by Schieber (1986), and O’brien (1996) in Paleozoic shales and associated rocks. Alternation of laminated sediments described here is also comparable with the organic rich and microspheroid/mucilaginous sheath intercalations found in sediments of the black sea and other oxygen-depleted basins. In such environments the water/sediment interphase is depleted in oxygen due to oxidation of organic mater through the water column (Pilskan and Pike, 2001; Chang et al., 2003). By analogy, the light laminae ( $>95 \%$ of microspheroids) in our samples represent remnants of calcifying cyanobacteria blooms that dominated the Parras Basin environment under stressed conditions, like those described by Dumitrescu and Brassell (2005), and Kuypers et al. (2004). Excessive proliferation of the prokaryotes excluded other microplankton, hence the absence of planktonic foraminifera and radiolaria in the microspheroid-rich laminae (Figure 7-4). In contrast, the couplets of dark laminae imply periods of nonstressful conditions that allowed incursion of other microplankton groups and a reduction 
of calcifying cyanobacteria. Consistent absence of benthic fauna in either type of facies indicates perennial anoxic/dysoxic bottom conditions, whereas periodic disappearances of planktonic organisms (foraminifera, radiolaria) further indicate recurrent competitive exclusion in the upper part of the water column when bacterial explosive blooms dominated, much as observed in certain areas of the modern oceans like the Indian Ocean (Devassy et al., 1978; Sen Gupta and Naqvi, 1984), mid-Atlantic and Pacific Oceans (Capone et al., 1997. Recurrence of enhanced production of calcifying cyanobacteria that resulted in dual "varve-like" lamination is compatible with periodic changes in the surface water conditions, such as fresh water input by rivers due to, for instance, seasonal melting of snow, as proposed for coeval deposits of the Cretaceous Western Interior Seaway (Pratt, 1985; Floegel et al., 2005. As it is known, inputs of fresh waters in relatively closed basins can adversely affect productivity of stenohaline organisms, thus allowing cyanobacteria to dominate the environment due to the lack of overturning of subsurface waters. The black laminae represent normal conditions when regular productivity took place. Perhaps, equivalent analogs to such bacterial production are those shown by blooms of planktonic calcifying cyanobacteria (Robbins and Blackwelder, 1992; Robbins et al., 1997; Yates and Robbins 1998, 2001); bacterially induced dolomite in anoxic cultures (Warthmann et al., 2000), and non-calcifying cyanobacteria (Carpenter, 1983; Carpenter and Romans, 1976) reported as common seasonal occurrences in present oceans.

High TOC content observed in the deposits at Parras de La Fuente further indicates that depleted oxygen conditions remained prevalent in that area throughout the whole section, 
as corroborated by scarce inoceramids, the absence of other benthic organisms, and low level of bioturbation. Thus, anoxic to dysoxic bottom water prevailed in this part of the platform, while in other areas, at La Delicias for instance, bottom conditions remained well ventilated as shown by total obliteration of primary sedimentary structures and rich epifauna.

The cause of widespread anoxia is still uncertain, but Mid-Cretaceous enhanced hydrothermal activity (Larson, 1991; Caldeira and Rampino, 1991) may have been an important factor favorable to the development of $\mathrm{C}_{\text {org-rich }}$ deposits. Indeed, the geologic record indicates that it was a time of increased sea floor spreading, as well as emplacement of the latest stages of the large igneous provinces (LIP's): Ontong-Java and Caribbean plateaus (Sinton and Duncan, 1997; Kerr, 1998). Since hydrothermal activities increased iron flux in ocean waters, it will in turn tend to produce large-scale phytoplankton blooms in areas where Fe acted as the biolimiting nutrient. In such cases, increased supply of organic matter and decomposition through the water column would intensify oxygen consumption and reduce available $\mathrm{O}_{2}$, conditions that will be optimum for generation of black shales. However, under present oceanic conditions, it is observed that hydrothermally produced $\mathrm{Fe}^{2+}$ is readily precipitated as iron sulfides in black smokers (Jickells et al., 2005). Therefore, if iron from LIP's had a role in enhanced productivity, the mid-Cretaceous widespread anoxia must have delayed or prevented any precipitation of iron sulfides (e.g. pyrite) formed by hydrothermal activity. Although geochemical changes in the ocean waters may have contributed to the cyanobacterial blooms, the exact controlling mechanism of cyclical lamination and bedding observed in 
the Indidura Formation remains uncertain. Considering the paleogeography of the area, however, we invoke a situation analogous to those observed for the accumulation of sapropels in the Mediterranean Sea (Krom et al., 2002) and related to regional climatic influences. Further enhancement by iron-rich or iron-poor riverine waters, in combination with nitrogen limitation, would have created ideal conditions where periodic cyanobacterial blooms produced alternating levels of high concentrations of microspheroids and/or high organic productivity from non-calcifying bacteria. Furthermore, elevated mid-Cretaceous $p \mathrm{CO}_{2}$ from enhanced hydrothermal and volcanic activity helped to elevate Mesozoic global climate temperatures with maximum levels reached during the Turonian, and should have contributed to intensify continental runoff and chemical weathering (Bice and Norris, 2002), therefore, increasing nutrients fluxes to oceanic waters. Continuous overall high productivity also caused permanent conditions of low dissolved $\mathrm{O}_{2}$ in the lower part of the water column that allowed the preservation and accumulation of $\mathrm{C}_{\text {org-rich }}$ sediments throughout. The recurrent process of alternating dominance of different types of prokaryotes generated the varve-like laminae and bed couplets observed in the succession of the Indidura Formation at Parras. Thus, unusually high bacterial productivity throughout the accumulation of the Cenomanian/Turonian deposits at Parras indicates unique conditions of prolonged oxygen depletion in that area. The unusual depositional environment of the Parras basin, was further enhanced by worldwide relatively low-oxygen concentrations that existed in the "Mid" Cretaceous oceans. 


\subsection{Acknowledgments}

This work was partially funded by the Dissertation Year Fellowship of Florida International University, awarded to Fabian Duque-Botero; the Glenn A. Goodfriend Memorial funds, and other private funding sources. Many thanks to Mihaela Melinte for her assistance in nannoplankton biostratigraphy, Barbara Maloney at the Florida International University Center for Analytical Electron Microscopy (FCAEM) for her assistance with SEM images, and Diane Pirie for her graciousness and patience in keeping the CR-412 Carbon Analyzer in working condition. The manuscript benefited from the careful reviews of N. P. Tribovillard, and P. Meyers. We are grateful as well to Ignacio Chacon whose field assistance was invaluable. Special thanks to the ISC7 organizers Karl Föllmi and Thierry Adatte, and to the University of Neuchâtel who supported the symposium, and provided financial assistance to attend the conference in Neuchatel. This is contribution No. 05-04 of the sedimentology and stratigraphy group at FIU. 


\subsection{References}

Arp, G., Reimer, A., and Reitner, J., 2001, Photosynthesis-Induced Biofilm Calcification and Calcium Concentrations in Phanerozoic Oceans: Science, v. 292, p. 17011704.

Arthur, M.A., Jenkyns, H.C., Brumsack, H.J., and Schlanger, S.O., 1990, Stratigraphy, geochemistry, and paleo-oceanography of organic carbon-rich Cretaceous sequences, in Ginsburg, R.N. and Beaudoin, B., eds., Cretaceous resources, events and rhythms; background and plans for research: Dordrecht-Boston, D. Reidel Publishing Company, p. 75-119.

Bice, K.L. and Norris, R.D., 2002, Possible atmospheric CO2 extremes of the Middle Cretaceous (late Albian-Turonian): Paleoceanography, v. 17, (4), 1070, doi:10.1029/2002PA000778, 2002.

Braissant, O., Cailleau, G., Dupraz, C., and Verrecchia, E.P., 2003, Bacterially Induced Mineralization of Calcium Carbonate in Terrestrial Environments: The Role of Exopolysaccharides and Amino Acids: Journal of Sedimentary Research, v. 73, p. $485-490$.

Brehm, U., Palinska, K.A., and Krumbein, W.E., 2004, Laboratory cultures of calcifying biomicrospheres generate ooids - A contribution to the origin of oolites: Carnets de Géologie /Notebooks on Geology, v. Letter 2004/03 (CG2004_L03) http://paleopolis.rediris.es/cg/CG2004_L03/.

Brumsack, H.J., 2006, The trace metal content of recent organic carbon-rich sediments: Implications for Cretaceous black shale formation: Palaeogeography, Palaeoclimatology, Palaeoecology, v. 232, p. 344-361.

Caldeira, K. and Rampino, M.R., 1991, The Mid-Cretaceous superplume, carbon dioxide, and global warming: Geophysical Research Letters, p. 987-990.

Capone, D.G., Zehr, J.P., Paerl, H., Bergman, B., and Carpenter, E.J., 1997, Trichodesmium, a Globally Significant Marine Cyanobacterium: Science, v. 276, p. 1221.

Caron, M. and Tardy, M., 1971, Precisions sur l'age cretace superieur de la formation Indidura des abords de la Laguna de Mayran, Coahuila, Mexique. The upper Cretaceous age of Indidura Formation of the Laguna de Mayran shore, Coahuila, Mexico: Bulletin de la Societe Geologique de France, v. 7, p. 361-363.

Carpenter, E.J., 1983, Physiology and ecology of marine planktonick Oscillatoria (Trichodesmium): Marine Biology Letters, v. 4, p. 69-85. 
Carpenter, E.J. and Romans, K., 1976, Marine Oscillatoria (Trichodesmium): explanation for aerobic nitrogen fixation: Science, v. 191, p. 1278-1280.

Chang, A., Patterson, T., and McNeely, R., 2003, Seasonal Sediment and Diatom Record from Late Holocene Laminated Sediments, Effingham Inlet, British Columbia, Canada: Palaios, v. 18, p. 477-494.

Devassy, V.P., Bahattathiri, P.M.A., and Qasim, S.Z., 1978, Trichodesmium phenomenon: Indian Journal of Marine Sciences, v. 7, p. 168-186.

Dumitrescu, M. and Brassell, S.C., 2005, Biogeochemical assessment of sources of organic matter and paleoproductivity during the early Aptian Oceanic Anoxic Event at Shatsky Rise, ODP Leg 198: Organic Geochemistry, v. 36, p. 1002-1022.

Duque-Botero, F. and Maurrasse, F.J.-M.R., 2005, Cyanobacterial productivity, variations in the organic matter and facies of the Indidura Formation (Cenomanian-Turonian), Northeastern Mexico: Journal of Iberian Geology, v. 31, p. 87-100.

Ehrlich, H.L., 1998, Geomicrobiology: its significance for geology: Earth-Science Reviews, v. 45, p. 45-60.

Floegel, S., Hay, W.W., DeConto, R.M., and Balukhovsky, A.N., 2005, Formation of sedimentary bedding couplets in the Western Interior Seaway of North America-implications from climate system modeling: Palaeogeography, Palaeoclimatology, Palaeoecology, v. 218, p. 125-143.

Giralt, S., Julia, R., and Klerkx, J., 2001, Microbial Biscuits of Vaterite in Lake Issyk-Kul (Republic of Kyrgyzstan): Journal of Sedimentary Research, v. 71, p. 430-435.

Golubic, S. and Campbell, S.E., 1981, Biogenically formed aragonite concretions in marine Rivularia, in Monty, C., ed., Phanerozoic stromatolites; case histories: Berlin, Federal Republic of Germany (DEU), Springer-Verlag, p. 209-229.

Harries, P.J. and Kauffman, E.G., 1990, Patterns of survival and recovery following the Cenomanian-Turonian (Late Cretaceous) mass extinction in the Western Interior Basin, United States, in Kauffman, E.G. and Walliser, O.H., eds., Extinction events in earth history. Lecture Notes in Earth Sciences 30: Berlin, SpringerVerlag, p. 277-298.

Imlay, R.W., 1936, Evolution of the Coahuila Peninsula, Mexico; Part 4, Geology of the western part of the Sierra de Parras: Geological Society of America Bulletin, v. 47, p. 1091-1152.

Jenkyns, H.C., 1980, Cretaceous anoxic events; from continents to oceans: Journal of the Geological Society of London, v. 137, p. 171-188. 
Jickells, T.D., An, Z.S., Andersen, K.K., Baker, A.R., Bergametti, G., Brooks, N., Cao, J.J., Boyd, P.W., Duce, R.A., Hunter, K.A., Kawahata, H., Kubilay, N., laRoche, J., Liss, P.S., Mahowald, N., Prospero, J.M., Ridgwell, A.J., Tegen, I., and Torres, R., 2005, Global Iron Connections Between Desert Dust, Ocean Biogeochemistry, and Climate: Science, v. 308, p. 67-71.

Jones, T.S., 1938, Geology of Sierra de la Pena and paleontology of the Indidura Formation, Coahuila, Mexico: Geological Society of America Bulletin, v. 49, p. 69-149.

Kazmierczak, J. and Altermann, W., 2002, Neoarchean Biomineralization by Benthic Cyanobacteria: Science, v. 298, p. 2351.

Kazmierczak, J., Coleman, M.L., Gruszczynski, M., and Kempe, S., 1996, Cyanobacterial key to the genesis of micritic and peloidal limestones in ancient seas: Acta Palaeontologica Polonica, v. 41, p. 319-338.

Kazmierczak, J. and Kempe, S., 1992, Recent cyanobacterial counterparts of Paleozoic Wetheredella and related problematic fossils: Palaios, v. 7, p. 294-304.

Kazmierczak, J. and Krumbein, W.E., 1983, Identification of calcified coccoid cyanobacteria forming stromatoporoid stromatolites: Lethaia, v. 16, p. 207-213.

Kelly, W.A., 1936, Evolution of the Coahuila Peninsula, Mexico; Part 2, Geology of the mountains bordering the valleys of Acatita and Las Delicias: Geological Society of America Bulletin, v. 47, p. 1009-1038.

Kenig, F., Simons, D.J., and Anderson, K.B., 2001, Distribution and origin of ethylbranched alkanes in a Cenomanian transgressive shale of the Western Interior Seaway (USA): Organic Geochemistry, v. 32, p. 949-954.

Kerr, A.C., 1998, Oceanic plateau formation: a cause of mass extinction and black shale deposition around the Cenomanian-Turonian boundary?: Journal of the Geological Society, v. 155, p. 619-626.

Krom, M.D., Stanley, J.D., Cliff, R.A., and Woodward, J.C., 2002, Nile River sediment fluctuations over the past $7000 \mathrm{yr}$ and their key role in sapropel development: Geology, v. 30, p. 71-74.

Krumbein, W.E., 1974, On the Precipitation of Aragonite on the Surface of Marine Bacteria: Naturwissenschaften, v. 61, p. 167, 1974.

Kuypers, M.M.M., van Breugel, Y., Schouten, S., Erba, E., and Sinninghe Damste, J.S., 2004, N (sub 2) -fixing cyanobacteria supplied nutrient $\mathrm{N}$ for Cretaceous oceanic anoxic events: Geology, v. 32, p. 853-856. 
Larson, R.L., 1991, Geological consequences of superplumes: Geology, v. 19, p. 963966.

Leckie, R.M., Bralower, T.J., and Cashman, R., 2002, Oceanic anoxic events and plankton evolution: Biotic response to tectonic forcing during the midCretaceous: Paleoceanography, v. 17, p. 29.

Merz-Preiss, M., 1992, The biology of carbonate precipitation by cyanobacteria: Facies, v. 26, p. 81-101.

Morita, R.Y., 1980, Calcite precipitation by marine bacteria: Geomicrobiology Journal, v. 2, p. 63-82.

O'brien, N.R., 1996, Shale lamination and sedimentary processes, in Kemp, A.E.S., ed., Palaeoclimatology and Palaeoceanography from Laminated Sediments: Geological Society of America, p. 23-36.

Pilskaln, C.H. and Pike, J., 2001, Formation of Holocene sedimentary laminae in the Black Sea and the role of the benthic flocculent layer: Paleoceanography, v. 16, p. $1-19$.

Pratt, B.R., 2001, Calcification of cyanobacterial filaments: Girvanella and the origin of lower Paleozoic lime mud: Geology, v. 29, p. 763-766.

Pratt, B.R., 1984, Epiphyton and Renalcis; diagenetic microfossils from calcification of coccoid blue-green algae: Journal of Sedimentary Research, v. 54, p. 948-971.

Pratt, L.M., 1985, Isotopic studies of organic matter and carbonate in rocks of the Greenhorn marine cycle, in Pratt, L.M., Kauffman, E.G., and Zelt, F.B., eds., Fine-grained Deposits and Biofacies of the Cretaceus Western Interior Seaway. Evidence of Cyclic Sedimentation Processes, Field Trip Guidebook, vol. 4: Society of Economic Paleontologists and Mineralogists, p. 38-48.

Riding, R., 2002, Biofilm architecture of Phanerozoic cryptic carbonate marine veneers: Geology, v. 30, p. 31-34.

Robbins, L.L. and Blackwelder, P.L., 1992, Biochemical and ultrastructural evidence for the origin of whitings: A biologically induced calcium carbonate precipitation mechanism: Geology, v. 20, p. 464-468.

Robbins, L.L., Tao, Y., and Evans, C.A., 1997, Temporal and spatial distribution of whitings on Great Bahama Bank and a new lime mud budget: Geology, v. 25, p. 947-950.

Schieber, J., 1986, The possible role of benthic microbial mats during the formation of carbonaceous shales in shallow mid-Proterozoic basins: Sedimentology, v. 33, p. 521-536. 
Schlanger, S.O. and Jenkyns, H.C., 1976, Cretaceous oceanic anoxic events; causes and consequences: Geologie en Mijnbouw, v. 55, p. 179-184.

Schultze-Lam, S., Harauz, G., and Beveridge, T.J., 1992, Participation of a cyanobacterial S-layer in fine grained mineral formation: Journal of Bacteriology, v. 174, p. 7971-7981.

Sen Gupta, R. and Naqvi, S.W.A., 1984, Chemical oceanography of the Indian Ocean, north of the equator: Deep-Sea Research, v. 31, p. 671-705.

Sinton, C.W. and Duncan, R.A., 1997, Potential links between ocean plateau volcanism and global ocean anoxia at the Cenomanian-Turonian boundary: Economic Geology, v. 92, p. 836-842.

Thompson, J.B., Ferris, F.G., and Smith, D.A., 1990, Geomicrobiology and sedimentology of the mixolimnion and chemocline in Fayetteville Green Lake, New York: Palaios, v. 5, p. 52-75.

Tribovillard, N., Trentesaux, A., Trichet, J., and Defarge, C., 2000, A Jurassic counterpart for modern kopara of the Pacific atolls: lagoonal, organic matter-rich, laminated carbonate of Orbagnoux (Jura Mountains, France): Palaeogeography, Palaeoclimatology, Palaeoecology, v. 156, p. 277-288.

Tribovillard, N.P., 1998, Cyanobacterially generated peloids in laminated, organic-matter rich, limestones; an unobtrusive presence: Terra Nova.The European Journal of Geosciences, v. 10, p. 126-130.

Warthmann, R., Lith, Y.v., Vasconcelos, C., McKenzie, J.A., and Karpoff, A.M., 2000, Bacterially induced dolomite precipitation in anoxic culture experiments: Geology, v. 28, p. 1091-1094.

Yates, K.K. and Robbins, L.L., 2001, Microbial lime-mud production and its relation to climate changes, in Gerhard, L.C., Harrison, W., and Hanson, B.M., eds., Geological perspectives of global climate change: Tulsa, American Association of Petroleum Geologists, p. 267-283.

Yates, K.K. and Robbins, L.L., 1998, Production of carbonate sediments by a unicellular green alga: American Mineralogist, v. 83, p. 1503-1509. 


\section{CHAPTER VIII}

\section{Microspheroids Accumulation and Geochemistry of an Anoxic Basin of the Cenomanian/Turonian: The Record of the Indidura Formation, NE}

Mexico

Fabian Duque-Botero, Florentin J-M.R. Maurrasse, Rosemary Hickey-Vargas, Mihaela Carmen Melinte, Rudolf Jaffe and Jose Guadalupe Lopez-Oliva Submitted to SEPM Special Pub, Geol. Probl. Solv. With Microfossils, March 72006

\subsection{Abstract}

Cyanobacteria/bacteria are a major part of the biomass, although their recognition as significant constituents of the sedimentary record has been mainly overlooked in rocks other than Precambrian and Paleozoic stromatolites. Their extremely small size has been one of the major obstacles in the recognition of such constituents that can be properly observed only at high resolution SEM imaging. Here we present evidence of accumulation of cyanobacterial "microspheroids" as predominant components of sediments of the Cenomanian/Turonian deposits in the "Sierra de Parras", northeastern Mexico, during an interval of predominately dysoxic to anoxic conditions.

The stratigraphic section includes a sequence of limestones and marls with well-defined rhythms at the decimeter to millimeter scales. This facies shows internal structures that are arranged in nearly even-parallel "varve-like" dual lamination less than $3 \mathrm{~mm}$ thick. 
Few scattered planktonic foraminifera and radiolaria occur in the dark laminae, while the light laminae are composed almost entirely of microspheroids. Total carbonate $\left(\mathrm{CaCO}_{3}\right)$ content varies from $43.0 \%$ to $78.3 \%$, and TOC is relatively high, between $0.3 \%$ and $3.6 \%$, consistently higher than $1.6 \%$, suggesting a favorable environment for preservation of organic matter. Inorganic geochemical proxies for paleo-oxygen levels e.g. Mo, V, Cr, further concur that the sequence at Parras accumulated in a dysoxic to anoxic environment in which microbial communities were predominant, as revealed by petrographic and SEM analyses.

Microfacies reveal that compositional differences in the laminae are associated with varying abundance of cyanobacterial "microspheroids". The distinctive laminae are the result of recurring cycles of calcareous cyanobacteria blooms, which remained dominant throughout the sedimentary sequence.

Corg-rich black shales and limestones of the Parras region further document unique paleoceanographic situations during the early Late Cretaceous, when strong intermittent dysoxic/anoxic bottom conditions developed, and were associated with rhythmical production of cyanobacteria.

\subsection{Introduction}

Precambrian and Paleozoic rocks contain a rich spectrum of cyanobacterial and microbial components interpreted to be the main sediment contributors in the shallow water environments (Pratt, 1984, 2001; Kazmierczak et al., 1996; Arp et al., 2001). Riding 
(2002) further argued that cyanobacterial communities are the main carbonate constituents of Precambrian and Paleozoic sediments. Ehrlich (1998) emphasized that grazing pressure may explain the absence of cyanobacterial and bacterial deposits (micrite mud suppliers) in calcareous sedimentary sequences younger than Paleozoic, thereby causing a reduction in the preservation of calcium carbonate $\left(\mathrm{CaCO}_{3}\right)$ as a byproduct of photosynthesis. On the other hand, Arp et al. (2001) pointed out that the decrease in preservation of bacterial deposits during the Phanerozoic was directly controlled by changing concentrations of dissolved $\mathrm{CO}_{2}$ and $\mathrm{Ca}^{+}$ions in the ocean, and argued that precipitation is recorded only in restricted environments. Recent studies of Jurassic (Tribovillard, 1998) and Cretaceous (Kenig et al., 2001) systems from the Jura Mountains (France) and the Cretaceous Western Interior Seaway (USA), and northeastern Mexico (Duque-Botero and Maurrasse, 2005) have shown that cyanobacteria can account for large proportions of marine organic matter and carbonate mud.

Induced precipitation of calcite by aerobic and anaerobic bacteria, and cyanobacteria has been observed for both aquatic and terrestrial environments (Krumbein, 1974; Morita, 1980; Thompson et al., 1990; Merz-Priess, 1992; Braissant et al., 2003), and biological structures such as the cyanobacterial S-layer are identified in present day environments as nucleation sites for $\mathrm{CaCO}_{3}$ development (Schultze-Lam et al., 1992). Robbins and Blackwelder (1992) also demonstrated that the formation of whitings offshore Bahamas is related to cyanobacteria-induced carbonate precipitation. 
Studies of mid-Cretaceous rocks have shown that bacteria, archaea and cyanobacteria were major contributors of the organic detritus in different marine environments (Kenig et al., 2001; Kuypers et al. 2001, 2002; Dumitrescu and Brassell, 2005). Their importance became particularly evident during Oceanic Anoxic Events (OAE’s), which are characterized by extensive preservation of organic carbon associated with worldwide accumulation of organic rich mudstones or "black shales" (Jenkyns, 1980). The Cenomanian/Turonian boundary event, also known as the "Livello Bonarelli Event" or Oceanic Anoxic Event 2 (OAE2), is of special interest as it coincides with intense warm periods (Leckie et al., 2002), and includes major extinctions of marine fossils e.g. planktonic foraminifera (Leckie et al., 2002), rudists and inoceramids (Harries and Kauffman, 1990). Recent studies (Lamolda et al, 1997; Premoli-Silva et al., 1999; Erba, 2004) indicate that, within the Cenomanian/Turonian boundary interval, a major and floral turnover, related to the new paleophysiographic conditions, took place. Deposits associated with OAE2 show considerable increase in organic carbon that has been related to the expansion of certain groups like bacteria, archaea, cyanobacteria, which must have played a dominant role as primary producers (Kuypers et al., 2004; Dumitrescu and Brassell, 2005).

Here, we provide a multi-proxy approach to further demonstrate that cyanobacteria remained as main constituents of the carbonate fraction in the Cenomanian/Turonian deposits of the Sierra Madre Oriental, Coahuila State, NE Mexico (Figure 8- 1). 


\subsection{Stratigraphic Characteristics and Age of the Indidura Formation}

The Indidura Formation, as described by Kelly (1936), accumulated on the northern part of the Mesozoic Mexican carbonate platform during the maximum global sea level stand of the Cenomanian/Turonian (Hancock, 1993; Gale et al., 2002). The Formation crops out in the Sierra Madre Oriental, in between the cities of Monterrey and Torreon, and the area of interest for this work covers outcrops close to the town of Parras de la Fuente, Coahuila, Mexico (Figure 8- 1). The youngest Cretaceous unit in the area is the Parras shale (Imlay, 1936), which is composed of black calcareous shales with interbedded dark gray siltstones, the lower boundary of this unit is defined by the last appearance of a limestone layer of the Indidura Formation. Figure 8- 2 shows a schematic section for the middle Cretaceous.

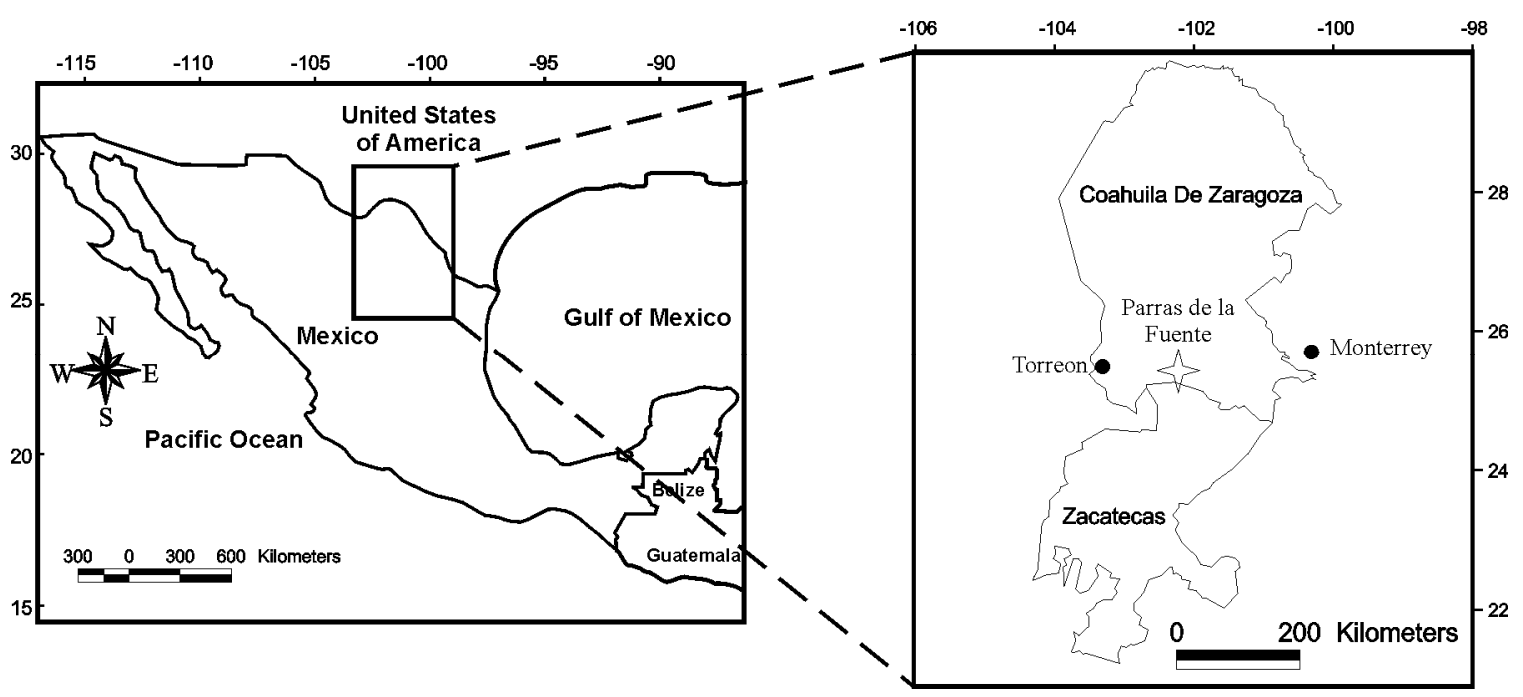

Figure 8- 1. Map showing location of the study area.

At Parras de la Fuente the Indidura Formation consists of a monotonous sequence of over 200 meters of prominent interbeds of light olive gray (5Y6/1) and brownish black to olive black (5YR2/1 - 5Y2/1) marls of 5 to $200 \mathrm{~cm}$ thick, and clayey calcilutites of 8 to $100 \mathrm{~cm}$ 


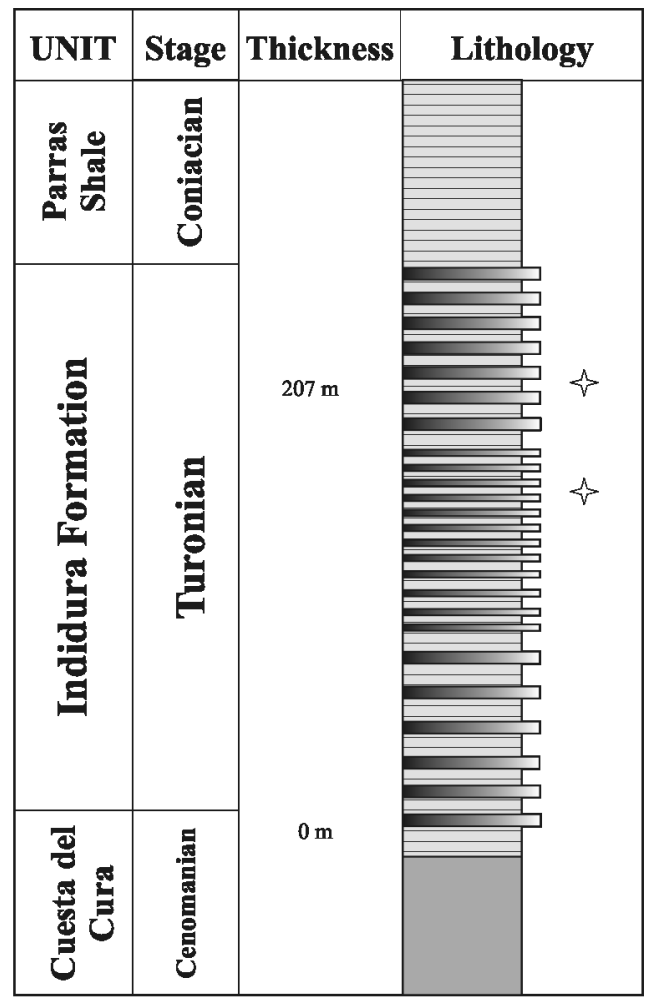

Figure 8- 2. Schematic stratigraphic position of the Indidura Formation near Parras de la Fuente. The stars indicate the intervals of samples illustrated in the thin sections and SEM images.

thick (Duque-Botero and Maurrasse, 2005). The bed sets form remarkable intercalations in a cyclical arrangement that give the Indidura Formation (Figure 8- 3 A) a very characteristic feature at the field scale that readily differentiates it from infrajacent and superjacent rocks. Closer examination reveals persistent parallel laminations that are 1 to $2 \mathrm{~mm}$ in thickness, which at the outcrop level appeared as a banding (Figure 8- 3 B,C). Macrofossils are very rare and consist of occasional inoceramids and ammonites (DuqueBotero and Maurrasse, 2005).

Previous studies (Imlay, 1936; Jones, 1938; Caron and Tardy, 1971) dated the Indidura Formation as Cenomanian to Coniacian age, based mainly on inoceramids and scarce 

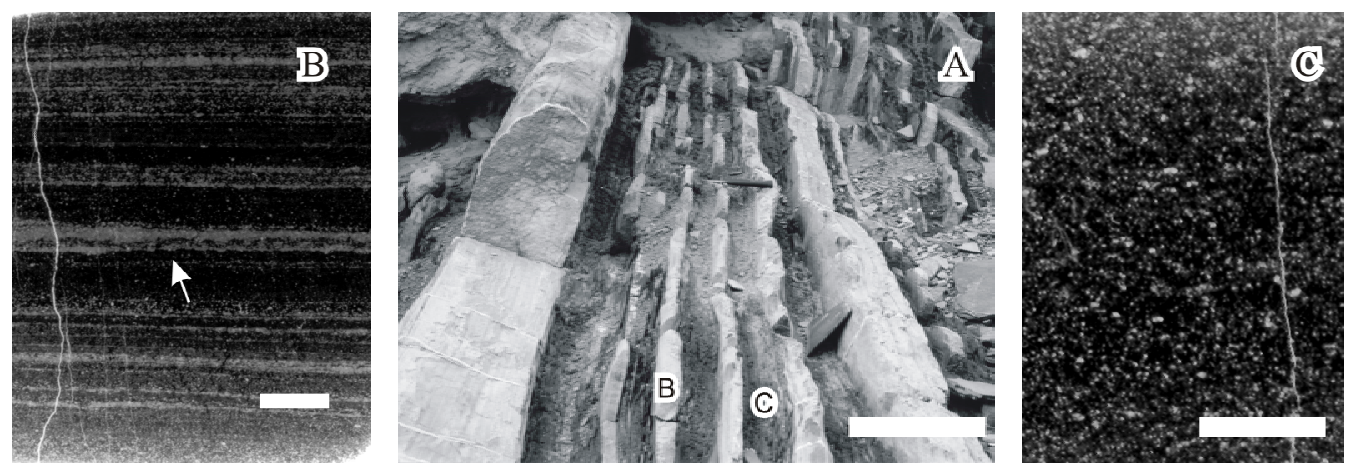

Figure 8- 3. A) Photograph of the Indidura Formation at Parras de la Fuente area showing typical intercalation of highly consolidated limestones and partly indurated marls, scale bar $33 \mathrm{~cm}$. B) Thin section of highly laminated calcilutite: conspicuous parallel laminae clearly form couplets that resemble "varves". These are even-parallel very thin laminae $<3 \mathrm{~mm}$, with pinch and swell structures (arrows), scale bar $0.5 \mathrm{~cm}$. C) Thin section from marl, scale bar $0.5 \mathrm{~cm}$.

planktonic foraminifera. Our nannofossil analyses indicate that the first occurrence (FO) of Quadrum gartneri Prins and Perch-Nielsen in Manivit et al., 1977 (= the base of the CC11 Calcareous Nannoplankton Zone of Sissingh, 1977) is placed within the lower part of the section. The nannofossils Lucianorhabdus maleformis Reinhardt, 1966 and Lithastrinus septenarius Forchheimer 1972, which indicate the CC12 and respectively CC13 calcareous nannoplankton zones of Sissingh (1977), successively first occur towards the upper part of the studied sequence.

Notably, the FO of Quadrum gartneri is a nannofloral event, which globally approximates the Cenomanian/Turonian boundary, as identified in many regions ( $\mathrm{N}$ Spain -Lamolda et al., 1997; Eastbourne, UK - Paul et al., 1999; Pueblo, Colorado, USA - Tsikos et al., 2004) within the earliest Turonian, at the top of OAE2. In the Gubbio section (Italy) the FO of Quadrum gartneri is placed also towards the top of OAE2, but within the latest Cenomanian (Premoli Silva et al., 1999; Tsikos et al., 2004). Concerning 
the FO of the nannofossil Lucianorhabdus maleformis, this is an Early Turonian event, while the FO and Lithastrinus septenarius took place within the Middle Turonian (Burnett, 1999).

Based on these microfossil data, we can more accurately constrain the Indidura Formation cropping out in the Parras section between the Cenomanian/Turonian boundary interval (CC11 Calcareous Nannoplankton Zone) and the Middle Turonian (CC13 Calcareous Nannoplankton Zone).

\subsection{Methodology}

Samples were collected from Sierra de Las Parras near the town of Parras de la Fuente, Coahuila (Figure 8- 1), GPS coordinates of $25^{\circ} 26^{\prime} 17.9^{\prime \prime} \mathrm{N} ; 102^{\circ} 12^{\prime} 54.7^{\prime \prime} \mathrm{W}$. We analyzed thin sections for standard petrographic studies, including microstructures and intrinsic sedimentological characteristics. Polished rock slabs, and thin sections were acid etched for imaging analyses and for semi-quantitative chemical composition with a SEM JSM-5900-LV. Color codes follow the Geological Society of America Rock Color Chart (Goddard et al., 1948).

Samples for geochemical analyses were selected throughout the section. They were powdered and homogenized with a micromill and subsequently treated for different geochemical analyses. Carbon/Carbonate contents were measured for all samples on a LECO CR-412 analyzer, with an accuracy of $\pm 1 \%$, and results are presented as carbon percent C (\%) of dry bulk weight of the carbon present determined by infrared detection. 
Samples analyzed for major and trace elements were treated by the EPA 3050b (USEPA, 1996) partial digestion method. It involves 1 gram of sample, which is acid attacked in 10 $\mathrm{ml}$ of $1: 1 \mathrm{HNO}_{3}$ at $95^{\circ} \mathrm{C}$ for 10 minutes, with addition of $5 \mathrm{ml}$ of $\mathrm{HNO}_{3}$ to dissolve and oxidize acid soluble minerals. After evaporation and complete desiccation, $2 \mathrm{ml}$ of water and $3 \mathrm{ml}$ of $\mathrm{H}_{2} \mathrm{O}_{2}$ were added, with continuous addition of $1 \mathrm{ml}$ of $\mathrm{H}_{2} \mathrm{O}_{2}$ to complete oxidation of organometallic compounds. The residue was heated for 2 hours, and then 10 $\mathrm{ml}$ of HCL was added and allowed to reflux for 15 minutes. After cooling and filtration, dilution to volume was completed. Trace metal grade reagent and water was used throughout. Solutions were analyzed with a Jobin Yvon JY 70 Type III Inductively Coupled Plasma Atomic Emission Spectrophotometer (ICP-AES) for $\mathrm{Na}, \mathrm{Ca}, \mathrm{Fe}, \mathrm{Mn}$, $\mathrm{Mg}, \mathrm{Mo}, \mathrm{V}, \mathrm{Cr}, \mathrm{Cu}, \mathrm{Ni}, \mathrm{Zn}$ and $\mathrm{Sr}$ with a precision of $\pm 5 \%$ for major elements, and $\pm 7 \%$ for trace metals.

Stable isotope analyses of Carbon were carried out on the organic fraction with a Finnigan Delta C EA-IRMS (with TC/EA). For the stable isotope analyses, we utilized a technique that uses $0.1-90 \mathrm{mg}$ of powdered rock per run. Each sample was treated with $\mathrm{HCl}$ to remove carbonate fraction and sulphur present in the rock. Oxidation was induced between $850-1000^{\circ} \mathrm{C}$ in a stream of oxygen, or in the presence of a $\mathrm{CuO}$ catalyst. Ratios obtained were compared repeatedly with a laboratory reference gas under identical conditions and values are presented as a deviation of the PDB "Peedee Belemnite" standard. 
Biomarker analyses were conducted for rock samples with at least $100 \mathrm{mg}$ of organic carbon. The rock powder was weighed and extracted in dichloromethane for 24 hours in a Soxhlet apparatus, where a known quantity of internal standard squalene was added. The extract obtained was concentrated through rotary-evaporation under vacuum at $30^{\circ} \mathrm{C}$; the extract was then saponified with $25 \mathrm{ml}$ of $1 \mathrm{~N} \mathrm{KOH}$ to separate the acids from the neutral lipid fractions (Jaffe et al., 2001). After elution with hexane, the hydrocarbon fraction was run on a GC/MS on a HP 6890 GC interfaced to an HP 5973 quadrupole scanning mass spectrometer. A 5\% phenyl methylsilicon bonded phase (J \& W DB-5MS) fused silica capillary column $(30 \mathrm{~m} \times 0.25 \mathrm{~mm}$ i.d. $\times 0.25 \mu \mathrm{m}$ film thickness $)$ was used for the separation. The $\mathrm{GC}$ oven was programmed to hold initial temperature of $40^{\circ} \mathrm{C}$ for $1 \mathrm{~min}$, and then ramped at a rate of $6^{\circ} \mathrm{C} / \mathrm{min}$ to a final temperature of $300^{\circ} \mathrm{C}$ held for $20 \mathrm{~min}$. Chromatograms of the results were analyzed and identified by comparison with the Wiley275 mass spectra library.

\subsection{Results}

\subsubsection{Petrography and SEM Descriptions}

Microfacies observations of the finely laminated rocks of the Indidura Formation reveals the presence of persistent 1 to 2 mm-thick, dark, and light parallel laminae (Figure 8- 3 B,C). They are arranged in quasi-periodic intercalations of even parallel to wavy-parallel, light and dark bundles that resemble those found in varve deposits. The later is observed more readily in the highly laminated calcilutites, where individual laminae can be followed laterally for several decimeters. Indeed, the conspicuous laminae seen at the macroscopic scale are in fact not continuous; they occur as uneven discrete units with 
pinch and swell structures (Figure 8-4). Close observation of the light laminae shows that they are almost entirely ( $>90 \%)$ composed of calcite-filled "microspheroids"
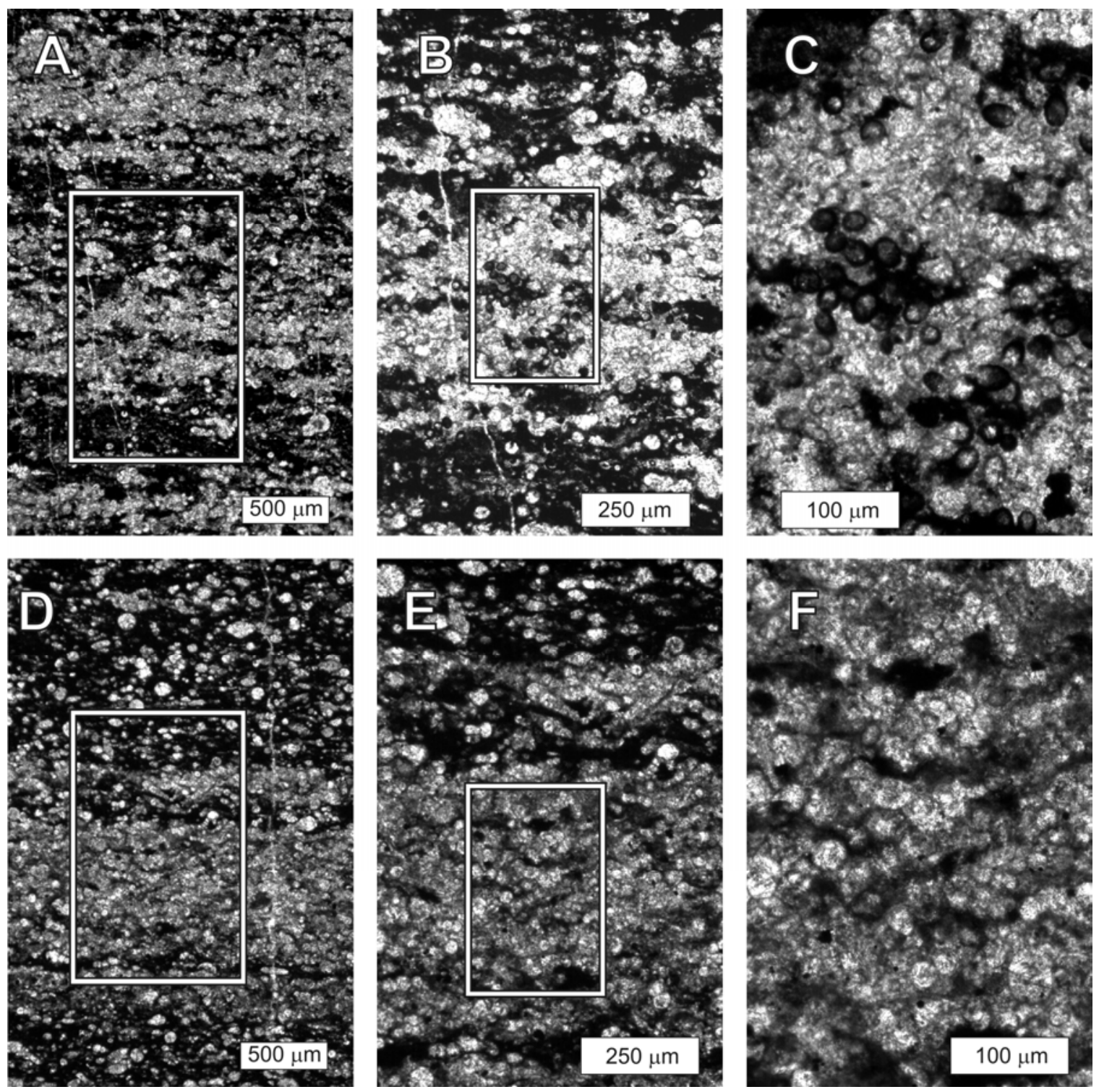

Figure 8- 4. A, D Thin sections microphotographs of highly laminated calcilutite: Parallel to even parallel laminae very thin laminae $<3 \mathrm{~mm}$., that show pinch and swell structures. Laminae forms couplets that resemble "varves". B and E correspond to magnifications of A, D respectively, microspheroids from a close framework with some pockets of organic matter in between. $\mathrm{C}$ and $\mathrm{F}$ are close-ups of B and $\mathrm{E}$ respectively; all microspheroids have a size between 20-40 $\mu \mathrm{m}$, but are consistently around $25 \mu \mathrm{m}$; note that in most cases microspheroids have a coating and shape that similar to those of Precambrian cyanophyte. All scales inside figures. 
between $5-100 \mu \mathrm{m}$, with a predominant size range of 20 to $40 \mu \mathrm{m}$, and a median size of $20 \mu \mathrm{m}$ (Figure 8-4). The granular components or "microspheroids" are less abundant in the dark laminae, which also include scattered planktonic foraminifera (mainly heterohelicids), and scarce radiolarians. The darker laminae are usually made of 30 to $50 \%$ of undifferentiated clay-size particles, and up to $5 \%$ scattered framboidal pyrite aggregates. They also include microsparite as the main cement, although sparry calcite may be found indiscriminately in microfractures.

Further characterization of the microscopic components of the Indidura Formation at Parras was accomplished by scanning electron microscopy (SEM) analysis carried out in marlstones and shaly calcilutites. At higher magnification, it becomes clear that both rock types are unequivocally composed of microspheroids with spherical, semi-spherical, and ovoidal shapes that range in size from 20-50 $\mu \mathrm{m}$ (Figure 8- 5). These images also reveal that the microspheroids are mainly scattered in the dark laminae and marlstones where they make up a lesser proportion of the sediment components. In comparison, images from the shaly calcilutites show the same microspheroid components as the marls, but additionally show a complex framework that binds together microspheroids as aggregates or strings of spheroids (Figure 8- 5 F,L). Higher magnification images disclose that most of these structures consistently have a 3 to $5 \mu \mathrm{m}$ rim of microcrystalline calcite that is reminiscent of a test; however, further examination of these ultrastructures shows no organized microcrystalline arrangement (Figure 8- 5 C,E). 

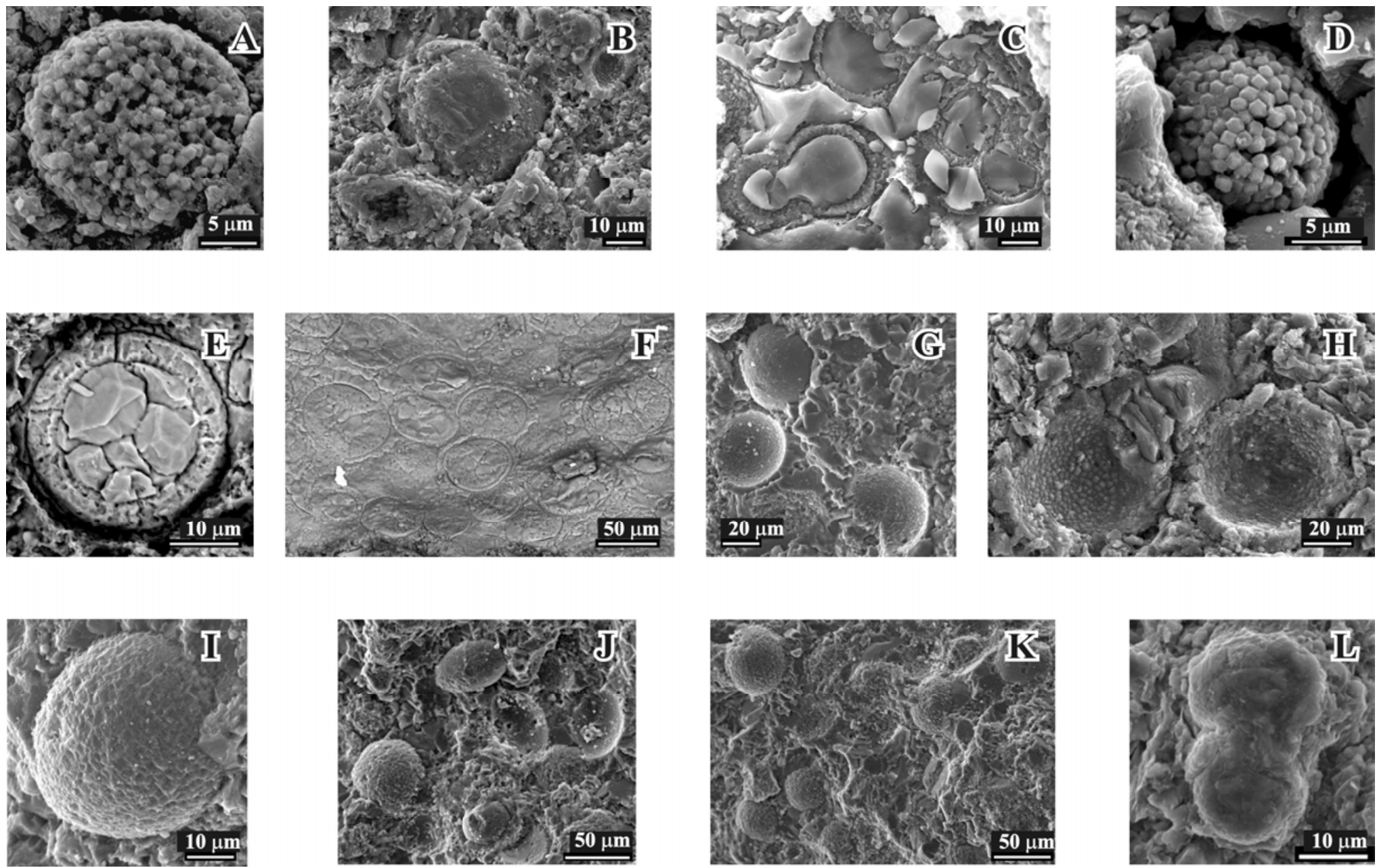

Figure 8- 5. SEM images showing different shapes of microspheroids: spherical (all images), semispherical and ovoid (J,K,L). Those on

(C,E,F) exhibit a 3 to $5 \mu \mathrm{m}$ rim of microcrystalline calcite that is reminiscent of a test. Microspheroids are made up of single crystal (C,E,F,L) or multiple crystals of sparry calcite $(\mathrm{A}, \mathrm{B}, \mathrm{D}, \mathrm{G}, \mathrm{H}, \mathrm{I}, \mathrm{J}, \mathrm{K})$; they are found isolated $(\mathrm{A}, \mathrm{B}, \mathrm{D}, \mathrm{E}, \mathrm{F}, \mathrm{G}, \mathrm{H}, \mathrm{J}, \mathrm{K})$ or as aggregates that resemble strings of attached cells $(\mathrm{C}, \mathrm{F}, \mathrm{L})$. All scales inside the figures. 


\subsubsection{Geochemistry}

\subsubsection{Organic Matter and Inorganic Carbon}

The total organic carbon (TOC) and carbonate $\left(\mathrm{CaCO}_{3}\right)$ varies in a rhythmic pattern concurrent with the different contrasting lithologies (Figure 8- 6). Thus carbonate values vary from $27 \%$ to $91 \%$ with a median of $70 \%$, and TOC content fluctuates between $0.3 \%$ and $3.6 \%$, most commonly higher than $1.6 \%$. Temporal $\mathrm{TOC}$ and $\mathrm{CaCO}_{3}$ changes in the sequence show an overall increase in the organic matter content toward the middle Turonian (L. maleformis), where the maximum values are reached for both marlstones and clayey biocalcilutites. Higher TOC and lower $\mathrm{CaCO}_{3}$ values are consistently found in the less laminated shaly marlstone beds, while a reverse trend is observed for the highly laminated biocalcilutite layers where microspheroids are prevalent. Also, a marked increase in TOC corresponds to the stratigraphic level where microspheroids increase to more than $50 \%$ in the laminated calcilutites, and about $20 \%$ of the marls. Although the laminated biocalcilutites show relatively lower carbonate values than the marls, their absolute values are higher once correction is made for the TIC dilution factor.

\subsubsection{Biomarkers and Stable Isotopes}

Biomarker analyses reveal that the composition of the organic matter present in the rocks of the Indidura Formation has a predominant presence of algae and other marine plankton. Chromatographs (Figure 8- 7) show bimodal distributions in the n-alkanes where the major proportions are represented by $\mathrm{C} 12$ to $\mathrm{C} 17$ n-alkanes, which are characteristic of marine plankton, and more specifically bacterial origin (Peters et al., 2005). Minor abundances of $\mathrm{C} 27$ to $\mathrm{C} 34 \mathrm{n}$-alkanes indicate some predominance of land- 


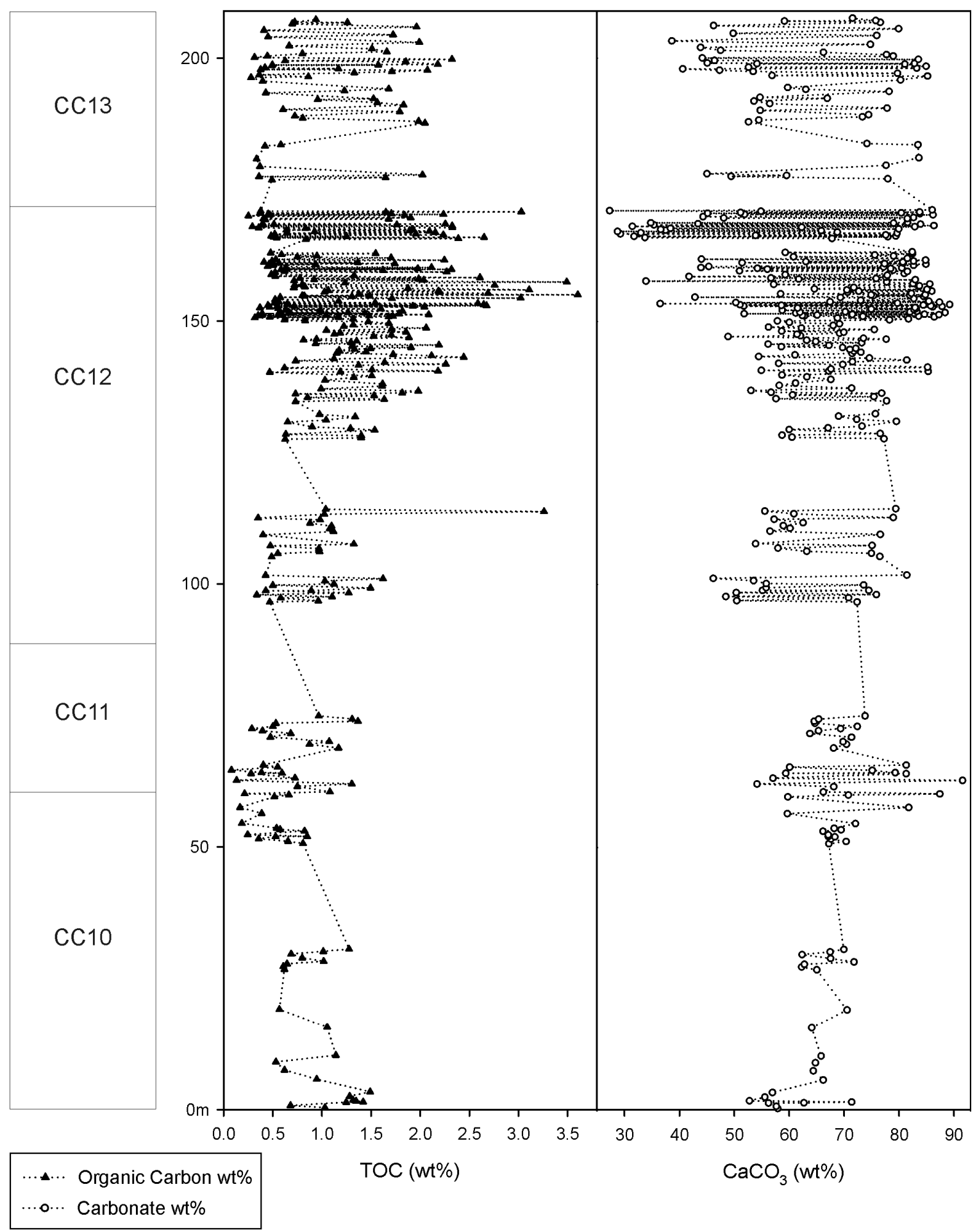

Figure 8- 6. TOC shows a marked increase toward the top of the L. maleformis (CC12 zone), where values become consistently higher for both $\mathrm{TOC}$ and $\mathrm{CaCO}_{3}$. This zone also corresponds with the higher abundances of microspheroids. 

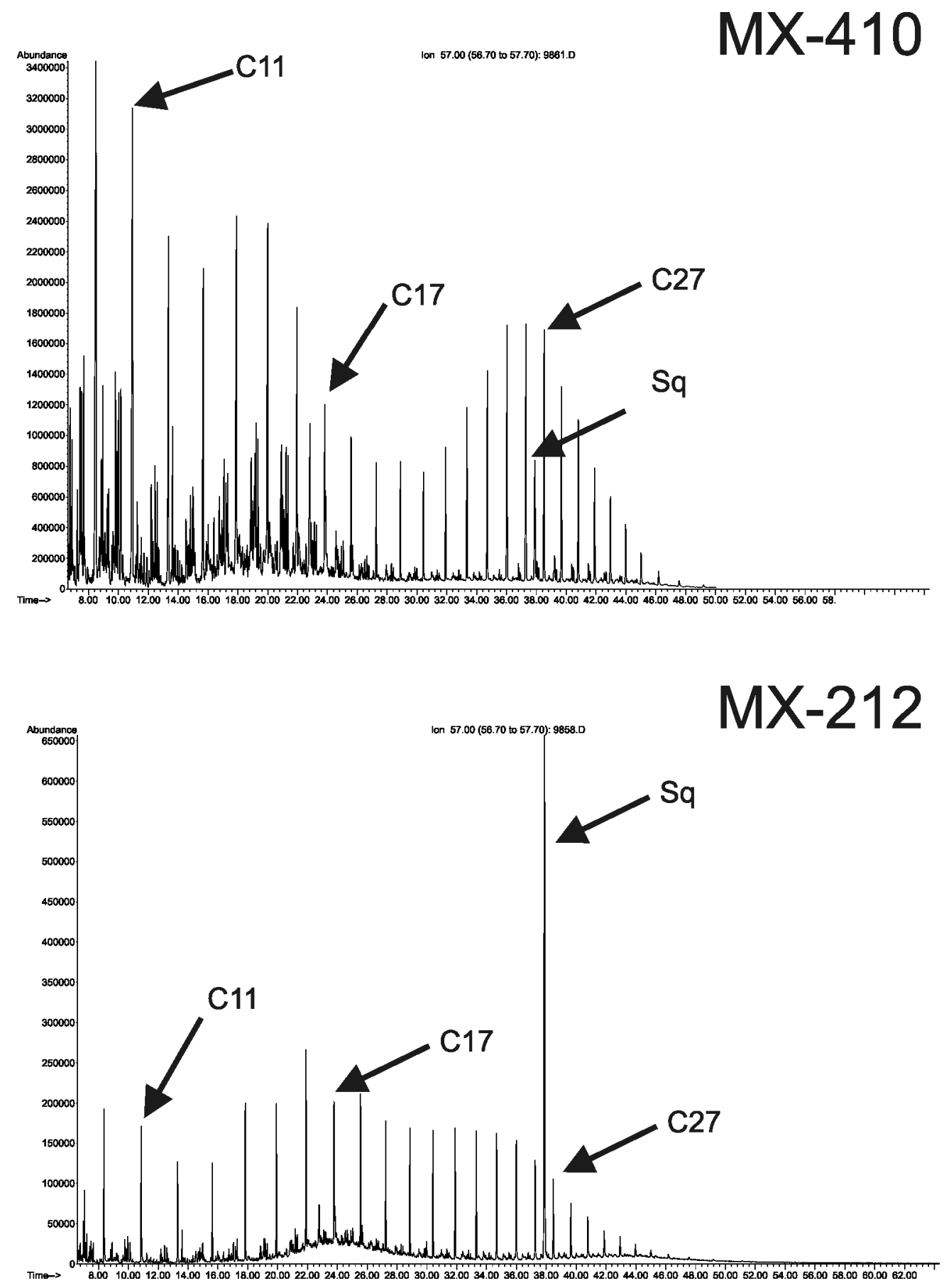

Figure 8- 7. Gas chromatograph of ion 57. arrows indicate the n-alkanes present in the samples MX-212 and MX-410. Lower molecular carbon chains are predominant in both of samples. MX212 shows more of a normal distribution while, MX-410 is bimodal. Both samples are dominated by low molecular n-alkanes. 
derived detritus. All of the pristane/phytane ratios (Table 8- 1) are below the value of 1.0 which separates anoxic from dysoxic conditions (Didyck et al., 1978; Rowland, 1990).

\begin{tabular}{ccc}
\hline $\begin{array}{c}\text { Sample } \\
\#\end{array}$ & Pristane/Phytane & $\begin{array}{c}\text { TOC } \\
\text { (wt\%) }\end{array}$ \\
\hline \hline & & \\
MX-410 & 0.93 & 0.9 \\
MX-394 & 0.76 & 0.3 \\
MX-392 & 0.86 & 0.6 \\
MX-292 & 0.83 & 0.9 \\
MX-296 & 0.72 & 1.4 \\
MX-212 & 0.86 & 1.7 \\
MX-211 & 0.88 & 0.5 \\
MX-40 & 0.76 & 1.1 \\
\hline \hline
\end{tabular}

Table 8- 1. Pristane/Phytane ratios and total organic content.

Stable isotopes on the C-org fraction (Figure 8- 8) show values that are well within those reported for marine organic matter, with values ranging from about $-26.6 \%$ to $-25.7 \%$ for the upper of the Upper Cenomanian (the CC10 Calcareous Nannoplankton Zone). The Cenomanian/Turonian boundary interval (the CC11 Calcareous Nannoplankton Zone), includes values that range from $-26.7 \%$ to $-24.7 \%$ and correspond to the more enriched samples in $\delta^{13}$ Corg. For the low-mid Turonian interval (the CC12 Calcareous Nannofossil Zone), $\delta^{13} \mathrm{C}$ values return to background values close to $-26.5 \%$, although there is a second increase close to the upper part of this zone with values close to $-25.7 \%$. For the middle Turonian (the CC13 Calcareous Nannoplankton Zone) isotope values return to background values close to $-27 \%$. One distinctive feature of the $\delta^{13} \mathrm{C}$ is the depletion of $\approx 2 \%$ in values toward the upper part of the stratigraphic section, with firm positive excursions during the Lower Turonian and a second less pronounced excursion during the low- to mid-Turonian (Figure 8-8). 


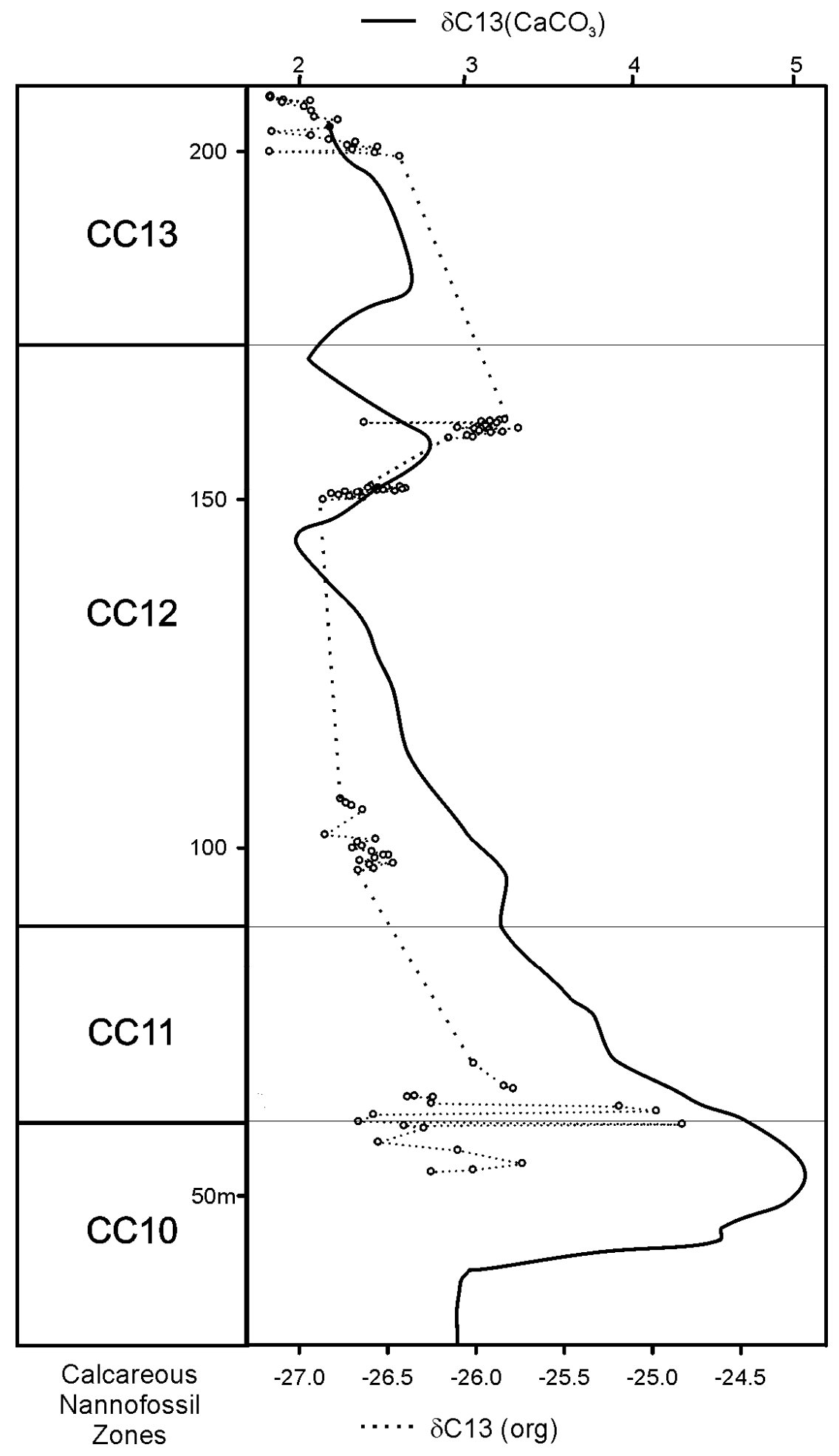

Figure 8- 8. $813 \mathrm{C}$ anomalies of Indidura Formation, the record shows a major positive excursion just above the lower part of the Q. gartneri zone CC11 (Cenomanian/Turonian boundary). A second less pronounced anomaly is found in the upper part of the L. maleformis zone CC12. $\delta^{13} \mathrm{C}\left(\mathrm{CaCO}_{3}\right)$ record after Voigt (2000) curve for Western Europe $\mathrm{C} / \mathrm{T}$ record. 


\subsubsection{Trace elements}

The organic-rich sedimentary rocks of the Indidura Formation at Parras are relatively enriched in trace metals (V, Mo, Ni, Cu, Zn, Cr), Table 8.2. For most of the section, there is a relationship between the $\mathrm{Mo}, \mathrm{V}, \mathrm{Cr}, \mathrm{Cu}, \mathrm{Mn}$, and to a less extent $\mathrm{Fe}$, where the lowest concentration of these trace elements occurs in the low-organic carbon intervals, and the highest in the high-organic levels (Table 8.2). Trace element indices of $\mathrm{V} / \mathrm{Cr}$ and $\mathrm{V} /(\mathrm{V}+\mathrm{Ni})$ ratios were compared to evaluate the paleoredox conditions as done by Hatch and Leventhal (1992) and Jones and Manning (1994). The latter authors suggest $\mathrm{V} / \mathrm{Cr}$ ratios of $<2.0$ to infer oxic conditions, 2.0 to 4.25 for dysoxic conditions and $>4.25$ for suboxic to anoxic conditions. Lewan (1984) argues that $\mathrm{V} /(\mathrm{V}+\mathrm{Ni})$ ratio $>0.5$ indicate that the organic matter accumulated under euxinic conditions; while Hatch and Leventhal (1992) suggest that water conditions were euxinic for ratios $>0.84$, anoxic for ratios between 0.54 and 0.84 , and dysoxic for ratios of 0.46 to 0.54 . Overall, most of the stratigraphic section (Table 8.2 and Figure 8- 9) has $\mathrm{V} /(\mathrm{V}+\mathrm{Ni}$ ) ratios $>0.5$ and $\mathrm{V} / \mathrm{Cr}$ ratios $>2.2$, that concur with the ratios indicated by Hatch and Leventhal (1992) for sediments that accumulated under low-oxygen conditions. Enriched and depleted zones for Mo, V, and $\mathrm{Cr}$ and indices for low oxygen content show good agreement within the zones where there is no discernible bioturbation.

\subsection{Discussion}

The microspheroids are consistently found throughout the stratigraphic section, but they start to become an important constituent of the rock already within the Lower Turonian (above the base of CC11 Calcareous Nannoplankton Zone), where the first finely 


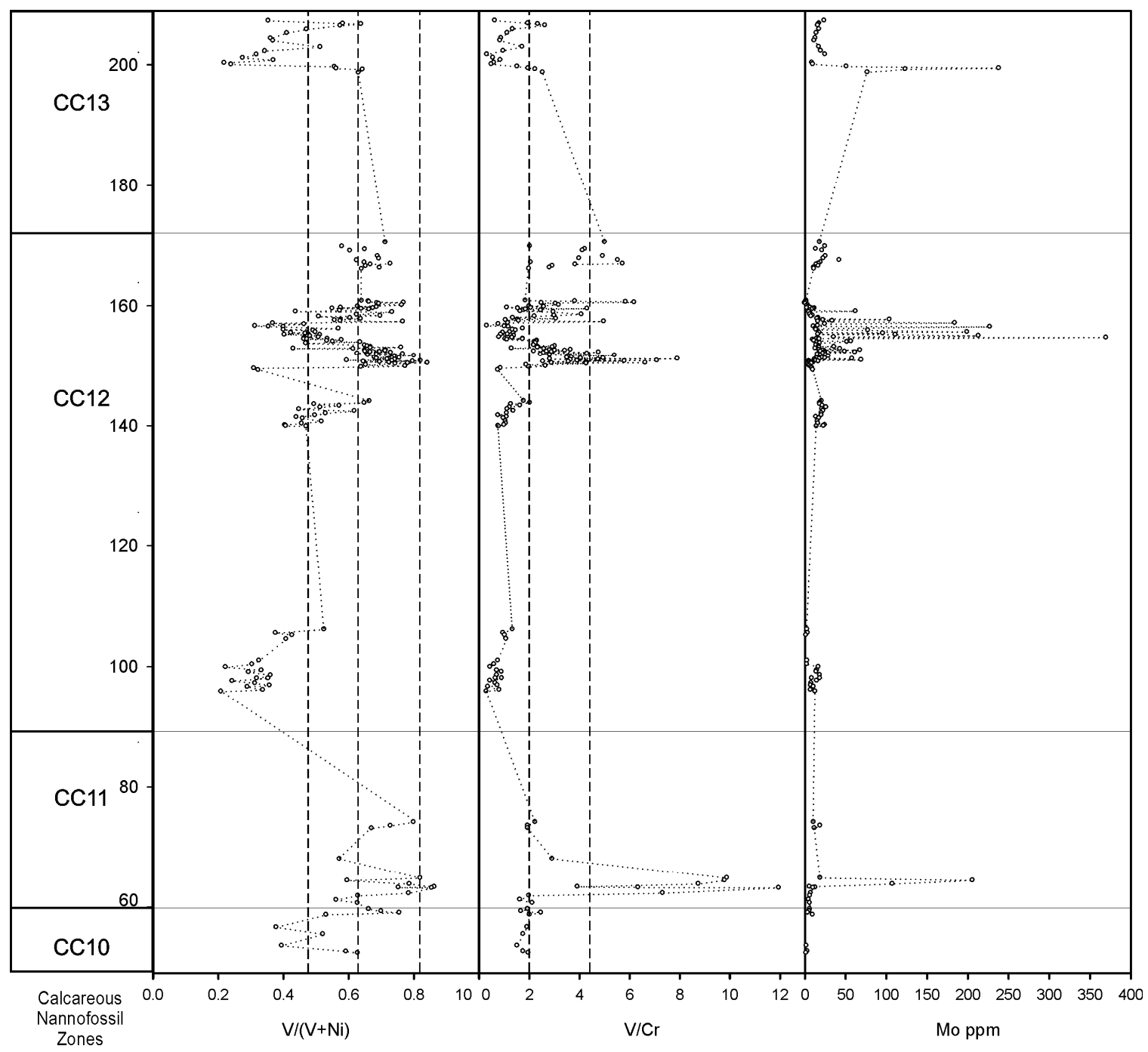

Figure 8- 9. Indidura Formation trace metals anomalies with respect to biostratigraphic position. Dashed line correspond to literature values of known anoxia indices of $\mathrm{V} /(\mathrm{V}+\mathrm{Ni})$ from Hatch and Leventhal (1992); and V/Cr from Jones and Manning (1994). The $\mathrm{C} / \mathrm{T}$ boundary is placed in the bottom of the $Q$. gartneri zone.

laminated marly calcilutites appear. Before that level, the microspheroids are found primarily as blobs floating in the matrix fraction of the marls. Above that level, microspheroids make up as much as $50 \%$ of the rock and $100 \%$ in some laminae. Microspheroid size, shape, and type in the rocks can be properly observed under the electron microscope. This intrinsical difficulty to observe and therefore to identify such 


\begin{tabular}{|c|c|c|c|c|c|c|c|c|c|c|c|c|c|c|c|c|c|c|c|}
\hline Sample \# & $\begin{array}{c}\text { Distance } \\
\text { Base }\end{array}$ & $\begin{array}{c}\text { Total } \\
\text { Carbonate } \\
\text { wt } \%\end{array}$ & $\begin{array}{c}\text { Total } \\
\text { Organic } \\
\text { Carbon } \\
w t \%\end{array}$ & $\begin{array}{c}\text { Non } \\
\text { Carbonate } \\
\text { Fraction } \\
w t \%\end{array}$ & $\delta^{13} \mathrm{C}_{\text {org }}$ & $\begin{array}{c}\text { Na } \\
(\mathbf{p p m})\end{array}$ & $\begin{array}{c}\mathbf{K} \\
\text { (ppm) }\end{array}$ & $\begin{array}{c}\text { Mo } \\
\text { (ppm) }\end{array}$ & $\begin{array}{c}\mathbf{Z n} \\
(\mathrm{ppm})\end{array}$ & $\begin{array}{c}\mathrm{Ni} \\
\text { (ppm) }\end{array}$ & $\begin{array}{c}\text { Mn } \\
(\mathbf{p p m})\end{array}$ & $\begin{array}{c}\mathbf{F e} \\
(\mathbf{p p m})\end{array}$ & $\begin{array}{c}\mathbf{C r} \\
(\mathrm{ppm})\end{array}$ & $\begin{array}{c}\mathrm{V} \\
(\mathrm{ppm})\end{array}$ & $\begin{array}{c}\mathrm{Cu} \\
(\mathrm{ppm})\end{array}$ & $\begin{array}{c}\mathrm{Al} \\
(\mathrm{ppm})\end{array}$ & $\begin{array}{c}\mathbf{S r} \\
(\mathbf{p p m})\end{array}$ & $\mathbf{V} /(\mathbf{V}+\mathbf{N i})$ & $\mathrm{V} / \mathrm{Cr}$ \\
\hline MX-410 & 207.37 & 72 & $\overline{0.9}$ & 28 & -27.15 & 208 & 1312 & 24 & $\overline{55}$ & 36 & 60 & 6392 & 31 & 20 & $\overline{6}$ & 1303 & 637 & 0.35 & $\overline{0.64}$ \\
\hline MX-409 & 206.90 & 76 & 0.7 & 24 & -27.08 & 156 & 1207 & 18 & 20 & 21 & 64 & 6528 & 15 & 29 & 4 & 1479 & 616 & 0.58 & 1.95 \\
\hline MX-407 & 206.80 & 59 & 1.3 & 40 & -26.93 & 197 & 2383 & 17 & 66 & 23 & 66 & 610441 & 17 & 41 & 11 & 2947 & 559 & 0.64 & 2.35 \\
\hline MX-406 & 206.56 & 77 & 0.7 & 23 & -27.09 & 184 & 842 & 16 & 18 & 19 & 59 & 9340 & 10 & 26 & 3 & 889 & 623 & 0.57 & 2.64 \\
\hline MX-405 & 205.95 & 46 & 2.0 & 52 & -26.96 & 232 & 2709 & 18 & 53 & 33 & 44 & 8375 & 22 & 29 & 14 & 3251 & 442 & 0.47 & 1.35 \\
\hline MX-404 & 205.33 & 80 & 0.4 & 20 & -26.92 & 167 & 788 & 14 & 8 & 12 & 53 & 4079 & 8 & 9 & 2 & 894 & 624 & 0.41 & 1.13 \\
\hline MX-402 & 204.47 & 50 & 1.7 & 48 & -26.90 & 171 & 2571 & 13 & 58 & 28 & 53 & 9318 & 18 & 16 & 13 & 3089 & 426 & 0.36 & 0.89 \\
\hline MX-401 & 204.07 & 76 & 0.5 & 24 & -26.77 & 167 & 982 & 12 & 17 & 14 & 68 & 5461 & 10 & 8 & 3 & 1171 & 613 & 0.37 & 0.84 \\
\hline MX-400 & 203.04 & 39 & 2.0 & 59 & -26.82 & 180 & 2883 & 17 & 60 & 30 & 46 & 8547 & 18 & 32 & 18 & 3924 & 341 & 0.51 & 1.73 \\
\hline MX-399 & 202.38 & 75 & 0.7 & 25 & -27.15 & 166 & 1199 & 20 & 22 & 27 & 72 & 4937 & 14 & 14 & 3 & 1686 & 666 & 0.34 & 0.97 \\
\hline MX-398 & 201.80 & 44 & 1.5 & 55 & -26.92 & 136 & 2494 & 25 & 72 & 40 & 43 & 9841 & 58 & 19 & 14 & 4494 & 383 & 0.32 & 0.32 \\
\hline MX-397 & 201.25 & 48 & 1.7 & 51 & -26.82 & 165 & 2296 & & 45 & 35 & 45 & 6466 & 24 & 13 & 13 & 3273 & 415 & 0.28 & 0.56 \\
\hline MX-396 & 200.87 & 66 & 0.8 & 33 & -26.67 & 149 & 1483 & - & 28 & 16 & 61 & 6249 & 11 & 10 & 5 & 1819 & 646 & 0.37 & 0.85 \\
\hline MX-395 & 200.43 & 78 & 0.4 & 22 & -26.72 & 190 & 1051 & 9 & 33 & 22 & 59 & 6835 & 10 & 6 & 4 & 1262 & 612 & 0.22 & 0.60 \\
\hline MX-394 & 200.17 & 79 & 0.3 & 21 & -26.55 & 147 & 953 & 10 & 12 & 31 & 72 & 6366 & 20 & 10 & 4 & 1143 & 626 & 0.24 & 0.50 \\
\hline MX-393 & 199.80 & 44 & 2.3 & 54 & -26.69 & 140 & 2694 & 51 & 48 & 28 & 37 & 8791 & 23 & 35 & 15 & 3211 & 409 & 0.56 & 1.53 \\
\hline MX-392 & 199.52 & 84 & 0.6 & 16 & -27.16 & - & - & 238 & 20 & 16 & 64 & 410362 & 10 & 20 & 5 & 826 & 714 & 0.56 & 1.97 \\
\hline MX-391 & 199.34 & 46 & 1.9 & 52 & -26.56 & 202 & 1836 & 124 & 71 & 22 & 48 & 87491 & 17 & 39 & 12 & 2603 & 461 & 0.64 & 2.24 \\
\hline MX-389 & 198.84 & 45 & 2.2 & 53 & -26.42 & 108 & 2485 & 77 & 71 & 28 & 39 & 6574 & 19 & 48 & 9 & 2641 & 434 & 0.63 & 2.54 \\
\hline MX-349 & 170.81 & 27 & 3.0 & 70 & - & 171 & 3813 & 19 & 48 & 20 & 25 & 8567 & 10 & 49 & 13 & 5223 & 219 & 0.71 & 5.02 \\
\hline MX-341 & 170.13 & 52 & 1.8 & 46 & - & 131 & 2267 & 25 & 23 & 16 & 32 & 27765 & 11 & 23 & 8 & 2749 & 559 & 0.58 & 2.04 \\
\hline MX-339 & 169.67 & 44 & 1.9 & 54 & - & 157 & 3313 & 14 & 31 & 19 & 31 & 10081 & 8 & 35 & 11 & 4679 & 418 & 0.65 & 4.23 \\
\hline MX-336 & 169.43 & 48 & 1.7 & 50 & - & 135 & 2765 & 21 & 41 & 24 & 41 & 10132 & 9 & 37 & 12 & 3143 & 378 & 0.60 & 4.13 \\
\hline MX-332 & 168.51 & 35 & 2.3 & 63 & - & 135 & 3507 & 26 & 44 & 21 & 32 & 28143 & 10 & 48 & 12 & 3653 & 248 & 0.69 & 4.94 \\
\hline MX-328 & 168.12 & 35 & 2.3 & 62 & - & 160 & 4141 & 23 & 102 & 23 & 32 & 27033 & 13 & 52 & 13 & 4764 & 279 & 0.69 & 4.00 \\
\hline MX-326 & 167.83 & 31 & 2.3 & 66 & - & 122 & 4037 & 42 & 52 & 26 & 37 & $7 \quad 11375$ & 8 & 43 & 13 & 5542 & 220 & 0.63 & 5.54 \\
\hline MX-323 & 167.47 & 38 & 1.9 & 60 & - & 181 & 3185 & 20 & 44 & 19 & 32 & 24988 & 17 & 36 & 5 & 3752 & 334 & 0.65 & 2.07 \\
\hline MX-321 & 167.26 & 37 & 1.9 & 61 & - & 142 & 3770 & 17 & 32 & 14 & 35 & 7595 & 6 & 37 & 10 & 4803 & 314 & 0.73 & 5.73 \\
\hline MX-320 & 167.13 & 38 & 2.1 & 60 & - & 136 & 3269 & 14 & 33 & 16 & 36 & 8499 & 8 & 32 & 11 & 4022 & 342 & 0.67 & 3.84 \\
\hline MX-318 & 166.89 & 29 & 2.2 & 69 & - & 127 & 3103 & 17 & 39 & 16 & 30 & 8868 & 10 & 29 & 10 & 4533 & 257 & 0.65 & 2.93 \\
\hline MX-316 & 166.62 & 33 & 2.0 & 65 & - & 119 & 2804 & 11 & 37 & 14 & 35 & 8265 & 11 & 32 & 9 & 3953 & 288 & 0.70 & 2.82 \\
\hline MX-314 & 166.42 & 29 & 2.2 & 69 & - & 144 & 2677 & 11 & 79 & 14 & 29 & 8094 & 13 & 26 & 11 & 3122 & 254 & 0.64 & 1.99 \\
\hline MX-296 & 161.17 & 63 & 1.4 & 36 & -25.83 & 143 & 1955 & 2 & 34 & 18 & 50 & 7766 & 17 & 32 & 6 & 1801 & 585 & 0.64 & 1.86 \\
\hline
\end{tabular}

Table 8-2. Indidura Formation, sample stratigraphic assignment, stable isotopes and elemental concentrations. 


\begin{tabular}{|c|c|c|c|c|c|c|c|c|c|c|c|c|c|c|c|c|c|c|c|}
\hline Sample \# & $\begin{array}{c}\text { Distance } \\
\text { Base }\end{array}$ & $\begin{array}{c}\text { Total } \\
\text { Carbonate } \\
\text { wt } \%\end{array}$ & $\begin{array}{c}\text { Total } \\
\text { Organic } \\
\text { Carbon } \\
w t \%\end{array}$ & $\begin{array}{c}\text { Non } \\
\text { Carbonate } \\
\text { Fraction } \\
\text { wt } \%\end{array}$ & $\delta^{13} \mathrm{C}_{\text {org }}$ & $\begin{array}{c}\mathrm{Na} \\
(\mathrm{ppm})\end{array}$ & $\begin{array}{c}\mathbf{K} \\
(\mathbf{p p m})\end{array}$ & $\begin{array}{c}\text { Mo } \\
\text { (ppm) }\end{array}$ & $\begin{array}{c}\mathbf{Z n} \\
(\mathrm{ppm})\end{array}$ & $\begin{array}{c}\mathrm{Ni} \\
(\mathrm{ppm})\end{array}$ & $\begin{array}{c}\text { Mn } \\
(\mathrm{ppm})\end{array}$ & $\begin{array}{c}\mathrm{Fe} \\
(\mathbf{p p m})\end{array}$ & $\begin{array}{c}\mathrm{Cr} \\
(\mathrm{ppm})\end{array}$ & $\begin{array}{c}\mathrm{V} \\
(\mathrm{ppm})\end{array}$ & $\begin{array}{c}\mathrm{Cu} \\
(\mathrm{ppm})\end{array}$ & $\begin{array}{c}\mathbf{A l} \\
(\mathbf{p p m})\end{array}$ & $\begin{array}{c}\mathrm{Sr} \\
(\mathrm{ppm})\end{array}$ & $\mathbf{V} /(\mathbf{V}+\mathbf{N i})$ & $\mathrm{V} / \mathrm{Cr}$ \\
\hline$\overline{M X-295}$ & 161.07 & 81 & $\overline{0.6}$ & 19 & -25.86 & 159 & 7770 & 2 & 115 & 16 & $\overline{45}$ & 3964 & 8 & 31 & 0 & 890 & 642 & 0.66 & 3.83 \\
\hline MX-294 & 160.96 & 51 & 1.7 & 47 & -25.91 & 128 & 2339 & - & 56 & 16 & 43 & 8397 & 5 & 31 & 8 & 2435 & 419 & 0.66 & 5.85 \\
\hline MX-293 & 160.86 & 81 & 0.5 & 19 & -25.96 & 160 & 790 & 2 & 88 & 9 & 45 & 3313 & 5 & 32 & & 809 & 672 & 0.77 & 6.20 \\
\hline MX-292 & 160.77 & 77 & 0.9 & 22 & -26.62 & 174 & 1832 & 0 & 66 & 14 & 54 & 8577 & 12 & 30 & 4 & 1973 & 604 & 0.69 & 2.49 \\
\hline MX-291 & 160.66 & 85 & 0.5 & 15 & -25.87 & 154 & 669 & 1 & 172 & 11 & 48 & 2545 & 8 & 26 & - & 573 & 675 & 0.69 & 3.06 \\
\hline MX-290 & 160.43 & 83 & 0.4 & 17 & -25.94 & 147 & 882 & 4 & 10 & 9 & 55 & 3559 & 9 & 28 & - & 1017 & 612 & 0.76 & 3.18 \\
\hline MX-289 & 160.23 & 45 & 2.1 & 53 & -25.93 & 115 & 2316 & 3 & 43 & 16 & 40 & 6084 & 13 & 27 & 8 & 2158 & 398 & 0.63 & 2.01 \\
\hline MX-288 & 160.13 & 77 & 0.6 & 22 & -25.98 & 192 & 1053 & 5 & 8 & 10 & 51 & 3245 & 8 & 21 & & 1050 & 620 & 0.69 & 2.59 \\
\hline MX-287 & 160.01 & 44 & 2.0 & 54 & -26.09 & 179 & 2537 & 7 & 35 & 16 & 40 & 7412 & 20 & 22 & 8 & 2632 & 393 & 0.58 & 1.12 \\
\hline MX-286 & 159.93 & 80 & 0.6 & 19 & -25.75 & 180 & 1268 & 3 & 17 & 15 & 49 & 4180 & 15 & 31 & 1 & 1355 & 687 & 0.68 & 2.07 \\
\hline MX-285 & 159.88 & 54 & 2.3 & 43 & -25.96 & 182 & 2523 & 12 & 34 & 22 & 46 & 8547 & 17 & 27 & 8 & 2384 & 509 & 0.55 & 1.55 \\
\hline MX-284 & 159.83 & 78 & 0.6 & 21 & -26.00 & 176 & 1084 & 11 & 10 & 14 & 49 & 3875 & 6 & 26 & 1 & 1165 & 609 & 0.64 & 4.32 \\
\hline MX-283 & 159.71 & 56 & 1.6 & 42 & -25.91 & 180 & 2427 & 9 & 25 & 13 & 40 & 5166 & 13 & 25 & 6 & 2278 & 516 & 0.66 & 1.87 \\
\hline MX-282 & 159.53 & 79 & 0.6 & 20 & -25.97 & 206 & 1113 & 6 & 11 & 11 & 54 & 3884 & 6 & 15 & 3 & 1100 & 622 & 0.57 & 2.47 \\
\hline MX-281 & 159.39 & 51 & 2.3 & 47 & -25.84 & - & - & 62 & 32 & 30 & 44 & 11283 & 14 & 23 & 18 & 2983 & 494 & 0.44 & 1.65 \\
\hline MX-280 & 159.29 & 82 & 0.5 & 18 & -25.90 & 210 & 1025 & 5 & 19 & 8 & 45 & 2381 & 8 & 23 & 4 & 854 & 697 & 0.73 & 2.97 \\
\hline MX-279 & 158.88 & 81 & 0.5 & 19 & -26.04 & 178 & 854 & 6 & 7 & 8 & 49 & 2270 & 3 & 14 & 1 & 970 & 621 & 0.63 & 4.09 \\
\hline MX-278 & 158.68 & 59 & 1.3 & 39 & -26.01 & 268 & 2291 & 10 & 18 & 13 & 59 & 6183 & 10 & 29 & 5 & 2332 & 516 & 0.70 & 3.00 \\
\hline MX-277 & 158.56 & 78 & 0.5 & 22 & -26.15 & 185 & 1020 & 8 & 19 & 15 & 49 & 2412 & 7 & 16 & 2 & 945 & 613 & 0.51 & 2.22 \\
\hline MX-276 & 158.31 & 42 & 2.6 & 56 & - & 198 & 3405 & 17 & 44 & 19 & 30 & 5745 & 21 & 29 & 10 & 3232 & 360 & 0.61 & 1.35 \\
\hline MX-275 & 158.17 & 78 & 0.8 & 22 & - & 197 & 1196 & 15 & 24 & 11 & 40 & 1639 & 6 & 19 & 1 & 744 & 564 & 0.64 & 3.07 \\
\hline MX-274 & 158.04 & 57 & 2.0 & 41 & - & 164 & 2990 & 104 & 21 & 21 & 35 & 8900 & 19 & 29 & 12 & 2819 & 518 & 0.58 & 1.55 \\
\hline MX-273 & 157.94 & 76 & 0.9 & 23 & - & 225 & 1523 & 23 & 12 & 19 & 45 & 5710 & 23 & 24 & 3 & 1081 & 591 & 0.56 & 1.07 \\
\hline MX-272 & 157.82 & 62 & 2.0 & 36 & - & 206 & 1969 & 34 & 23 & 22 & 36 & 6737 & 19 & 29 & 9 & 1993 & 548 & 0.58 & 1.59 \\
\hline MX-271 & 157.72 & 83 & 0.7 & 16 & - & 275 & 1239 & 16 & 7 & 10 & 40 & 1690 & 6 & 31 & 2 & 923 & 634 & 0.77 & 4.98 \\
\hline MX-270 & 157.46 & 34 & 3.5 & 63 & - & 163 & 3047 & 184 & 31 & 29 & 35 & 9830 & 14 & 17 & 13 & 3594 & 269 & 0.37 & 1.16 \\
\hline MX-269C & 157.29 & 78 & 1.2 & 21 & - & 218 & 1244 & 25 & 7 & 15 & 80 & 8499 & 17 & 13 & 2 & 1027 & 513 & 0.46 & 0.78 \\
\hline MX-269B & 157.00 & 83 & 0.8 & 17 & - & 227 & 909 & 16 & 7 & 15 & 45 & 5389 & 21 & 7 & 2 & 691 & 580 & 0.31 & 0.31 \\
\hline MX-269A & 156.90 & 86 & 0.7 & 14 & - & 165 & 826 & 11 & 11 & 13 & 40 & 3139 & 7 & 7 & 1 & 558 & 642 & 0.36 & 1.02 \\
\hline MX-268 & 156.83 & 57 & 2.8 & 40 & - & 189 & 3648 & 227 & 33 & 26 & 42 & 10078 & 15 & 18 & 11 & 3782 & 531 & 0.40 & 1.18 \\
\hline MX-267 & 156.55 & 84 & 0.8 & 15 & - & 182 & 877 & 13 & 15 & 13 & 33 & 9968 & 9 & 17 & 2 & 636 & 678 & 0.57 & 1.75 \\
\hline MX-266 & 156.36 & 84 & 0.7 & 16 & - & 200 & 1005 & 14 & 23 & 14 & 32 & 3524 & 7 & 10 & 2 & 714 & 630 & 0.40 & 1.34 \\
\hline MX-265 & 156.25 & 72 & 1.9 & 26 & - & 206 & 2183 & 78 & 13 & 17 & 46 & 6734 & 11 & 17 & 4 & 1706 & 512 & 0.49 & 1.47 \\
\hline
\end{tabular}

Table 8-2. Indidura Formation, sample stratigraphic assignment, stable isotopes and elemental concentrations (continued). 


\begin{tabular}{|c|c|c|c|c|c|c|c|c|c|c|c|c|c|c|c|c|c|c|c|}
\hline Sample \# & $\begin{array}{c}\text { Distance } \\
\text { Base }\end{array}$ & $\begin{array}{l}\text { Total } \\
\text { Carbonate } \\
\text { wt } \%\end{array}$ & $\begin{array}{c}\text { Total } \\
\text { Organic } \\
\text { Carbon } \\
\text { wt } \%\end{array}$ & $\begin{array}{c}\text { Non } \\
\text { Carbonate } \\
\text { Fraction } \\
\text { wt } \%\end{array}$ & $\delta^{13} \mathrm{C}_{\mathrm{org}}$ & $\begin{array}{c}\mathrm{Na} \\
\text { (ppm) }\end{array}$ & $\begin{array}{c}\mathbf{K} \\
(\mathbf{p p m})\end{array}$ & $\begin{array}{c}\text { Mo } \\
\text { (ppm) }\end{array}$ & $\begin{array}{c}\mathbf{Z n} \\
(\mathrm{ppm})\end{array}$ & $\begin{array}{c}\mathbf{N i} \\
(\mathbf{p p m})\end{array}$ & $\begin{array}{c}\text { Mn } \\
(\mathbf{p p m})\end{array}$ & $\begin{array}{c}\mathrm{Fe} \\
(\mathbf{p p m})\end{array}$ & $\begin{array}{c}\mathbf{C r} \\
(\mathbf{p p m})\end{array}$ & $\begin{array}{c}\mathrm{V} \\
(\mathrm{ppm})\end{array}$ & $\begin{array}{c}\mathrm{Cu} \\
(\mathrm{ppm})\end{array}$ & $\begin{array}{c}\text { Al } \\
\text { (ppm) }\end{array}$ & $\begin{array}{c}\mathrm{Sr} \\
\text { (ppm) }\end{array}$ & $\mathbf{V} /(\mathbf{V}+\mathbf{N i})$ & $\mathrm{V} / \mathbf{C r}$ \\
\hline MX-264 & 155.98 & 65 & 3.1 & 32 & - & 171 & 2616 & 199 & 20 & 22 & $\overline{51}$ & 8813 & 18 & 22 & $\overline{6} 6$ & 2139 & 459 & 0.50 & 1.23 \\
\hline MX-263 & 155.87 & 85 & 1.1 & 14 & - & 170 & 734 & 18 & 9 & 11 & 32 & 3007 & 8 & 8 & 1 & 655 & 664 & 0.42 & 0.96 \\
\hline MX-262 & 155.75 & 71 & 2.2 & 27 & - & 183 & 2002 & 96 & 16 & 18 & 41 & 6712 & 12 & 16 & 6 & 2007 & 562 & 0.47 & 1.39 \\
\hline MX-261 & 155.56 & 86 & 1.0 & 13 & - & 172 & 720 & 17 & 30 & 11 & 31 & 2820 & 7 & 8 & 1 & 652 & 670 & 0.40 & 1.15 \\
\hline MX-260 & 155.52 & 73 & 2.2 & 25 & - & 172 & 1996 & 111 & 19 & 19 & 50 & 7111 & 23 & 20 & 5 & 1936 & 517 & 0.51 & 0.87 \\
\hline MX-259 & 155.33 & 71 & 2.7 & 27 & - & 196 & 1735 & 213 & 20 & 22 & 45 & 7289 & 14 & 20 & 7 & 1645 & 519 & 0.48 & 1.40 \\
\hline MX-258 & 155.13 & 82 & 1.4 & 16 & - & 174 & 1206 & 36 & 14 & 13 & 36 & $6 \quad 3986$ & 17 & 14 & 2 & 1080 & 598 & 0.51 & 0.80 \\
\hline MX-257 & 155.03 & 58 & 3.6 & 38 & - & 166 & 2344 & 370 & 29 & 28 & 46 & 610384 & 18 & 24 & 11 & 2519 & 396 & 0.46 & 1.33 \\
\hline MX-256 & 154.88 & 85 & 0.8 & 14 & - & 165 & 971 & 15 & 18 & 9 & 32 & $2 \quad 2249$ & 6 & 11 & 1 & 888 & 647 & 0.54 & 1.75 \\
\hline MX-255 & 154.83 & 75 & 1.5 & 24 & - & 169 & 1735 & 18 & 10 & 15 & 37 & 4672 & 12 & 13 & 5 & 1608 & 578 & 0.46 & 1.05 \\
\hline MX-254 & 154.79 & 82 & 0.8 & 17 & - & 190 & 660 & 18 & 10 & 13 & 25 & 514666 & 7 & 12 & 3 & 532 & 638 & 0.47 & 1.75 \\
\hline MX-253 & 154.69 & 75 & 1.3 & 23 & - & 157 & 1595 & 10 & 43 & 16 & 36 & $6 \quad 3648$ & 19 & 21 & 3 & 1616 & 717 & 0.58 & 1.12 \\
\hline MX-252 & 154.54 & 84 & 0.6 & 15 & - & 181 & 780 & 11 & 9 & 11 & 28 & 3769 & 5 & 12 & 2 & 655 & 612 & 0.53 & 2.31 \\
\hline MX-251 & 154.42 & 43 & 3.0 & 54 & - & 171 & 2325 & 57 & 34 & 25 & 32 & 212047 & 13 & 31 & 17 & 3816 & 388 & 0.55 & 2.29 \\
\hline MX-250 & 154.33 & 69 & 1.7 & 29 & - & 169 & 3239 & 52 & 15 & 17 & 33 & $3 \quad 6448$ & 14 & 30 & 7 & 2229 & 638 & 0.64 & 2.21 \\
\hline MX-249 & 154.12 & 83 & 0.5 & 17 & - & 173 & 766 & 19 & 19 & 15 & 26 & 8455 & 6 & 13 & 2 & 641 & 593 & 0.47 & 2.25 \\
\hline MX-248 & 153.80 & 73 & 1.2 & 26 & - & 157 & 1753 & 14 & 18 & 17 & 34 & 4071 & 14 & 31 & 4 & 1644 & 680 & 0.65 & 2.19 \\
\hline MX-247 & 153.64 & 85 & 0.6 & 14 & - & 190 & 655 & 17 & 7 & 9 & 28 & 3942 & 6 & 17 & 2 & 529 & 603 & 0.66 & 3.03 \\
\hline MX-246 & 153.52 & 67 & 1.5 & 31 & - & 152 & 2561 & 36 & 16 & 18 & 35 & 6278 & 15 & 36 & 7 & 2510 & 643 & 0.67 & 2.36 \\
\hline MX-245 & 153.45 & 87 & 0.5 & 12 & - & 181 & 707 & 18 & 12 & 7 & 24 & 1911 & 8 & 23 & 1 & 671 & 642 & 0.76 & 2.94 \\
\hline MX-244 & 153.38 & 50 & 2.6 & 47 & - & 166 & 4033 & 18 & 29 & 22 & 30 & 8681 & 19 & 45 & 11 & 4852 & 409 & 0.67 & 2.34 \\
\hline MX-243 & 153.26 & 80 & 0.6 & 20 & - & 159 & 641 & 13 & 16 & 21 & 24 & 423028 & 12 & 16 & 3 & 582 & 581 & 0.43 & 1.30 \\
\hline MX-242 & 153.18 & 37 & 2.6 & 61 & - & 146 & 4721 & 43 & 38 & 24 & 27 & $\begin{array}{ll}7 & 11338\end{array}$ & 15 & 39 & 17 & 6546 & 310 & 0.62 & 2.60 \\
\hline MX-241 & 153.01 & 89 & 0.5 & 10 & - & 171 & 582 & 18 & 6 & 7 & 27 & $7 \quad 2086$ & 5 & 18 & 1 & 591 & 679 & 0.71 & 3.66 \\
\hline MX-240 & 152.97 & 51 & 2.7 & 46 & - & 166 & 4529 & 68 & 35 & 25 & 37 & 9725 & 17 & 47 & 13 & 5288 & 434 & 0.65 & 2.82 \\
\hline MX-239 & 152.89 & 84 & 0.7 & 15 & - & 165 & 950 & 23 & 9 & 10 & 30 & 5502 & 8 & 25 & 2 & 1040 & 584 & 0.71 & 3.03 \\
\hline MX-238 & 152.86 & 59 & 1.9 & 40 & - & 145 & 4014 & 22 & 26 & 16 & 34 & 7642 & 11 & 39 & 10 & 4706 & 492 & 0.71 & 3.43 \\
\hline MX-237 & 152.76 & 86 & 0.5 & 14 & - & 159 & 1003 & 20 & 5 & 12 & 28 & 5597 & 10 & 22 & 2 & 990 & 555 & 0.65 & 2.19 \\
\hline MX-236 & 152.70 & 52 & 2.0 & 46 & - & 167 & 5164 & 49 & 27 & 21 & 33 & 9920 & 18 & 49 & 13 & 6578 & 436 & 0.70 & 2.71 \\
\hline MX-235 & 152.65 & 88 & 0.5 & 12 & - & 189 & 665 & 25 & 3 & 10 & 26 & 6329 & 7 & 20 & 2 & 616 & 610 & 0.67 & 2.90 \\
\hline MX-234 & 152.57 & 86 & 0.4 & 14 & - & 163 & 855 & 62 & 5 & 10 & 30 & 5469 & 6 & 27 & 2 & 830 & 705 & 0.73 & 4.77 \\
\hline MX-233 & 152.43 & 83 & 0.6 & 17 & - & - & - & 25 & 7 & 10 & 29 & 5768 & 7 & 18 & 2 & 700 & 568 & 0.63 & 2.57 \\
\hline MX-232 & 152.34 & 62 & 1.6 & 37 & - & 138 & 3299 & 22 & 31 & 13 & 44 & 8036 & 10 & 42 & 8 & 3513 & 480 & 0.77 & 4.32 \\
\hline
\end{tabular}

Table 8-2. Indidura Formation, sample stratigraphic assignment, stable isotopes and elemental concentrations (continued). 


\begin{tabular}{|c|c|c|c|c|c|c|c|c|c|c|c|c|c|c|c|c|c|c|c|}
\hline Sample \# & $\begin{array}{c}\text { Distance } \\
\text { Base }\end{array}$ & $\begin{array}{c}\text { Total } \\
\text { Carbonate } \\
\text { wt } \%\end{array}$ & $\begin{array}{c}\text { Total } \\
\text { Organic } \\
\text { Carbon } \\
\text { wt } \%\end{array}$ & $\begin{array}{c}\text { Non } \\
\text { Carbonate } \\
\text { Fraction } \\
\text { wt } \%\end{array}$ & $\delta^{13} \mathrm{C}_{\mathrm{org}}$ & $\begin{array}{c}\mathrm{Na} \\
(\mathrm{ppm})\end{array}$ & $\begin{array}{c}\mathbf{K} \\
(\mathbf{p p m})\end{array}$ & $\begin{array}{c}\text { Mo } \\
(\mathrm{ppm})\end{array}$ & $\begin{array}{c}\mathbf{Z n} \\
(\mathrm{ppm})\end{array}$ & $\begin{array}{c}\mathrm{Ni} \\
(\mathrm{ppm})\end{array}$ & $\begin{array}{c}\text { Mn } \\
(\mathbf{p p m})\end{array}$ & $\begin{array}{c}\mathrm{Fe} \\
(\mathrm{ppm})\end{array}$ & $\begin{array}{c}\mathrm{Cr} \\
(\mathrm{ppm})\end{array}$ & $\begin{array}{c}\mathrm{V} \\
(\mathrm{ppm})\end{array}$ & $\begin{array}{c}\mathrm{Cu} \\
(\mathrm{ppm})\end{array}$ & $\begin{array}{c}\mathbf{A l} \\
(\mathrm{ppm})\end{array}$ & $\begin{array}{c}\mathrm{Sr} \\
(\mathrm{ppm})\end{array}$ & $\mathbf{V} /(\mathbf{V}+\mathbf{N i})$ & $\mathrm{V} / \mathbf{C r}$ \\
\hline MX-231 & 152.25 & 83 & 0.6 & 16 & - & 118 & 904 & 16 & 8 & 9 & 37 & 2311 & $\overline{8}$ & 20 & 1 & 807 & 573 & 0.69 & 2.46 \\
\hline MX-230 & 152.12 & 75 & 1.0 & 24 & - & 115 & 1598 & 26 & 13 & 15 & 34 & 4681 & 10 & 29 & 4 & 1530 & 748 & 0.66 & 2.83 \\
\hline MX-229 & 152.05 & 83 & 0.6 & 17 & - & 165 & 1085 & 20 & 17 & 9 & 31 & 2085 & 6 & 35 & 1 & 1162 & 567 & 0.80 & 5.41 \\
\hline MX-228 & 151.93 & 59 & 1.8 & 39 & - & 193 & 2948 & 29 & 38 & 17 & 38 & 7481 & 14 & 50 & 10 & 3697 & 473 & 0.74 & 3.57 \\
\hline MX-227 & 151.71 & 83 & 0.6 & 16 & - & 159 & 955 & 21 & 14 & 9 & 33 & 3987 & 5 & 18 & 2 & 965 & 511 & 0.68 & 3.70 \\
\hline MX-226 & 151.64 & 70 & 1.3 & 29 & - & 138 & 2635 & 22 & 26 & 12 & 46 & 8473 & 11 & 38 & 7 & 2695 & 545 & 0.76 & 3.51 \\
\hline MX-225 & 151.58 & 82 & 0.7 & 17 & -26.58 & 175 & 1328 & 15 & 20 & 10 & 45 & 5703 & 6 & 28 & 3 & 1133 & 565 & 0.73 & 4.96 \\
\hline MX-224 & 151.54 & 62 & 1.4 & 37 & -26.42 & 175 & 2447 & 25 & 35 & 15 & 48 & $8 \quad 10764$ & 8 & 34 & 10 & 2205 & 466 & 0.69 & 4.06 \\
\hline MX-223 & 151.47 & 88 & 0.4 & 11 & -26.49 & 211 & 699 & 58 & 15 & 9 & 30 & 5676 & 3 & 23 & 3 & 592 & 650 & 0.72 & 7.91 \\
\hline MX-222 & 151.41 & 61 & 1.8 & 37 & -26.54 & 156 & 2497 & 18 & 36 & 14 & 46 & 8839 & 13 & 36 & 10 & 2212 & 432 & 0.72 & 2.83 \\
\hline MX-221 & 151.33 & 83 & 0.6 & 17 & -26.60 & 215 & 791 & 12 & 11 & 7 & 35 & 2737 & 4 & 21 & 2 & 574 & 548 & 0.74 & 4.76 \\
\hline MX-220 & 151.26 & 52 & 2.1 & 46 & -26.39 & 179 & 2756 & 69 & 55 & 22 & 39 & 911377 & 9 & 32 & 14 & 2789 & 391 & 0.60 & 3.66 \\
\hline MX-219 & 151.17 & 85 & 0.4 & 15 & -26.54 & 170 & 894 & 13 & 12 & 5 & 34 & $4 \quad 2890$ & 3 & 23 & 1 & 665 & 549 & 0.82 & 7.10 \\
\hline MX-218 & 151.13 & 71 & 1.0 & 27 & -26.41 & 148 & 2183 & 14 & 36 & 15 & 51 & 8010 & 10 & 40 & 6 & 1886 & 544 & 0.73 & 3.92 \\
\hline MX-217 & 151.07 & 87 & 0.4 & 12 & -26.54 & 130 & 482 & 5 & 21 & 4 & 23 & 1444 & 3 & 17 & 1 & 394 & 420 & 0.80 & 5.81 \\
\hline MX-216 & 151.01 & 65 & 1.5 & 33 & -26.51 & 152 & 2232 & 17 & 35 & 18 & 46 & 8515 & 13 & 32 & 9 & 1965 & 499 & 0.65 & 2.56 \\
\hline MX-214 & 150.94 & 62 & 1.7 & 36 & -26.55 & 138 & 2431 & 7 & 46 & 16 & 57 & 710156 & 10 & 37 & 9 & 1972 & 429 & 0.70 & 3.58 \\
\hline MX-212 & 150.84 & 63 & 1.7 & 36 & -26.45 & 131 & 2051 & 8 & 48 & 12 & 49 & $9 \quad 9138$ & 8 & 32 & 8 & 1698 & 431 & 0.73 & 4.31 \\
\hline MX-211 & 150.80 & 84 & 0.5 & 16 & -26.73 & 120 & 707 & 10 & 18 & 4 & 42 & 3467 & 4 & 23 & 1 & 720 & 521 & 0.84 & 6.64 \\
\hline MX-210 & 150.74 & 73 & 1.2 & 25 & -26.65 & 110 & 1123 & 9 & 24 & 10 & 59 & 9925 & 12 & 35 & 4 & 1130 & 448 & 0.78 & 2.90 \\
\hline MX-209 & 150.65 & 86 & 0.3 & 13 & -26.66 & 117 & 484 & 8 & 14 & 5 & 41 & 3332 & 3 & 15 & 1 & 536 & 527 & 0.74 & 4.29 \\
\hline MX-208 & 150.45 & 69 & 1.3 & 30 & -26.81 & 113 & 752 & 4 & 11 & 7 & 56 & 5055 & 7 & 14 & 1 & 802 & 542 & 0.65 & 1.88 \\
\hline MX-207 & 150.26 & 82 & 0.6 & 18 & -26.77 & 139 & 1304 & 6 & 30 & 11 & 64 & 410944 & 14 & 38 & 5 & 1352 & 433 & 0.77 & 2.66 \\
\hline MX-206 & 150.10 & 78 & 0.8 & 21 & -26.70 & 111 & 1057 & 8 & 12 & 9 & 59 & 6112 & 8 & 16 & 3 & 965 & 538 & 0.64 & 2.01 \\
\hline MX-205 & 149.90 & 58 & 1.5 & 41 & -26.63 & 227 & 1722 & 9 & 23 & 24 & 38 & 811233 & 13 & 11 & 12 & 1659 & 492 & 0.31 & 0.86 \\
\hline MX-204 & 149.60 & 60 & 1.7 & 38 & -26.86 & 133 & 1707 & 10 & 97 & 22 & 34 & $4 \quad 5824$ & 14 & 11 & 10 & 1493 & 455 & 0.32 & 0.76 \\
\hline MX-182 & 144.47 & 71 & 1.2 & 28 & - & 158 & 2587 & 21 & 40 & 16 & 46 & 7294 & 18 & 31 & 8 & 2963 & 603 & 0.66 & 1.79 \\
\hline MX-181 & 144.17 & 72 & 1.4 & 27 & - & 195 & 2316 & 19 & 32 & 18 & 47 & 7467 & 16 & 33 & 8 & 2848 & 564 & 0.65 & 2.03 \\
\hline MX-180 & 143.95 & 73 & 1.2 & 26 & - & 204 & 2351 & 19 & 30 & 20 & 44 & 7698 & 15 & 19 & 7 & 3052 & 683 & 0.49 & 1.28 \\
\hline MX-179 & 143.71 & 71 & 1.7 & 27 & - & 202 & 2475 & 22 & 32 & 20 & 37 & 5682 & 17 & 27 & 9 & 2480 & 723 & 0.57 & 1.64 \\
\hline MX-178 & 143.44 & 61 & 2.1 & 37 & - & 181 & 3636 & 26 & 433 & 27 & 33 & 7564 & 23 & 29 & 15 & 3701 & 503 & 0.51 & 1.23 \\
\hline MX-177 & 143.14 & 54 & 2.4 & 43 & - & 181 & 3430 & 21 & 58 & 25 & 29 & 8299 & 18 & 20 & 17 & 3493 & 449 & 0.45 & 1.14 \\
\hline MX-176 & 142.84 & 75 & 1.1 & 24 & - & 186 & 2637 & 23 & 21 & 15 & 38 & 5640 & 18 & 24 & 7 & 2752 & 709 & 0.62 & 1.38 \\
\hline
\end{tabular}

Table 8-2. Indidura Formation, sample stratigraphic assignment, stable isotopes and elemental concentrations (continued). 


\begin{tabular}{|c|c|c|c|c|c|c|c|c|c|c|c|c|c|c|c|c|c|c|c|}
\hline Sample \# & $\begin{array}{c}\text { Distance } \\
\text { Base }\end{array}$ & $\begin{array}{c}\text { Total } \\
\text { Carbonate } \\
\text { wt } \%\end{array}$ & $\begin{array}{c}\text { Total } \\
\text { Organic } \\
\text { Carbon } \\
\text { wt } \%\end{array}$ & $\begin{array}{c}\text { Non } \\
\text { Carbonate } \\
\text { Fraction } \\
\text { wt } \%\end{array}$ & $\delta^{13} \mathbf{C}_{\text {org }}$ & $\begin{array}{c}\mathrm{Na} \\
\text { (ppm) }\end{array}$ & $\begin{array}{c}\mathbf{K} \\
(\mathbf{p p m})\end{array}$ & $\begin{array}{c}\text { Mo } \\
\text { (ppm) }\end{array}$ & $\begin{array}{c}\mathbf{Z n} \\
(\mathrm{ppm})\end{array}$ & $\begin{array}{c}\mathrm{Ni} \\
(\mathrm{ppm})\end{array}$ & $\begin{array}{c}\text { Mn } \\
(\mathbf{p p m})\end{array}$ & $\begin{array}{c}\mathrm{Fe} \\
(\mathbf{p p m})\end{array}$ & $\begin{array}{c}\mathbf{C r} \\
(\mathbf{p p m})\end{array}$ & $\begin{array}{c}\mathrm{V} \\
(\mathrm{ppm})\end{array}$ & $\begin{array}{c}\mathrm{Cu} \\
(\mathrm{ppm})\end{array}$ & $\begin{array}{c}\text { Al } \\
\text { (ppm) }\end{array}$ & $\begin{array}{c}\mathrm{Sr} \\
\text { (ppm) }\end{array}$ & $\mathrm{V} /(\mathbf{V}+\mathrm{Ni})$ & $\mathrm{V} / \mathbf{C r}$ \\
\hline MX-175 & 142.46 & 81 & 0.7 & 18 & - & 171 & 1528 & 21 & 24 & 12 & $\overline{44}$ & 7528 & 12 & 14 & 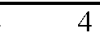 & 2400 & 614 & 0.53 & 1.12 \\
\hline MX-174 & 142.13 & 72 & 1.6 & 27 & - & 159 & 2477 & 21 & 34 & 21 & 34 & 6429 & 28 & 21 & 9 & 2243 & 653 & 0.50 & 0.76 \\
\hline MX-173 & 141.84 & 58 & 2.3 & 40 & - & - & - & 14 & 38 & 25 & 30 & 8012 & 18 & 20 & 14 & 3147 & 494 & 0.44 & 1.11 \\
\hline MX-172 & 141.63 & 70 & 1.4 & 29 & - & 182 & 2776 & 18 & 205 & 21 & 36 & 6713 & 18 & 18 & 10 & 2932 & 647 & 0.46 & 0.98 \\
\hline MX-171 & 141.12 & 85 & 0.6 & 14 & - & 124 & 870 & 16 & 18 & 10 & 62 & 9596 & 10 & 11 & 2 & 989 & 539 & 0.52 & 1.06 \\
\hline MX-170 & 140.77 & 68 & 1.5 & 31 & - & 164 & 2578 & 16 & 46 & 22 & 38 & 7353 & 17 & 18 & 11 & 2539 & 638 & 0.46 & 1.08 \\
\hline MX-169 & 140.52 & 55 & 2.2 & 43 & - & 208 & 3028 & 25 & 93 & 26 & 42 & 7805 & 17 & 17 & 14 & 2934 & 507 & 0.40 & 1.01 \\
\hline MX-168 & 140.37 & 67 & 1.2 & 32 & - & 192 & 2498 & 23 & 44 & 21 & 41 & 6307 & 19 & 15 & 9 & 2469 & 682 & 0.41 & 0.77 \\
\hline MX-167 & 140.29 & 85 & 0.5 & 14 & - & 145 & 877 & 15 & 9 & 14 & 48 & 4542 & 16 & 13 & 2 & 724 & 579 & 0.47 & 0.79 \\
\hline MX-130 & 106.77 & 58 & 1.0 & 41 & -26.76 & 141 & 2150 & 3 & 43 & 17 & 37 & 5969 & 14 & 18 & 12 & 2617 & 433 & 0.53 & 1.34 \\
\hline MX-129 & 106.17 & 63 & 1.0 & 36 & -26.73 & 160 & 2237 & 4 & 56 & 27 & 51 & 7521 & 17 & 16 & 10 & 2708 & 463 & 0.38 & 0.97 \\
\hline MX-128 & 105.81 & 75 & 0.6 & 24 & -26.69 & 144 & 1299 & 2 & 27 & 18 & 73 & 311801 & 13 & 13 & 6 & 1991 & 528 & 0.43 & 1.03 \\
\hline MX-127 & 105.19 & 76 & 0.5 & 23 & -26.63 & 145 & 1368 & & 21 & 17 & 73 & 310470 & 11 & 12 & 5 & 1577 & 531 & 0.41 & 1.09 \\
\hline MX-126 & 101.64 & 81 & 0.4 & 18 & -26.85 & 106 & 885 & 3 & 12 & 20 & 90 & 912833 & 13 & 10 & 3 & 898 & 608 & 0.33 & 0.76 \\
\hline MX-125 & 101.02 & 46 & 1.6 & 52 & -26.56 & 174 & 2851 & 3 & 58 & 31 & 37 & $7 \quad 8240$ & 23 & 14 & 14 & 2749 & 416 & 0.30 & 0.61 \\
\hline MX-124 & 100.57 & 54 & 1.0 & 45 & -26.66 & 152 & 2186 & 17 & 36 & 41 & 38 & 6682 & 26 & 12 & 11 & 2218 & 447 & 0.22 & 0.45 \\
\hline MX-123 & 100.02 & 56 & 1.1 & 43 & -26.64 & 163 & 2304 & 15 & 27 & 29 & 42 & 6269 & 21 & 15 & 10 & 2306 & 467 & 0.33 & 0.71 \\
\hline MX-122 & 99.76 & 74 & 0.5 & 26 & -26.69 & 155 & 1253 & 14 & 10 & 24 & 59 & 6049 & 11 & 10 & 5 & 1056 & 537 & 0.29 & 0.91 \\
\hline MX-121 & 99.23 & 56 & 1.5 & 43 & -26.58 & 150 & 2242 & 19 & 15 & 33 & 49 & 6014 & 26 & 19 & 9 & 2035 & 418 & 0.36 & 0.71 \\
\hline MX-120B & 98.73 & 55 & 0.9 & 44 & -26.48 & 212 & 2412 & 19 & 32 & 34 & 39 & 7557 & 24 & 16 & 10 & 2692 & 450 & 0.32 & 0.66 \\
\hline MX-120A & 98.73 & 75 & 0.4 & 25 & -26.51 & 132 & 1033 & 9 & 25 & 22 & 58 & 5442 & 13 & 12 & 5 & 892 & 529 & 0.35 & 0.91 \\
\hline MX-119 & 98.30 & 50 & 1.3 & 48 & -26.56 & 196 & 2502 & 15 & 32 & 44 & 38 & 7276 & 32 & 14 & 12 & 2908 & 442 & 0.24 & 0.44 \\
\hline MX-118 & 97.93 & 76 & 0.3 & 24 & -26.65 & 166 & 1074 & 8 & 11 & 28 & 54 & 3839 & 19 & 13 & 3 & 1080 & 557 & 0.31 & 0.65 \\
\hline MX-117 & 97.56 & 48 & 1.1 & 50 & -26.46 & 157 & 2620 & 7 & 42 & 31 & 32 & 6881 & 23 & 17 & 12 & 2739 & 376 & 0.36 & 0.74 \\
\hline MX-116 & 97.32 & 71 & 0.6 & 29 & -26.59 & 150 & 1393 & 11 & 17 & 39 & 60 & 5278 & 44 & 16 & 5 & 1229 & 531 & 0.29 & 0.36 \\
\hline MX-115 & 96.80 & 50 & 1.0 & 49 & -26.57 & 192 & 2060 & 7 & 39 & 34 & 31 & 6314 & 21 & 17 & 10 & 2491 & 403 & 0.34 & 0.81 \\
\hline MX-114 & 96.55 & 72 & 0.5 & 27 & -26.66 & 130 & 1160 & 13 & 9 & 52 & 59 & 5078 & 46 & 14 & 5 & 1215 & 534 & 0.21 & 0.30 \\
\hline MX-063 & 74.91 & 74 & 1.0 & 25 & - & 228 & 2511 & 11 & 19 & 5 & 42 & 9114 & 10 & 22 & 5 & 2499 & 542 & 0.80 & 2.24 \\
\hline MX-062 & 74.31 & 65 & 1.3 & 33 & - & 268 & 3735 & 19 & 30 & 8 & 33 & 6146 & 11 & 21 & 11 & 3034 & 475 & 0.73 & 1.95 \\
\hline MX-061 & 73.88 & 65 & 1.4 & 34 & - & 231 & 2744 & 12 & 35 & 9 & 33 & 5528 & 9 & 18 & 9 & 2602 & 468 & 0.67 & 1.95 \\
\hline MX-051 & 68.81 & 68 & 1.2 & 31 & -26.00 & 175 & 2774 & - & 35 & 11 & 36 & 6303 & 5 & 15 & 12 & 2071 & 624 & 0.57 & 2.93 \\
\hline MX-050 & 65.59 & 81 & 0.4 & 18 & -25.83 & 209 & 2959 & 19 & 13 & 9 & 43 & 310525 & 4 & 40 & 6 & 2282 & 575 & 0.82 & 9.89 \\
\hline MX-049 & 65.19 & 60 & 0.5 & 39 & -25.78 & 214 & 2415 & 206 & 39 & 23 & 38 & 811316 & 4 & 35 & 15 & 2175 & 484 & 0.60 & 9.80 \\
\hline
\end{tabular}

Table 8-2. Indidura Formation, sample stratigraphic assignment, stable isotopes and elemental concentrations (continued). 


\begin{tabular}{|c|c|c|c|c|c|c|c|c|c|c|c|c|c|c|c|c|c|c|c|}
\hline Sample \# & $\begin{array}{c}\text { Distance } \\
\text { Base }\end{array}$ & $\begin{array}{c}\text { Total } \\
\text { Carbonate } \\
\text { wt } \%\end{array}$ & $\begin{array}{c}\text { Total } \\
\text { Organic } \\
\text { Carbon } \\
\mathbf{w t} \%\end{array}$ & $\begin{array}{c}\text { Non } \\
\text { Carbonate } \\
\text { Fraction } \\
\text { wt\% }\end{array}$ & $\delta^{13} \mathrm{C}_{\text {org }}$ & $\begin{array}{c}\mathrm{Na} \\
(\mathrm{ppm})\end{array}$ & $\begin{array}{c}\mathbf{K} \\
\text { (ppm) }\end{array}$ & $\begin{array}{c}\text { Mo } \\
\text { (ppm) }\end{array}$ & $\begin{array}{c}\text { Zn } \\
(\mathbf{p p m})\end{array}$ & $\begin{array}{c}\mathrm{Ni} \\
(\mathrm{ppm})\end{array}$ & $\begin{array}{c}\text { Mn } \\
(\mathrm{ppm})\end{array}$ & $\begin{array}{c}\mathbf{F e} \\
(\mathbf{p p m})\end{array}$ & $\begin{array}{c}\mathbf{C r} \\
(\mathrm{ppm})\end{array}$ & $\begin{array}{c}\mathbf{V} \\
(\mathrm{ppm})\end{array}$ & $\begin{array}{c}\mathrm{Cu} \\
(\mathrm{ppm})\end{array}$ & $\begin{array}{c}\text { Al } \\
\text { (ppm) }\end{array}$ & $\begin{array}{c}\text { Sr } \\
\text { (ppm) }\end{array}$ & $\mathrm{V} /(\mathrm{V}+\mathrm{Ni})$ & $\mathrm{V} / \mathrm{Cr}$ \\
\hline MX-048 & 64.59 & 75 & 0.1 & 25 & - & 217 & 2367 & 108 & 35 & 14 & 33 & 6387 & 6 & 52 & 9 & 2042 & 528 & 0.79 & 8.75 \\
\hline MX-047 & 64.13 & 79 & 0.4 & 20 & -26.34 & 186 & 1521 & 6 & 9 & 4 & 46 & 4465 & 6 & 23 & 4 & 1039 & 534 & 0.86 & 3.93 \\
\hline MX-046 & 64.03 & 59 & 0.6 & 40 & -26.38 & 182 & 2595 & 13 & 32 & 12 & 41 & 7028 & 6 & 37 & 11 & 2169 & 515 & 0.75 & 6.35 \\
\hline MX-045 & 63.95 & 81 & 0.3 & 18 & -26.23 & 172 & 1058 & 10 & 13 & 5 & 43 & 17463 & 3 & 31 & 4 & 671 & 559 & 0.86 & 11.96 \\
\hline MX-044 & 63.10 & 57 & 0.7 & 42 & -26.24 & 170 & 1748 & 7 & 31 & 9 & 42 & 6085 & 5 & 34 & 12 & 1459 & 480 & 0.79 & 7.33 \\
\hline MX-043 & 62.67 & 92 & 0.1 & 8 & -25.18 & 147 & 1025 & 7 & 4 & 2 & 9 & 1152 & 2 & 4 & 1 & 1416 & 206 & 0.63 & 2.00 \\
\hline MX-042 & 62.00 & 54 & 1.3 & 45 & -24.97 & 233 & 4116 & 5 & 37 & 12 & 34 & 8387 & 9 & 15 & 12 & 3700 & 467 & 0.56 & 1.64 \\
\hline MX-041 & 61.49 & 68 & 0.8 & 31 & -26.57 & 197 & 2190 & 6 & 21 & 8 & 53 & 6350 & 6 & 13 & 11 & 1773 & 488 & 0.63 & 2.13 \\
\hline MX-040 & 60.48 & 66 & 1.1 & 33 & -26.66 & 200 & 2253 & 6 & 23 & 7 & 48 & 6425 & 7 & 14 & 9 & 1948 & 483 & 0.66 & 1.95 \\
\hline MX-039 & 60.12 & 87 & 0.2 & 12 & -24.82 & 150 & 1086 & 6 & 7 & 3 & 15 & 1482 & 4 & 6 & 1 & 1627 & 217 & 0.70 & 1.68 \\
\hline MX-038 & 59.90 & 71 & 0.7 & 29 & -26.40 & 238 & 2168 & 4 & 19 & 6 & 61 & 7720 & 8 & 20 & 8 & 2019 & 514 & 0.76 & 2.48 \\
\hline MX-037 & 59.55 & 60 & 0.5 & 40 & -26.29 & 223 & 2499 & 10 & 43 & 16 & 54 & 8745 & 9 & 18 & 16 & 2504 & 516 & 0.53 & 2.02 \\
\hline MX-036 & 57.52 & 82 & 0.2 & 18 & -26.54 & 153 & 1309 & - & 40 & 14 & 21 & 7249 & 4 & 8 & 6 & 1882 & 287 & 0.38 & 1.92 \\
\hline MX-035 & 56.37 & 60 & 0.4 & 40 & -26.09 & 202 & 2416 & - & 32 & 11 & 51 & 7980 & 7 & 12 & 12 & 2433 & 525 & 0.52 & 1.76 \\
\hline MX-034 & 54.49 & 72 & 0.2 & 28 & -25.73 & 163 & 2164 & 2 & 31 & 12 & 68 & 5988 & 5 & 8 & 11 & 2327 & 383 & 0.40 & 1.53 \\
\hline MX-032B & 53.56 & 68 & 0.5 & 31 & -26.01 & 177 & 2622 & 3 & 27 & 9 & 48 & 7620 & 7 & 13 & 9 & 2723 & 499 & 0.59 & 1.76 \\
\hline MX-032A & 53.30 & 69 & 0.6 & 30 & -26.24 & 171 & 2030 & 2 & 29 & 8 & 62 & 10655 & 7 & 13 & 10 & 2276 & 512 & 0.63 & 1.97 \\
\hline Low & & 92 & & 70 & -24.8 & 106 & 4882 & 0 & 3 & 2 & $\overline{9}$ & 91152 & 2 & 4 & 0 & 394 & 206 & 0.21 & 0.30 \\
\hline High & & 27 & 0.1 & 8 & -27.2 & 275 & 5164 & 370 & 433 & 52 & 90 & 23028 & 58 & 52 & 18 & 6578 & 748 & 0.86 & 11.96 \\
\hline Average & & 67 & 1.2 & 32 & -26.4 & 171 & 1979 & 29 & 33 & 17 & 43 & 6899 & 13 & 23 & 7 & 2094 & 519 & 0.57 & 2.47 \\
\hline$\overline{\text { L Shale }}$ & & - & - & - & - & 189 & 303500 & $\overline{0}$ & $\overline{0}$ & 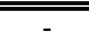 & $\overline{0}$ & $\begin{array}{l}0 \quad 15 \\
\end{array}$ & $\overline{4}$ & 39 & - & 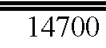 & 0 & - & 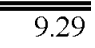 \\
\hline H Shale & & - & - & - & - & 24800 & 83580 & 603 & 3780 & - & 3781 & 99790 & 460 & 6260 & - & 133900 & 1680 & - & 13.61 \\
\hline $\operatorname{Avg} C / T S$ & hale & - & 8.1 & - & - & 10328 & 15275 & 316 & 2056 & 267 & 557 & 738327 & 179 & 1066 & 194 & 53978 & 258 & 0.80 & 5.96 \\
\hline Avg Shale & & - & 0.2 & - & - & 9600 & 26600 & 2.6 & 95 & 68 & 850 & 47200 & 90 & 130 & 45 & 80000 & 300 & 0.66 & 1.44 \\
\hline
\end{tabular}

Table 8- 2. Indidura Formation, sample stratigraphic assignment, stable isotopes and elemental concentrations (Continued). Average C/T Shale from Brumsack (2006); average shale from Wedepohl (1971, 1991); Low and High black shale from (Quinby-Hunt et al. 1989). 
components may be the reason for them being overlooked and led to other interpretations. Indeed, previous research in the Sierra Madre Oriental (Kelly, 1936; Imlay, 1936, Caron and Tardy 1971, Longoria, 1999) interpreted the fine laminae formed by the microspheres as broken fragments of foraminifera, calcareous dinoflagelates and calcispheres. Nevertheless, close observation of the ultrastructure reveal a 3 to $5 \mu \mathrm{m}$ thick rim of microcrystalline calcite that is not comparable to a "test", of any of the microfossil groups mentioned (Duque-Botero and Maurrasse, 2005).

Microspheroids can occur as scattered spheroids, or aggregates of microspheroid strings (Figure 8- 5 G,F,J,L), and are composed of multiple crystals of calcite. Such structures are similar to the internal structures revealed by strings of attached cells described by Golubic and Campbell (1981), and to cyanobacterial structures (Kazmierczak and Krumbein, 1983; Tribovillard, 1998; Tribovillard, et al., 2000; Giralt et al. 2001, Kazmierczak and Altermann, 2002; Braissant et al. 2003; Brehm et al. 2004). Further evidence is found inside some of the microspheroids (Figure 8- 5 A,B,D,I) that show original micro-calcite crystals $(<2 \mu \mathrm{m})$, while others have been recrystallized (Figure 8- 5 C,E). In addition, EDS analysis (Duque-Botero and Maurrasse, 2005) of the microcrystalline rim shows an excess of Carbon, which is attributed to the organic-rich extracellular polymeric secretion (EPS) rich membranes that act as a nucleation center for the precipitation of carbonate minerals. This feature is also observed under the petrographic microscope as a dark envelope covering the microspheroids (Figure 8-4). SEM semi-quantitative EDS analyses of samples from the Indidura Formation supports the petrographic observation indicating high clay content in sediments where the matrixis 
composed mainly of microcrystalline calcite and minor amounts of framboidal pyrite (Duque-Botero and Maurrasse, 2005).

\subsubsection{The OAE II at Parras de la Fuente}

Isotopic changes related to the Cenomanian/Turonian boundary event or OAE2 are usually explained to be a consequence of a global change that affected the carbon budget,

and permitted widespread accumulation of organic matter and concurrent increase of ${ }^{12} \mathrm{C}$ sequestered by marine OM (Jenkyns, 1980; Arthur et al. 1987). Such changes produced the typical isotopic records of the OAE2, and are marked by the inception of a positive $\delta^{13} \mathrm{C}$ excursion. The timing of the event itself appears to be diachronous because both the anoxia peak and isotopic excursion have different expressions and timing from section to section (Tsikos et al, 2004). Carbon sequestration and enrichment process continued throughout the time interval of the event, which ended with the return to pre- OAE2 isotopic values (Snow et al., 2005). The duration and timing of OAE2 at the Global Boundary Stratotype Section Point (GSSP) for the base of the Turonian stage, at Pueblo Viejo, Colorado (Sageman et al., 2006), shows that the time from the onset to the conclusion of the OAE2 is about 563 to $601 \mathrm{k} . \mathrm{y}$. (5.5. m thick) to about 847 to $885 \mathrm{k} . \mathrm{y}$. ( $7.5 \mathrm{~m}$ thick). The duration observed in the Indidura Formation is similar to that of the GSSP, but with a difference in the timing of the event. In this Mexican section the positive isotopic excursion has its maximum $-24.7 \%$, within the CC11 Nannofossil Zone. Although the Parras section is relatively close to the Pueblo Viejo GSSP, perhaps the observed difference in timing may be attributed to better biochronology, and sampling resolution, which is greater at the GSSP section. Nonetheless, the record in the Parras de 
la Fuente section not only shows the rapid onset of the positive excursion of about $2 \%$, but it also shows subsequent return to pre OAE2 conditions, as well a second minor excursion of about $1.5 \%$ that correlates with the anomaly described by Leckie et al. (2002).

Comparison of samples from the Indidura Formation with the average trace metals in shale shows enrichment in (V, Mo, $\mathrm{Ni}, \mathrm{Cu}, \mathrm{Cr})$, but lower values for $\mathrm{Mn}$ and Fe. Elevated values like those observed in the samples studied from the Parras section are interpreted as expressing a depositional environment with strong reducing conditions. The very low contents of Fe and Mn, together with high values of V (Table 8.2) are suggestive of an environment associated with low ph and Eh conditions (Quinby-Hunt and Wilde, 1994). The $\mathrm{V} /(\mathrm{V}+\mathrm{Ni})>0.5$ and $\mathrm{V} / \mathrm{Cr}>2.2$ indices of Hatch and Leventhal (1992) further concur that most of the sedimentary rocks of the Indidura Formation at Parras de la Fuente were deposited under low-oxygen conditions. In general enriched and depleted zones in Mo, $\mathrm{V}$, as well as $\mathrm{Cr}$, and high and low for oxygen indices $(\mathrm{V} /(\mathrm{V}+\mathrm{Ni}) ; \mathrm{V} / \mathrm{Cr})$ corroborate the field and petrographic observations that show intervals of the stratigraphic section where macro and microfossils were absent because they were unable to either live on the bottom or near the water surface interface for long periods of time due to severe oxygen depletion of the full water column in the Parras Basin. The elevated trace metal values and the organic mater content, together with the abundance of microspheroids points out to a depositional setting where intense primary productivity dominated by cyanobacteria and bacteria as depicted from the petrographic, SEM and biomarker analysis, depleted the 
water oxygen levels, and promoted the expansion of anoxic waters throughout the water column.

When comparing the maximum value of the trace metals and $\delta^{13}$ Corg, Snow et al. (2005), surmised that the proximity of the Pueblo Viejo section to the Caribbean Plateau as a reason for the diachronous occurrence of the OAE2 between the Cretaceous Western Interior Seaway and the Tethyan sections. This idea is supported by the major perturbations that are shown by radiolarians and calcareous nannofossils (Bralower, 1988; Premoli Silva et al. 1999) as well as deep-dwelling foraminifera. Perturbations in these microfossil records are interpreted to be related major shifts in temperatures, in the structure of the water column and resulting accelerated oxygen depletion (Leckie, 1985, 1989). We propose that the onset of the Large Igneous Provinces (LIP) volcanism (Larson, 1991; Caldeira and Rampino, 1991) and specially the adjacent Caribbean Plateau (Sinton and Duncan, 1997; Kerr, 1998) that is coeval with the event observed may have had a profound effect in the sedimentation history of the Mesozoic Mexican platform. The expansion of archaea and other types of bacteria was also proposed by Kuypers et al. (2004), and Dumitrescu and Brassell (2005) to explain the abundance of specific type of biomarkers. Although specific biomarkers were not found in our samples, the presence of low molecular n-alkanes is suggestive of such presence (Peters et al., 2005). However, the different proxies used in the present work concur with the prevalence of prokaryotic organisms throughout the deposition of the Indidura Formation of the Parras Basin. Competitive exclusion (Duque-Botero and Maurrasse, 2005), and oxygen depletion led to conditions unfavorable to other organisms throughout the water 
column, except at intermittent intervals when planktonic foraminifera and radiolarians were able to thrive at the surface.

\subsection{Summary}

Petrographic, SEM imaging, sediments of the Indidura Formation show the record of long lasting anoxic conditions of an epicontinental sea from the uppermost Cenomanian up to the Middle Turonian. This time interval was associated with the deposition of finely laminated sediments composed of calcareous cyanobacterial microspheroids.

The stable isotope of C-org in the Sierra de Parras shows that maximum positive excursion of the OAE2 excursion developed at a slightly younger level than observed at the GSSP. The discrepancy is probably related either to sampling resolution or to local conditions that generated different circulation patterns on the Mexican platform. Nevertheless, the $2 \%$ positive isotopic excursion is of the same magnitude as that of the OAE2 found in sections elsewhere. Trace metal enrichments follows the same trend as that of the isotopic excursions, suggesting similar origin for the two events.

The sedimentary record of the Indidura Formation thus shows the accumulation of organic-rich deposits on an epicontinental sea, together with an abundance of calcareous microspheroids of cyanobacterial origin during a time dominated by severe oxygen depletion in the water column. 


\subsection{Acknowledgments}

This work was partially funded by the Dissertation Year Fellowship of Florida

International University, awarded to Fabian Duque-Botero; the Glenn A. Goodfriend Memorial funds, and other private funding sources. Many thanks to, Barbara Maloney at the Florida International University Center for Analytical Electron Microscopy (FCAEM) for her assistance with SEM images, and Diane Pirie for her graciousness and patience in keeping the CR-412 Carbon Analyzer and the ICP-AES in working condition. The authors of this paper are deeply grateful Mr. Ignacio Chacon and to the people of Parras who collaborated during the field excursions. This is contribution No. 06-01 of the Sedimentology and Stratigraphy group at FIU. 


\subsection{References}

Arp, G., Reimer, A., and Reitner, J., 2001, Photosynthesis-Induced Biofilm Calcification and Calcium Concentrations in Phanerozoic Oceans: Science, v. 292, p. 17011704.

Arthur, M.A., Schlanger, S.O., and Jenkyns, H.C., 1987, The Cenomanian- Turonian Oceanic Anoxic Event, II. Palaeoceanographic controls on organic-matter production and preservation, in Brooks, J. and Fleet, A.J., eds., Marine petroleum source rocks: Oxford, Blackwell Scientific, p. 401-420.

Braissant, O., Cailleau, G., Dupraz, C., and Verrecchia, E.P., 2003, Bacterially Induced Mineralization of Calcium Carbonate in Terrestrial Environments: The Role of Exopolysaccharides and Amino Acids: Journal of Sedimentary Research, v. 73, p. 485-490.

Bralower, T.J., 1988, Calcareous nannofossil biostratigraphy and assemblages of the Cenomanian-Turonian boundary interval; implications for the origin and timing of oceanic anoxia: Paleoceanography, v. 3, p. 275-316.

Brehm, U., Palinska, K.A., and Krumbein, W.E., 2004, Laboratory cultures of calcifying biomicrospheres generate ooids - A contribution to the origin of oolites: Carnets de Géologie /Notebooks on Geology, v. Letter 2004/03 (CG2004_L03) http://paleopolis.rediris.es/cg/CG2004_L03/.

Brumsack, H.J., 2006, The trace metal content of recent organic carbon-rich sediments: Implications for Cretaceous black shale formation: Palaeogeography, Palaeoclimatology, Palaeoecology, v. 232, p. 344-361.

Burnett, J.A., Gallagher, L.T., and Hampton, M.J., 1999, Upper Cretaceous, in Bown P.R., ed., Calcareous nannofossil biostratigraphy: Dordrecht, Kluwer Academic Publishers, p. 132-199.

Caldeira, K. and Rampino, M.R., 1991, The Mid-Cretaceous superplume, carbon dioxide, and global warming: Geophysical Research Letters, p. 987-990.

Caron, M. and Tardy, M., 1971, Precisions sur l'age cretace superieur de la formation Indidura des abords de la Laguna de Mayran, Coahuila, Mexique. The upper Cretaceous age of Indidura Formation of the Laguna de Mayran shore, Coahuila, Mexico: Bulletin de la Societe Geologique de France, v. 7, p. 361-363.

Didyck, B.M., Somoneit, B., Brassel, S.C., and Eglinton, G., 1978, Organic geochemical indicators of paleoenvironmental conditions of sedimentation: Nature, v. 272, p. 216-222. 
Dumitrescu, M. and Brassell, S.C., 2005, Biogeochemical assessment of sources of organic matter and paleoproductivity during the early Aptian Oceanic Anoxic Event at Shatsky Rise, ODP Leg 198: Organic Geochemistry, v. 36, p. 1002-1022.

Duque-Botero, F. and Maurrasse, F.J.-M.R., 2005, Cyanobacterial productivity, variations in the organic matter and facies of the Indidura Formation (Cenomanian-Turonian), Northeastern Mexico: Journal of Iberian Geology, v. 31, p. $87-100$.

Ehrlich, H.L., 1998, Geomicrobiology: its significance for geology: Earth-Science Reviews, v. 45, p. 45-60.

Erba, E., 2004, Calcareous nannofossils and Mesozoic oceanic anoxic events: Marine Micropaleontology, v. 52, p. 85-106.

Forchheimer, S., 1972, Scanning electron microscope study of Cretaceous coccoliths: Lund, Lunds University, PhD Dissertation, 141p.

Gale, A.S., Hardenbol, J., Hathway, B., James Kennedy, W., Young, J.R., and Phansalkar, V., 2002, Global correlation of Cenomanian (Upper Cretaceous) sequences: Evidence for Milankovitch control on sea level: Geology, v. 30, p. 291-294.

Giralt, S., Julia, R., and Klerkx, J., 2001, Microbial Biscuits of Vaterite in Lake Issyk-Kul (Republic of Kyrgyzstan): Journal of Sedimentary Research, v. 71, p. 430-435.

Goddard, E.N., Overbeck, R.M., Rove, O.N., Singewald, J.T., Jr., and Trask, P.D., 1948, Rock Color Chart: Washington, D. C, National Research Council, p. 6.

Golubic, S. and Campbell, S.E., 1981, Biogenically formed aragonite concretions in marine Rivularia, in Monty, C., ed., Phanerozoic stromatolites; case histories: Berlin, Federal Republic of Germany (DEU), Springer-Verlag, p. 209-229.

Hancock, J.M., 1993, Sea-level changes around the Cenomanian-Turonian boundary: Cretaceous Research, v. 14, p. 553-562.

Harries, P.J. and Kauffman, E.G., 1990, Patterns of survival and recovery following the Cenomanian-Turonian (Late Cretaceous) mass extinction in the Western Interior Basin, United States, in Kauffman, E.G. and Walliser, O.H., eds., Extinction events in earth history. Lecture Notes in Earth Sciences 30: Berlin, SpringerVerlag, p. 277-298.

Hatch, J.R. and Leventhal, J.S., 1992, Relationship between inferred redox potential of the depositional environment and geochemistry of the Upper Pennsylvanian (Missourian) Stark Shale Member of the Dennis Limestone, Wabaunsee County, Kansas, U.S.A: Chemical Geology, v. 99, p. 65-82. 
Imlay, R.W., 1936, Evolution of the Coahuila Peninsula, Mexico; Part 4, Geology of the western part of the Sierra de Parras: Geological Society of America Bulletin, v. 47, p. 1091-1152.

Jaffe, R., Mead, R., Hernandez, M.E., Peralba, M.C., and DiGuida, O.A., 2001, Origin and transport of sedimentary organic matter in two subtropical estuaries: a comparative, biomarker-based study: Organic Geochemistry, v. 32, p. 507-526.

Jenkyns, H.C., 1980, Cretaceous anoxic events; from continents to oceans: Journal of the Geological Society of London, v. 137, p. 171-188.

Jones, B. and Manning, D.A.C., 1994, Comparison of geochemical indices used for the interpretation of palaeoredox conditions in ancient mudstones: Chemical Geology, v. 111, p. 111-129.

Jones, T.S., 1938, Geology of Sierra de la Pena and paleontology of the Indidura Formation, Coahuila, Mexico: Geological Society of America Bulletin, v. 49, p. 69-149.

Kazmierczak, J. and Altermann, W., 2002, Neoarchean Biomineralization by Benthic Cyanobacteria: Science, v. 298, p. 2351.

Kazmierczak, J., Coleman, M.L., Gruszczynski, M., and Kempe, S., 1996, Cyanobacterial key to the genesis of micritic and peloidal limestones in ancient seas: Acta Palaeontologica Polonica, v. 41, p. 319-338.

Kazmierczak, J. and Krumbein, W.E., 1983, Identification of calcified coccoid cyanobacteria forming stromatoporoid stromatolites: Lethaia, v. 16, p. 207-213.

Kelly, W.A., 1936, Evolution of the Coahuila Peninsula, Mexico; Part 2, Geology of the mountains bordering the valleys of Acatita and Las Delicias: Geological Society of America Bulletin, v. 47, p. 1009-1038.

Kenig, F., Simons, D.J., and Anderson, K.B., 2001, Distribution and origin of ethylbranched alkanes in a Cenomanian transgressive shale of the Western Interior Seaway (USA): Organic Geochemistry, v. 32, p. 949-954.

Kerr, A.C., 1998, Oceanic plateau formation: a cause of mass extinction and black shale deposition around the Cenomanian-Turonian boundary?: Journal of the Geological Society, v. 155, p. 619-626.

Krumbein, W.E., 1974, On the Precipitation of Aragonite on the Surface of Marine Bacteria: Naturwissenschaften, v. 61, p. 167, 1974.

Kuypers, M.M.M., Blokker, P., Erbacher, J., Kinkel, H., Pancost, R.D., Schouten, S., and Sinninghe Damste, J.S., 2001, Massive Expansion of Marine Archaea During a Mid-Cretaceous Oceanic Anoxic Event: Science, v. 293, p. 92-95. 
Kuypers, M.M.M., Blokker, P., Hopmans, E.C., Kinkel, H., Pancost, R.D., Schouten, S., and Sinninghe Damste, J.S., 2002, Archaeal remains dominate marine organic matter from the early Albian oceanic anoxic event 1b: Palaeogeography, Palaeoclimatology, Palaeoecology, v. 185, p. 211-234.

Kuypers, M.M.M., van Breugel, Y., Schouten, S., Erba, E., and Sinninghe Damste, J.S., 2004, N (sub 2) -fixing cyanobacteria supplied nutrient $\mathrm{N}$ for Cretaceous oceanic anoxic events: Geology, v. 32, p. 853-856.

Lamolda, M.A., Gorostidi, A., Martinez, R., Lopez, G., and Peryt, D., 1997, Fossil occurrence in the Upper Cenomanian-Lower Turonian at Ganuza section, northern Spain: an approach to Cenomanian-Turonian boundary chronostratigraphy: Cretaceous Research, v. 18, p. 334-353.

Larson, R.L., 1991, Geological consequences of superplumes: Geology, v. 19, p. $963-$ 966.

Leckie, R.M., 1989, A paleoceanographic model for the early evolutionary history of planktonic foraminifera: Palaeogeography, Palaeoclimatology, Palaeoecology, v. 73, p. 107-138.

Leckie, R.M., 1985, Foraminifera of the Cenomanian-Turonian boundary interval, Greenhorn Formation, Rock Canyon Anticline, Pueblo, Colorado, in Pratt, L.M., Kauffman, E.G., and Zelt, F.B., eds., Fine-grained deposits and biofacies of the Cretaceous Western Interior Seaway; evidence of cyclic sedimentary processes: Tulsa, OK, Society of Economic Paleontologists and Mineralogists (SEPM), p. 139-150.

Leckie, R.M., Bralower, T.J., and Cashman, R., 2002, Oceanic anoxic events and plankton evolution: Biotic response to tectonic forcing during the midCretaceous: Paleoceanography, v. 17, p. 29.

Lewan, M.D., 1984, Factors controlling the proportionality of vanadium to nickel in crude oils: Geochimica et Cosmochimica Acta, v. 48, p. 2231-2238.

Longoria, J.F., Clowes, D.M., and Monreal, R., 1999, Type Mesozoic succession of northern Mexico; Canon La Casita, in Bartolini, C., Wilson, J.L., and Lawton, T.F., eds., Mesozoic sedimentary and tectonic history of north-central Mexico: Boulder, CO, Geological Society of America, p. 287-318.

Manivit, H., Perch-Nielsen, K., Prins, B., and Verbeek, J.W., 1977, Mid Cretaceous calcareous nannofossil biostratigraphy: Proceedings of the Koninklijke Nederlandse Akademie van Wetenschappen, v. 80, p. 169-181.

Merz-Preiss, M., 1992, The biology of carbonate precipitation by cyanobacteria: Facies, v. 26, p. 81-101. 
Morita, R.Y., 1980, Calcite precipitation by marine bacteria: Geomicrobiology Journal, v. 2, p. 63-82.

Paul, C.R.C., Lamolda, M.A., Mitchell, S.F., Vaziri, M.R., Goorostidi, A., and Marshall, J.D., 1999, The Cenomanian-Turonian boundary at Eastbourne (Sussex, UK): a proposed European reference section: Palaeogeography, Palaeoclimatology, Palaeoecology, v. 150, p. 83-121.

Peters, K.E., Walters, C.C., and Moldowan, J.M., 2005, The biomarker guide; II, Biomarkers and isotopes in petroleum systems and Earth history, Cambridge, UK, Cambridge University Press, p. 475-1155.

Pratt, B.R., 1984, Epiphyton and Renalcis; diagenetic microfossils from calcification of coccoid blue-green algae: Journal of Sedimentary Research, v. 54, p. 948-971.

Pratt, B.R., 2001, Calcification of cyanobacterial filaments: Girvanella and the origin of lower Paleozoic lime mud: Geology, v. 29, p. 763-766.

Premoli Silva, I., Erba, E., Salvini, G., Locatelli, C., and Verga, D., 1999, Biotic changes in Cretaceous oceanic anoxic events of the Tethys: The Journal of Foraminiferal Research, v. 29, p. 352-370.

Quinby-Hunt, M.S. and Wilde, P., 1994, Thermodynamic zonation in the black shale facies based on iron-manganese-vanadium content: Chemical Geology, v. 113, p. 297-317.

Quinby-Hunt, M.S., Wilde, P., Orth, C.J., and Berry, W.B.N., 1989, Elemental geochemistry of black shales; statistical comparison of low-calcic shales with other shales, in Grauch, R.I. and Leventhal, J.S., eds., Metalliferous black shales and related ore deposits: Reston, U.S. Geological Survey, p. 8-15.

Reinhardt, P., 1966, Zur Taxionomie und Biostratigraphie des fossilen Nannoplanktons aus dem Malm, der Kreide und dem Alttertiaer Mitteleuropas. Taxonomy and biostratigraphy of Malm, Cretaceous, and early Tertiary nannoplanktonic faunas of central Europe: Freiberger Forschungshefte, Reihe C: Geowissenschaften, Mineralogie-Geochemie, v. 196, p. 5-61.

Riding, R., 2002, Biofilm architecture of Phanerozoic cryptic carbonate marine veneers: Geology, v. 30, p. 31-34.

Robbins, L.L. and Blackwelder, P.L., 1992, Biochemical and ultrastructural evidence for the origin of whitings: A biologically induced calcium carbonate precipitation mechanism: Geology, v. 20, p. 464-468.

Rowland, S.J., 1990, Production of acyclic isoprenoid hydrocarbons by laboratory maturation of methanogenic bacteria: Organic Geochemistry, v. 15, p. 9-16. 
Sageman, B.B., Meyers, S.R., and Arthur, M.A., 2006, Orbital time scale and new Cisotope record for Cenomanian-Turonian boundary stratotype: Geology, v. 34, p. 125-128.

Schultze-Lam, S., Harauz, G., and Beveridge, T.J., 1992, Participation of a cyanobacterial S-layer in fine grained mineral formation: Journal of Bacteriology, v. 174, p. 7971-7981.

Sinton, C.W. and Duncan, R.A., 1997, Potential links between ocean plateau volcanism and global ocean anoxia at the Cenomanian-Turonian boundary: Economic Geology, v. 92, p. 836-842.

Sissingh, W., 1977, Biostratigraphy of Cretaceous calcareous nannoplankton: Geologie en Minjbouw, v. 56, p. 37-65.

Snow, L.J., Duncan, R.A., and Bralower, T.J., 2005, Trace element abundances in the Rock Canyon Anticline, Pueblo, Colorado, marine sedimentary section and their relationship to Caribbean plateau construction and oxygen anoxic event 2: Palaeogeography, v. 20, p. PA3005, doi:10.1029/2004PA001093.

Thompson, J.B., Ferris, F.G., and Smith, D.A., 1990, Geomicrobiology and sedimentology of the mixolimnion and chemocline in Fayetteville Green Lake, New York: Palaios, v. 5, p. 52-75.

Tribovillard, N., Trentesaux, A., Trichet, J., and Defarge, C., 2000, A Jurassic counterpart for modern kopara of the Pacific atolls: lagoonal, organic matter-rich, laminated carbonate of Orbagnoux (Jura Mountains, France): Palaeogeography, Palaeoclimatology, Palaeoecology, v. 156, p. 277-288.

Tribovillard, N.P., 1998, Cyanobacterially generated peloids in laminated, organic-matter rich, limestones; an unobtrusive presence: Terra Nova.The European Journal of Geosciences, v. 10, p. 126-130.

Tsikos, H., Jenkyns, H.C., Walsworth-Bell, B., Petrizzo, M.R., Forster, A., Kolonic, S., Erba, E., Premoli-Silva, I., Baas, M., Wagner, T., and Sinninghe Damste, J.S., 2004, Carbon-isotope recorded by the Cenomanian-Turonian Oceanic Anoxic Event: correlation and implications based on three key localities: Journal of the Geological Society of London, v. 161, p. 711-719.

United States Environmental Protection Agency, U., 1996, Test methods for evaluating solid waste, SW 846: Washington, Office of Solid Waste and Emergency Response, USEPA, p. 3500.

Voigt, S., 2000, Cenomanian-Turonian composite $\delta^{13} \mathrm{C}$ curve for Western and Central Europe: the role of organic and inorganic carbon fluxes: Palaeogeography, Palaeoclimatology, Palaeoecology, v. 160, p. 91-104. 
Wedepohl, K.H., 1971, Environmental influences on the chemical composition of shales and clays: Physics and Chemistry of the Earth, v. 8, p. 305-333.

Wedepohl, K.H., 1991, The composition of the upper earth's crust and the natural cycles of selected metals; Metals in natural raw materials. Natural resources, in Merian, E., Clarkson, T.W., Fishbein, L., Geldmacher-von Mallinckrodt, M., Piscator, M., Schlipkoeter, H.W., Stoeppler, M., Stumm, W., and Sundermann, F.W., eds., Metals and their compounds in the environment; occurrence, analysis, and biological relevance: Weinheim, VCH Verl.-Ges., p. 3-17. 


\title{
CHAPTER IX
}

\section{Cyclic sedimentation from the Cenomanian/Turonian of NE Mexico: its relationship to Milankovitch and solar cycles}

\author{
Duque-Botero Fabian, Maurrasse, Florentin J-M.R. and Melinte Mihaela Carmen \\ Submitted to Earth and Planetary Science Letters June 2006
}

\subsection{Abstract}

Sediments attributed to the Indidura Formation in the Parras Mountains, NE Mexico, show conspicuous bedding and laminae that are related to varying abundances of microspheroids of cyanobacterial origin. At Parras de la Fuente the sedimentary sequence shows a monotonous series of intercalations of highly laminated black marly calcilutites and marlstones. At the microscopic scale the sediments also exhibit intercalation patterns where light laminae are related to higher concentration of microspheroids, whereas dark laminae contain less. In order to distinguish different degrees of cyclic changes we use wavelet transform and time series analysis for $\mathrm{TOC} \%$ and $\mathrm{CaCO}_{3} \%$, which reflect the outcrop-scale variability, and gray-scale values line scans at the microscopic scale obtained from thin sections. These fluctuations mirror compositional changes due to varying climatic cycles and other variations that affected sedimentation patterns. We use calcareous nannofossils to constrain the age of the unit and determine sedimentation rates. 
Variability at the field scale can be correlated with Milankovitch precession cycles of about $23 \mathrm{ka}$ associated with changes in $\mathrm{CaCO}_{3}$ productivity controlled by variations in microspheroid content. At the microscopic scale the laminae register much shorter-term climatic variability in response to external forcing factors such as solar cycles as suggest their 10-15 year pulses similar to known solar activity.

We interpret the periodicity in the $\mathrm{CaCO}_{3}$ and TOC record as the result of fluctuating productivity of cyanobacteria, which increased during peak precession periods when low sediment supply to the basin (e.g. clays) and poor recycling of nutrients created long-term conditions for cyanobacteria to predominate. Similar situation existed at the millimetric scale, which we surmise resulted from variations in nutrient content controlled by periodic increased in pluviosity at the decadal scale. In this case enhanced supply of runoff would have generated the ligth laminae and under enhanced productivity conditions and cyanobacterial blooms, by contrast when the conditons returned to regular nutrient levels would have allowed the presence of other plankton (e.g. Foraminifera, radiolaria).

\subsection{Introduction}

The area near Parras de la Fuente, Coahuila, Mexico (Figure 9 - 1), GPS coordinates of $25^{\circ} 26^{\prime} 17.9^{\prime \prime} \mathrm{N} ; 102^{\circ} 12^{\prime} 54.7^{\prime \prime} \mathrm{W}$, offers a setting where the middle Cretaceous sedimentary sequence attributed to the Indidura Formation (Kelly, 1936) is well exposed over large distances. These rocks are characterized by distinctly rhythmical interbeds of dark, highly laminated biocalcilutites, and dark laminated marls. 


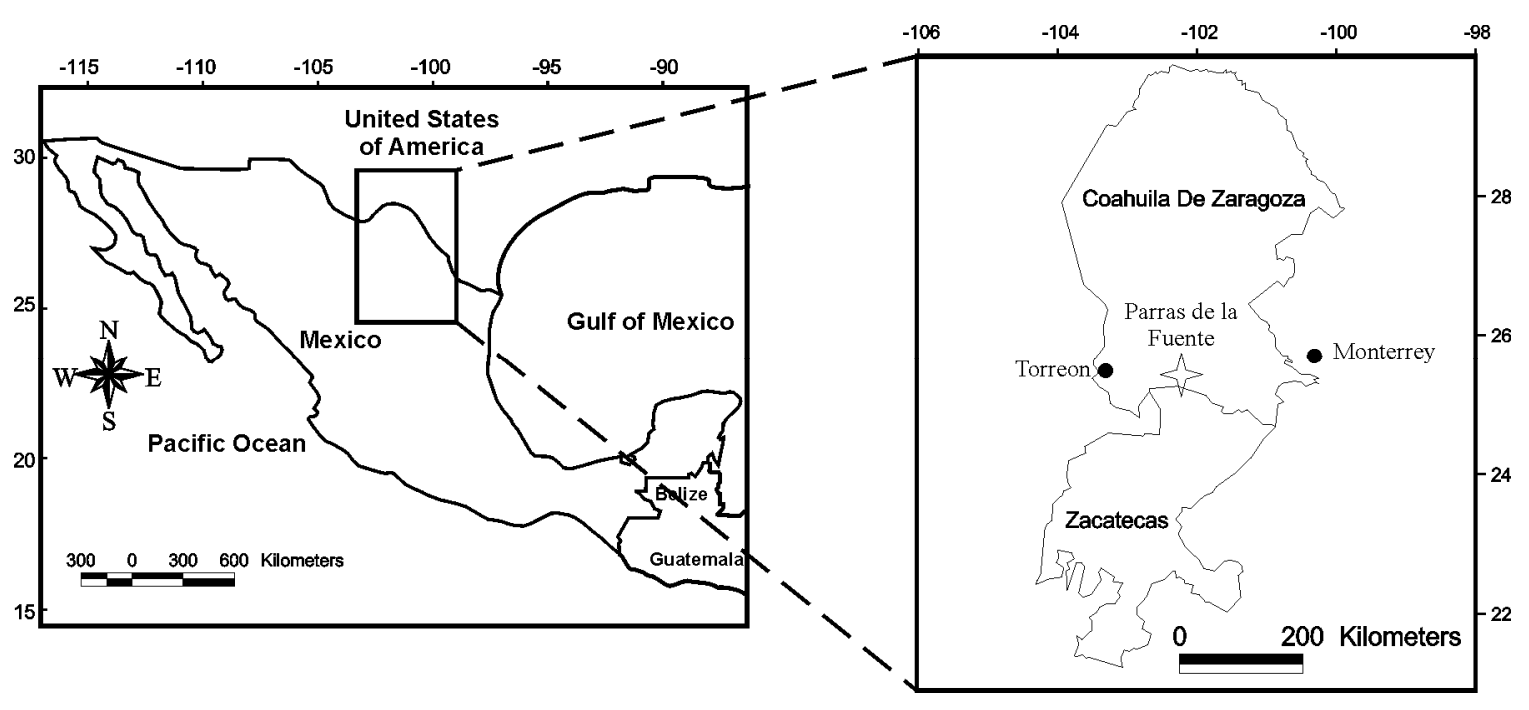

Figure 9- 1. Localization map, the star in the south central part of the Coahuila State marks the study area.

Benthic organisms are mostly absent, represented only by very rare specimens of Inoceramus labiatus?. Bioturbation is unusual, and only primary hydrodynamic sedimentary structures are readily discernible. The main difference between the calcilutites and the marls is due to varying abundance of the cyanobacterial microspheroid and clays (Duque-Botero and Maurrasse, 2005). Since previous studies of the sequence indicate that the original sediments accumulated in an environment alternately under anoxic (oxygen-free) and dysoxic (low oxygen) conditions throughout most of the succession (Duque-Botero and Maurrasse, 2005), the continuous alternation of undisturbed laminae and beds must provide information regarding high- and lowfrequency paleoenvironmental changes (e.g. decadal - millennial scales). These continuous outcrops thus offer a unique opportunity for high-resolution stratigraphic and clyclostratigraphic analyses. In the present work we investigate the cyclic pattern of the Indidura Formation at Parras de La Fuente, which was deposited during the Upper 
Cenomanian through the Middle Turonian (Kelly, 1936; Duque-Botero and Maurrasse, 2005), an interval of time known to have recorded one of the highest sea level stand (Gale et al., 2002). Concurrently, it was also a time of low oceanic oxygen conditions in both epicontinental seas and open waters (Jenkyns, 1980).

Here we present two data sets that compile a large time-series to which wavelet and spectral techniques were carried out. One set is composed of digitized laminae thickness and gray-color scale variation that is seem to be related to annual to decadal productivity changes of cyanobacterial microspheroids (Duque-Botero and Maurrasse, 2005). The other set uses the vertical variations of percentages in organic carbon in the bulk rock that larger-scale modulation in the overall productivity-preservation over millennial scales. We show evidence for a link between sedimentation patterns of marine Cretaceous sedimentary rocks to probably regional and global climatic patterns that appear to be related to solar irradiation and Milankovitch cycles.

\subsection{Background}

Sequences of laminated sediments (e.g. varves), and regular interbeds of limestone-marl, as well as calcareous-siliceous oozes have been commonly used to understand paleoclimatic variations throughout the geological record (Kemp, 2003; Pearson et al., 2004; Anderson, 1996; Hays et al., 1976; Einsele and Ricken, 1991). Several causal mechanisms have been proponed to explain the formation of such types of sedimentary patterns that range from high frequency solar cycles (Patterson et al., 2004b), to low frequency Milankovitch cycles (Schwarzacher, 1993). The common denominator of 
these cycles of varying frequencies is that external factors of oscillatory nature are intrinsically controlling and influencing condition of sedimentation in the basin (Schwarzacher, 1993). Nonetheless, in many cases a precise duration of the cycles may be conjectural because of uncertainties that arise from biases introduced in the record by synsedimentary perturbations due to burrowing, as well as possible diastems, and by overlapping cycles (Weedon, 2003).

Most recently there is an increasing literature that addresses the external factors responsible for small (daily-yearly) and larger (annually-millennia) climatic variability (Carslaw et al., 2002; Friis-Christensen and Lassen, 1991; Kemp, 2003). Observational records of high frequency cycles found in sediment deposits show good agreement with forcing factors that imply both the influence of cosmic ray and solar irradiance, which are well confined at frequencies close to the $9-12$ year Schwabe sunspot cycle (FriisChristensen and Lassen, 1991), and the 20-22 year Hale cycle. Furthermore, the 72-90 year Gleissberg sunspot cycles (Gleissberg, 1958; Garcia and Mouradin, 1998) are modulations of the Schwabe cycle. Arguably variability of solar irradiation can therefore be a major factor to influence fluctuations of global sea-surface temperatures (Jones et al., 2001). Hence, increase in solar activity that affects net flux of cosmic rays can directly enhance the overall earth's energy budget (Carslaw et al., 2002).

\subsection{Data and Methods}

The data sets used in this work to carry out the time series calculation consist of the results obtained for Total Organic Carbon \% (TOC), total carbonate \% (TIC or $\mathrm{CaCO}_{3}$ ), 
and digitized images. The scanned images of thin sections were analyzed for two signals, sediment gray-scale values, and laminae thickness. TOC \% and TIC \% were measured as weight \% with a LECO CR-412, and to obtain bed thickness the image analysis signals were transformed from thin section or stratigraphic distance into a time-scale by using the sediment ages provided by the nannofossils. The time series analysis techniques involves wavelet analysis and spectral analysis in order to determine the continuity, and periodicities that are tied to two-age frequency domains (decadal and Milankovitch). Images were acquired in TIFF-format and then edited with the COREL PHOTO-PAINT image processing software. Thin sections were scanned and digitized at a resolution of $500 \mathrm{pixel} / \mathrm{cm}^{2}$, resulting in about 3000 linear pixel/thin section. We used as well microscope images at a resolution of 1000 pixels $/ \mathrm{cm}^{2}$ of the whole thin section in order to measure individual laminae and to identify mineralogical and compositional variations. Images were acquired in 256 gray-scale intensity, where 0 is given to black and 255 to white. We used ERDAS Image 8.7 to generate gray-scale values, which were measured in strips perpendicular to the laminae, and recorded on a spreadsheet. Interpolating gray scale values from adjacent pixels further allowed to correct the data obtained for extreme gray-values caused by small calcite veins, foraminifers and other large particles.

\subsubsection{Time Series and Spectral Analysis}

We applied a continuous wavelet transform (CWT) analysis and spectral analysis to our datasets to quantify the presence of cyclicity and bandwidth dependent relations between the different time-series. Continuous wavelet transforms (CWT) are mathematical correlation functions that break the data into smaller series frequency components as 
functions of time (Patterson et al., 2004a), then each of the frequencies are individually analyzed at a resolution appropriate to its time-scale (Graps, 1995). This approach was originally described and developed by Fourier (1822), where he described that any function can be approximated by a superposition of sines and cosines.

A similar approach is used here following the Continuous wavelet transform (CWT) that has the advantage of performing analyses to both the time and the frequency domain. The CWT also uses a variable size window, enhancing its geological application. This characteristic permits CWT to delineate high-frequency changes or cycles present in sedimentary sequences (Patterson et al., 2004a). Another benefit of the CWT process is to let observe data at different frequency scales, making it particularly useful in geosciences (Graps, 1995).

We used the program Autosignal 1.7 by SYSTAT to analyze the datasets, and used a scaling ratio of 10, which has shown good resolution in the periodicity domain (Patterson et al., 2004a). We used "zero padding" at the beginning and end of the data series to reduce the edge effect; the data were standardized to a mean $=0$ and detrended. The final representation diagram in the time-frequency domain is known as a scalogram in which the data are represented in gray scale intensities.

\subsection{Results}

\subsubsection{Age of the Indidura Formation and sedimentation rate}

Biostratigraphy of the calcareous nannofossils indicates that the lower part of the 
sedimentary sequence includes the first occurrence (FO) of Quadrum gartneri Prins and Perch-Nielsen in Manivit et al., (1977). This taxon characterizes the base of CC11 Calcareous Nannoplankton Zone established by Sissingh, (1977) (abs.age $93.5+0.8 \mathrm{Ma}$ ). Similarly, nannofossil taxa such as Lucianorhabdus maleformis Reinhardt (1966), and Lithastrinus septenarius Forchheimer (1972), which appear in succession toward the upper part of the sequence are indicative of zones $\mathrm{CC} 12$ and $\mathrm{CC} 13$, respectively

(Sissingh, 1977). Based on these occurrences, we can accurately constrain the Indidura Formation at the Parras section between the Cenomanian/Turonian boundary interval (CC11 Calcareous Nannoplankton Zone) and the Middle Turonian (CC13 Calcareous Nannoplankton Zone, around a minimum age of $89.0 \mathrm{Ma}$ ). Thus, we calculated that the mean compacted sedimentation rates for the intervals analyzed are $6.2 \mathrm{~cm} / \mathrm{ka}(\mathrm{CC} 11)$ and $10.1 \mathrm{~cm} / \mathrm{ka}(\mathrm{CC} 12)$.

\subsubsection{Stratification patterns from field observation and geochemical (TOC/TIC) trends from samples of the Indidura Formation}

Interbeds of indurated (marlstones) and friable calcareous shale (highly laminated marly biocalcilutites) bedsets are readily identified at the outcrop scale, where their weathered surfaces show a light orange to a light gray color, respectively. Fresh surfaces of these rocks show their actual color from light olive gray (5Y6/1) for the marlstones, and brownish black to olive black (5YR2/1 - 5Y2/1) for the laminated marly biocalcilutites. On the overall, the friable calcareous shale intervals vary in thickness between 5 to 200 $\mathrm{cm}$, and the marlstone beds fluctuate in thickness between 8 and $100 \mathrm{~cm}$. The interbedding pattern becomes more persistent and layer thickness decreases toward the 
middle of the upper part of the section where the different lithologic units reach only between about 12 and $15 \mathrm{~cm}$ in the section studied at Parras de la Fuente. TOC/TIC values reflect the recurrent stratification pattern that is produced mainly by periodic variation of carbonate-rich and carbonate-poor lithologies with $\mathrm{CaCO}_{3}$ ranging from $27 \%$ to $89 \%$ with an average of $68 \%$. TOC ranges from $0.3 \%$ to $3.6 \%$, and is consistently above $1.3 \%$. A pattern of high TOC \% that correlates with low $\mathrm{CaCO}_{3}$ corresponds to the marlstone beds, while the inverse relationship is observed in the highly laminated marly biocalcilutites, which consist predominately of calcareous microspheroids of cyanobacterial origin (Duque-Botero and Maurrasse, 2005).

\subsubsection{Stratification patterns observed from digital images, and microscopic composition of samples from the Indidura Formation}

Major compositional differences are readily observed with the naked eye in the thin sections, where counting can be done directly. However, because of the extreme thinness of some laminae that might escape the measurement, we chose instead microphotographic techniques at higher magnification. The higher resolution of observation thus permitted to clearly observe that laminae are composed of discrete units 10 to $500^{+}$micrometer thick. They vary regularly from dark lamina, rich in clay and organic matter (gray-scale value $<100$ ) to light and bright lamina, rich in microspheroids (gray-scale value $>100$ ). On the whole, dark laminae account for more areal extent than the light laminae, both of which create lamina sets of several millimeters thick. Laminae are arranged as even-parallel to wavy-parallel, although some were observed in curved non-parallel arrangement, implying occasional low-energy hydrodynamic processes 
during sedimentation. Although laminae at both the outcrop and thin section levels appear to be fairly continuous (Figure 9-2A), under higher magnification it can be observed that the rocks have a characteristic pinch and swell lamination (Figure $9-2 \mathrm{~A}$ ) pattern that is more evident in the light laminae where micrite, clays, and possible organic matter are found in small concentrations or as envelopes surrounding microspheroids (Figure 9 - 2B). Lamina sets show no apparent evidence of micro boring or bioturbation,
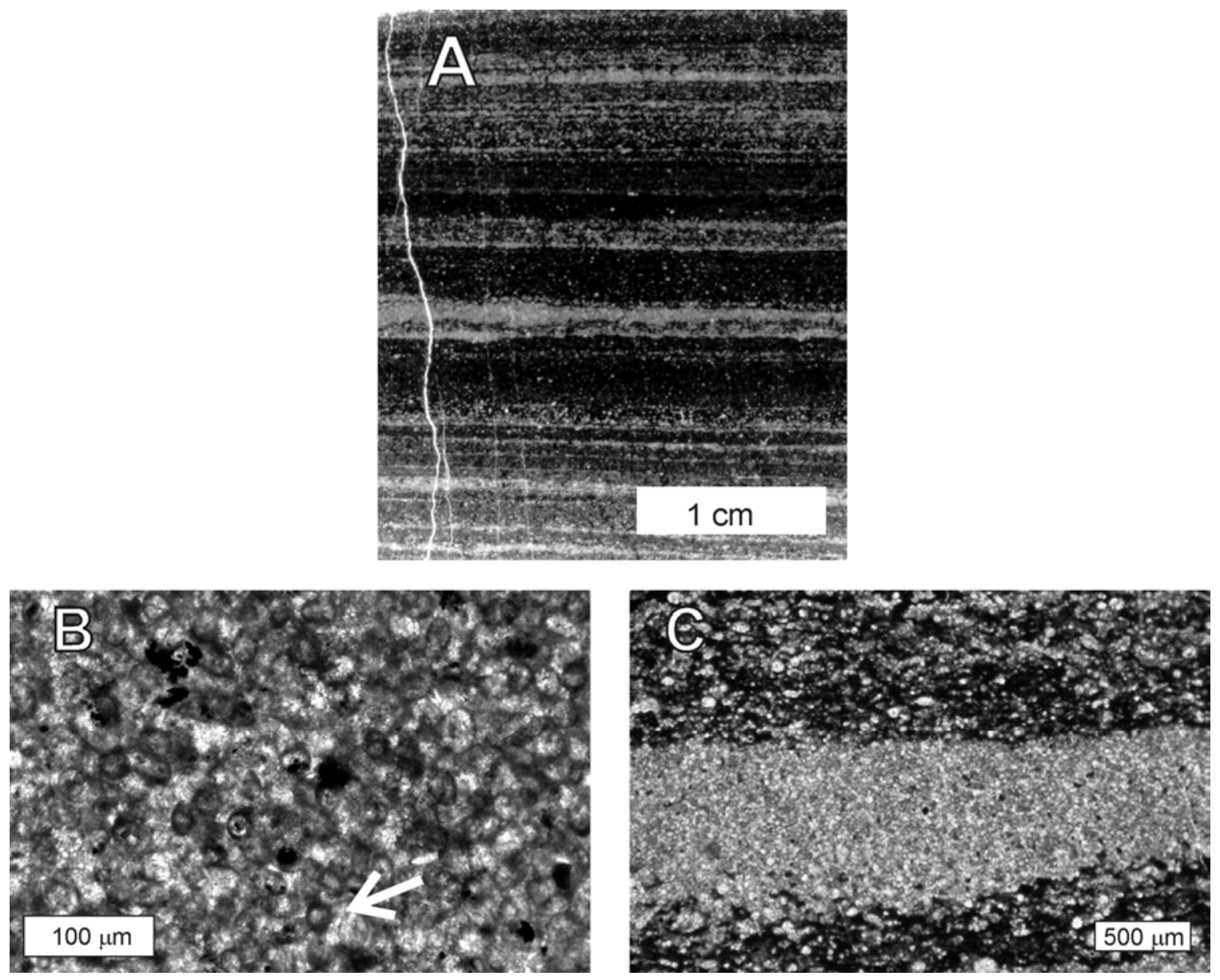

Figure 9-2. Thin sections microphotographs of highly laminated calcilutites that exhibit parallel to even parallel laminae very thin laminae $<3 \mathrm{~mm}$., and show pinch and swell structures. B) Close up view of $\mathrm{C}$, arrow shows a calcareous microspheroid that exhibits an organic matter coating. B) Calcareous microspheroids are commonly found forming parallel to even parallel laminae and can account for up to $95 \%$ of the material found in the laminae. All scales inside figures. 
hence they seem to be the record of original existing hydrodynamic conditions at the time of deposition.

Intervals composed of black laminated marly calcilutites show internal compositional differences between the light and dark laminae as observed in Figure 9 - 2 A and C, as compared to the marlstone beds, which display a less organized arrangement of individual laminae that are harder to delineate.

The main constituents of the different lithologies are microspheroids ranging in size between 5 and $100 \mu \mathrm{m}$, with a predominant size range of 20 to $40 \mu \mathrm{m}$, and a median size of $20 \mu \mathrm{m}$. SEM and petrographic analyses (Duque-Botero and Maurrasse, 2005) of the Parras de la Fuente sequence also show that all microspheroids originated from calcified cyanobacterial microspheroids of varying abundance throughout. Light laminae are composed almost entirely ( $>95 \%$ ) of microspheroids (Figure 9 - 2C), and up to about $50 \%$ in the dark laminae, which may also include scarce foraminifera and radiolaria (Figure 9 - 3).

\subsection{Spectral and time series analyses}

\subsubsection{TOC and $\mathrm{CaCO}_{3}$}

The wavelet analysis carried out here covers the geochemical analyses of the middle part of the Indidura Formation at Parras de la Fuente (Duque-Botero, 2006) in the interval between 149 and 163 meters. The data indicate that strong cyclicity bands are present at 27, 50, 100 and $200 \mathrm{~cm}$, respectively (Figure 9 - 4 A, B), which correspond to different 

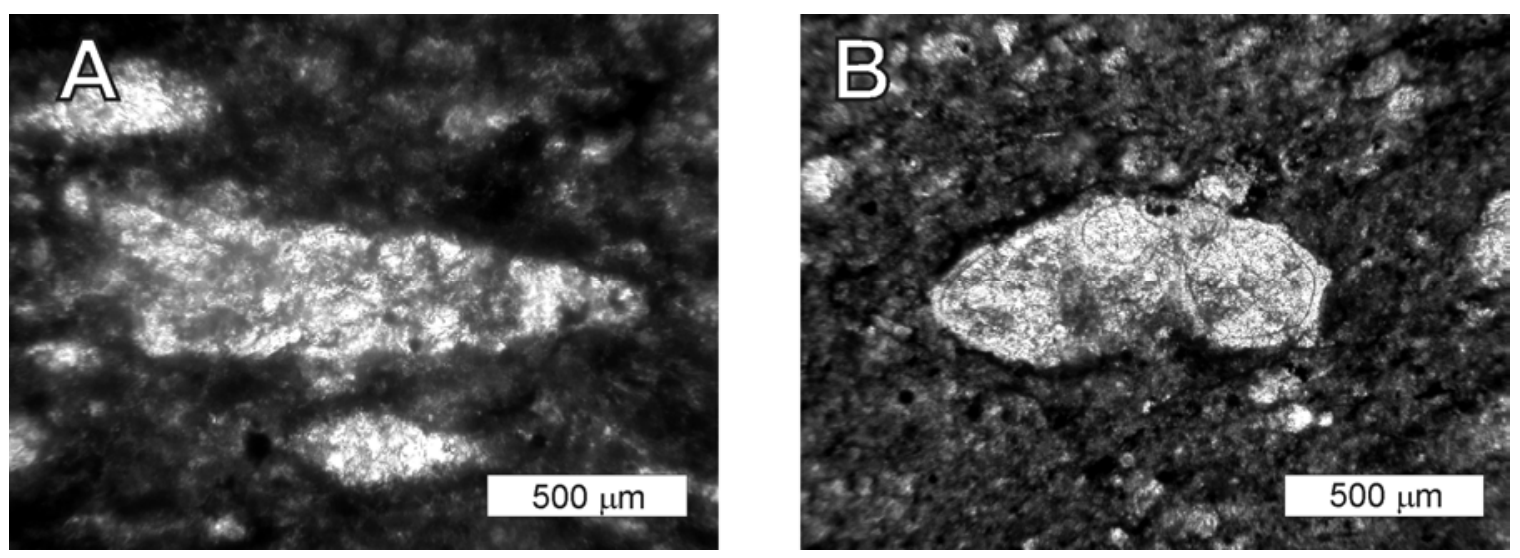

Figure 9- 3. Scatter microfossils like the ones seen in A (Radiolaria) and B (Foraminifera) are found in the dark laminae and in the marlstones.

intervals in the stratigraphic section with elevated values in $\mathrm{TOC}$ and $\mathrm{CaCO}_{3}$. By converting these results to calendar years, according to a mean compacted sedimentation rate of $10.1 \mathrm{~cm} / \mathrm{ka}$, we obtain an observed cyclicity roughly equal to $2,700,5,000,10,000$ and 20,000 years, respectively (Figure 9 - 4 A, B). Further observation shows that the stronger signal for the interval is around the 2,800 years band, although such cycle has a patch nature. Similar signal is associated with the time interval close to 5,000 years showing the same patchy nature (Figure 9 - 4 A,B). On the other hand, although the signals found around 10,000 and 20,000 years show less power, the continuity over the sample interval is more pronounced. Overall the signal at the $20 \mathrm{ka}$ band has less power than the other signals found in the interval (Figure 9 - 4 A,B).

\subsubsection{Thin sections}

Wavelet analysis of the gray-value from thin section microphotographs displays recurrent areas with low color variation in contrast with areas of strong high-frequency cyclicity bands appearing at different levels of the stratigraphic succession. Detailed wavelet 

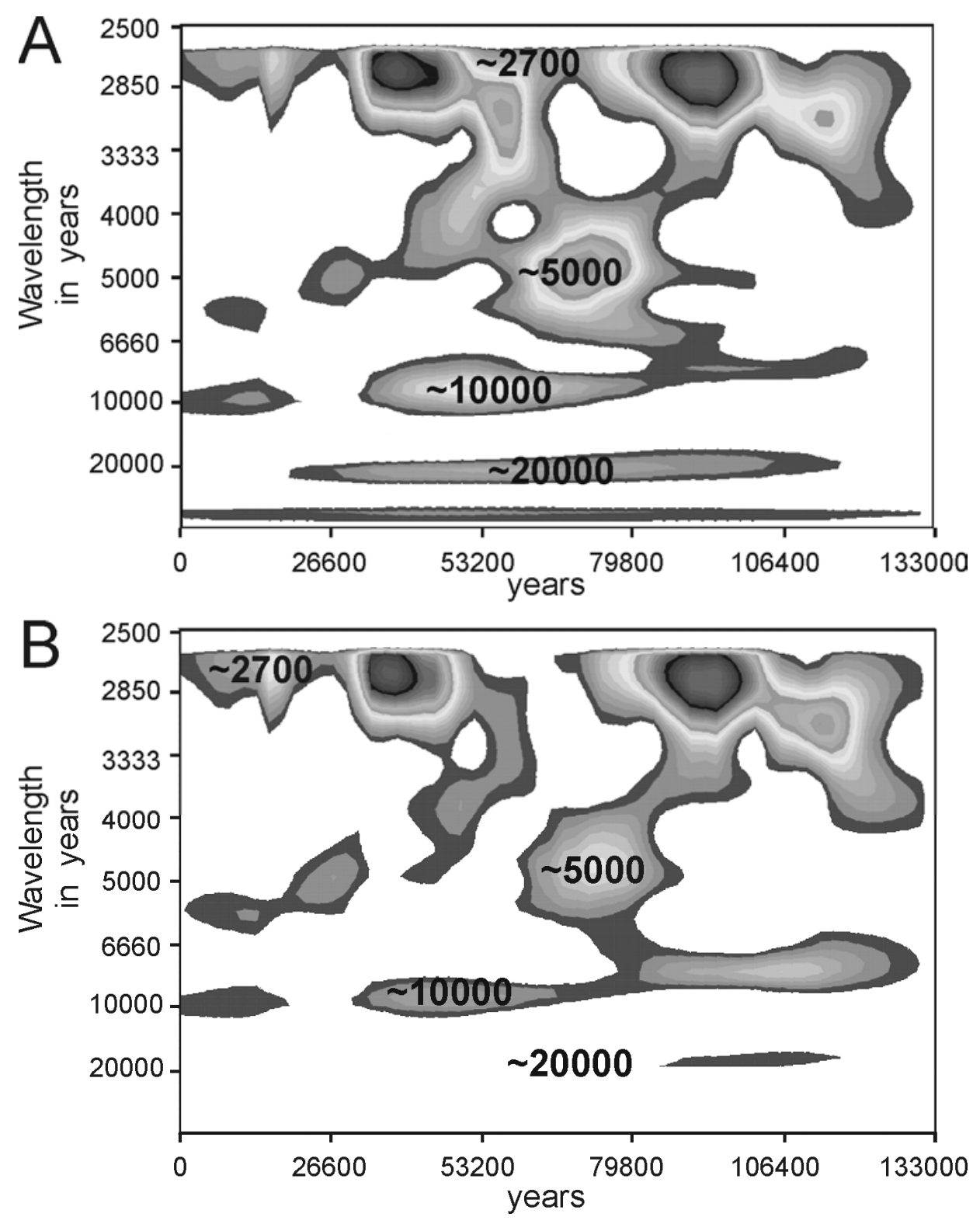

Figure 9- 4. Wavelet analysis (using Morlet wavelength with a window size of 10) of: A) total organic carbon (TOC wt \%) and $\mathrm{B}$ ) total carbonate ( $\mathrm{CaCO} 3 \mathrm{wt} \%)$. Gray scales indicate the magnitude of the wavelet in 24 tones. Numbers in the scalogram indicate the wavelengths that are representative for the variability within the data sample. The more continuous wavelengths are close to $10 \mathrm{ka}$ and $20 \mathrm{ka}$; while the ones with more spectral power are those close to 2,700 and 5,000 years.

analysis were carried out in three thin sections from different intervals of the Indidura Formation applying compacted sedimentation rates of $6.2 \mathrm{ka}$ for sample MX-239, and 
10.1 ka for samples MX-01 and MX-08, respectively. The results shown here correspond to gray scale intensity (GSI) and lamina counting (LC). GSI analysis for MX-01 (Figure $9-5 B)$ shows a cyclicity band between 10 to 13 years that is more prominent toward the

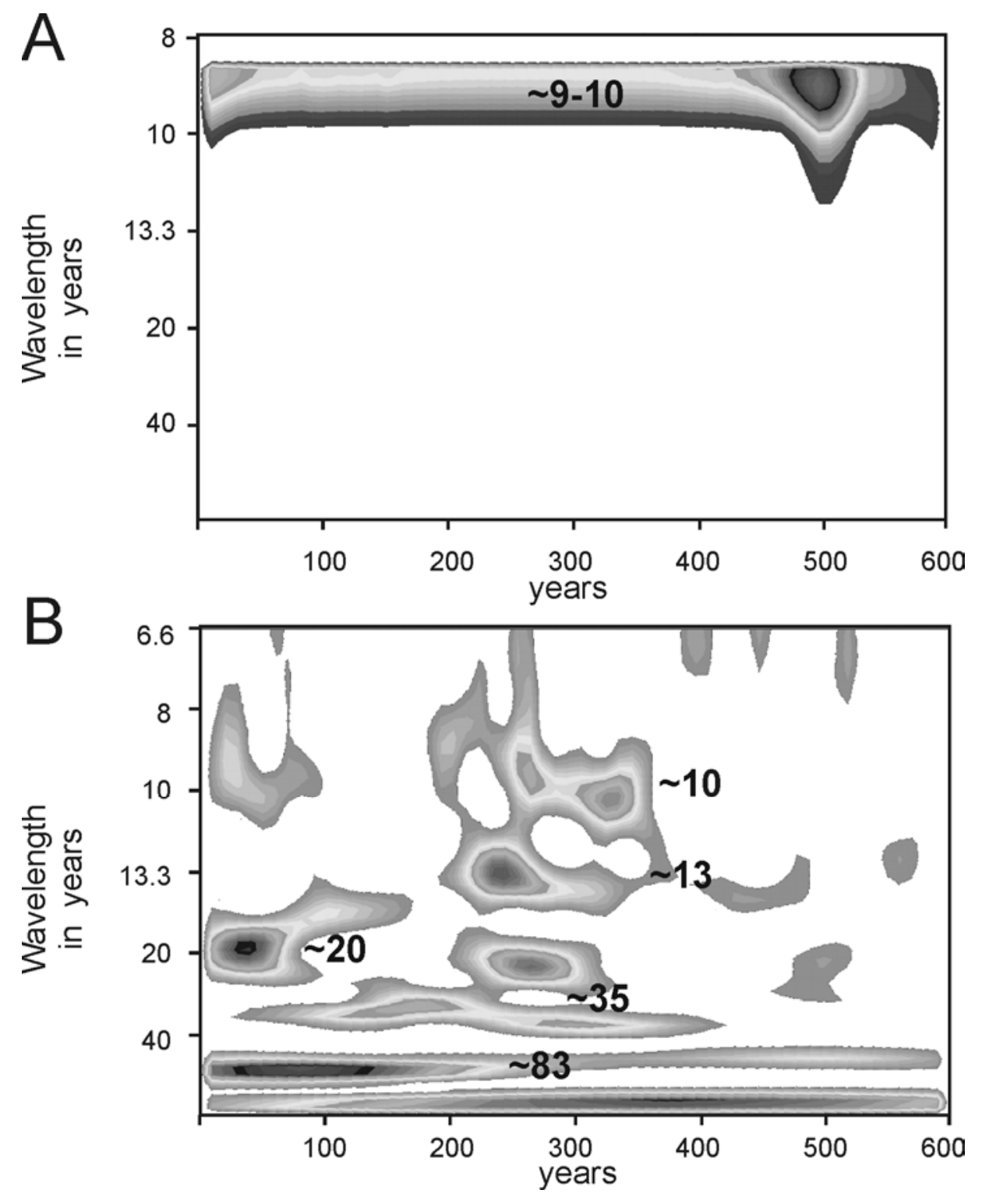

Figure 9- 5. Wavelet analysis of sample MX-01 (using Morlet wavelength with a window size of 10). A) Lamina counting (LC) and B) gray scale intensity (GSI) of laminae. Gray scales indicate the magnitude of the wavelet in 24 tones. Numbers in the scalogram indicate the wavelengths that are representative for the variability within the data sample. Only one prominent wavelength in the LC (A) is found close to the 9 to 10 years periodicity, while the GSI (B) reveals other wavelengths at 20, 35 and 83 years. 
middle part of the thin section analyzed; there is also a strong peak cycle around 20 years in the lower part of the thin section. These cycles are concurrent with an attenuated signal peak close to 35 years followed by a continuous and strong cycle near 83 years
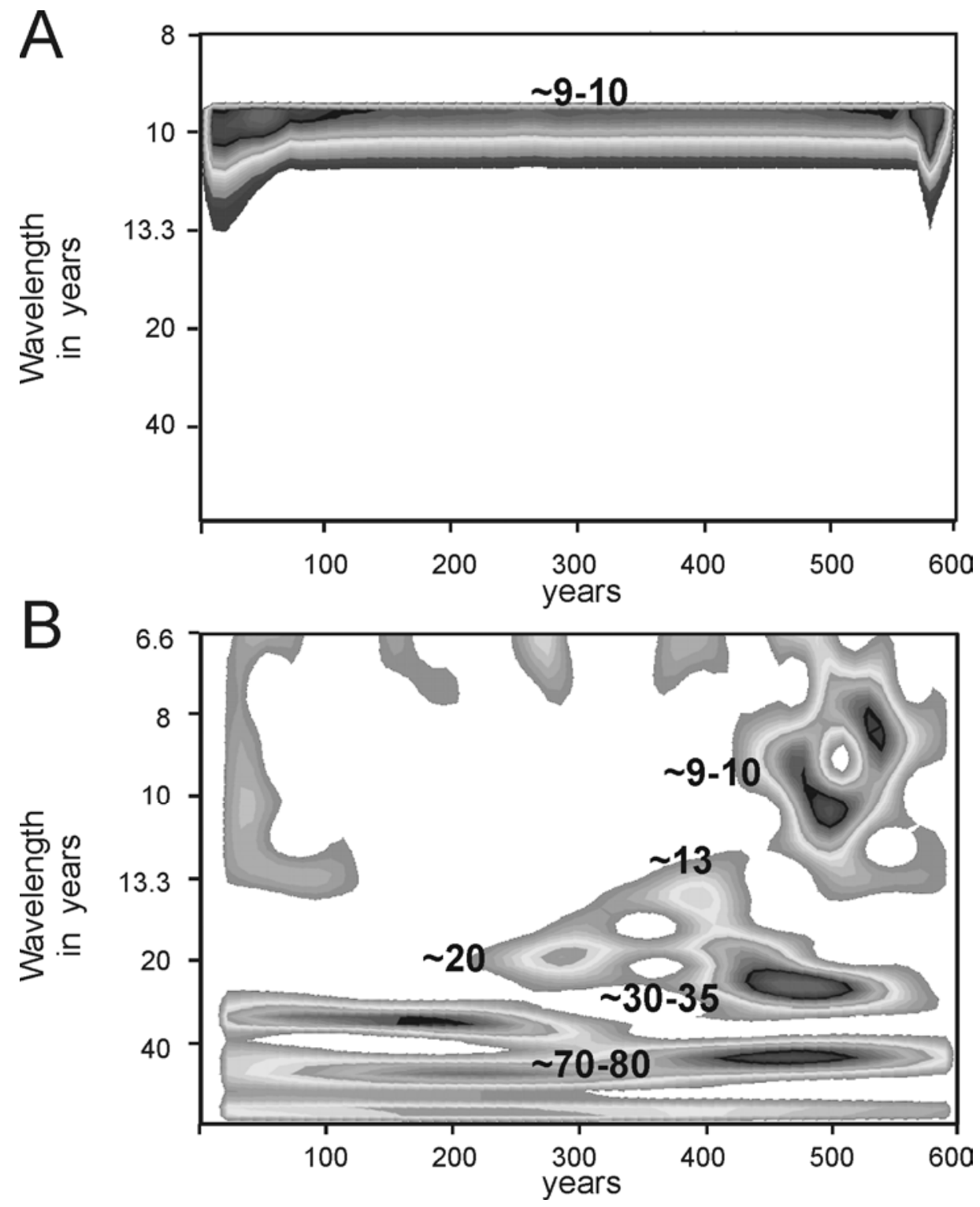

Figure 9- 6. Wavelet analysis of sample MX-08 (using Morlet wavelength with a window size of 10). A) Lamina counting (LC) and B) gray scale intensity (GSI) of laminae. Gray scales indicate the magnitude of the wavelet in 24 tones. Numbers in the scalogram indicate the wavelengths that are representative for the variability within the data sample. Only one prominent wavelength in the LC (A) is found close to the 9 to 10 years periodicity, while the GSI (B) reveals other wavelengths at 20,30 to 35 and 70 to 83 years. 
throughout the sample analyzed. In contrast to the GSI, the LC (Figure 9 - 5A) analysis signal is centered, and focus on a small but continuous cyclicity interval approximately 9 to 10 years, which exhibits stronger amplitude toward the upper part of MX-01.
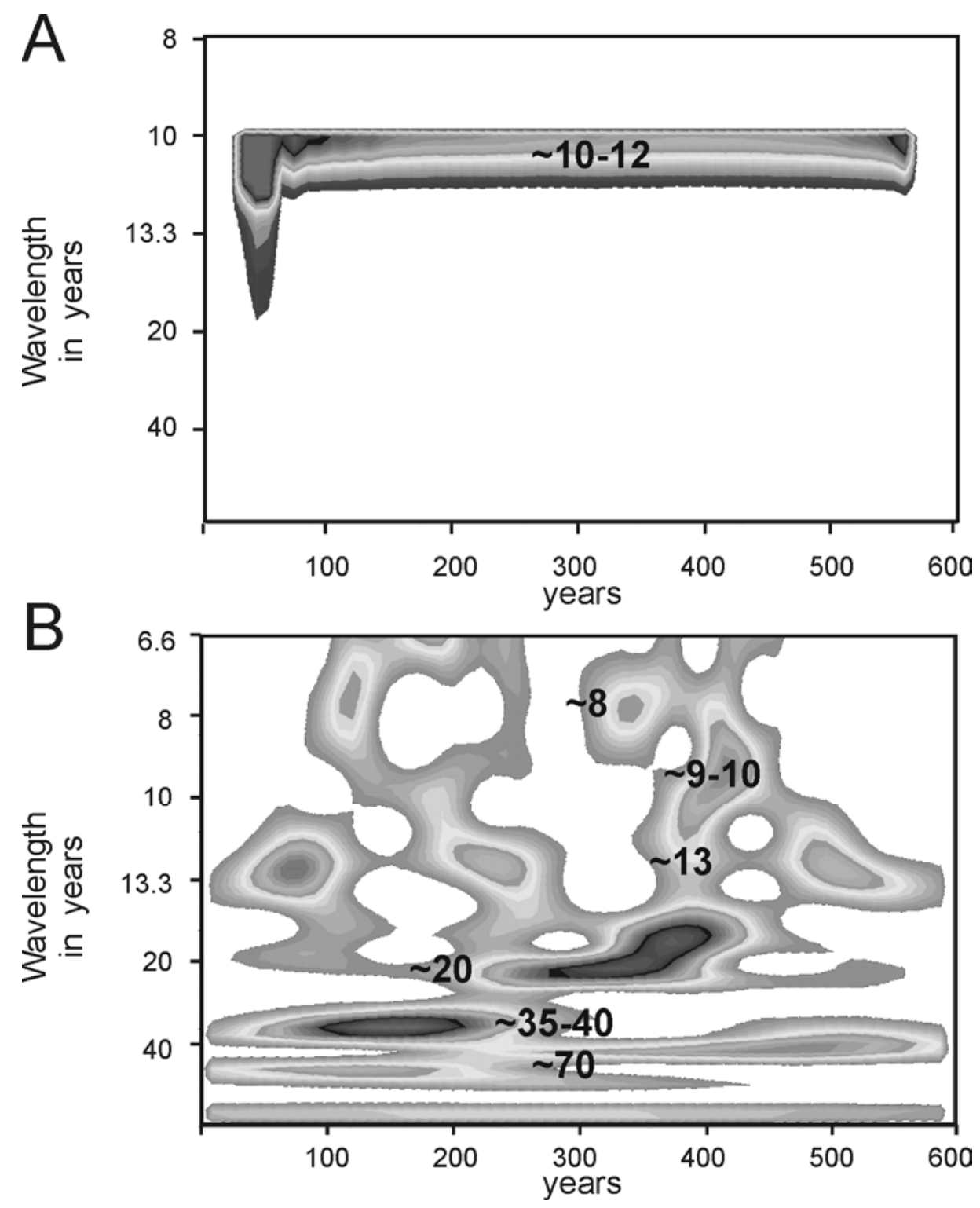

Figure 9- 7. Wavelet analysis of sample MX-239 (using Morlet wavelength with a window size of 10). A) Lamina counting (LC) and B) gray scale intensity (GSI) of laminae. Gray scales indicate the magnitude of the wavelet in 24 tones. Numbers in the scalogram indicate the wavelengths that are representative for the variability within the data sample. Only one prominent wavelength in the LC (A) is found close to the 10 to 12 years periodicity, while the GSI (B) reveals other wavelengths at 20,35 to 40 and 70 years. 
MX-08 GSI analysis (Figure 9-6B) shows a strong cyclicity concentrated close to 9-10

and 13 years, although manifested only in the lower and upper parts of the thin section. A continuous cyclicity band is also observed around 30 to 35 years, followed by another one closest to 80 years; both signals extend throughout the sample. In contrast to the distribution pattern of the GSI, the LC analysis (Figure 9 - 6A) shows a solid cyclicity band near 9 to 10 years.

Sample MX-239 shows the most variation in the GSI (Figure 9 - 7B), with an ample band that has cycles with peaks from around 8 to 13 years, with the latter showing an almost continuous band. The succeeding peak is centered at about 20 year cycles with strong amplitude in the middle part of the sample. The next order cycle is a continuous band between 35 and 40 years. Another cyclicity band is observed from 70 to 80 years. LC analysis for MX-239 (Figure 9 - 7A) shows a strong and continuous signal that centers near 10-12 year cycle.

\subsection{Discussion of results}

Continuous wavelet analysis (CWA) of laminae count (LC) based on sediment color or gray scale intensity values (GSI), integrated with total organic carbon (TOC) and carbonate $\left(\mathrm{CaCO}_{3}\right)$ derived from field samples and thin sections of the Upper Cenomanian/Middle Turonian Indidura Formation of NE Mexico shows a wide and variable spectrum of both stationary and non-stationary cycles that range from decadal to millennial scales. 


\subsubsection{Millennial Scale}

At the field scale centimeter to decimeter-thick interbeds in the middle part of the stratigraphic section of the Indidura Formation at Parras de la Fuente are compatible to regional and global climatic changes with periodicity around 20 ka (Figure 9 - 4). The CWA results also show signals at 2.7, 5 and $10 \mathrm{ka}$ (Figure 9 - 4), which are below the resolution of the Milankovitch cycles, and are harmonics of the precession cycle. The 20 ka cycle is exhibited in both the CWA for $\mathrm{TOC}$ and $\mathrm{CaCO}_{3}$, which implies that common forcing factors contributed to the preservation of the organic matter as well as the carbonate components, thus leading to the formation of intervals either rich or poor in $\mathrm{TOC} / \mathrm{CaCO}_{3}$.

Similar cyclicity has been demonstrated in other Tethyan and peri-Tethyan Cenomanian/Turonian sequences (Meyers et al., 2001; Sageman et al., 2006; Negri et al., 2003). Computer simulations for the Cretaceous Western Interior Seaway (KWIS) and Africa for the Cenomanian/Turonian time interval (Floegel et al., 2005; Floegel and Wagner, 2006) show that earth's precessional cycles with an approximate period of 21 ka were the controlling factors in the formation of bedding couplets. Such models are in agreement with the results of our analyses of the sedimentary sequence of the Indidura Formation, which further corroborate similar studies (Meyers et al., 2001; Pratt, 1984) on rock sequences deposited in the KWIS during the Cenomanian/Turonian. One marked difference between our dataset and these studies (Meyers et al., 2001; Pratt, 1984) is that the Parras sequence does not show higher-order eccentricity and obliquity cycles. The discrepancy may be related to the expanded section at Parras de La Fuente where 
sedimentation rates were higher. Although results from climate system modeling (Floegel et al., 2005) indicate that couplets related to precession cycles should be less likely in sequences near Texas and Mexico, but results based on field studies and direct sample analyses (Zhou and Longoria, 1996) show that a periodicity of approximately $20 \mathrm{ka}$ is recorded in northeastern Mexico. Our data further suggest a greater similarity with the Cretaceous Western Interior Seaway than previously predicted. Thus, comparable environmental conditions must have prevailed long enough in the northeastern Mexico basin to allow the formation of similar sedimentary patterns as the result of global climatic perturbations induced by earth's precession. These cyclic fluctuations are indeed recorded in the preservation and productivity of $\mathrm{TOC}$ and $\mathrm{CaCO}_{3}$ in the Indidura and Agua Nueva Formations of NE Mexico.

The sedimentary cycles of the Indidura Formation show that layers rich in carbonate are devoid of regular planktonic microfossils (planktonic foraminifera, radiolaria) and enriched in cyanobacterial microspheroids (Duque-Botero and Maurrasse, 2005); whereas carbonate poor beds show regular planktonic microfossils and less cyanobacterial microspheroids. Periodic dominance of cyanobacteria at the exclusion of other microorganisms is compatible with previous models (Pratt, 1984; Floegel et al., 2005) that imply overall climatic conditions conducive to the development of a stratified water column with a thin layer of fresh water at the surface. Such conditions would exclude regular plankton while benefiting cyanobacterial blooms, and cause oxygen depletion of the bottom waters. 


\subsubsection{Decadal Scale}

Continuous wavelet analysis (CWA) of individual beds (Lamina counting) of laminated sediments from the Indidura Formation show the presence of very fine laminae (Figure 5, $6,7)$ that are found regularly at a periodicity of 9 to 10 years, and their harmonics at approximately 20, 30 and 70 to 90 years (Figures 5, 6,7), which are known in the present as modulations of the Schwabe sunspot cycle. Comparable high-frequency records have been described in modern marine sequences with conditions of deposition characterized by oxygen deficiency or anoxia that have allowed the preservation of yearly fluctuations in productivity (Pilskaln and Pike, 2001; Patterson et al., 2004b; Cotillon et al., 2000). Such record in the hemipelagic sediments of the Indidura Formation at Parras de la Fuente was enhanced because of the elevated rate of sedimentation $(6.2$ to $10.1 \mathrm{~cm} / \mathrm{ka}$ of compacted sedimentation rate).

Similar laminated pattern has also been documented in Jurassic marine sediments of the white stone band of the Kimmeridge Clay Formation, where micrometer scale laminae are believed to be the result of interannual changes in the productivity of calcareous nannofossils (Pearson et al., 2004). The La Luna Formation (Cenomanian/Turonian) in northeastern South America also includes micrometer scale laminae interpreted to be the result of 6, 10-12 and 20-24 year cycles (Cotillon et al., 2000). Likewise, our dataset derived from petrological observations is indicative of significant yearly paleoproductivity variations controlled by decadal cycles that correlate with solar activity. 
Thus, microlaminae of the Indidura Formation at Parras de La Fuente were generated by rhythmical variation in the abundance of calcareous cyanobacterial microspheroids, following a decadal cycle analogous to the processes suggested for the coeval Cretaceous Interior Seaway (Floegel et al., 2005; Floegel and Wagner, 2006) where the main controlling mechanism is related to solar Schwabe cycles that affected atmospheric pressure cells and precipitation patterns and intensities, as documented in stable isotopes and clays in the KWIS area (Pratt, 1984; Arthur et al., 1985), and strontium isotopes in the Mediterranean sapropels (Krom et al., 2002). In addition to low surface water salinity that enhanced stratification in the water column, the overall greenhouse conditions in the Cretaceous must have further exacerbated oxygen depletion and intensified anoxia in subsurface waters of the oceans. In fact, an important feature of the sedimentary record of the Indidura Formation at Parras de la Fuente is that despite evidence of oxygenic primary productivity in the upper water column (nannoplanktons, rare planktonic foraminifera and radiolaria), the absence of macro and micro bioturbation indicates dysoxic / anoxic conditions at the bottom. However, a few intervals show macroscopic trace fossils.

The fact that laminae commonly occur in an even-parallel to wavy-parallel arrangement also implies extremely low-energy hydrodynamic conditions remained constant during sedimentation. Intermittent absence of planktonic organisms such as planktonic foraminifera and radiolaria further supports our interpretation that periodical freshwater input affected surface waters by excluding the stenohaline groups, while enhancing cyanobacteria/bacterial productivity. Such mechanism explains why microspheroid-rich 
laminae are devoid of eukaryotic microfossils, and the opposite occurs in microspheroidpoor laminae.

\subsection{Conclusions}

Stratification patterns of the Indidura Formation near Parras de la Fuente in northeastern Mexico show meter-scale to micrometer-scale recurrent variations attributable to global climatic forcing factors recorded as microspheroid rich/poor sediments throughout the Upper Cenomanian to the Middle Turonian.

Large-scale fluctuations are correlated with global climatic changes related to astronomic forcing of precession cycles with a periodicity around $20 \mathrm{ka}$. Such variations shifted trends of pluviosity that generated perennial conditions favorable to sustained blooms of cyanobacteria-induced calcareous microspheroids. High bacterial productivity further decreased the oxygen levels and helped maintain dysoxic/anoxic waters, as recorded in these sediments over more than four million years.

High-frequency fluctuations recorded at the micrometer scale are characterized by microspheroid-rich/poor laminae, which developed in response to short-term global climatic variations that correlate with Schwabe solar cycles that created decadal periods of increased pluviosity.

The net effect of global climatic forcing in Cenomanian-Turonian deposits in the Parras de la Fuente area was the creation of an environmental setting where at least the 
sediment/water interphase was anoxic during most of that time. These conditions further contributed to periodic exclusion of stenohaline eukaryotic microorganisms while allowing almost continuous production of calcareous cyanobacterial microspheroids.

\subsection{Acknowledgment}

This work was partially funded by the Dissertation Year Fellowship of Florida International University, awarded to Fabian Duque-Botero; the Glenn A. Goodfriend Memorial funds, and other private funding sources. The authors of this paper are deeply grateful Mr. Ignacio Chacon and to the people of Parras who collaborated during the field excursions. This is contribution No. 06-02 of the Sedimentology and Stratigraphy group at FIU. 


\subsection{References}

Anderson, R.Y., 1996, Seasonal sedimentation: a framework for reconstructing climatic and environmental change, in Kemp, A.E.S., ed., Palaeoclimatology and palaeooceanography from laminated sediments: London, Geological Society, p. 115.

Arthur, M.A., Dean, W.E., Pollastro, R.M., Claypool, G.E., and Scholle, P.A., 1985, Comparative geochemical and mineralogical studies of two cyclic transgressive pelagic limestone units, Cretaceous Western Interior Basin, U.S, in Pratt, L.M., Kauffman, E.G., and Zelt, F.B., eds., Fine-grained deposits and biofacies of the Cretaceous Western Interior Seaway; evidence of cyclic sedimentary processes: Tulsa, Society of Economic Paleontologists and Mineralogists, p. 16-27.

Carslaw, K.S., Harrison, R.G., and Kirkby, J., 2002, Cosmic Rays, Clouds, and Climate: Science, v. 298, p. 1732-1737.

Cotillon, P., Picard, A., and Tribovillard, N., 2000, Compared cyclicity and diagenesis of two anoxic deposits in the Caribbean domain: The Pleistocene-Holocene of Cariaco Basin (Site 1002) and the Upper Cretaceous La Luna-Querecual formation (north Venezuela): Proceedings of the Ocean Drilling Program: Scientific Results, v. 165, p. 125-140.

Duque-Botero, F., 2006, Paleoenvironmental Variations of the Indidura Formation (Cenomanian /Turonian), Northeastern Mexico: A High Resolution Stratigraphic Study, Ph.D. Dissertation, Miami: Florida International University, p. 172.

Duque-Botero, F. and Maurrasse, F.J.-M.R., 2005, Cyanobacterial productivity, variations in the organic matter and facies of the Indidura Formation (Cenomanian-Turonian), Northeastern Mexico: Journal of Iberian Geology, v. 31, p. 87-100.

Einsele, G. and Ricken, W., 1991, Limestone-marl alternations; an overview, in Einsele, G., Ricken, W., and Seilacher, A., eds., Cycles and events in stratigraphy: Berlin, Springer Verlag, p. 23-47.

Floegel, S., Hay, W.W., DeConto, R.M., and Balukhovsky, A.N., 2005, Formation of sedimentary bedding couplets in the Western Interior Seaway of North America-implications from climate system modeling: Palaeogeography, Palaeoclimatology, Palaeoecology, v. 218, p. 125-143.

Floegel, S. and Wagner, T., 2006, Insolation-control on the Late Cretaceous hydrological cycle and tropical African climate--global climate modelling linked to marine climate records: Palaeogeography, Palaeoclimatology, Palaeoecology, v. 235, p. 288-304. 
Forchheimer, S., 1972, Scanning electron microscope study of Cretaceous coccoliths: Lund, Lunds University, PhD Dissertation, p. -141.

Fourier, J.B.J., 1822, Theorie analytique de la chaleur: Paris, F. Didot, p. 639.

Friis-Christensen, E. and Lassen, K., 1991, Length of the solar cycle: an indicator of solar activity closely associated with climate: Science, v. 254, p. 698-700.

Gale, A.S., Hardenbol, J., Hathway, B., James Kennedy, W., Young, J.R., and Phansalkar, V., 2002, Global correlation of Cenomanian (Upper Cretaceous) sequences: Evidence for Milankovitch control on sea level: Geology, v. 30, p. 291-294.

Garcia, A. and Mouradin, Z., 1998, The Gleissberg Cycle of minima: Solar Physics, v. 180, p. $495-498$.

Gleissberg, W., 1958, The eighty-year sunspot cycle: Journal of British Astronomical Association, v. 68, p. 1148-1152.

Graps, A., 1995, An Introduction to Wavelets: IEEE Computational Science and Engineering, v. 2, p. 50-61.

Hays, J.D., Imbrie, J., and Shackleton, N.J., 1976, Variations in the Earth's Orbit: Pacemaker of the Ice Ages: Science, v. 194, p. 1121-1132.

Jenkyns, H.C., 1980, Cretaceous anoxic events; from continents to oceans: Journal of the Geological Society of London, v. 137, p. 171-188.

Jones, P.D., Osborn, T.J., and Briffa, K.R., 2001, The Evolution of Climate Over the Last Millennium: Science, v. 292, p. 662-667.

Kelly, W.A., 1936, Evolution of the Coahuila Peninsula, Mexico; Part 2, Geology of the mountains bordering the valleys of Acatita and Las Delicias: Geological Society of America Bulletin, v. 47, p. 1009-1038.

Kemp, A.E.S., 2003, Evidence for abrupt climate changes in annual laminated marine sediments: Philosophical Transactions - Royal Society.Mathematical, Physical and Engineering Sciences, v. 361, p. 1851-1870.

Krom, M.D., Stanley, J.D., Cliff, R.A., and Woodward, J.C., 2002, Nile River sediment fluctuations over the past $7000 \mathrm{yr}$ and their key role in sapropel development: Geology, v. 30, p. 71-74.

Manivit, H., Perch-Nielsen, K., Prins, B., and Verbeek, J.W., 1977, Mid Cretaceous calcareous nannofossil biostratigraphy: Proceedings of the Koninklijke Nederlandse Akademie van Wetenschappen, v. 80, p. 169-181. 
Meyers, S.R., Sageman, B.B., and Hinnov, L.A., 2001, Integrated quantitative stratigraphy of the Cenomanian-Turonian Bridge Creek Limestone Member using evolutive harmonic analysis and stratigraphic modeling: Journal of Sedimentary Research, v. 71, p. 628-644.

Negri, A., Cobianchi, M., Luciani, V., Fraboni, R., Milani, A., and Claps, M., 2003, Tethyan Cenomanian pelagic rhythmic sedimentation and Pleistocene Mediterranean sapropels: is the biotic signal comparable?: Palaeogeography, Palaeoclimatology, Palaeoecology, v. 190, p. 373-397.

Patterson, D.T., Prokoph, A., Wright, C., Chang, A.S., Thomson, R.E., and Ware, D.M., 2004a, Holocene Solar Variability and Pelagic Fish Productivity in the NE Pacfic: Palaeontologia Electronica, v. 7, p. 17-http://palaeoelectronica.org/2004_1/fish2/issue1_04.htm.

Patterson, R.T., Prokoph, A., and Chang, A., 2004b, Late Holocene sedimentary response to solar and cosmic ray activity influenced climate variability in the NE Pacific: Sedimentary Geology, v. 172, p. 67-84.

Pearson, S.J., Marshall, J.E.A., and Kemp, A.E.S., 2004, The White Stone Band of the Kimmeridge Clay Formation, an integrated high-resolution approach to understanding environmental change: Journal of the Geological Society, v. 161, p. 675-683.

Pilskaln, C.H. and Pike, J., 2001, Formation of Holocene sedimentary laminae in the Black Sea and the role of the benthic flocculent layer: Paleoceanography, v. 16, p. $1-19$.

Pratt, L.M., 1984, Influence of paleoenvironmental factors on preservation of organic matter in Middle Cretaceous Greenhorn Formation, Pueblo, Colorado: AAPG Bulletin, v. 68, p. 1146-1159.

Reinhardt, P., 1966, Zur Taxionomie und Biostratigraphie des fossilen Nannoplanktons aus dem Malm, der Kreide und dem Alttertiaer Mitteleuropas. Taxonomy and biostratigraphy of Malm, Cretaceous, and early Tertiary nannoplanktonic faunas of central Europe: Freiberger Forschungshefte, Reihe C: Geowissenschaften, Mineralogie-Geochemie, v. 196, p. 5-61.

Sageman, B.B., Meyers, S.R., and Arthur, M.A., 2006, Orbital time scale and new Cisotope record for Cenomanian-Turonian boundary stratotype: Geology, v. 34, p. $125-128$.

Schwarzacher, W., 1993, Cyclostratigraphy and the Milankovitch Theory: Amsterdam, Elsevier, p. 225. 
Sissingh, W., 1977, Biostratigraphy of Cretaceous calcareous nannoplankton: Geologie en Minjbouw, v. 56, p. 37-65.

Weedon, G.P., 2003, Time-series Analysis and Cyclostratigraphy: examining the stratigraphic record of environmental cycles: Cambridge, Cambridge University Press, p. 259.

Zhou, L. and Longoria, J.F., 1996, Milankovitch cyclicity in the Agua Nueva Formation (Cretaceous) of Northeast Mexico; a review of methodology, procedures and practice in cyclostratigraphy: Boletin del Departamento de Geologia Uni-Son, v. 13, p. 35-96. 


\section{CHAPTER X}

\section{GENERAL CONCLUSIONS}

The major objective of this work was to understand the stratigraphy of the Indidura Formation through the use of petrography, geochemistry and biostratigraphy. The results also contribute to further our understanding of the controlling mechanisms of the various orders of sedimentary cycles in the sequence, as well as the paleoenvironmental conditions conducive to $\mathrm{C}_{\mathrm{org}}$-rich events.

Thus, the present work includes the following achievements:

- I have demonstrated for the first time that cyanobacterial induced microspheroids are major contributors to a sedimentary sequence of the Cenomanian/Turonian at Parras de la Fuente, in northeastern Mexico. I described and characterized the morphology of these bacterial remains thru the use of Scanning Electron Microscopy (SEM) and standard petrographic techniques.

- In addition, I have also correlated the primary sedimentary structures found in the highly laminated marly calcilutites of the Indidura Formation with recurring perennial blooms of calcifying cyanobacteria that prevailed throughout the sequence over a period of about 4 million years. Furthermore, biomarker analysis indicates that low molecular weight $\mathrm{n}$-alkanes are the predominant compounds found in the organic matter, which implies that the bulk of the organic matter had a prokaryotic origin. 
- A net lithological difference exists between the sedimentary sequence of the Indidura Formation at the Sierra de Parras and the facies present at the stratotype section of Las Delicias and the Mexican type section of the Cañon La Casita. Large compositional differences thus indicate marked paleoenvironmental differences even though the sediments accumulated in a relatively stable carbonate platform, hence the prevailing conditions were far from uniform.

- Biostratigraphic nannofossil zonation of Indidura Formation at Parras de la Fuente further permits a better resolution of the studied stratigraphic sequence. The lithologic interval here described corresponds to the uppermost part of the Upper Cenomanian through the Middle Turonian, and to the calcareous nannofossil zones CC10 thru CC13 respectively.

- Rocks of the Indidura Formation were deposited in a paleoenvironmental setting that allowed accumulation and preservation of organic matter. Sediments have an average TOC of about $1.6 \%$ with values ranging from 0.1 to $3.6 \%$. TOC enrichment, together with the absence of benthic macro and microfossils, no apparent bioperturbation, and almost complete preservation of primary sedimentary structures denotes deposits of the Indidura Formation at Parras de la Fuente under constant low oxygen conditions (anoxic/dysoxic) that prevailed during most of the deposition of the unit. Pristane/Phytane ratios $<1$ further corroborate this interpretation. 
- Geochemical analyses $\left(\delta^{13} \mathrm{C}\right.$, major-minor and trace elements, $\mathrm{TOC} / \mathrm{CaCO}_{3}$ and Biomarkers) confirm that rocks of the Indidura Formation at Parras accumulated at times of worldwide perturbations on the carbon cycle as seen in the $\approx 2 \%$ changes of $\delta^{13} \mathrm{C}$, enrichment of $\mathrm{V}, \mathrm{Cr}$, and Mo, compared with typical marlstones and limestones. I interpret such anomalies as being related to the major paleoceanographic and paleoclimatic changes that took place before, during and after OAE2. These changes coincide with times of emplacement of Large Igneous Provinces (LIP's), and increased continental runoff during greenhouse conditions, both of which increased nutrients in the world oceans. The changes consequently caused enhanced paleoproductivity, which in turn further reduced the oxygen content in the oceans. The net effect of such paleoenvironmental perturbations on the paleo-Parras de la Fuente basin was to favor perennial blooms of calcifying cyanobacteria almost at the exclusion of other organisms.

- Decadal and millennial scales variations characterize the temporal patterns of the Indidura Formation at Parras de la Fuente. The large-scale sedimentary patterns observed in the field can be correlated with Milankovitch precession cycles of ca. 20 ka. Despite significant temporal variations, the productivity of cyanobacteria-induced calcareous microspheroids remained prevalent because of low sediment supply to the basin and poor exchange of nutrients through the water column. At the microscopicscale, laminae represent shorter-term climatic variability. I correlate such variations with the 10 to 15 year pulses of sun activity, and I further interpret the situation to be comparable to periods of increased pluviosity at the decadal scale. Large supply of 
nutrients coming from riverine runoff generated periods of normal productivity responsible for the accumulation of black laminae that also include protists such as foraminifera and radiolaria. By contrast, when conditions returned to low nutrients, productivity of calcareous cyanobacteria took over the environment again and light laminae rich in microspheroids were accumulated. 


\section{VITA}

\section{FABIAN DUQUE-BOTERO}

\section{EDUCATION}

- Geologist Degree, B.Sc. (Honors Equivalent) Universidad Nacional de Colombia, Bogotá, Colombia. Spring 2000.

\section{TEACHING EXPERIENCE}

- 2001-2005: History of life laboratory, Department of Earth Sciences, Florida International University, Miami, Florida.

- 2001, 2002, 2003: Introduction to Earth Sciences laboratory, Department of Earth Sciences, Florida International University, Miami, Florida.

- 2002, 2003, 2004: Stratigraphy laboratory, Department of Earth Sciences, Florida International University, Miami, Florida.

- 1997-1998: Sedimentology laboratory, Departamento de Ciencias de la Tierra, Universidad Nacional de Colombia, Bogotá, Colombia.

\section{AWARDS AND HONORS}

- 2006: Dissertation Year Fellowship, Florida International University, Miami, Florida.

- 2005, 2003, 2002: Travel grant, Graduate Student Association, Florida International University.

- 2005: Travel grant to the $7^{\text {th }}$ International symposium of the Cretaceous, Neuchatel, Switzerland.

- 2003: Travel grant to Bioevents, Caravaca de la Cruz, Spain.

- 2003, 2002: Travel grant, Geological Society of America.

\section{PUBLICATIONS, POSTERS AND PRESENTATIONS}

- Duque-Botero, F. and Maurrasse, F., 2005, Cyanobacterial productivity, variations in the organic matter and facies of the Indidura Formation (Cenomanian-Turonian), Northeastern Mexico, Journal of Iberian Geology, 31: pp. 85-98.

- Duque-Botero, F. and Maurrasse, F., (Submitted to Cretaceous Research), Role of cyanobacteria in $\mathrm{C}_{\text {org }}$-rich Deposits: an example from the Indidura Formation (Cenomanian-Turonian), northeastern Mexico.

- Duque-Botero, F., Maurrasse, F., Hickey-Vargas, R., Melinte, M.C., Jaffe, R. and Lopez Oliva, J.G., (Submitted to SEPM Special Publication), Microspheroid accumulation and geochemistry of an anoxic basin of the Cenomanian/Turonian: The record of the Indidura Formation, NE Mexico

- Duque-Botero, F., Maurrasse, F. and Melinte, M.C., (Submitted to Earth and Planetary Science Letters), Cyclic sedimentation from the Cenomanian/Turonian of NE Mexico: its relationship to Milankovitch and solar cycles. 
- Duque-Botero F. and Maurrasse F. 2005, Calcareous cyanobacterial microspheroids from the Cenomanian/Turonian of the Indidura Formation, NE Mexico, 7th International Symposium on the Cretaceous, Neuchatel, Sept 8, 2005. (Poster).

- Duque-Botero F. and Maurrasse F. 2005, Organic rich black shales and laminated limestones of the Indidura Formation (C/T) NE Mexico: the role of cyanobacteria in their genesis, American Association of Petroleum Geologists Student Expo, Houston, Oct 7-8 2005. (Poster).

- Duque-Botero F. and Maurrasse F. 2005, Cyanobacterial Productivity, Variations in the Organic Matter and Facies of the Indidura Formation (Cenomanian-Turonian), NE Mexico, Abstracts Volume with Programs, Geologic Problem solving with Microfossils, March 2005, p33.

- Duque-Botero, F and Maurrasse, F.J.M-R., 2003, Organic rich Sediments of the Indidura Formation (C/T?), northeastern Mexico. Geological Society of America Abstracts with Programs, Vol. 35, No. 6, September 2003, p. 87. (Poster).

- Duque-Botero, F and Maurrasse, F.J.M., 2003, Variations on the $\mathrm{C}_{\text {org }}$ and facies of the Indidura Formation (Cenomanian-Turonian), northeastern Mexico, BIOEVENTS: their stratigraphical records, patterns, and causes, Caravaca de la Cruz, Spain, Abstract. (Poster).

- Duque-Botero, F. and Maurrasse, F. J. M., 2002, Spatial and Temporal Variations of the Indidura Formation (Cenomanian-Turonian) in Northeastern Mexico, Coahuila State, Eos Trans. AGU, 83(47), Fall Meeting Supplement, Abstract PP11A-0306. (Poster).

- Duque-Botero, F. and Maurrasse, F. J. M., 2002, Microbial (cyanobacteria?) induced sediments from the Cretaceous of northeastern Mexico, Abstracts with Programs Geological Society of America, 34(6), p.16. (Poster).

- Duque-Botero, F. and Maurrasse, F., (April 17, 2006), Stratigraphy of the Indidura Fm., NE Mexico: the record of a Cretaceous anoxic basin, Presented at University of Miami RSMAS-Geology Seminar Series, Miami FL. (Invited Presentation).

- Duque-Botero, F. and Maurrasse, F., (March, 2005), Cyanobacterial Productivity, Variations in the Organic Matter and Facies of the Indidura Formation (CenomanianTuronian), NE Mexico, Presented at Geologic Problem solving with Microfossils, Houston Texas. (Presentation). 